
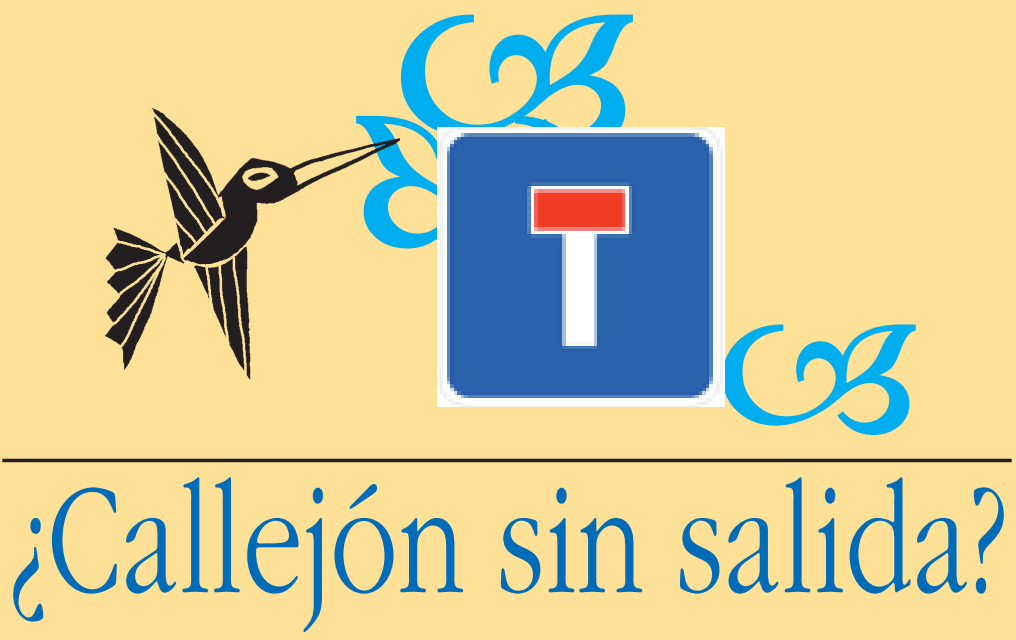

La crisis ecológica en la poesía bispanoamericana 

¿CALLEJÓN SIN SALIDA?

La crisis ecológica en la poesía hispanoamericana 



\title{
¿CALLEJÓN SIN SALIDA? \\ La crisis ecológica en la poesía hispanoamericana
}

\author{
Niall Binns
}




\section{FICHA CATALOGRÁFICA}

BINNS, Niall

¿Callejón sin salida? : la crisis ecológica en la poesía hispanoamericana /

Niall Binns. — Zaragoza : Prensas Universitarias de Zaragoza, 2004

187 p. ; $22 \mathrm{~cm}$. - (Humanidades ; 46)

ISBN 84-7733-693-8

1. Medio ambiente. 2. Poesía hispanoamericana-S. XX. I. Prensas Universitarias de Zaragoza. II. Título. III. Serie: Humanidades (Prensas Universitarias de Zaragoza) ; 46

504.03:821.134.2(7/8)-1«19»

No está permitida la reproducción total o parcial de este libro, ni su tratamiento informático, ni la transmisión de ninguna forma o por cualquier medio, ya sea electrónico, mecánico, por fotocopia, por registro u otros métodos, ni su préstamo, alquiler o cualquier forma de cesión de uso del ejemplar, sin el permiso previo y por escrito de los titulares del Copyright.

(C) Niall Binns

(C) De la presente edición, Prensas Universitarias de Zaragoza

$1 .^{\text {a }}$ edición, 2004

Ilustración de la cubierta: José Luis Cano

Colección Humanidades, n. ${ }^{\circ} 46$

Directora de la colección: Rosa Pellicer Domingo

Editado por Prensas Universitarias de Zaragoza

Edificio de Ciencias Geológicas

C/ Pedro Cerbuna, 12

50009 Zaragoza, España

Prensas Universitarias de Zaragoza es la editorial de la Universidad de Zaragoza, que edita e imprime libros desde su fundación en 1542.

Impreso en España

Imprime: Litocián, s.l.

D.L.: Z-917-2004 
Para Vanesa 



\section{CAPÍTULO 1. DESDE EL ECOLOGISMO HACIA UNA ECOCRÍTICA}

\section{El hombre contra los bosques}

Desde el descubrimiento del fuego, desde la primera rudimentaria práctica de la agricultura y la ganadería, el ser humano ha sido un contaminador en potencia, una especie sobrenatural en su capacidad de modificar su entorno y sobrepasar los «límites» naturales. Robert Pogue Harrison empieza su libro Forests con una cita del ilustrado italiano Giambattista Vico: «Éste fue el orden de las instituciones humanas: primero los bosques, después las chozas, luego los pueblos, entonces las ciudades, y por último las academias (1992: 15). En efecto, la civilización ha sido siempre una batalla contra los bosques, un abrirse paso y espacio entre los árboles y un progresivo alejamiento de ellos. La deforestación es una parte intrínseca del desarrollo de los imperios, y ha sido practicada para construir una armada, la muralla maritima, en el caso de Atenas y Venecia y por motivos agrícolas en Roma y en tantos países «subdesarrollados» de hoy. El precio de la expansión es la desertización y Pogue Harrison cita unas palabras de Platón sobre los cerros del Ática como indicio de una precoz reacción al deterioro ecológico: «En comparación con lo que entonces había, sólo quedan los huesos del cuerpo consumido [...]. Todas las partes más ricas y blandas del suelo se han escurrido, y permanece el mero esqueleto de la tierra. Pero en el estado primitivo del campo, sus montañas eran cerros altos cubiertos de humus [...] y hubo leña abundante en los montes» (55). 
Pero el bosque desaparece también, en tierras colonizadas por el imperio de turno, porque constituye una amenaza, un depositario de valores autónomos, de los mitos y relatos fundacionales del lugar que la potencia colonizadora necesita anular para mejor dominar: «Los bosques eran obstáculos para la conquista, la hegemonía y la homogeneización. Eran, en una palabra, asilos de independencia cultural» (51). Así, deforestar significa desarraigar y desamparar a una comunidad, dejarla a la merced universalizadora del invasor.

La noción del bosque como lugar de arraigo existe todavía. Si la deforestación sigue siendo un "problema» ecológico que nos conmueve, esto no tiene tanto que ver, afirma Pogue Harrison, con nuestra preocupación racional por la pérdida de la naturaleza, ni mucho menos por nociones tan intangibles como el empobrecimiento de la biodiversidad o la regulación climática, sino, a un nivel mucho más profundo, con nuestra angustia por la pérdida de las «memorias no contadas, los antiguos temores y sueños, las tradiciones populares, y los mitos y símbolos más recientes [que] están ardiendo en los fuegos de la deforestación» (XI). Porque la deforestación es un atentado contra nuestro espíritu, como lo es también nuestra agresión contra el aire y el mar, contra los ríos y los lagos, y la flora y la fauna, sin los cuales no podríamos vivir pero que son, a la vez, el depositario secular de la cultura. Al talar los bosques y al contaminar a la tierra, nos estamos automutilando. ${ }^{1}$

La modernidad dio alas a los sueños de poder del ser humano, convirtiéndolo en un auténtico depredador de su entorno. Frente a la visión tradicional (tanto en la Europa premoderna como en la América precolombina) de un universo orgánico y animado, de una Tierra que el hombre veneraba y respetaba, surgió el pensamiento radicalmente desacralizador de un Francis Bacon. La naturaleza dejaba de ser un ente sagrado y mágico: ahora sería puesta al servicio del capitalismo naciente, estudiada, «sometida a interrogatorio» en busca de sus secretos y dominada. René Descartes, por su parte, decretó la observación, la experimentación y la búsqueda de regularidades o leyes matemáticas en la naturaleza, cuyo funcionamiento mecánico e insensible él extendió a los animales, que no eran más que máquinas sofisticadas (Bowler, 48-71).

1 «Necesitamos el bosque, no sólo las plantaciones de árboles. Si no queremos perdernos a nosotros mismos, necesitamos el bosque» (Riechmann, 2001: 82). 
Armado con esta nueva filosofía mecanicista, el hombre de la revolución industrial se encontró, de pronto, con los medios para poner en práctica sus deseos de dominio y para organizar el despojo sistemático de la tierra, desencadenando así un deterioro ecológico enloquecido, en todas las facetas que seguimos hoy conociendo y a veces experimentando en carne propia: el (casi) agotamiento de los recursos naturales, tanto renovables (los bosques, los suelos fértiles) como no renovables (el petróleo, el carbón); la proliferación de residuos tóxicos; la contaminación del aire y del agua; el efecto invernadero; el adelgazamiento de la capa de ozono; la amenaza nuclear; la extinción de plantas y animales. Y un largo etcétera. La industrialización permitió un "progreso" material —que permitió, a su vez, una expansión demográfica antes inconcebible-, pero ha terminado por mostrarse contradictoria y autodestructora: no se puede aspirar al crecimiento infinito en un planeta que es finito en su tamaño y sus recursos.

\section{Nace el ecologismo}

Dos siglos después de la revolución industrial, el consumismo globalizado se ha instalado como el motor del mundo. El progreso se ha degradado en codicia generalizada, en un cainismo galopante (el mundo de dog-eatdog): estamos consumidos por el consumismo. Nuestros políticos siguen creyendo en un crecimiento económico (los sagrados índices del PIB) que es, sin embargo, insostenible y que condena a un empobrecimiento igualmente insostenible a los países y los sectores de la población más desprotegidos. Fueron los años sesenta los que vieron un primer auge del movimiento ecologista. En 1962, Rachel Carson publicó Silent Spring ( $L a$ primavera silenciosa), una denuncia pionera de los estragos provocados por los herbicidas y pesticidas de la industria química. En 1961 se había instituido el Fondo Mundial para la Naturaleza (WWF: World Wildlife Fund); diez años después Greenpeace fue fundado en Canadá y Amigos de la Tierra (Friends of the Earth) en California. 1972 fue un año clave, al divulgar la dimensión internacional de la crisis ecológica: la Conferencia de la ONU sobre Medio Ambiente Humano terminó con la creación del Programa de las Naciones Unidas para el Medio Ambiente, y los analistas políticos y económicos del llamado Club de Roma, encabezados por Dennis Meadows, publicaron el informe The Limits to Growth (Los limites del crecimiento), que 
avisó de los peligros de la explosión demográfica, la industrialización, la contaminación y el consumo de los recursos naturales no renovables, y sobre todo del crecimiento exponencial, y no lineal, de las amenazas:

Un puzzle francés para niños ilustra otro aspecto del crecimiento exponencial: la manera aparentemente súbita con que se acerca a un límite fijo. Supón que eres el dueño de un estanque en el que crece un nenúfar. El nenúfar se duplica en tamaño cada día. Si se le permitiera al nenúfar crecer sin controles, cubriría el estanque completamente en el curso de treinta días, asfixiando todas las otras formas de vida en el agua. Durante mucho tiempo, el nenúfar parece pequeño, así que decides no recortarlo hasta que cubra la mitad del estanque. ¿En qué día llegará ese momento? En el día veintinueve, por supuesto. Tienes un día para salvar el estanque. (Meadows, 69)

La implicación es clara: estamos en el día 30 y debemos actuar con urgencia. ${ }^{2}$ Las conclusiones del Club de Roma hicieron hincapié en que si no hubiera cambios, se alcanzaría dentro de cien años los límites del crecimiento del planeta, con una repentina e incontrolable pérdida tanto de la población como de la capacidad industrial, en vista de lo cual reclamaron un gran período de «transición desde el crecimiento hacia el equilibrio global» (24). A partir de entonces, los informes catastrofistas han avanzado in crescendo, pero una toma de conciencia ecologista requiere catástrofes experimentadas en carne propia (la cotidianidad del smog, ríos sin peces, playas contaminadas, etc.), o amenazas casi tangibles en su cercanía para poder consolidarse. Y así ocurrió en los años ochenta, cuando se empezó a hablar en términos apocalípticos del agujero en la capa de ozono, y del efecto invernadero, y de la deforestación amazónica, y de una

2 Según Francesc Muñoz Pradas, si en el año 1750 hubo 771 millones de habitantes en el planeta, la figura subió a los 2.515 millones en 1950, a 3.698 millones en 1970, y a casi 6.000 millones en la actualidad. Estos números muestran el peligro del crecimiento exponencial, porque si en 1970 una tasa de crecimiento del $2 \%$ suponía un aumento en la población mundial de 59 millones anuales, la tasa de crecimiento de un 1,73\%, computado para el quinquenio 1985-1990, supone aproximadamente 80 millones de nuevos seres humanos cada año; y en la Conferencia sobre Población y Desarrollo, celebrada en El Cairo en 1994, se estimó que la población mundial llegaría a 10.000 millones antes del año 2050. Dice Muñoz Pradas: "Vivir dentro de la onda expansiva de la "explosión demográfica" es algo semejante a viajar en el interior de un automóvil sometido a un notable efecto de inercia. Aunque haya iniciado la maniobra de frenado, su velocidad no disminuye proporcionalmente, alimentada por su aceleración anterior» (1996: 64-65). 
tercera guerra mundial, y del desastre de Chernóbil. ${ }^{3}$ Nacieron grandes campañas populares en contra de la energía y el armamento nucleares y en defensa de la ballena, las focas y los osos pandas, y las ONG ecologistas y partidos políticos como los Verdes alemanes crecieron notablemente.

Quizá el evento más importante de la última década — sobre todo al nivel simbólico de las buenas intenciones-, haya sido la Conferencia de las Naciones Unidas sobre Medio Ambiente y Desarrollo, celebrada en Río de Janeiro en 1992 con la asistencia de representantes oficiales de 153 países, entre ellos 118 jefes de gobierno. No se llegó, sin embargo, a grandes conclusiones y la Agenda XXI no fue planteada como un texto jurídicamente vinculante. Su financiación, que tendría que ser aportada por los países ricos a costa del $0,7 \%$ de su PIB, ha sido un fracaso vergonzoso. Conviene recordar, como Jorge Riechmann, que cuando el presidente Bush (senior) subió al avión que lo llevaría a la Conferencia, anunció que «nuestro modo de vida no puede ser objeto de negociaciones». Riechmann contrapone a estas palabras otras de Gandhi — «la tierra brinda lo suficiente para satisfacer las necesidades de todos, pero no la codicia de todos»— y señala: «si el American way of life - y el European, y el Japanese way of life - no pueden ser cuestionados, entonces no existe ninguna posibilidad de paliar los espantosos daños que están causando la crisis ecológica global y el ahondamiento del abismo Norte-Sur» (1998: 5-8).

\section{El ecologismo en Latinoamérica}

En el artículo «La ecología en el marco de la impunidad», Eduardo Galeano presenta un retrato terrorífico de la degradación ecológica en la América Latina, donde la «lógica económica» del neoimperialismo campea y contamina a sus anchas; donde «la energía es barata y el medio ambiente sufre en silencio»; donde, "atraídas por los salarios enanos y la libertad de

3 Fernando Mires habla de una «nueva sensibilidad» ecológica que tendría que ver con la conciencia de los riesgos de un posible segundo Chernóbil, de vivir en el aire envenenado de las ciudades industrializadas, de los viajes «en carreteras atestadas y plagadas de cadáveres», y de "simplemente tomar el sol en alguna playa (ya que bañarse en el mar es una aventura que pertenece al pasado)»: los rayos del sol «desprovistos de protección ozónica constituyen la mejor garantía para morir de cáncer» (1996: 21). 
contaminación», las corporaciones norteamericanas emigran al sur de la frontera mexicana; donde los monocultivos esquilman y empobrecen: mientras Colombia cría tulipanes para Holanda y rosas para Alemania, "Holanda recibe los tulipanes, Alemania recibe las rosas y Colombia se queda con los bajos salarios, la tierra lastimada y el agua disminuida y envenenada»; y donde se sufre en carne propia las agresiones contra el medio ambiente:

Impunemente, la Bayer y la Dow Chemical producen y venden, en América Latina, fertilizantes y pesticidas prohibidos en Alemania y Estados Unidos. Impunemente, la Volkswagen y la Ford producen y venden automóviles sin los filtros que son obligatorios en Alemania y Estados Unidos. Más de doscientos plaguicidas que figuran en la lista negra de la Organización Mundial de la Salud, se utilizan en Uruguay, que es uno de los países con más cáncer en el mundo. Los habitantes de la ciudad de México tienen la más alta concentración de plomo en la sangre; las indígenas que trabajan en las plantaciones de la Costa de Guatemala dan de mamar la leche más intoxicada del planeta. (1996: 55-58)

Fiel a su perspectiva marxista, Galeano denuncia la responsabilidad del neocolonialismo económico en la degradación ambiental. Existe en Hispanoamérica, sin embargo, lo que Fernando Mires ha llamado "la coartada de la dependencia», la tendencia de echar toda la culpa por los daños económicos y ecológicos a los imperialismos extranjeros, y de ocultar las responsabilidades nacionales y locales. Mires enuncia las coartadas, propias de lo que llama el «subdesarrollo ecológico» de Latinoamérica. Se suele decir, por ejemplo, que el ecologismo es un lujo, un problema de país rico; los pobres, en cambio, deben preocuparse por el hambre y la miseria. Y sin embargo, "la devastación de la naturaleza produce hambre y miseria». Son temas inseparables. Otros dicen que «las ideologías con inspiración ecológica, son parte de una maniobra de los países «imperialistas» a fin de impedir el pleno desarrollo de los países pobres»; es decir, que ellos han disfrutado de los beneficios económicos de la deforestación y ahora — los muy hipócritas - quieren impedir que nosotros logremos los mismos beneficios. Con este argumento los gobiernos brasileños, por ejemplo, se han opuesto a la «internacionalización» de la defensa de la Amazonia; pero Mires insiste en que son los indígenas y los campesinos del país los que más sufren de la deforestación y se pregunta, además, hasta qué punto ésta beneficia a los gobiernos nacionales: «si bien es cierto que la deforestación de la Amazonia ha desatado una masiva protesta interna- 
cional, mucho más internacionales son las empresas que están imbricadas». Por último, menciona una tercera "coartada», opuesta a la anterior, según la cual el imperialismo sería el responsable de todos los problemas ecológicos de Latinoamérica. Esto lleva, según Mires, a la resignación, y a la vez oculta el colonialismo interior, la especie de apartheid que impera en muchos países: «Que la cultura dominante en América Latina no sólo sea antiecológica sino que, en muchos sentidos, racista, dista de ser una casualidad. Lo uno lleva a lo otro. No se puede dividir la naturaleza de un país, sin hacerlo con sus habitantes» (1990: 63-66).

Si la deforestación es el gran problema ecológico de Latinoamérica, capaz de suscitar protestas internacionales, es también un problema íntimamente vinculado con la supervivencia de las poblaciones indígenas, que han vivido desde antes de la Conquista una relación infinitamente más armónica con su entorno que la de los invasores y de las sociedades que éstos impusieron. De hecho, como han señalado últimamente investigadores como Alfred Crosby (1988) y Elinor Melville (1994), la crisis ecológica empezó en América con la llegada de los españoles. Lo han dicho también, en el contexto argentino, Brailovsky y Foguelman: «La historia ambiental de la Argentina se inicia con una de las catástrofes ecológicas más serias que hayan ocurrido en el país: la destrucción del sistema incaico de agricultura en terrazas, perpetrada por los conquistadores españoles» (1990: 26). Así, la crisis ecológica es inseparable de la crisis étnica y la historia latinoamericana de la resistencia contra la conquista, la colonia y el neoimperialismo económico ha sido siempre, en el fondo, una larga lucha contra el etnocidio y el ecocidio:

Hace quinientos años [...] que los más legítimos habitantes de América vienen luchando por el respeto a sus condiciones de existencia y por la defensa de los fundamentos naturales de su reproducción cultural y económica. ¿Por qué lucharon los indios-campesinos de Emiliano Zapata, contra Díaz, Madero, Huerta, Carranza y contra quien se les pusiera por delante, sino por la defensa del "ejido", unidad de reproducción social comunitaria y ecológica? ¿Por qué lucharon los indios peruanos y bolivianos desde Tupac Amaru hasta nuestros días, sino por la recuperación del ayllu basado en la reciprocidad entre seres humanos y la naturaleza? ¿Por qué lucharon los indios miskitos frente a los modernizadores revolucionarios sandinistas, sino por la defensa de su medio ambiente natural? ¿Por qué luchan los pueblos amazónicos, sino para evitar que la Amazonia sea convertida por las grandes empresas en un desierto? ¿Por qué hoy en día los pueblos indios ecuatorianos se organizan políticamente, sino para defender sus tierras? No. No es cierto que los temas ecológi- 
cos sean muy nuevos en América latina. La resistencia ecológica tiene en nuestro continente muchos años. Lo que sucede es que la lectura de "la historia oficial» nos ha impedido reconocer a sus actores. Y los representantes de esa «historia oficial» tienen también sus motivos: reconocer a los actores de la razón ecológica, vale decir, a los defensores más inmediatos de la naturaleza, implicaría revisar el estrecho concepto de nación y de sociedad que ellos poseen. En el fondo, no temen a la ecología; temen a sus representantes, a quienes con sus incompetentes análisis han condenado al silencio. (Mires, 1996: 37)

\section{La ecocrítica: ¿otra moda más en las aulas?}

En su escandalosa elegía por el canon extraviado, The Western Canon (1995), Harold Bloom vuelve a arremeter contra lo que a él le place llamar la "Escuela del Resentimiento", es decir, los críticos y profesores marxistas, feministas, afrocentristas, neohistoricistas y deconstructivistas (etc.) que llenan revistas literarias y programas universitarios con criterios basados más en sus preocupaciones sociales que en la "calidad estética» de las obras. No me cabe duda de que Bloom, acaso el único best-seller entre los críticos literarios del planeta, se habrá vuelto a exasperar ahora que en el mundo académico anglosajón surge una nueva tendencia para engrosar el conjunto de ismos que él tanto denuesta. Se llama ecocriticism: una crítica literaria ecológica; una ecocrítica.

«La ecocrítica es el estudio de las relaciones entre la literatura y el medio ambiente», dice Cheryll Glotfelty en su introducción a The Ecocriticism Reader (1996: XVIII) — hasta ahora el texto medular sobre el tema-, y centenares de críticos están hoy trabajando en esta línea forzosamente interdisciplinar, fieles a la premisa ecológica de que todo está conectado a todo y confiados en la certeza de que pretender desvincular la calidad estética de una obra de su contexto (socioeconómico, político pero también ecológico) es simplemente una simpleza de Bloom y Cía. Según Glotfelty, los ecocríticos y teóricos plantean preguntas como las siguientes:

¿Cómo se representa la naturaleza en este soneto? ¿Qué papel desempeña el espacio en la trama de esta novela? ¿Son compatibles los valores expresados en esta obra con la sabiduría ecológica? ¿Qué influencia tienen nuestras metáforas de la tierra en la forma en que la tratamos? [...] ¿En adición a raza, clase y género, debería lugar convertirse en una nueva categoría crítica? ¿Los hombres y las mujeres escriben sobre la naturaleza de manera 
diferente? ¿De qué manera afecta la alfabetización la relación entre el hombre y el mundo natural? ¿Cómo y con qué efecto se va introduciendo la crisis ambiental en la literatura contemporánea y en la cultura popular? [...] ¿Qué repercusiones podría tener la ciencia de la ecología en los estudios literarios? ¿De qué manera está abierta la ciencia al análisis literario? ¿Qué transfecundación puede haber entre los estudios literarios y el discurso ambiental en disciplinas cercanas como la historia, la filosofía, la psicología, la historia del arte y la ética? (XVIII-XIX)

Glotfelty afirma que el desarrollo de la ecocrítica sigue (o seguirá) las mismas etapas señaladas por Elaine Showalter en su prólogo a The New Feminist Criticism, un estudio clásico sobre la evolución del feminismo: primero, una búsqueda de imágenes de la naturaleza [en el feminismo, claro, imágenes de mujeres] en la literatura canónica, identificando los estereotipos (Edén, Arcadia, etc.) y las ausencias significativas; en un segundo momento, el rescate de la tradición secreta de textos escritos desde la naturaleza [la analogía resulta un tanto coja: hay una tradición marginal de mujeres que escriben, pero el canto de la tierra, de ruiseñores y ballenas, no es exactamente literatura; y aunque el ser humano intente representar la tierra o convertirse en su portavoz, nunca la encarnará]; ${ }^{4}$ por último, la fase teórica, preocupada por las construcciones literarias del ser humano en relación con su entorno natural [de la mujer en relación con el entorno patriarcal] y por formular poéticas ecológicas desde las diversas posturas de la ecología profunda, el ecofeminismo, etc. (XXII-XXIV).

Como el feminismo y el marxismo, el enfoque ecocrítico implica romper con nociones de la autonomía del texto literario y volver a examinar las relaciones entre la obra y su entorno, y como ellos tiende inevitablemente hacia cierto activismo, hacia un despertar de la conciencia y por tanto la denuncia de un mundo inaceptable en sus abusos. Como suele ocurrir en los movimientos embrionarios, sobre todo si son movimientos militantes, ha brotado una plaga de estudios ecocríticos fáciles, facilones y

4 Jonathan Bate reconoce esta desventaja para la ecocrítica con respecto al feminismo y los estudios post-coloniales. Una mujer puede hablar de la histórica marginación de su género y un africano o asiático de la colonización y saqueo de su cultura de origen. En cambio, «el ecocrítico no tiene más opción que la de hablar en nombre del Otro. [...] Un crítico puede hablar como mujer o como persona de color, pero no puede hablar como árbol» (2000: 72). 
empobrecedores; pero hay también, me parece, una serie de enfoques nuevos bastante interesantes y un puñado de ecocríticos (notablemente, yo diría, Jonathan Bate y Lawrence Buell) tan sensibles como lúcidos.

\section{Atrapado en una red: el adelgazamiento del yo}

La visión ecológica del mundo rompe dramáticamente con la idea moderna del ser humano como individuo autónomo y centro del universo. Participa, en este sentido, de la noción postmoderna de una fragmentación o adelgazamiento del ser humano, y concuerda con la imagen sugerente de Foucault, del hombre como «una invención reciente» —es decir, moderna, nacida acaso con Descartes, acaso a finales del siglo XVIII - que estaría a punto de borrarse, "como en los límites del mar un rostro de arena» (1991: 375). Porque el hombre como ser autónomo se hace insostenible, desde una perspectiva ecológica, al darse cuenta de que la vida es una inmensa red de interconexiones e interdependencias. Por eso, Buell ve como una pulsión básica de la literatura ecológica el camino que la lleva desde el antropocentrismo y el egocentrismo modernos hacia un nuevo ecocentrismo, en el que el yo dejaría de percibirse como superior a su entorno. Al reformular las relaciones entre el yo y su entorno, Buell examina el concepto de una «estética de la renuncia», un aesthetics of relinquishment que existiría en esos autores que persiguen una «literatura de la sencillez voluntaria», en que el narrador, el hablante o los personajes renuncian a los bienes materiales. Pero esta estética puede llevar también, de manera más radical, a una renuncia del yo a la autonomía individual (1995: 143-144); a un dejarse permear por lo otro o un metamorfosearse en otros yoes (166); a una personificación de animales y plantas que atenúa los abismos jerárquicos entre homo sapiens y las demás especies (180), y a un retorno a las formas míticas y animistas del pasado (204).

\section{El lugar de la tradición o la tradición del lugar}

Al perder sus ilusiones de autonomía, el ser humano empieza a investigar la índole de las relaciones que le permiten vivir y que le otorgan su identidad. Somos seres situados, aunque la modernidad se haya negado a reco- 
nocerlo: ser siempre es estar. Ver el entorno como una especie de espacio despersonalizado es sucumbir a la trampa y la condena de lo moderno: vivir en el desarraigo y la alienación. Formar parte de un lugar, o de varios lugares, significa, en cambio, habitar un espacio cargado de significación, de particularidad y de valor (Buell, 2001: 59). Restablecer las conexiones con los lugares, sin caer en un conservadurismo reaccionario, es un desafío fundamental para las sociedades contemporáneas y también para la poesía.

El primer paso poético podría consistir en una vuelta a la mirada atenta promovida por los románticos ingleses, a la «atención vivificadora» que comparten el arte y la ciencia (Elder, 166), o a lo que José Emilio Pacheco ha llamado la «atención enfocada»: hay que abrir nuestros ojos y todos los sentidos a lo nuevo y a lo viejo, recordar que la poesía, como los seres humanos, está siempre situada, y por lo tanto indagar en la relación de sus raíces. Esta mirada puede conducir a una poesía localista —el regionalismo interesa a muchos ecocríticos- y un interés por lo pequeño, por el detalle; pero también podrá ir por debajo y más allá de las superficies. Esto no significa, desde luego, una carencia. Tal vez valga la pena recordar las palabras de Rilke: «Si su vida cotidiana le parece pobre, no se queje de ella; quéjese de usted mismo, dígase que no es bastante poeta como para conjurar sus riquezas: pues para los creadores no hay pobreza ni lugar pobre e indiferente» (1999: 23). Cada lugar, por pobre e indiferente que parezca, es inmenso en la profundidad de su historia particular y en la red de relaciones que emerge de él.

El ecologismo promueve una vuelta al lugar como un contrapunto al desarraigo y a la «urbanización patológica» (Alameda Ospina, 90) de nuestro mundo, que incide no sólo en los habitantes sino hasta en la tradición poética del lugar. En efecto, no se puede separar cultura y naturaleza, ${ }^{5}$ por-

5 La dicotomía entre naturaleza y cultura es, como siempre, problemática. Aunque a veces parezca referirme a aquélla como un espacio más o menos libre de la impronta humana, prefiero seguir a Jorge Riechmann cuando define la naturaleza "como biosfera, como sistema organizado de los ecosistemas» (1997: 7). El ser humano se porta de manera anti-natural cuando viola los procesos cíclicos de la biosfera y vulnera la sustentabilidad del sistema, y es en este sentido que una economía agraria resulta más "natural» que una industrial (18-19). Sólo en este contexto de comportamiento "anti-natural» podría llegarse a plantear una dicotomía tajante entre cultura y naturaleza o civilización y barbarie. En otros momentos del libro me referiré a la naturaleza no humana para destacar que estoy deliberadamente excluyendo a los seres humanos. 
que aquélla es siempre el producto de la vivencia particular de un lugar: «la poesía, como la flora y fauna de un ecosistema, es una manifestación del paisaje y del clima» (Elder, 39). En esta línea, el poeta y ecologista norteamericano, Gary Snyder, ha comparado la tradición cultural de un lugar determinado con el proceso cíclico de descomposición y putrefacción de un ecosistema "en estado de clímax». Los poetas surgen, como hongos que brotan de la biomasa muerta del suelo, desde el detritus de los símbolos y las imágenes, de la memoria y las experiencias y las obras de la comunidad; los textos se descomponen y vuelven a recomponerse, en un proceso ininterrumpido de reciclaje (Elder, 31; 177). El poeta chileno Eduardo Llanos, cuyos ensayos muestran siempre una voluntad integradora y fraternal respecto a la tradición, ha representado este concepto orgánico de la tradición en un memorable poema visual (ver página 21), el ideograma de un árbol donde el respeto por "cada rama toda hoja cada hija todo nudo» del tronco es el punto de partida para arraigar la poesía en su ecosistema cultural.

En esta misma línea, en un texto pionero de ecocrítica hispana, La Ecología Literaria como responsabilidad del escritor, Joaquín Marta Sosa denuncia la literatura dominante en Hispanoamérica como producto y productora del envenenamiento del ecosistema humano: es una literatura de la polución, una literatura smog, dependiente de tendencias literarias que proceden de los países industrializados (el surrealismo, el estructuralismo, el realismo socialista, etc.), más interesada por el «verbismo» narcisista que por la comunicación con el lector, e indiferente hacia las realidades sociales (1989: 4-6). Marta Sosa reclama, en cambio, una literatura «ecológica» que ponga el énfasis en la comunicación, en los temas candentes de la actualidad americana y en la relación de la literatura con la sociedad. Esta nueva escritura tendría la función liberadora de «limpiar de incomunicación y escoria formal-elitista y neutralista a nuestra literatura para que ella pase de tránsito del coloniaje a vía que contribuye a la liberación», y de ayudar a fundar un nuevo ecosistema en Hispanoamérica. En fin, se trata de buscar una literatura del estar (la que incorpora la existencia concreta y hacia ella se dirige; la que se nutre de la totalidad concreta y no de la neutralidad abstracta), en vez de la literatura del ser, metafísica, experimental, preocupada con idealidades y "esencialismos irreales», y radicalmente desarraigada (10). Un ejemplo del «realismo integrador» que él solicita se encuentra, según Marta Sosa, en la literatura testimonial y en los talleres de poesía promovidos por Ernesto Cardenal en la Nicaragua sandinista (11). 
«Árbol genealógico», de Eduardo Llanos Melussa

\author{
heme \\ pues aquí \\ soy el frondoso \\ árbol genealógico
}

de toda poesía vieja o nueva

sea adánica edénica o satánica

algunas de mis hojas caen es cierto

pero esponjan la tierra se hacen abono

mis mejores frutos estallan sobre las cabezas

de quienes se van por las ramas ramoneando

o de quienes dormitan y roncan bajo mi sombra

la verde verdad de mi follaje busca más y más cielo

por eso mis raíces se hunden en el subsuelo

acepto riegos y podas mis pájaros cantan

me olvido de esos que acuchillan mi corteza

borro sus nombres mientras voy creciendo

me asustan los hacheros que cumplen

órdenes municipales o ministeriales

¿qué daño hago yo a nadie?

A TI QUE MIRAS

TE RUEGO

RESPETAR

Y AMAR

CADA

RAMA

TODA

HOJA

CADA

HIJA

TODO

NUDO

DE MI

TRONCO

Y POR FAVOR

NUNCA ORINES

AQUÍ EN MIS RAÍCES

(Llanos, 2003: 102) 
Más allá de sus esquematismos, esta perspectiva resulta estimulante no sólo por su precocidad ecocrítica, sino por el hincapié que hace en una literatura del estar y por su insistencia en una relación vinculante entre la contaminación atmosférica de un lugar y la paralela contaminación de sus habitantes. ${ }^{6}$ Sin embargo, los maniqueísmos hacen agua. Frente a una invasión de especies foráneas, un ecosistema en estado de clímax —que nunca es estático, sino más bien un proceso dinámico de gran flexibilidad- tiene enorme capacidad de adaptarse para integrar lo ajeno en sus ciclos o bien, si la integración resulta imposible, de expulsarlo. Del mismo modo, el ecosistema de Snyder y el árbol de Llanos son perfectamente capaces de incorporar lecturas foráneas. Lo peligroso - ecopoéticamente- sería derribar el árbol de la tradición e intentar empezar desde cero: de ahí surgiría una poesía de desarraigo, la poesía de smog que denuncia Marta Sosa.

\section{El lugar sacralizado: un regreso a la Edad de Oro}

Las fuerzas centrípetas de la modernidad han impulsado a millones de personas a abandonar sus provincias y amontonarse en las grandes urbes, a incorporarse al espacio del progreso. Pero el progreso, esa sensación moderna de estar viviendo o al menos forjando el futuro, conlleva la cara inversa de la nostalgia, de la conciencia del desarraigo. La nostalgia dora los recuerdos y los sacraliza: el lugar abandonado se reconstruye como morada, como

6 Compárese esta idea de Pogue Harrison: «si la desertización ocurre por dentro, los bosques no podrán sobrevivir por fuera. El alma y el hábitat — por fin estamos en una posición de saberlo- son correlatos uno del otro». De ahí la importancia de la figura de la tierra baldía en la literatura moderna: al explicar su célebre poema como un testimonio de su desesperanza personal frente a la decadencia espiritual de la civilización, Eliot olvidaba que «la poesía no sólo registra estados espirituales del ser, o lo que se solía llamar el "espíritu» de una época; también registra los efectos espirituales de un clima y un hábitat cambiantes». Porque los poetas, desde un punto de vista ecológico, han sido clarividentes: "La mejor poesía moderna es una especie de ecología espiritual. La tierra baldía crece por dentro y por fuera y sin ninguna distinción esencial entre ellos, hasta tal punto que podríamos decir ahora que un poema como La tierra baldia de Eliot es, en algunos sentidos, un heraldo del efecto invernadero. O mejor, podemos decir que el efecto invernadero, o la desertización del hábitat en general, es el verdadero "correlato objetivo" del poema» (1993: 149). 
lar, como un oikos perdido, y el arte brota con el propósito, consciente o inconsciente, de ocuparse de la pérdida, llorándola, recordándola o reconstituyendo su espacio imaginario. El arte llega a ser «el lugar del exilio donde lamentamos nuestra morada perdida sobre la tierra» (Bate, 74).

En el artículo «La ilusión del origen», Jorge Riechmann denuncia las aporías implícitas, para él, en el hipotético regreso a los orígenes postulado por poetas afines al surrealismo que pretenden, como Octavio Paz, «la reconquista de un reino perdido: la palabra del principio, el hombre anterior a los hombres y a las civilizaciones». Riechmann rechaza como quimérica cualquier aspiración hacia la pureza o hacia un paraíso perdido: «no hay repristinación: somos seres de lo mestizo, de la mixitud. No podemos bañarnos en las fuentes del origen». Además, aunque pudiéramos bañarnos en ellas, sólo encontraríamos que «los orígenes son tan mestizos e "impuros" como nuestro "corrupto" presente. No querer reconocer esto es lo que suelo llamar la ilusión del origen». En contra de una poesía anclada en esta ilusión y en la nostalgia de lo perdido, Riechmann propone una poesía de la presencia y de la aceptación: hay que «afirmar sin desmayo la plenitud posible de la experiencia en el más acá» y abrir los ojos a nuestro entorno, siempre nuevo y sorprendente en su belleza. Abrir los ojos: enfocar la mirada; conjurar las riquezas de cada lugar (2001'a: 148-149).

Por otro lado, más allá de lo ilusorio de esta búsqueda de los orígenes, Riechmann palpa en ella las semillas de la intolerancia y afirma, con René Char, que «la Edad de Oro no es sino un crimen diferido». Allí, en el mismo concepto de pureza, está el problema: «si la nostalgia de lo originario se halla conectado de cualquier manera con el anhelo de pureza, deberían erizársenos todos los pelos del cuerpo». El sueño de lo puro y de los tiempos «dorados» engendra, ha engendrado monstruos —entre ellos, notoriamente, el monstruo nazi-. Por tanto, concluye Riechmann, más sabio sería reconocer la mixitud, aceptar las contradicciones y renunciar a esa búsqueda tan surrealista, tan romántica de una síntesis de los opuestos $(150-151)$.

Pese a estas descalificaciones, la tradición occidental hace pensar que el recurrente mito de la Edad de Oro encarna una especie de imperativo cultural. En su célebre estudio The Country and the City, Raymond Williams imagina a todas las generaciones históricas del hombre (se refiere al contexto inglés, pero lo sobrepasa) viajando cuesta abajo en una escalera automá- 
tica, pero mirando hacia atrás y añorando cada una los años de su infancia, o bien la vida mejor de sus padres y sobre todo la de sus abuelos y sus antepasados. La felicidad, la comunidad orgánica y el paraíso perdido existieron, de verdad existieron, pero siempre antes, ese muy poco antes: para el mundo sajón, antes de la tiranía normanda; para los celtas, antes de la invasión sajona; para el mundo íbero, antes de la barbarie celta; y así, y así, ad infinitum. Como comenta Williams, esta escalera automática podrá detenerse por fin en el Edén cristiano o en la Edad de Oro de los griegos (1985: 9-12).

Reconocer y desenmascarar esta nostalgia tan duradera como un mito - mito, en el peor sentido de la palabra, como lo no verdadero, como una falsificación - permite ver, desde luego, todas las injusticias y la explotación ocultadas sistemáticamente bajo la bucólica fachada de la poesía pastoril, tan apreciada por los terratenientes más estetas. Además, desmitificar está al orden del día en estos tiempos postmodernos. Nuestra mirada cada vez más racional —aunque cada vez, acaso, menos racionalista (menos confiada, al menos, en su razón) — desnuda al pensamiento mítico y utópico, cuyo paso de la teoría a la práctica desembocaría, se dice, inexorablemente en la aberración histórica y el terror. Muerte, entonces, a los mitos, a la poetización de los mitos y a la divulgación de los grandes relatos falsos. Pero aquí surgen tres preguntas. Por un lado, ¿se puede simplemente anular los mitos, extirparlos como un cáncer o despreciarlos como si fueran sólo los sueños irresponsables de la adolescencia humana? Además, si los mitos se niegan, recalcitrantes, a desaparecer, ¿realmente es deseable (intentar) rematarlos? Y por último, ¿no es cierto que, esta vez sí, para nosotros el pasado ha sido verdaderamente mejor — desde la perspectiva de la salud ecológica del planeta- que el presente?

Para Char y Riechmann, el discurso de las raíces, de los orígenes prístinos y de la Edad de Oro puede mutilar al ser humano, perderlo en la nostalgia, volverlo incapaz de vivir y percibir la belleza tangible de su entorno. De ahí la apuesta por una poesía del presente y de la aceptación. Sin embargo, ¿no empobrece un panpanvinismo tan radical? Y al desterrar a los mitos, ¿no se terminará desterrando a la magia de esas historias que siempre han sustentado a los niños, y a la avidez maravillada y acaso intemporal que suscita ese "érase una vez»? Mitificar la infancia puede ser falsificarla, como dice el más lúcido de los desmitificadores, Nicanor Parra: «yo nací y me crié en una casa rodeada de mierda». No obstante, también 
puede abrirse a verdades no tan evidentes, pero necesarias. En la obra, por ejemplo, del también chileno Jorge Teillier, persisten la mitificación de la infancia y el esfuerzo por reconstruir una Edad de Oro. Y para él, precisamente, es el recuerdo de las maravillas vividas, contadas y leídas en los primeros años el que permite al poeta seguir buscando y experimentando la belleza en su madurez. El mito de tiempos mejores perdidos no tiene por qué inmovilizar al ser humano; al contrario, resulta imprescindible para que sepa vivir el presente en su plenitud (porque sabe de esa plenitud en el pasado) y para que no deje de luchar, en el más acá, por una vida mejor (porque sabe que ésta puede volver a existir). Poner frenos a la imaginación y limitarse al panpanvinismo del presente es mutilar la existencia.

Además, la Edad de Oro no tiene por qué apelar a la pureza. ${ }^{7}$ Ovidio, en su Metamorfosis, concibió el origen no en términos de pureza racial, sino como una imagen de convivencia armónica, una mezcla pacífica de razas y culturas y especies. En cierto sentido, como dice Riechmann, los orígenes son "tan mestizos e "impuros" como nuestro "corrupto" presente». Pero ojo: hay mestizajes que enriquecen y mestizajes que corrompen; mestizajes fraternales y mestizajes desequilibrantes, avasalladores y ecológicamente suicidas (piénsese, por ejemplo, en los que promueven los massmedia y la economía global). Por eso me interesa el caso de Teillier, porque los «orígenes» que él rescata en su poesía se caracterizan explícitamente por la mixitud, y quizá hasta se podría decir que por la pureza de la mixitud. Es cierto que el pueblo de Teillier (en su poesía, pero también en la "realidad histórica» de su pueblo natal de Lautaro) es producto de la brutal y tardía conquista del sur de Chile. Sin embargo, de la barbarie de «los que mataron mapuches y aprendieron de los mapuches a beber sangre de corderos recién sacrificados» (1968: 15) surgió una comunidad en que las culturas mapuche, española, francesa, alemana y suiza coexisten —al menos en la poesía de Teillier- en paz. Desde el caos bélico emerge una Edad de Oro mestiza que no remonta a tiempos inmemoriales sino que se

7 Michel Tournier opone al concepto de la pureza el de la inocencia. Mientras «el hombre poseído por el demonio de la pureza siembra la muerte y la ruina a su alrededor», la inocencia es la «inversión bienhechora» de la pureza, característica del animal, el niño y el débil mental. En una línea compatible con la búsqueda de una Edad de Oro, el francés afirma que «el hombre adulto y razonable puede fijarse como ideal un estado que sería el de su infancia, prolongada y preservada» (2000: 154). 
fecha a finales del siglo XIX y se reviste de toda la dignidad del mito. Es un mito que no pretende refugiarse nostálgicamente en el pasado. Al contrario, como dijo Teillier en una entrevista de 1966: «Yo confío en un mundo mejor. Mi poesía está apuntando hacia el paraíso perdido, hacia el retorno de la edad de oro, que no es sólo un mito enajenante, sino una realidad que el hombre puede alcanzar, pienso, dentro de sí primero (la toma de conciencia) y luego proyectada hacia los demás, hacia toda la sociedad» (2000: 8-9). ${ }^{8}$ La Edad de Oro ofrece un modelo de mestizaje pacífico al que se podrá acceder tanto en el presente como en el futuro.

En uno de los más lúcidos y hermosos libros de "ecocrítica», The Song of the Earth, Jonathan Bate ha enfocado la insistencia de esa mirada hacia tiempos mejores, representada por Williams en la imagen de la escalera automática, y ve en la recuperación actual del mito de la Edad de Oro, más allá de las aberraciones y las falsificaciones que puede encarnar, una especie de admonición o freno ecológico para el homo sapiens depredador (2000: 25-26). ${ }^{9}$ En este sentido, la Edad de Oro de Teillier y otros poetas contemporáneos no sería un crimen diferido sino un crimen impedido o que se pretende, por lo menos, impedir.

\section{En busca de la Armonía}

Contra el caos, la búsqueda de la armonía. Recuperar la idea de un pasado mejor, tanto en la vida como en la poesía, es reclamar la armonía en desafío a la destrucción imperante. Como constructor de un nuevo oikos en la tie-

8 Otro poeta contemporáneo que rearticula este discurso es Ernesto Cardenal. En «Hacia el hombre nuevo», la Cantiga 19 de su Cántico cósmico, también funde su visión utópica del futuro (post-revolucionario) con la perdida Edad de Oro: «Los hombres de la Edad de Oro, o Edad de Piedra / (paleolítico superior), / "los mejores artífices de la piedra de todos los tiempos" / [...] / No había reyes ni dictadores, primer ministro, policías, cárceles, burócratas. / Nadie se arrodillaba humildemente para saludar a nadie. / La edad de oro: científicamente cierto / según Hellmich. / Debió existir realmente la edad de oro: / "Por leyes de la psicología y de la lógica..."” (1993: 155-156).

9 A veces, el regreso a la Edad de Oro puede caer en una especie de bucolismo barato, pero Terry Gifford ha señalado la complejidad de la poesía "post-pastoril» de autores como Ted Hughes y Seamus Heaney, para quienes el mundo estático de la tradición virgiliana ha sido reemplazado por una naturaleza dinámica, sujeta a los procesos cíclicos, en la que el hombre se reconoce como un ser alienado de su naturaleza animal (1995: 121). 
rra, como rescatador de edades de oro y acicate para una sociedad adormeci$\mathrm{da}$, el poeta se convierte en portavoz de la esperanza en medio de nuestra crisis ecológica: «¿Podría ser el poeta una subespecie clave de Homo sapiens? El poeta: una criatura aparentemente inútil, pero potencialmente el salvador de los ecosistemas» (Bate, 230). ${ }^{10}$ Asimismo, Octavio Paz encuentra en la aspiración analógica — clave a lo largo de la modernidad, dice él, en lucha encarnizada con su opuesto: la ironía - la posibilidad de «la supervivencia del género humano en una tierra envenenada y asolada» (1999: 704):

Espejo de la fraternidad cósmica, el poema es un modelo de lo que podría ser la sociedad humana. Frente a la destrucción de la naturaleza, muestra la hermandad entre los astros y las partículas, las substancias químicas y la conciencia. La poesía ejercita nuestra imaginación y así nos enseña a reconocer las diferencias y a descubrir las semejanzas. El universo es un tejido vivo de afinidades y oposiciones. Prueba viviente de la fraternidad universal, cada poema es una lección práctica de armonía y de concordia, aunque su tema sea la cólera del héroe, la soledad de la muchacha abandonada o el hundirse de la conciencia en el agua quieta del espejo. La poesía es el antídoto de la técnica y del mercado. A eso se reduce lo que podría ser, en nuestro tiempo y en el que llega, la función de la poesía. ¿¿Nada más? Nada menos. (705)

Esta visión de la hermandad de los elementos y los seres humanos, y la noción del universo como "un tejido vivo de afinidades y oposiciones», se acercan al mundo de interconexiones e interdependencias de la ecología que Leonardo Boff ha iluminado con una gráfica definición:

La singularidad del saber ecológico reside en su transversalidad, es decir, en el relacionar hacia los lados (comunidad ecológica), hacia adelante (futuro), hacia atrás (pasado) y hacia dentro (complejidad) todas las experiencias y todas las formas de comprensión como complementarias y útiles para nuestro conocimiento del universo, nuestra funcionalidad dentro de él, y para la solidaridad cósmica que nos une a todos. (1996a: 16)

Esta visión holística — holismo: la idea de que la totalidad no es una suma de las partes, sino la red de relaciones que hay entre ellas- es esencial en la ecología, y ha llevado a Boff a adoptar la imagen de Gaia popu-

10 También: «Podríamos preguntar: dado lo frágiles, elusivos y poco prácticos que son los poemas, ¿no resulta sorprendente el simple hecho de que sobrevivan? ¿¿No es posible que la supervivencia de ciertos poemas se deba al hecho de que, como las especies seleccionadas naturalmente dentro de la evolución de los ecosistemas, cumplan con éxito una necesidad en nuestra ecología distintivamente humana?» (Bate, 246). 
larizada por el científico inglés James Lovelock —que retrata a la Tierra como un organismo vivo complejísimo- en contraste con las ideas arquetípicamente modernas del planeta como un objeto inerte.

El hecho de que Lovelock sea un científico no es casual. Llega el momento en que tanto la ciencia como el arte (en su búsqueda de la armonía que señala Paz) se enfrentan al laberíntico entramado de relaciones que sostiene al mundo. Para Leonard Scigaj, que ejerce como una especie de policía ecológico en su libro Sustainable Poetry (va diciendo: este escritor es ecológico; este otro no lo es), la poesía ecológica es la que «ha sido influenciada conscientemente por una sensibilidad hacia el pensamiento ecológico, sobre todo en las áreas de flujo y retención de energía, renovación cíclica, biorregionalismo y la interdependencia de todos los organismos dentro de un ecosistema» (Scigaj, 11). ${ }^{11}$ La poesía ecológica, provista de estos conocimientos y de la sensibilidad adecuada, sería una poesía sustentable, "que no permite la degradación de los ecosistemas» (5). Las ideas de Scigaj conducen, sin duda, al panfleto ecologista, y haríamos bien en recordar, con Paz, que la poesía, aun en sus intentos de promover la supervivencia del planeta, tiene una función siempre indirecta (1999: 704), y en exigir conocimientos científicos más a los ecocríticos que a los poetas. Al fin y al cabo, todos los poetas pueden ser leídos desde posturas ecocríticas, del mismo modo en que la crítica feminista y marxista no tiene por qué limitarse a textos militantes de un mismo pensar. Le corresponde al ecocrítico, y no al poeta, armarse de conocimientos y darse cuenta de la complejidad ecológica del mundo. Como dice Kroeber: «a no ser que reconozcamos la complejidad de la ecología científica, caemos en un sentimentalismo barato que puede, de hecho, resultar destructivo para nuestro entorno natural» (1994: 27).

\section{La respuesta indígena, los ecoteólogos y el ecofeminismo}

Si las representaciones contemporáneas de la edad de oro o de la armonía corresponden, como desean Bate y Paz, a una necesidad profunda-

11 El caso más notorio en el mundo hispanoamericano sería Ernesto Cardenal, cuyo Cántico cósmico (1993), citado arriba, cumple con los rígidos requisitos de Scigaj y tiene bastante que ver con la obra de A.R. Ammons, uno de los poetas estudiados por el crítico norteamericano. 
mente humana, en Hispanoamérica se articulan a menudo en torno a relatos o imágenes tomados del mundo indígena, a través de lecturas ecoteológicas de la tradición cristiana, o bien de acuerdo con las premisas del movimiento ecofeminista que ha surgido en los últimos años.

Tanto para Boff como para Cardenal, el mundo indígena sirve como una especie de muestra de una edad de oro ecológica y como un modelo para la anhelada sociedad futura. Ya en 1970, Cardenal publicó su Homenaje a los indios americanos, con poemas tan abiertamente ecologistas como «La danza del espíritu». Boff, por su parte, afirma que los pueblos primitivos que siguen viviendo «la dimensión de lo sagrado y la de la religación con todas las cosas» son "portadores de un significado importante para la crisis ecológica» (1996a: 158). El concepto clave aquí es la religación: al perder la noción de la vida como una red, hemos quebrado los vínculos básicos. Se trataría, por tanto, de religarlos, usando como posible paradigma las sociedades indígenas, ejemplares en su sabiduría ancestral, en su utilización y su mística de la naturaleza, y en sus visiones, tan ajenas a las occidentales, del trabajo, la fiesta y la danza (159-163). Este ecologismo avant la lettre (mencionado más arriba por Fernando Mires) explica en parte el renovado interés por textos como el Popol Vuh y el «descubrimiento" reciente, en muchos países latinoamericanos, de la poesía indígena. El interés de ésta, desde posturas ecocríticas, me parece doble: por un lado, la armonía con el entorno que a menudo representa rompe radicalmente con las visiones dominantes de la naturaleza; por otro, la recepción entusiasta de esta poesía, más allá del reconocimiento del valor de una obra tradicionalmente marginada, corresponde a cierto malestar social y ecológico de los centros culturales. En Chile, el prólogo que hizo Raúl Zurita en 1989 para el poeta mapuche Leonel Lienlaf es emblemático. Cuenta su experiencia con el joven Lienlaf y con otros mapuches durante una estancia como «escritor residente» en Temuco:

Los peñis, mis hermanos mapuches, poco a poco me fueron devolviendo a una voz más profunda que habitaba en mí y tuve la certeza de que ésta era una escena que volvía a vivir. Que en realidad a todos nos es dado —al menos una vez en la vida - una cierta experiencia de la totalidad, de esa «respiración del universo", pero que también —obligados por un mundo con otros vértigos - a menudo cometemos su olvido. [...] Cada vez que no escuchamos el lenguaje de la tierra que nos cobija y que nos hace a todos por igual «hijos de ella», es algo de nosotros lo que violamos. (Lienlaf, 14-15) 
En efecto, la «oralitura» mapuche de Lienlaf o de Elicura Chihuailaf presenta sin estridencias una visión de la armonía, de ese orden que siempre han buscado los poetas modernos de Occidente. La aspiración analógica y mítica de los modernos y la búsqueda del arraigo son dones naturales para el hablante indígena:

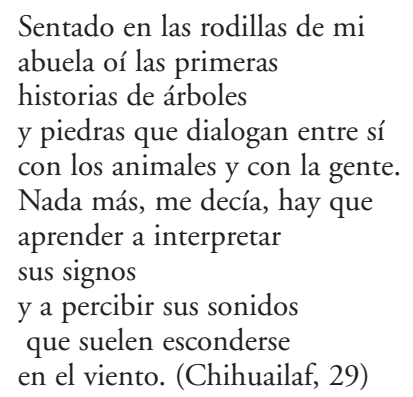

Tanto Boff como Cardenal son católicos, teólogos de la liberación convertidos en ecologistas. Ya en 1967, Lynn White, Jr. había denunciado el cristianismo como «la religión más antropocéntrica jamás vista por el mundo» (1996: 9), proponiendo a la vez a San Francisco de Asís como santo patrono de los ecologistas. Boff cita a White y señala «seis puntos de connotación antiecológica en la tradición judeocristiana»: el patriarcalismo (que margina la actitud más ecocéntrica de la mujer); el monoteísmo (que niega el misterio y la sacralidad de todos los seres vivos); el antropocentrismo (fruto de una lectura literal del Génesis: «sed fecundos, multiplicaos, llenad la Tierra y sometedla; dominad sobre los peces del mar, las aves del cielo»); la ideología tribal (la arrogancia bélica de los «elegidos por Dios», portadores de la «verdad» en contra de la solidaridad ecológica universal); la creencia en la naturaleza caída (la visión de la materia como algo corrupto y por lo tanto desdeñable); y por último, el pecado original de la ruptura permanente de la religación universal, la alienación radical respecto al resto del universo (1996: 102-106). La fusión entre los discursos de la teología de la liberación y de la ecología resulta natural, según Boff, porque ambos parten de "heridas sangrantes» - la herida de la pobreza y la miseria, por un lado; por otro, la de la agresión sistemática a la tierra-y porque se elevan en dos gritos: el grito de los pobres por la vida, la libertad y la belleza; y el grito de la Tierra explotada (135). Esta fusión permite, como en White, la celebración de 
San Francisco como el gran paradigma para la ecoteología, el que encarna «todas las virtudes cardinales ecológicas» (253). ${ }^{12}$

Otra búsqueda de un mundo ecológicamente más feliz hunde sus raíces en épocas anteriores al sistema patriarcal imperante, identificando matriarcados armónicos en un pasado mítico donde todavía se veneraba a la gran Tierra Madre. El llamado ecofeminismo ha unido la militancia feminista con la ecologista y estudia cómo el antropocentrismo moderno ha sido, en realidad, un androcentrismo, una idea y un poder que han servido para explotar paralela y simultáneamente a las mujeres y la naturaleza. Aparte de rastrear la literatura por visiones e imágenes surgidas de esta injusticia secular, el ecofeminismo investiga cómo las metáforas e imágenes literarias han reflejado o rechazado la analogía mujer-naturaleza, y cómo el interés actual por la Diosa retoma y reelabora una larguísima tradición mítica y literaria que proviene, en la tradición grecolatina, de la Gaia de los himnos homéricos (y hoy, del científico Lovelock). Como veremos después, estas ideas resultan particularmente apropiadas para leer la obra de Gabriela Mistral.

\section{Apocalypse Now y la conciencia tóxica}

El mito del apocalipsis encontró en las bombas atómicas de Hiroshima y Nagasaki y en la progresiva destrucción ecológica del planeta un campo riquísimo. En lengua inglesa, John Bradley ha publicado Atomic Ghost (1995), una extensa antología de poetas de la era nuclear; en lengua española se podría hacer una antología igualmente impresionante. Destacan poetas como Ernesto Cardenal - tanto en Salmos como en su conocido «Apocalipsis»—, Pablo Neruda, Idea Vilariño y Óscar Hahn. El caso de Hahn es estremecedor. ¿Hasta qué punto estamos condicionados ono-

12 Ingemar Hedstrom y José Francisco Gómez también citan a San Francisco como precursor de la "fraternidad con la naturaleza» buscada por la ecofilia (1991: 139), pero encuentran otro modelo utópico para la ecología (una edad de oro arquetípica) en Isaías 11, vv. 6-9: «El lobo habitará con el cordero, el puma se acostará junto al cabrito, el ternero comerá al lado del león y un niño chiquitito los cuidará. La vaca y el oso pastarán en compañía y sus crías reposarán juntas, pues el león también comerá pasto, igual que el buey. El niño de pecho pisará el hoyo de la víbora, y sobre la cueva de la culebra el pequeñuelo colocará su mano" (142). 
másticamente, condenados a arrastrarnos detrás de obsesiones impuestas de antemano por nuestros nombres. Hahn comparte apellido e inicial con Otto Hahn, descubridor de la fisión nuclear y premio Nobel de Química en 1944 (fíjense en el año), y comparte también, como una fatalidad, su tema, como se puede ver en sus seis Imágenes nucleares (1983), cargadas de resonancias del Apocalipsis de San Juan, y en diversos poemas posteriores.

Cuando Rachel Carson publicó Silent Spring en 1962, el apocalipsis se había hecho presente en el mundo de manera más sigilosa, sembrándose por los ecosistemas norteamericanos a través de mortíferos pesticidas y herbicidas, en primerísimo lugar el tristemente célebre DDT. El libro de Carson, que es en esencia un texto de investigación científica lleno de tecnicismos y estadísticas, se convirtió en best-seller gracias al estremecimiento pasional de su relato y a la enorme fuerza de sus imágenes. Empieza con «Una fábula para mañana», una parábola sobre un pueblo estadounidense arquetípico — «Érase una vez un pueblo en el corazón de América donde toda la vida parecía vivir en armonía con su entorno» (2000: 21) — que ha perdido todo rastro de vida: ya no cantan pájaros (de ahí, la primavera silenciosa); no hay vegetación, ni ganado, ni peces. Estamos en el mundo del apocalipsis, pero «ninguna brujería, ninguna acción enemiga había silenciado el renacer de la vida nueva en el mundo afligido. Fue la gente misma quien lo había hecho» (22). Asimismo, Carson se apropia de analogías históricas — en el mundo contaminado que relata, «estamos en una posición poco mejor que la de los invitados de los Borgia» (167)_, imágenes de Keats (el verso And no birds sing, del poema "La belle dame sans merci», sirve como título), Lewis Carroll, Robert Frost y los hermanos Grimm:

El mundo de los insecticidas sistémicos es un mundo peculiar, que sobrepasa lo imaginado por los hermanos Grimm — quizá más cercano al mundo de los dibujos animados de Charles Addams-. Es un mundo donde el bosque encantado de los cuentos de hadas se ha transformado en el bosque envenenado donde un insecto que mastica una hoja o sorbe la savia de una planta está condenado. Es un mundo donde una pulga pica a un perro y muere porque la sangre del perro ha sido convertida en veneno, donde un insecto puede morir de los vapores que emanan de una planta que jamás tocó, donde una abeja puede llevar néctar envenenado de vuelta a su colmena y pronto producir una miel envenenada. (46)

En este nuevo mundo del apocalipsis, poetas como José Emilio Pacheco y Homero Aridjis han encontrado una veta riquísima de imá- 
genes para hablar de la destrucción ecológica que está minando o invalidando varios de los símbolos poéticos supuestamente más «intemporales»: el bosque encantado, ahora envenenado; la madre tierra, hoy tierra baldía; el aire transparente, visible en su contaminación; el cielo infinito, desgarrado por el agujero en la capa de ozono; la lluvia purificadora, hoy lluvia ácida; mares agonizantes; ríos y lagos biológicamente muertos. Decir hoy estas palabras suscita connotaciones en pugna: por un lado, el simbolismo poético, idealizador; por otro, la realidad contaminada y contaminante. Lo queramos o no, para un lector actual, nuestras vidas son ríos contaminados que van a dar en una mar contaminada. Carson empezó su libro con una fábula apocalíptica para mañana, pero es, en realidad, una realidad para hoy. ${ }^{13}$

En relación con esta reapropiación del mito del apocalipsis, algunos ecocríticos se han referido a la "conciencia tóxica» (toxic consciousness), la presencia de la contaminación y los restos tóxicos en mucha literatura reciente, producto del «cambio desde una cultura definida por su producción hacia una cultura definida por sus desechos» (Deitering, 196). En su reciente libro, Writing for an Endangered World, Lawrence Buell ha examinado cómo esta conciencia tóxica busca salida en una serie de tópicos: mediante el escándalo de la percepción despertada, en expresiones de desencanto como el libro de Carson, en imágenes del Edén envenenado, en las tecnodistopías, etc. (2001: 35-38); mediante imágenes totalizadoras de un mundo sin refugio posible, unificado globalmente por la contaminación (38-40); mediante la pasión moral de un David en el escenario de los Goliat, en resistencia heroica contra las grandes empresas depredadoras y en las luchas locales de anti-globalización (40-42); y por último, mediante la gotificación y el recurso al horror (42-43).

Este discurso tóxico me parece de interés no sólo por las posibilidades enunciadas, sino también porque permite concebir una toxicidad más profunda en la literatura contemporánea, que no se limitaría al desarrai-

13 Lo dice Riechmann: «Lo que de verdad debería ocuparnos no son las fantasías del Armagedón final sino la omnipresencia del apocalipsis cotidiano. El daño a la biosfera y el socavamiento de la autonomía del ser humano se están produciendo ahora; el trabajo de los poderes económico-políticos contra las alternativas que nos salvarían está teniendo lugar ahora» (2001: 12). 
go de la literatura smog denunciada por Marta Sosa. Así, por ejemplo, sería interesante examinar cómo los escritores que hoy enfrentan la gran temática contemporánea de la basura, aprovechan los recursos de fragmentación y montaje de las vanguardias, o bien, hasta qué punto se han dejado impregnar por la contaminación lingüística que nos rodea. Si palabras como cielo, aire, agua, río, lago y lluvia no sirven como antes para connotar pureza, ¿cómo puede responder el poeta sino mediante un profundo cuestionamiento del lenguaje? Paz veía la poesía como una apuesta por la armonía como antídoto a la técnica y al desastre ecológico. Joaquín Araújo, por su parte, relaciona su perspectiva de ecologista con la tradición poética de lo sagrado y con la veneración de la naturaleza de Robert Graves, y resucita una memorable reflexión de La Diosa Blanca, donde Graves manifestó su plena conciencia de que la naturaleza y las palabras que la refieren estaban en crisis:

¿Cuál es la utilidad o función de la poesía en la actualidad? Es una pregunta no menos acerba porque la hagan con insolencia tantos estúpidos o que la respondan con apologías tantos tontos. La función de la poesía es la invocación religiosa de la Musa; su utilidad es la mezcla de exaltación y de horror que su presencia suscita. ¿Pero «en la actualidad»? La función y la utilidad siguen siendo las mismas; sólo la aplicación ha cambiado. Ésta era en un tiempo una advertencia al hombre de que debía mantenerse en armonía con la familia de criaturas vivientes entre las cuales había nacido, mediante la obediencia a los deseos del ama de casa; ahora es un recordatorio de que no ha tenido en cuenta la advertencia, ha trastornado la casa con sus caprichosos experimentos en la filosofía, la ciencia y la industria, y se ha arruinado a sí mismo y a su familia: La «actual» es una civilización en la que son deshonrados los principales emblemas de la poesía. En la que la serpiente, el león y el águila corresponden a la carpa del circo; el buey, el salmón y el jabalí a la fábrica de conservas; el caballo de carreras y el lebrel a las pistas de apuestas; y el bosquecillo sagrado al aserradero. En la que la Luna es menospreciada como un apagado satélite de la Tierra y la mujer considerada como "personal auxiliar del Estado». En la que el dinero puede comprar casi todo menos la verdad y a casi todos menos al poeta poseído por la verdad. (Araújo, 223)

\section{La ecocrítica en Hispanoamérica}

Los dos textos claves para la ecocrítica en Hispanoamérica son las monografías de Hispanic Journal (1998) e Ixquic (2000), y en particular los artículos panorámicos — casi manifiestos, o declaraciones de princi- 
pios- de Roberto Forns-Broggi y de Jorge Paredes y Benjamin McLean. Ofreceré un breve resumen de ambos, porque son, dentro del panorama actual de la crítica de lengua española, puntos de partida esenciales. ${ }^{14}$

En «¿Cuáles son los dones que la naturaleza regala a la poesía latinoamericana?», ${ }^{15}$ Forns-Broggi estudia con detenimiento cuatro de estos dones: el don del reparo se refiere al uso literario de la ecología «como arma crítica y analítica frente al proceso de modernización». Así, por ejemplo, Ernesto Cardenal enfoca la desaparición de los ecosistemas y las culturas indígenas, y Octavio Paz y Homero Aridjis poetizan la contaminación de la ciudad de México (1998: 212-214); el don de la celebración se encuentra en poetas que abrazan "proyectos abiertos de integración cósmica», como es el caso de Neruda o de Jorge Carrera Andrade, de la poesía quechua de José María Arguedas, o del poeta mexicano Alberto Blanco (214-218); el don de la hospitalidad remite a la consagración de ese oikos que está en la raíz de la palabra ecología, y aparece sobre todo en Roberto Juarroz, pero también en poetas centroamericanos como Pablo Antonio Cuadra y Laureano Albán, y en el peruano William Hurtado de Mendoza (219-222); por último, el don de la voz femenina se percibe en la obra de Gioconda Belli, que rehúye las imposiciones patriarcales y retrata lo femenino como «una fuerza dinámica e interdependiente con la naturaleza», así como en muchas otras poetas hispanoamericanas actuales (222-228).

En «Hacia una tipología de la literatura ecológica en español», Paredes y McLean contrastan el desinterés por la naturaleza de los escritores españoles con una actitud mucho más preocupada por parte de los hispanoamericanos. Esta diferencia estaría directamente relacionada a la vigencia de las culturas prehispánicas: «el "Nuevo Mundo" cuenta con la ventaja también de tener en el Popol Vuh una de las dos raíces de su tradición narrativa, lo que le proporciona una sensibilidad ecológica por la herencia cultural, que contrarresta el humanismo judeo-cristiano que le legara el colonialismo

14 Me ha llegado en estos días el primer monográfico de ecocrítica en el mundo hispanoparlante, un apasionado y apasionante estudio de Stephen White, El mundo más que humano en la poesía de Pablo Antonio Cuadra. Un estudio ecocrítico.

15 Para otros estudios sobre poesía ecológica, véanse los artículos de Carmen M. Rivera Villegas, Peter Elmore y Stephen M. Hart. 
español» (2000: 21). Para investigar cómo esta sensibilidad ecológica hispanoamericana se manifiesta hoy, formulan la siguiente definición:

La literatura ecologista es un ejercicio de escritura artística que, en su esencia discursiva, muestra una actitud de admiración y respeto por todos los elementos que conforman la realidad natural del mundo y todas sus formas de vida, y un grado definitivo de conciencia sobre la dependencia de la especie humana en otras formas de vida para su continuada existencia. Entre las características principales de esta tendencia literaria, tenemos: 1) la denuncia constante del sistema social impuesto por el humanismo europeo (el patriarcalismo), los sistemas políticos y la corrupción de los gobernantes; 2) la apertura de espacios narrativos y discursivos de las culturas aborígenes, con lo que se les devuelve la voz que les arrebatara el colonialismo europeo hace cinco siglos; 3) el redescubrimiento y utilización de mitos ancestrales y populares, como respuesta a la mitificación del hombre occidental del desarrollo desaforado y el dinero; 4) el intercalar en las construcciones artísticas, hechos y datos verificables, para dar más fuerza y veracidad a sus propuestas; 5) una constante revisita [sic] y cuestionamiento a las versiones oficiales de la historia, para desmitificarlas y reescribirlas a partir de la visión del mundo del «otro»; 6) un constante dialogismo, que muchas veces resulta en fusión, con otras expresiones discursivas posmodernas, entre las que se favorece la feminista, la poscolonialista, la neoindigenista y la cultura popular. (34-35)

Dentro del corpus básico de textos ecologistas, los autores excluyen la novela de la tierra - porque «el hombre aparece siempre en un enfrentamiento a muerte con los elementos de la Naturaleza» (21)_, pero destacan la obra testimonial de Rigoberta Menchú, las novelas de Gioconda Belli, Anacristina Rossi y Luis Sepúlveda, la poesía de Octavio Paz y de Ernesto Cardenal, y los ensayos de Eduardo Galeano (23). La preponderancia de escritores mesoamericanos en este corpus sería una consecuencia del auténtico desastre ecológico que ahí se padece y por ser Mesoamérica la cuna de la cultura maya, "cuya visión de mundo y cosmología predican más abierta y directamente la necesidad de crear un balance entre todos los seres vivos y demás fenómenos naturales» (24-25). 


\section{CAPÍTULO 2. \\ CRIATURAS DEL DESARRAIGO, O EN BUSCA DE LOS LUGARES PERDIDOS: ALIENACIÓN Y ECOLOGÍA EN LA POESÍA HISPANOAMERICANA}

The true poet has to be simultaneously a geographer of the imagination and a historian of the alienations and desecrations that follow the march of «civilization».

Jonathan Bate

Somos criaturas del desarraigo moderno y lo estamos empezando a lamentar. El término en sí, desarraigo, irradia hoy connotaciones desoladoras, y no obstante, sin desarraigo la modernidad no habría sido, como fue, gloriosa para la especie humana. Al romper con sus raíces, reclamando su autonomía como seres libres, los modernos pudieron apropiarse de la historia, hacerse aparentemente sujetos de ella, desafiar y trascender los determinismos del lugar y de la tradición, y forjar un nuevo mundo construido por ellos a su antojo y supuestamente a su medida. Los animales se pliegan a las exigencias del entorno local; los seres humanos modernos, en cambio, no: son racionales, urbanos y cosmopolitas, dueños de sí mismos, hermanados universalmente en su recién descubierta humanidad.

El desarraigo echó sus propias tenues raíces en Occidente con la brusca confluencia, a finales del siglo XVIII, de las modernidades ideológica (la Ilustración), política (Revolución francesa) y tecnológica (revolución industrial), 
y con la consiguiente explosión de grandes urbes centralizadoras y del nuevo ser humano que las poblaba. Esta consagración del desarraigo provocó la primera y consabida reacción de los románticos: ahí están, como testimonio, el Londres cartografiado hasta la inhumanidad de Blake y el solitario - y tan poco convincente- esfuerzo de Wordsworth por ver la gran capital con sus ojos bucólicos, más acostumbrados al lago Windermere. ${ }^{16}$ Para los románticos y los tradicionalistas, desarraigo significaba, fatalmente, alienación y deshumanización. Pero estos conceptos, como señala Luc Ferry, varían enormemente según la perspectiva: «Al romántico que considera que el hombre abstracto ya no es un hombre, el Aufklärer responde que es el individuo arraigado, totalmente determinado por su situación, el que por el contrario retorna a la naturaleza y pierde así su cualidad de humano» (1994: 48). ¿Qué ha sido la modernidad: la plenitud del ser humano libre o la alienación del hombre despojado de sus raíces? Ferry propone una posible síntesis a las contrapuestas fuerzas de lo particular y lo universal:

Está claro que toda cultura digna de este nombre, toda obra de envergadura, es a la vez particular, arraigada en un espacio y en un tiempo determinados, y universal, dotada de significaciones accesibles a otros hombres que aquellos que componen la comunidad de origen. A través de ello se vuelve singular, forma una «individualidad», en el supuesto de que efectivamente lo singular sea la reconciliación de lo particular y de lo universal. (49)

Desde una perspectiva ecologista, la cuestión del desarraigo está relacionada ineludiblemente con la degradación del entorno humano que ha

16 El poema «London» de Blake empieza: «I wander through each chartered street, / Near where the chartered Thames does flow, / And mark in very face I meet / Marks of weakness, marks of woe. // In every cry of every man, / In every infant's cry of fear, / In every voice, in every ban, / The mind-forged manacles I hear». Wordsworth, por su parte, en la epifanía urbana del soneto "Composed upon Westminster Bridge», afirma que la Tierra no tiene nada tan bello como Londres al alba; la calma y el esplendor de la ciudad todavía durmiente superan a los de la naturaleza, de los valles, de las rocas y los cerros tan celebrados por el poeta inglés: «Never did sun more beautifully steep / In his first splendor valley, rock, or hill / Ne'er saw I, never felt, a calm so deep». Jonathan Bate señala la extrañeza de esta visión: «en Wordsworth la ciudad suele ser un sitio de alienación, pero aquí, por su "calma" y "quietud" se transfigura» (Bate, 220). Desde luego, en el poema todo el bullicio y frenesí está aguardando el momento de despertar y desplegar sus poderes alienantes. Resulta interesante, en el contexto de estos poemas, la sugerencia de Bate de que los primeros usos de la palabra environment (medio ambiente) hayan sido una consecuencia directa de la experiencia de alienación en la gran ciudad moderna: antes no hacía falta semejante término, porque la influencia de las condiciones físicas en los seres humanos y sus comunidades resultaba demasiado evidente (13). 
sido otro de los frutos (de los frutos perniciosos) de la modernidad. La urbanización del mundo crea aglomeraciones humanas ecológicamente aberrantes, en sí mismas insostenibles, necesitadas de una importación masiva de recursos y de una exportación igualmente masiva de desechos: las comunidades que antes conformaban el campo, obligadas a satisfacer las exigencias de las grandes ciudades y asimilar sus desechos, viven en función de ellas y las acompañan en su degradación.

Se ha hablado tanto en las últimas décadas de una crisis ecológica —una crisis que no termina de afectar más que tangencialmente a la gran mayoría de los ciudadanos de Occidente-, que el discurso apocalíptico se ha desgastado y hasta adormece. ${ }^{17}$ Como si el ecologismo hubiera sido una moda pasajera. Supongamos que no, que la crisis sigue más crítica que nunca. Aceptemos, a la vez, que la "vuelta atrás» propuesta por la llamada ecología profunda (deep ecology) resulta inconcebible en las condiciones socioeconómicas actuales (el «triunfo» del capitalismo, la globalización, etc.). Lo que quiero explorar aquí es la posibilidad, primero, de que una de las claves para defendernos del colapso ecológico consista en la recuperación de un sentido de "arraigo», una reapropiación de ese oikos extraviado, pero sin renunciar del todo a las libertades modernas, y en segundo lugar, de que la poesía constituya una vía iluminadora para elucidar las búsquedas de esta recuperación. Tal vez se trate de encontrar esa reconciliación entre lo particular y lo universal que constituye la «singularidad».

Ferry contrapone dos estéticas que corresponderían al arraigo y al desarraigo: por un lado, la visión romántica de la obra como expresión del genio de cada pueblo (con el riesgo de caer en el nacionalismo y el folclore); por otro, el afán vanguardista de subvertir y trascender las formas estéticas locales y tradicionales (con el riesgo de caer en la banalidad de lo nuevo por lo nuevo) (218). Sin olvidar que poetas como Vallejo invalidan esta dicotomía, quisiera examinar en las siguientes páginas cómo la llegada a Hispanoamérica del decadentismo y de cierto vanguardismo (por ejemplo, Huidobro) significó la implantación de un discurso del desarraigo que aniquilaba

17 «"En la actualidad” —escribía Barry Commoner en 1971 al comienzo de su libro fundamental, El círculo que se cierra - "estos cuentos de miedo sobre la destrucción del medio ambiente son bien conocidos, incluso aburridos". ¿Estas cosas aburrían ya hace treinta años! Hoy seguimos igual, aterrados y hastiados al mismo tiempo, con la horrorosa sensación de no haber avanzado un paso» (Riechmann, 2001: 7). 
la especificidad de los lugares, los lenguajes y las tradiciones, en su búsqueda de un espacio ajeno a toda particularidad local (exagero, quizá, pero el abandono de lo particular es extremo), como ese paisaje anónimo que transitaban y transitan los flâneurs urbanos, zarandeados de estímulos, de escaparate en escaparate por las calles de hoy, decoradas todas con los mismos coches, la misma publicidad, con tiendas que anuncian las mismas marcas y resuenan con una música igual a lo largo y ancho del mundo contemporáneo. Detestar el tiempo y la vida en que nos tocó nacer ayuda poco (además, en muchos sentidos nosotros, los privilegiados, nunca nos hemos divertido tanto). Pero puede ser de interés indagar cómo recuperar un sentido de arraigo en el mundo contemporáneo, sin tener que volver atrás históricamente a pequeñas comunidades que hoy apenas —a durísimas penassobreviven. Desde esta perspectiva (una perspectiva consciente, inevitablemente europea), examinaré el protagonismo del lugar en varios poetas de Hispanoamérica, procurando ver cómo se ha luchado a lo largo del siglo XX por conseguir un discurso del arraigo que no necesariamente tenga miedo a las presiones supralocales de la vanguardia. Primero, sin embargo, habrá que adentrarse en las fuerzas literarias del desarraigo.

\section{El desarraigo de los decadentes: de Huysmans a Julián del Casal}

El poeta cubano Julián del Casal, el más decadentista de los modernistas hispanoamericanos, enfermo de tuberculosis y encerrado en su casa de La Habana, mantuvo una relación epistolar de buen discípulo con su maestro europeo, Joris-Karl Huysmans, cuyo $\grave{A}$ rebours (Contra natura) fue la obra paradigmática del decadentismo francés y fue leído con fervor en el Nuevo Mundo. Hasta Rubén Darío, uno de los modernistas menos decadentes, adoptó como pseudónimo Des Esseintes, el nombre del protagonista de la novela de Huysmans. La fascinación por este modelo (que se suma, claro está, a la admiración incondicional por otras figuras parisinas: Verlaine, Moreau, Gautier, etc.) es a la vez sintomática e impulsora del desarraigo que de pronto inundó la poesía hispanoamericana. Mientras la industrialización reparte por Occidente su asalto a la tierra, la literatura también, en un plano simbólico, atenta contra ella. Los «ecocríticos» de los últimos años no dejan de destacarlo: la relación del ser humano con su entorno se palpa siempre, de manera más o menos explícita —y hasta en su ausencia aparente—, en la literatura. 
El memorable Des Esseintes, un duque hiperrefinado y enfermizo que se ha hartado de la vulgaridad burguesa de París, decide refugiarse del mundanal hastío en las afueras de la ciudad, en un ambiente artificial de extravagante lujo que manda construir a su alrededor. Me gustaría comentar un aspecto aislado de este mundo. A su casa de esteta decadente, llega un día un «enorme escudo de oro» que sorprende al lector cuando empieza a mecerse hacia atrás y adelante, «dejando ver una cabeza de tortuga que, en un repentino ataque de pánico, volvió a meter bajo el caparazón» (Huysmans, 69). Des Esseintes había visto la tortuga en una tienda, nadando en un tanque de agua, y la compró para que hiciera juego con una alfombra oriental de colores iridiscentes. Ocurrió, sin embargo, que el caparazón le parecía tan oscuro que tuvo que devolver el reptil a la tienda para que lo sometieran a un baño de oro. Pero después de este nuevo trámite, tampoco le agradaba el resultado: al colocarla sobre la alfombra, «tuvo la sensación de que esta gigantesca joya estaba terminada sólo a medias y que no quedaría realmente completa hasta estar incrustada de piedras preciosas» (70). Y así fue, con resultados triunfantes. Des Esseintes no cabía en sí de tanta alegría: hasta se le despertó — cosa rara — el apetito.

No es casual, me parece, esta relación entre la tortura sufrida por la tortuga - que para el protagonista es un ornamento, una "gigantesca joya" cuyo sufrimiento le resulta absolutamente irrelevante- y el placer sensorial experimentado por su comprador. Tampoco es casual que el festín que Des Esseintes se prepara, para satisfacer su insólito ataque de hambre, desate, muy a su pesar —él intentaba evitar todo lo que "pudiera provocar pena o repugnancia» (79)_, una serie de recuerdos sobre «un espantoso dolor de muelas» que hace años sufrió y la consiguiente visita a un salvaje dentista. El esteta, cuyo desprecio por los demás seres vivos es intenso, al recordar su propio dolor de repente se humaniza —al fin y al cabo él, que se cree tan superior, sufre igual que todo el mundo-, e incluso - la yuxtaposición con la escena de la tortuga es fundamental— se animaliza: "Aferrado a los brazos del sillón, Des Esseintes sintió el frío contacto metálico en su mejilla, al tiempo que veía las estrellas, y, entre dolores terribles, empezó a patear y chillar como una bestia herida» (76, cursiva mía). Hay que recordar que estamos en Francia, donde la tradición cartesiana decretaba que un animal no es más que una máquina sofisticada. En palabras de Descartes: «sé muy bien que los animales hacen muchas cosas mejor que nosotros, pero no me extraña, pues precisamente eso sirve para demostrar 
que actúan natural y mecánicamente, como un reloj que indica mejor la hora que nuestro entendimiento. Y sin duda cuando las golondrinas vuelven en primavera, actúan al hacerlo como relojes» (Ferry, 62). Claro, el paso siguiente es breve, lógico e inexorable: el animal, como buena máquina o buena joya, será incapaz de sentir, gozar o sufrir. Después de emerger del recuerdo doloroso del dentista, Des Esseintes examina la tortuga y encuentra que está muerta: "Acostumbrada sin duda a una vida sedentaria, una humilde existencia transcurrida al abrigo de su modesta concha, no había sido capaz de soportar el deslumbrante lujo impuesto, la reluciente capa con que la vistieron, la pedrería empleada para decorar su caparazón como si fuera un ciborio» (Huysmans, 77). No es que haya sufrido, sino que ha sido indigna de tanta belleza, incapaz de apreciarla o tolerarla. No ha merecido seguir viva.

Lo interesante aquí, me parece, no es sólo la metáfora de la explotación de la naturaleza perpetrada por el hombre moderno, sino la total indiferencia sentida por el dolor y la muerte de la tortuga: ésta, acostumbrada, como ya se ha visto, a pasar la vida en un tanque de agua (un encarcelamiento, a fin de cuentas, menos feroz), después es desterrada, mejor dicho desaguada a una nueva y más terrible prisión, donde lo único que recibe de su nuevo amo es el encargo de un baño de oro. No creo que el novelista haya yuxtapuesto el sufrimiento de su protagonista y el de la tortuga para revelar, criticándola, la deshumanización de aquél. Sería, más bien, un lapsus inconsciente, porque Huysmans parece participar con Des Esseintes, empleándolo como alter ego, en el odio a la naturaleza y la celebración de lo artificial. Así se ve en el siguiente pasaje, que habría que leer, sin duda, como una declaración de principios estéticos:

Des Esseintes creía que el artificio era el rasgo distintivo del genio humano. Afirmaba que ya había pasado la hora de la naturaleza, que, con la fatigante uniformidad de sus paisajes y cielos, había agotado definitivamente la atenta paciencia de las personas refinadas y sensibles [...]. La naturaleza, iqué monótono almacén de prados y árboles, qué banal exhibición de mares y montañas! De hecho, no hay ni una sola de sus invenciones, estimadas tan sutiles y grandiosas, que el ingenio humano no pueda crear. El bosque de Fontainebleau, o un claro de luna, pueden ser reproducidos por decorados provistos de reflectores. Una cascada puede ser imitada a la perfección por la ingeniería hidráulica. No hay roca que el cartón-piedra sea incapaz de fingir, ni flor que un seleccionado tafetán, o un primoroso papel pintado, no puedan igualar. Indudablemente, la naturaleza, esa sempiterna vieja chocha, ha acabado ya con 
la confiada admiración de los verdaderos artistas, y ha llegado el momento de que sea reemplazada, siempre que sea posible, por el artificio. (53)

Esta desacralización y desprecio por la naturaleza se repite en Julián del Casal, quien celebró a Huysmans como el «alma más noble, más pura, más sensible, más dolorosa, más elevada, más excepcional»(Casal, 146). El discípulo cubano hace hincapié en la obsesión de su maestro por un dolor que él también comparte: «lo que seduce a Huysmans, bajo cualquiera forma, en cualquiera época y por cualquiera causa, es el sufrimiento. No siente el vértigo del mal, como impropiamente se ha dicho, sino el vértigo del dolor» (149). Junto con esta obsesión por el dolor (mejor dicho, quizá, por su propio dolor), Casal señala — parafraseando el párrafo citado arriba - que Huysmans «odia la Naturaleza, juzgándola como una gran artista agotada que no hace más que repetirse en sus obras, cuyas bellezas pueden ser fácilmente, no ya imitadas, sino superadas por el genio del hombre» (148). Él mismo repetirá estas ideas en su poesía. En su búsqueda de lo bello (del poema "A la belleza»), la Naturaleza será una madre infame de la que huye el hablante: «En brazos de la gran Naturaleza / de los que huí temblando / cual del regazo de la madre infame / huye el hijo azorado» (281). Y en el célebre «En el campo», profesará un «impuro amor de las ciudades» y una negación de la naturaleza:

Tengo el impuro amor de las ciudades, y a este sol que ilumina las edades prefiero yo del gas las claridades.

A mis sentidos lánguidos arroba, más que el olor de un bosque de caoba, el ambiente enfermizo de una alcoba. [...]

A la flor que se abre en el sendero, como si fuese terrenal lucero, olvido por la flor de invernadero.

Más que la voz del pájaro en la cima de un árbol todo en flor, a mi alma anima la música armoniosa de una rima.

Nunca a mi corazón tanto enamora el rostro virginal de una pastora, como un rostro de regia pecadora.

$\mathrm{Al}$ oro de la mies en primavera, yo siempre en mi capricho prefiriera el oro de teñida cabellera... (357) 
El rechazo del mundo «natural» es absoluto. Se podría hablar, sin duda, de las condiciones abyectas del campo cubano a finales del siglo XIX, y de todos los factores que hacen comprensible esta desmitificación conscientemente escandalosa de los tópicos pastoriles. Lo que quiero señalar, sin embargo, es cómo esta fascinación con la vida de la gran ciudad y esta fe en la capacidad del hombre moderno de prescindir de la "gran Naturaleza» - usurpando su papel creador, reemplazando lo natural por lo artificial-, equiparan la tendencia artística de los decadentistas con la tendencia destructora de la sociedad tecnologizada (se estaba tecnologizando, más bien, en esa época en Cuba), que ha acelerado sin freno desde entonces, desencadenando, en las últimas décadas, nuestra crisis ecológica sin precedentes. El arte también es responsable, aunque sea a nivel simbólico. También participa en el ecocidio.

\section{El desarraigo creacionista de Vicente Huidobro}

Vicente Huidobro, audaz pionero de las vanguardias, rompe con todo pero no con los principios antinaturales de los decadentistas: su temprano manifiesto Non serviam (1914) trata precisamente de una rebelión contra la «madre Natura», a la que describe, empleando el mismo adjetivo de Huysmans (recuérdese: el adjetivo que no da vida mata), como una «vieja chocha»: "Y ya no podrás decirme: “Ese árbol está mal, no me gusta ese cielo..., los míos son mejores". Yo te responderé que mis cielos y mis árboles son los míos y no los tuyos y que no tienen por qué parecerse. Ya no podrás aplastar a nadie con tus pretensiones exageradas de vieja chocha y regalona" (Huidobro, 653-654). En manifiestos posteriores, el paralelismo entre el progreso tecnológico moderno y lo que Huidobro veía también como un progreso poético, la superación del realismo - el Hombre-Espejo se convierte en Hombre-Dios, en un proceso que culmina, por supuesto, en el propio Huidobro: la poesía contemporánea soy yo, decía-, muestra el lado oscuro, perturbador de este alejamiento del mundo. La nueva poesía es otro artefacto más en el creciente dominio del ser humano sobre su medio: «El hombre ya no imita. Inventa, agrega a los hechos del mundo, nacidos en el seno de la Naturaleza, hechos nuevos nacidos en su cabeza: un poema, un cuadro, una estatua, un barco a vapor, un auto, un aeroplano...» (693). O bien: «El hombre ya ha inventado toda una fauna 
nueva que anda, vuela, nada, y llena la tierra, el espacio y los mares con sus galopes desenfrenados, con sus gritos y sus gemidos. Lo realizado en la mecánica también se ha hecho en la poesía» (673).

Esta fauna nueva, retratada en la violenta imaginería de sus «galopes desenfrenados», sus gritos y sus gemidos, en efecto llena la tierra. Para medir los alcances de la modernolatría huidobriana, habrá que contrastarla, quizá, con el despertar ecologista de Neruda en "Se llenó el mundo", del libro Fin de mundo (1969), que pinta desde una perspectiva apocalíptica las consecuencias ambientales de las creaciones modernas:

Hermosos fueron los objetos que acumuló el hombre tardío, el voraz manufacturante: conocí un planeta desnudo que poco a poco se llenó con los lingotes triturados, con los limones de aluminio, con los intestinos eléctricos que sacudían a las máquinas mientras el Niágara sintético caía sobre las cocinas.

Ya no se podía pasar en mil novecientos setenta por las calles y por los campos: las locomotoras raídas, las penosas motocicletas, los fracasados automóviles, las barrigas de los aviones invadieron el fin del mundo: no nos dejaban transitar, no nos dejaban florecer, llenaban arenas y valles, sofocaban los campanarios:

no se podía ver la luna.

Venecia desapareció debajo de la gasolina, Moscú creció de tal manera que murieron los abedules desde el Kremlin a los Urales y Chicago llegó tan alto que se desplomó de improviso como un cubilete de dados. 


\author{
Vi volar el último pájaro \\ cerca de Mendoza, en los Andes. \\ Y recordándolo derramo \\ lágrimas de penicilina. (2000: 453-454)
}

El detritus de lo artificial ha llenado y esquilmado la tierra, y el ser humano ha perdido el contacto tanto con la Naturaleza como con lo que sigue siendo, para Neruda, lo esencialmente poético: ya no se puede caminar (la crisis del peatón en las grandes ciudades); ya no se puede florecer (somos seres espiritualmente mutilados). Los campanarios sofocados hablan de esta misma muerte espiritual, mientras que la luna invisible (tapada, tal vez, por el smog de Santiago de Chile, México D.F., o de donde sea) y la muerte de los pájaros apuntan a la pérdida de dos símbolos centrales de la tradición poética de Occidente. Chicago (emblema de la industrialización capitalista), Venecia (emblema de la cultura europea) y Moscú (emblema de la utopía o ex-utopía marxista): son todos protagonistas de la degradación del planeta (y de la poesía). Y la agonía de la tierra - la extinción de los pájaros - avanza a la par que la alienación del hombre, enajenándolo hasta las lágrimas.

El lamento poético de Neruda contrasta notablemente con el impulso huidobriano - un impulso de espíritu tecnologista - de usar el espacio para recrear la naturaleza, recrearse con ella en el hallazgo de combinaciones nuevas, ingeniosas y a veces geniales. "Yo tengo derecho a querer ver una flor que anda o un rebaño de ovejas atravesando el arco iris» (Huidobro, 654), dice el poeta, celebrando así dos imágenes tan bucólicas en su materia prima y su tono como «avanzadas» en sus yuxtaposiciones. Pero en sus primeros libros vanguardistas, el tono bucólico desaparece y hay un largo repertorio de imágenes naturales, fundamentalmente de pájaros, desgarradas por la pérdida, el dolor, la mutilación o la muerte. El lector de Ecuatorial y de Poemas árticos (ambos de 1918) encontrará —voy a proceder cronológicamente, siguiendo el orden de los poemas - alas de golondrinas esparcidas por el suelo (294), un ruiseñor desafinado (297), un ruiseñor mecánico (302) y pájaros sin alas (306); encontrará un pájaro muerto (308), otro muerto en pleno vuelo (309), otro que ha perdido su camino (309), otro perdido en el humo de un cigarro (311), unas gaviotas que han perdido sus plumas (311), un ruiseñor que canta en vano (312), una alondra de nieve que «se me muere» (315), un pájaro que agoniza «en mi garganta» (316), un pájaro que se quema en el ocaso (317), un 
verso en que "todas las golondrinas se rompieron las alas» (322), una golondrina indiferente (323), de nuevo unas golondrinas sin alas (323), algunos pájaros «de ala inversa» que mueren entre las tejas (325), un ruiseñor que se queja en la memoria del poeta (326), el ruiseñor de las batallas que "canta sobre todas las balas" (326), un pequeño ruiseñor que murió y un pájaro que se quema día a día (330). O bien, en el francés de Automne régulier (de 1925), encontrará estos versos:

En vain tu cherches

Arbre d'automne

Il n'y a plus d'oiseaux

Il n'y a plus d'oiseaux. (331)

Ahora bien, los pájaros de Huidobro son en principio símbolos arquetípicos - la golondrina que simboliza el paso del tiempo, el ruiseñor que simboliza el canto, la alondra doblemente simbólica que tiene la gracia de cantar y volar a la vez, etc.—, que sugieren el estado de ánimo del hablante y de su época (la resaca después de la Gran Guerra). No obstante, se pueden leer, también, como imágenes testimoniales (a su pesar) o premonitorias de la destrucción ecológica: el poeta se aleja de la naturaleza, juega a descolocar sus componentes, mientras que la tecnología juega de verdad y está aniquilando el mundo natural. Los pájaros deformes, moribundos y extintos de Huidobro (il n'y a plus d'oiseaux) son vivas imágenes de este ecocidio.

Juan Larrea cuenta la siguiente anécdota: «en Octubre de 1932, Vicente [Huidobro] y Ximena [su esposa] salieron de París, él vestido de proletario, con un chaquetón y pantalones de pana. En Barcelona recogió unas parejas de ruiseñores que se proponía aclimatar en Chile» (Larrea, 255). Estamos frente a una más de las extravagancias de Huidobro - dandy de la alta aristocracia chilena, va vestido de obrero comunista-, pero no deja de ser simbólica o bien, mejor dicho, de trascender la anécdota esta obsesión por los ruiseñores, multitudinarios (aunque mutilados) en su poesía pero inexistentes en su país y en todos los países de América. Más de cuatro siglos antes, al acercarse Colón a las Indias, escribió que sólo faltaban los ruiseñores para completar el entorno paradisíaco, y cuando llegó por fin a las Antillas, ahí estaban los ruiseñores, y cantaban, claro que sí que cantaban. ${ }^{18}$ Ya se sabe: Colón pintaba el Nuevo Mundo con esquemas mentales forjados y esclerotizados por sus lecturas, 
y en éstas el ruiseñor representaba el paradigma de la belleza. Las autoridades culturales eran, para Huidobro también, europeas. Hombre de la periferia, él vivía su chilenidad como un lastre. Por eso, más allá de la bufonada, llevar ruiseñores a Chile significaría convertir a éste, simbólicamente, en un país europeo, un país digno de producir poesía y digno de haberlo producido a él. Desde luego, si realmente llegó a enviarlos, los ruiseñores se habrían muerto en el viaje, así como se mueren y mutilan en su poesía. ¿Por qué cantáis al ruiseñor, oh Poeta? Esta obsesión con lo ajeno y rechazo a lo propio, esta alienación galófila tan característica de Huidobro y sus hermanos modernistas (Darío y Casal, a su pesar), ¿no son síntomas inequívocos de la más profunda de las alienaciones? Una alienación doble: la de no sentirse bien en su piel, de querer ser otro; y más grave aún, la de aspirar a convertirse en otro (el europeo) que ya encarnaba todas las alienaciones del mundo moderno.

\section{Lenguajes universales y lenguajes arraigados (Gabriela Mistral, Jorge Teillier)}

Huidobro se jactaba de la universalidad de su obra, lo cual significaba para él que lo particular había sido desterrado de ella: «Si para los poetas creacionistas lo que importa es presentar un hecho nuevo, la poesía creacionista se hace traducible y universal, pues los hechos nuevos permanecen idénticos en todas las lenguas». El objeto creado, a diferencia de la música o el ritmo de las palabras, «no pierde en la traducción nada de su valor esencial» (Huidobro, 676). Juzgar a Huidobro por sus pronunciamientos teóricos más que por su práctica poética — que se escapaba, felizmente (a veces), de las imposiciones abstractas - resulta tan fácil como

18 Conocemos la transcripción y paráfrasis hecha por fray Bartolomé de las Casas. El 16 de septiembre de 1492, «dice aquí el Almirante que hoy y siempre de allí adelante hallaron aires temperatísimos, que era placer grande el gusto de las mañanas, que no faltaba sino oír ruiseñores»; el 29 de septiembre, «los aires eran muy dulces y sabrosos, que dice que no faltaba sino oír el ruiseñor»; y el 6 de noviembre, «vieron aves de muchas maneras diversas de las de España, salvo perdices y ruiseñores que cantaban y ansares» (Colón, 10; 16; 62). Esta edición del Diario de Colón lleva un hermoso prólogo de Gregorio Marañón, con el título «Ruiseñores en el mar». 
insatisfactorio, pero tal vez corresponda recordar que en esos mismos años el esperanto como lengua universal también estaba luchando por vencer a las particularidades. Hoy, la universalidad buscada por los esperantistas (creacionistas de primer orden, aunque carentes de la imaginación del chileno) nos suena más bien grotesca: ${ }^{19}$ si se hubiera propagado, habría significado, al nivel más básico de los seres humanos (su lengua), no la trascendencia de las particularidades sino su negación y aniquilamiento. Por eso, no es casual que Huidobro no haya hecho escuela con su movimiento: puede que el creacionismo sea suyo pero, definitivamente, la poesía contemporánea no es él.

Entre las corrientes opuestas a la huidobriana, destaca la de su compatriota y contemporánea, Gabriela Mistral, cuyo concepto del arraigo se relaciona no sólo con un lugar específico, sino con una lengua que es casi una emanación de ese lugar. Cuando la enviaron en 1918 como maestra a la ciudad de Punta Arenas, Mistral experimentó por primera vez, y con horror, la profundidad del vínculo con su pueblo natal y la expresó de forma memorable en el poema "Desolación", que da nombre a su primer libro e inicia la serie "Paisajes de la Patagonia». El yo del poema ha sido arrojado por el mar a un puerto del sur, a la «llanura blanca» de una tierra nevada que "no tiene primavera», y escucha cómo en torno a su casa un viento hostil hace una «ronda de sollozos / y de alarido, y quiebra, como un cristal, mi grito", mientras que por las tardes "miro morir inmensos ocasos dolorosos». El sentimiento de desarraigo se acentúa cuando ella se acerca a los marineros que llegan al puerto, buscando en ellos —en vanolos acentos de su tierra:

Los barcos cuyos velos blanquean en el puerto vienen de tierras donde no están los que son míos; sus hombres de ojos claros no conocen mis ríos y traen frutos pálidos, sin la luz de mis huertos.

19 Grotesca, pero también patética. Durante mi adolescencia londinense, pasaba cada día por delante de la Oficina central de Esperanto en Holland Park Avenue: una oficina grande, donde dos hombres esperaban en sus mesas, esperaban siempre, mudos y trajeados, a estudiantes hipotéticos que nunca llegaban. Como tantos sueños utópicos de la modernidad, el impulso del esperanto se fundaba en la filantropía — de ahí la prodigiosa fortuna capaz de mantener abiertas, todavía hoy, sus oficinas-. Y como tantos sueños de la modernidad, su fracaso es, a su manera, trágico. 
Y la interrogación que sube a mi garganta al mirarlos pasar, me desciende, vencida: hablan extrañas lenguas y no la conmovida lengua que en tierra de oro mi vieja madre canta. (2001: 106)

Los barcos agregan su blancura a la nieve que rodea al yo, apartándola aun más de la «tierra de oro» que anhela. La desolación aumenta al constatarse una separación insuperable: estos hombres de ojos claros —no de ojos oscuros, como los que viven en el Valle de Elqui, el oikos recurrente de la obra de Mistral - vienen de tierras que no son suyas; los frutos que traen son pobres sucedáneos de los frutos radiantes de la tierra de ella; y sobre todo, no hablan «la conmovida / lengua que en tierra de oro mi vieja madre canta». La lengua no es un instrumento impersonal para facilitar una comunicación utilitaria, ni una herramienta traducible y universal para divulgar hechos creados: al contrario, está cargada de una emoción que se vincula indisolublemente a un lugar específico, lugar que será siempre una radiante "tierra de oro" para sus habitantes, porque les pertenece, porque es suya. ${ }^{20}$ Como ese río de la aldea de Alberto Caiero, que era menos bello que el Tajo pero a la vez más bello que el Tajo, "porque o Tejo nâo é o rio que corre pela minha aldeia»; y era más libre y más grande que el Tajo, por ser poco conocido: «E por isso, porque pertence a menos gente, / é mais livre e maior o rio de minha aldeia» (Pessoa, 177-178).

Huidobro se enorgullecía de su ruptura con la Naturaleza: «Yo tendré mis árboles que no serán como los tuyos, tendré mis montañas, tendré mis ríos y mis mares, tendré mi cielo y mis estrellas. Y ya no podrás decirme: "Ese árbol está mal, no me gusta ese cielo..., los míos son mejores". Yo te responderé que mis cielos y mis árboles son los míos y no los tuyos y que no tienen por qué parecerse» (Huidobro, 653). Los posesivos de Huidobro, índices de su dominio sobre esta nueva naturaleza, son producto de un desarraigo que él persigue con voluntarismo iconoclasta: la mímesis vive de las particularidades imitadas; el creacionismo, en cambio, aspira a crear una naturaleza original, una nueva y maravillosa particularidad, que será la posesión exclusiva del poeta. Los posesivos de Mistral y de Caiero, por su parte, defienden la maravilla como algo arraigado en la experiencia de un

20 Compárese el poema 15 de la serie «Árboles» de Homero Aridjis: «De todos los árboles que crecen en la tierra, / ninguno como los de mi infancia: / el fresno, el oyamel, el trueno / y el que nace cada día» (1994: 435). 
lugar particular y real. Son parte de un oikos que les pertenece, pero al cual ellos también pertenecen; en cambio, mientras la naturaleza huidobriana pertenece al poeta, él no pertenece a nada, es libre (o pretende serlo), es autónomo (o pretende serlo) y sin duda es, con plenitud, moderno.

La conmovida lengua de Mistral es la lengua que «mi vieja madre canta», literalmente su lengua materna. La lengua materna se canta en torno a la cuna; las extrañas sólo se hablan. Quizá el rechazo de ese canto de la madre estuviera en la raíz de uno de otros tantos "profundos pensamientos» del alter ego de Huidobro, Altazor, cuando éste insistió en que «se debe escribir en una lengua que no sea materna» (Huidobro, 366). Por otro lado, como ya hemos visto, el poeta creacionista prometía en sus manifiestos hechos nuevos capaces de conservar su significado e impacto en todos los idiomas. Para ver lo absurdo de esta idea, basta con pensar en las distintas connotaciones del simple vocablo «río», tan sujetas a la experiencia particular del fenómeno "río" en cada lugar: ¿río Tajo o el río que corre por mi pueblo?, ¿río de mi tierra de oro o río de los extranjeros de ojos claros? El río de cada uno es un río preñado de experiencias personales, de convivencias y de mitos colectivos, y será siempre imposible traducirlo. Pensar lo contrario es volver al platonismo, a nociones centralizadas e impersonalizadas de un río-idea, y eso nos llevaría a una forma de alienación directamente relacionada con la literatura del desarraigo: pensar el río como idea, y asimismo, pensar el río como símbolo inamovible o metáfora muerta, delata una atrofia y mutilación sensorial que debe de ser fruto, en gran medida, de una sociedad resignada a la homogeneidad del espacio y que ha dejado de experimentar el entorno como un lugar único, irremediablemente particular. Un río es un río, o bien, una rosa es una rosa, como quería Gertrude Stein, pero sólo si uno cierra ojos, oídos, tacto y olfato a las particularidades de cada uno.

Jorge Teillier, quien proponía y practicaba una poesía de los lares, sostuvo que «el lujo del desarraigo se lo pueden dar sólo los pueblos antiguos, ya seguros de sí mismos. El cosmopolitismo es un lujo que puede darse sólo cuando se ha logrado [...] llegar al tiempo del arraigo verdadero» (1999: 4142). ¿Es así? ¿Conserva el cosmopolitismo español, británico, francés o alemán alguna pizca de un arraigo verdadero anterior a lo moderno? No lo creo. Cuando el poema «Traten de despertar» se refiere a «nosotros / los desterrados en un lugar en donde nadie conoce el nombre de los árboles» 
(2000: 64), toca una condición universal de la modernidad: los desterrados o dormidos son los desarraigados de todas las grandes ciudades modernas.

El discurso del desarraigo, al expulsar las particularidades del lugar, comienza con la pérdida de los nombres. Ver un árbol, una planta o un pájaro sin saber distinguirlo y nombrarlo, es, dada la limitadísima variedad de especies que habitan los ecosistemas cojos de nuestras ciudades contemporáneas, quizá el signo más revelador de nuestra alienación: el finísimo cordón umbilical que sigue ligándonos a la «naturaleza» deja indiferentes a los seres urbanos. El campo existe como vía de escape para el fin de semana, pero funciona más como espacio anónimo de ocio, apéndice vitalizador de la ciudad, que como conjunto de lugares particulares. Porque los lugares son, en esencia, eso: espacio particularizado.

Tan alienante como la pérdida de los nombres es su perduración sólo como figuras o símbolos literarios, desprendidos del referente original. Según una anécdota muy conocida, Francisco Villaespesa le preguntó a Unamuno el nombre de ciertas flores que había visto en el estanque del Retiro madrileño: "son nenúfares», habría respondido con sorna el salmantino, «esas flores que decoran tantos poemas tuyos». La ignorancia de Villaespesa es síntoma de una carencia experiencial totalmente común para un poeta urbano. Lo ha señalado el mexicano David Huerta: «No conozco muchos nombres de flores. Mejor dicho, conozco muchos nombres de flores que no puedo poner en contacto con las imágenes o las realidades concretas que esos nombres señalan. Sé que es una deficiencia (y hasta una falla grave) pero me ha tocado ser un poeta "urbano" (FornsBroggi, 228).

Pero el poeta urbano no está cercenado del todo de la naturaleza: la reconversión del espacio homogéneo de la gran ciudad en lugares, con sus propios rasgos y tradiciones y lenguajes, es un reto y un paso tal vez obligatorio en la lucha por recuperar un sentido de arraigo. Coleridge, al escribir sobre las intenciones de Wordsworth en Lyrical Ballads, ofreció una visión insuperable de la función desfamiliarizadora de la poesía (no sólo de la poesía romántica), como fuente de renovación poética, pero sobre todo - tratándose de una función, o al menos de una aspiración social— como forma de despertar a los lectores a un mundo que les había sido encubierto por las telarañas de la rutina: 
Mr. Wordsworth, en cambio, se propondría el objeto de dar el encanto de la novedad a las cosas cotidianas y de excitar un sentimiento análogo a lo sobrenatural, al despertar la atención mental del letargo de la costumbre y dirigirla hacia la hermosura y las maravillas del mundo ante nosotros, un tesoro inagotable para el cual, en consecuencia de la pátina de la familiaridad y de nuestras inquietudes egoístas, tenemos ojos pero no vemos, oídos que no oyen, y corazones que ni sienten ni comprenden. (Coleridge, 114)

Presos del narcisismo y del egoísmo, es probable que nuestra toma de conciencia ecologista, cuando ocurra (si llega a ocurrir), se produzca sólo por motivos de narcisismo y de egoísmo, es decir, porque la materialidad de sus secuelas nos llegue a atañer directamente. Abrir ojos, oídos y corazones podrá servir para anticipar la toma de conciencia, para superar la indiferencia actual por el futuro, pero implicará también, necesariamente, una toma de conciencia lingüística, un reaprendizaje de los nombres de los lugares que habitamos y de las cosas entre las que vivimos. En "Las ostras», un poema que comentaré más tarde, José Emilio Pacheco ofrece una viva imagen de esta alienación nuestra respecto a las cosas y los nombres, y combate la ciega comodidad de nuestra actitud con una poética de la «atención enfocada», no tan lejana de la de Coleridge, que sería capaz de despertarnos y hacernos comprender — con ojos ecologistas de fin de siglo_ el papel de la especie humana y de las comunidades humanas como "parte infinitesimal» de un vasto ecosistema que está al borde del abismo (1996: 97).

La conciencia de la pérdida o del fin inminente siempre agudiza las sensibilidades. Está ahí en Jorge Teillier, cuya definición de la poesía lárica, en los años sesenta, se enfrentó al discurso del desarraigo dominante entre los escritores urbanos de Santiago de Chile. Teillier insistió en la necesidad de integrarse en un lugar donde "no se siente solo, sino siempre rodeado de un mundo físico al cual pertenece y que le pertenece, y de antepasados que lo acompañan en su tránsito terrestre» (1999: 23). El poeta, sabiéndose parte de algo más grande que lo trasciende, tiene la responsabilidad de preservar el legado - la sabiduría, las costumbres, las tradiciones - de todos los que han vivido en su lugar. Como apoyo fundamental a estas ideas, Teillier cita, en los dos ensayos teóricos más importantes de su obra, las mismas palabras de Rilke:

Para nuestros abuelos, una torre familiar, una morada, una fuente, hasta su propia vestimenta, su manto, eran aún infinitamente, infinitamente más familiares; cada cosa era un arca en la cual hallaban lo humano y agregaban su ahorro de humano. He aquí que hacia nosotros se precipitan, llegadas de América, cosas 
vacías, indiferentes, apariencias de cosas, trampas de vida... Una morada en la acepción americana, una manzana americana, o una viña americana nada de común tienen con la morada, el fruto, el racimo en los cuales habían penetrado la esperanza y meditación de nuestros abuelos... Las cosas dotadas de vida, las cosas vividas, las cosas admitidas en nuestra confianza, están en su declinación y ya no pueden ser reemplazadas. Somos tal vez los últimos que conocieron tales cosas. Sobre nosotros descansa la responsabilidad de conservar no solamente su recuerdo (lo que sería poco y de no fiar), sino su valor humano y lárico. (26; 65)

Esta imagen de lo norteamericano nos puede resultar tópica en su jerarquización moral tan marcada, pero más allá de los tópicos —o bien abrazándolos-, ¿qué duda cabe hoy de que la todavía creciente y alienante homogeneidad de los grandes centros urbanos significa sobre todo una norteamericanización del mundo? Según Rilke y Teillier, frente a las tendencias globalizadoras el valor humano y lárico de las cosas y las palabras particulares seguirá palpitando durante tiempos de penuria espiritual, como antídoto catártico y como recuerdo de otras posibilidades, a la manera de esos libros guardados en la memoria de los fugitivos de Fahrenheit 451, la novela de Ray Bradbury tan querida por Teillier.

\section{Topónimos en la poesía (Pablo Neruda, María Mercedes Carranza)}

Conocer un árbol por su nombre es verlo en su particularidad, digamos, de plátano oriental o de árbol de Judas, y no como variación más o menos indiferenciada del árbol genérico, del árbol-idea. Nombrar algo es verlo, sentirlo. Al caminar por la rosaleda del Parque del Oeste madrileño, los sentidos se despiertan y se agudizan a ver cómo la rosa no es una sola sino muchas rosas, cada una con sus propios matices. El profesor universitario, enfrentado por primera vez a los cien alumnos de una nueva clase, ve una masa indiferenciada de rostros hasta que poco a poco, en calladas aproximaciones onomásticas («la del piercing», «el de la coleta», «la que se sienta en primera fila a la derecha») y luego con el aprendizaje de los nombres, los van diferenciando y convirtiendo en individuos, en seres particulares.

Desde la perspectiva de las grandes ciudades — quiero decir, desde la perspectiva de los que no han conocido la vida fuera de la gran ciudad-, el campo también carece de particularidades. Pero este cambio moderno 
en la noción del campo va más allá de un empobrecimiento de la mente urbana: las emigraciones a la gran ciudad despueblan las aldeas, las vacían de jóvenes y rompen los ciclos regeneradores de la vida campesina; por otro lado, los mass media y las nuevas tecnologías homogeneizadoras también han alcanzado los pueblos. Ésta es, desde luego, la historia de la modernidad. El arraigo de las pequeñas comunidades, tantas veces exaltadas con el blando sentimentalismo de una falsa nostalgia, significaba para los primeros modernos no tanto seguridad y tradición y pertenencia como una asfixiante camisa de fuerza: desarraigarse del pueblo, emigrar a la gran ciudad, olvidarse de las cosas y los nombres del campo, fue una liberación. Conviene recordarlo. No se trata de glorificar, ni de proponer regresos escapistas a un pasado inexistente. Se trata, eso sí, de la cuestión de cómo vivir y cómo escribir en un mundo que posiblemente esté a punto de reventar ecológicamente por falta de previsión y por los gozosamente disfrutados excesos de nosotros, los privilegiados. Como posible respuesta, aferrémonos a los vestigios de los tiempos de arraigo.

El desarraigo empieza con el olvido de los nombres. Luchar contra el olvido, para un poeta, es convocar nombres abandonados o en peligro de abandono. A finales de 1914 y a los treinta y seis años, el articulista anglo-galés Edward Thomas empezó — febril, torrencialmente - a escribir poemas contra el trasfondo, a menudo mudo o borroso, de la Gran Guerra. Thomas, que intuía quizá lo que sería el impacto en el campo inglés de las nuevas tecnologías (tecnologías que se ensayaban, a su manera, en la guerra) y sabía también la inminencia de su propia participación en el conflicto, hablaba en estos textos, sin sentimentalismos bucólicos, de la flora, la fauna y las pequeñas comunidades de su entorno. Su poema más conocido, "Adlestrop», surge de una palabra, el nombre de un pueblo leído por el hablante - y luego recordadocuando su tren se detiene inesperadamente en una estación desierta:

\footnotetext{
Yes. I remember Adlestrop -

The name, because one afternoon

Of heat the express-train drew up there

Unwontedly. It was late June.
}

El topónimo, en su torpe pero entrañable sonoridad (What I saw / Was Adlestrop -only the name), se convierte en emblema de toda una forma de vida anclada en dos condados del corazón de Inglaterra: 
And for that minute a blackbird sang

Close by, and round him, mistier,

Farther and farther, all the birds

Of Oxfordshire and Gloucestershire. (Thomas, 48)

Gracias al nombre del pueblo, junto al canto del mirlo y a las plantas que el hablante observaba desde el tren y ahora nombra, el pequeño pueblo de Adlestrop ha adquirido una existencia poética inesperada, acaso más fuerte y duradera que su existencia real.

Saber que Thomas partió a la Guerra en julio de 1915 y que murió en enero de 1917 hace del texto una especie de despedida personal a la campiña inglesa que el poeta tanto quería. Pero también es una despedida, en términos más generales, a una forma de vida que sería radicalmente alterada en las décadas siguientes por la emigración a Londres, y por los nuevos métodos y necesidades de la agricultura, el progreso tecnológico que terminaría extinguiendo a tantas especies locales y cerrando la estación de Adlestrop. «Sí, yo recuerdo Adlestrop»: el recuerdo connota una pérdida, y el eco resonante del nombre evoca, tal vez mejor que cualquier descripción, el lugar, la pequeña comunidad, los lares que latían invisibles tras la estación.

Proust ya había disfrutado del poder evocador de los nombres de los pueblos que pasan, efímeros, ante los ojos del viajero. En la última parte de Por el camino de Swann, "Nombres de tierras: el nombre», el narrador habla con intensa emoción de un posible viaje en tren que lo llevaría a pasar la noche «en uno de aquellos pueblos por donde pasaba el tren, el que nosotros quisiéramos escoger, porque paraba en Bayeux, Coutances, Vitré, Questambert, Pontorson, Balbec, Lannion, Lamballe, Benodet, Pont Aven y Quimperlé, e iba avanzando con esa magnífica carga de nombres que me ofrecía, y de los cuales no sabía yo elegir porque me era imposible sacrificar ninguno" (Proust, 323). Producto de la sonoridad y las connotaciones verbales o culturales, surgía de cada nombre la imagen de un lugar rebosante de sugerencias. Resulta paradójico que el viaje en esta máquina moderna, que ya en sí era agente de la destrucción de los pueblos más pequeños, haya permitido vislumbrar o intuir la peculiaridad de unas formas de vida en vías de extinción, y que haya podido despertar y encandilar la imaginación de tantos viajeros. Así, en Crónica del forastero (1968) de Jorge Teillier, el hablante recuerda con emoción sus primeros viajes en tren: 
Te dejaron subir a la locomotora.

Hay que amar a la locomotora como a un gran animal doméstico, amar sus resoplidos, sus nubes de vapor,

la lluvia de hollín con que te bautiza cada estación.

$[\ldots]$

Te asomas alarmado a la ventanilla del vagón.

Tu padre bajó al andén para hablar con un amigo, temes oír de un momento a otro el silbato de partida.

Empiezas a conocer los pueblos de la Frontera.

Tienen nombres que en la lengua de la Tierra

quieren decir: «Guanaco echado», «Río de brujos», «Lugar de cenizas». (Teillier, 88)

Esta entrañable locomotora permitió al poeta-niño descubrir la región de la Frontera en que vivía, y conocer sus pueblos a través del primer contacto con los nombres, aquí traducidos de la original «lengua de la Tierra» - lengua de los Mapuches: Mapu=tierra, Che=gente-, arraigada desde siempre en la zona y vinculada de manera sagrada a la Tierra madre. Son nombres cargados del pensamiento mágico de las sociedades indígenas. Pero el tren estaba vaciando los pueblos, facilitando la emigración de los jóvenes hacia la capital. El propio poeta lo dice: «Vuelvo a 1953, cuando como todo provinciano debí hacer el viaje bautismal de hollín de los trenes de entonces a Santiago, atravesando la noche como en un vientre materno hasta asomarse a la lívida madrugada de boca amarga de la Estación Central» (1999: 60).

Esta seducción de los nombres ya había llegado a Neruda, nacido como Teillier en la Frontera chilena, como cuenta en sus memorias:

El tren recorría un trozo de aquella provincia fría desde Temuco hasta Carahue. [...]. Cada estación tenía un nombre más hermoso, casi todos heredados de las antiguas posesiones araucanas. Ésa fue la región de los más encarnizados combates entre los invasores españoles y los primeros chilenos, hijos profundos de aquella tierra. Labranza era la primera estación, Boroa y Ranquilco la seguían. Nombres con aroma de plantas salvajes, y a mí me cautivaban con sus sílabas. Siempre estos nombres araucanos significaban algo delicioso: miel escondida, lagunas o río cerca de un bosque, o monte con apellido de pájaro. (1988: 24-25)

Para Neruda, también, los nombres sirven para conocer los lugares. Revelan su esencia; tienen sabor, olor y misterio. Ver la evolución de los topónimos en Neruda es entender, en cierto modo, el cambiante lugar de los lugares en la poesía del siglo XX. Hasta los últimos poemas de su gran libro Residencia en la tierra (1935), un espacio hostil y anónimo aislaba al hablan- 
te, sumergiéndolo en su angustia, en la alienación absoluta de su entorno: "Me rodea una misma cosa, un solo movimiento» (1999: 261); «la tinta del trigo, del marfil, del llanto, / las cosas de cuero, de madera, de lana, / envejecidas, desteñidas, uniformes, / se unen en torno a mí como paredes» (262). Y cuando el espacio se representa con rasgos ligeramente más particulares, el resultado aumenta aún más la angustia y asfixia vital: seres sin nombres, homosexuales, muchachas amorosas, «largas» viudas, «jóvenes señoras preñadas hace treinta horas» y roncos gatos rodean la «residencia solitaria» del hablante "como un collar de palpitantes ostras sexuales» (285); asimismo, los elementos urbanos que pueblan «Walking Around» —sastrerías, cines, peluquerías, mercaderías, ascensores, zapaterías, paraguas y oficinas - funcionan metonímicamente para señalar la fragmentación radical de la gran ciudad, de cualquier gran ciudad, la imposibilidad de encontrar allí un sentido válido o humano para la vida (308-309). Sólo en los últimos poemas del libro puede percibirse un anclaje en un lugar o tiempo particular: en la «Oda a Federico García Lorca», el poeta-hablante nombra no sólo a su amigo, sino a todos los amigos que lo acompañan en España, desde Oliverio (Girondo) a Concha Méndez (333); en "Alberto Rojas Giménez viene volando», nombra a su amigo chileno muerto, cuyo vuelo lo lleva sobre un Valparaíso que también se nombra (337); y en el último poema del libro, "Josie Bliss», se pone nombre a la mujer birmana que estuvo, según los críticos, a la raíz de gran parte de los textos y de las angustias del libro (344).

Pero a partir de España en el corazón (1937), los lugares cobran un protagonismo central en Neruda. "Madrid is the heart» escribió W.H. Auden en «Spain», uno de los grandes poemas de la guerra civil española, y al haberse encontrado Neruda en ese Madrid, a gusto como nunca en su vida, sus nuevos textos, tan heridos por la guerra como novedosos en su obra, se sitúan explícitamente allí en el corazón herido del planeta. El poema más conocido del libro, "Explico algunas cosas», construye - ya en tiempo pasado- un mundo idílico centrado en un barrio que será luego, en la segunda parte, diezmado por los bombardeos. El texto se llena de particularidades: se nombra el barrio («mi barrio de Argüelles»), la casa ( $\mathrm{Mi}$ casa era llamada / la casa de las flores») y a los amigos (Rafael, Raúl, Federico). En poemas anteriores, como «Walking Around», los fragmentos de la vida urbana - jardines, mercaderías, anteojos, ascensores- y del mismo cuerpo humano - «Sucede que me canso de mis pies y mis uñas I y mi pelo y mi sombra» - connotaban una enfermedad intrínseca, una 
profunda alienación de la vida de la gran ciudad. Los fragmentos ya no representan el horror de la dispersión; al contrario, se congregan, se reúnen con plenitud en un todo armonioso, desbordante de vida. Las mercaderías han dejado de amenazar: sirven para entregar en abundancia los productos esenciales de la vida — «sal de mercaderías, / aglomeraciones de pan palpitante», aceite, "pescados hacinados», el «delirante marfil fino de las patatas» y los «tomates repetidos hasta el mar»—; asimismo, en las referencias a partes corporales, no hay aquí ese desmembramiento alienante de "Walking Around», la insidiosa pérdida de humanidad instalada en el cuerpo mismo, sino un indicio de la multitud solidarizada. «Un profundo latido / de pies y manos llenaba las calles»: es la unión de los hombres y mujeres que caminan por las calles, forman parte de las calles, y juntos constituyen ese corazón (Madrid is the heart) cuyo latido se divulga a lo largo del mundo. La estructura del poema funciona, desde luego, para construir una imagen de la ciudad republicana como un paraíso perdido, porque la Casa de las Flores ya no existe en el presente ( $« \operatorname{mirad} \mathrm{mi}$ casa rota»), el amigo Federico ha muerto («Federico, te acuerdas / debajo de la tierra?»), y las calles donde la vida latía han sido ahora ensangrentadas: "y por las calles la sangre de los niños / corría simplemente, como sangre de niños». La presencia de la sangre por estas calles particularizadas y nombradas (calles de «mi barrio de Argüelles») será el motor del cambio de la poesía nerudiana, tal como se proclama en los últimos versos del texto, versos citados hasta la saciedad, retóricos con la retórica grandilocuente y patetista de tanta poesía política, pero que resultan, gracias a ese lugar feliz construido y luego reventado por el poema, todavía conmovedores:

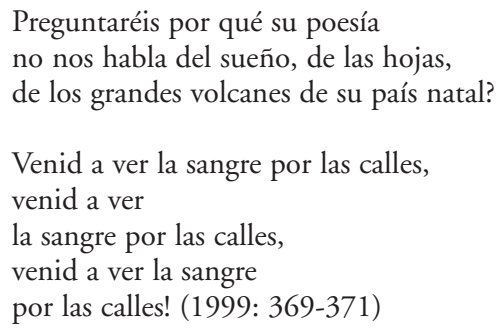

Con España en el corazón, Neruda ha entrado en el reino de los nombres particulares: nombra a sus amigos muertos; y nombra y condena a los "generales traidores», como seguiría haciendo más tarde con los conquis- 
tadores y los tiranos en Canto general. La tarea de nombrar se lleva al paroxismo en «Cómo era España», un poema cuyos últimos 68 versos son una lista de pueblos españoles:

\author{
Huélamo, Carrascosa, \\ Alpedrete, Buitrago, \\ Palencia, Arganda, Galve, \\ Galapagar, Villalba. \\ Peñarrubia, Cedrillas, \\ Alcocer, Tamurejo, \\ Aguadulce, Pedrera, \\ Fuente Palmera, Colmenar, Sepúlveda. \\ Carcabuey, Fuencaliente, \\ Linares, Solana del Pino, \\ Carcelén, Alatox, \\ Mahora, Valdeganda. [...] (1999: 374)
}

A través de estos nombres, de este conjunto que funciona «con la eficacia de una poderosa letanía, con la gravedad de una salmodia» (Sainz de Medrano, 88), Neruda intenta esbozar una definición del país, una respuesta a la pregunta del título de "cómo era España». Luis Sainz de Medrano compara el texto nerudiano con el poema 274 del Cancionero de Unamuno, que practica la misma enumeración de topónimos: «Ávila, Málaga, Cáceres, / Játiva, Mérida, Córdoba, / Ciudad Rodrigo, Sepúlveda, / Úbeda, Arévalo, Frómista / [...] / Sois nombres de cuerpo entero, / libres, propios, los de nómina, / el tuétano intraductible / de nuestra lengua española!» (Unamuno, 249). Huidobro aspiraba a una poesía traducible y universal; Unamuno, en cambio, sabe que es imposible traducir el tuétano de una lengua, y busca por ello una poesía intraductible y particular, con la conciencia de que el anhelo del arraigo y de la particularidad es en sí una aspiración intrínseca de los seres humanos y quizá, por tanto, universal. Nombres que son el tuétano de la lengua, lugares que son la esencia de la patria: no es casual que el poema citado se feche en julio de 1928, es decir, durante el destierro de Unamuno en Hendaya. Poner nombres es conservar lo particular, retener lo perdido, y volverá a ello el poeta en otros textos del Cancionero, como el 270: «Ebro, Miño, Duero, Tajo, / Guadiana y Guadalquivir, / ríos de España, ¡qué trabajo / irse a la mar a morir!» (248). 
Para Neruda, nombrar fue en primer lugar fijar en la memoria poética el barrio, su barrio de Argüelles; y en "Cómo era España», hace lo mismo con pueblos españoles que habían sido desgarrados por la Guerra Civil. La guerra moderna es (como la ciudad moderna, pero con otro ritmo) una gran niveladora y homogeneizadora: una bomba borra, con pasmosa facilidad, los edificios antiguos y simbólicos de un lugar, y con ellos la memoria material. Dentro de este contexto, un contexto inaudito para España, cada pueblo nombrado - Huélamo, Carrascosa, etc. - suena y resuena a comunidad orgánica escindida y destrozada: ¡el tuétano intraductible de la lengua española? Verbalmente intactos, los lugares detrás de los nombres ya no existían, ya no podrían existir como antes. La larga enumeración tiene algo de lamento, pero también, en su lúgubre flujo, un eco de ritos mágicos, encantatorios, empeñados no sólo en rescatar del tiempo a lo perdido, sino en restituirlo: «Fuenteovejuna, Alpedrete, / Torrejón, Benaguacil, / Valverde de Júcar, Vallanca, / Hiendelaencina, Robledo de Chavela. // Miñogalindo, Ossa de Montiel, / Méntrida, Valdepeñas, Titaguas, / Almodóvar, Gestaladar, Valdemoro, / Almoradiel, Orgaz» (1999: 376).

En el libro El canto de las moscas (1997) de la colombiana María Mercedes Carranza, cada uno de los veinticuatro cantos lleva por título el topónimo de un lugar que ha sido arrasado en los últimos años por la guerra civil colombiana: son nombres, muchos de ellos indígenas, que preludian escuetas viñetas de desolación, y que frente a éstas reverberan con todo el poder evocador de las historias y las tradiciones locales que se han perdido. El primer canto se llama «Necoclí»:

\author{
Quizás \\ el próximo instante \\ de noche tarde o mañana \\ en Necoclí \\ se oirá nada más \\ el canto de las moscas. (Carranza, 13)
}

El canto de las moscas que sirve como título al libro, matizado por ese "quizás» que denota fatalidad, inminencia de lo señalado, o acaso un resquicio de esperanza para que no ocurra, llegaría a sustituir, si prevaleciera, al canto de los seres humanos que poblaban y acaso todavía pueblan Necoclí, y al canto también de los pájaros que con ellos convivían y tal vez todavía convivan. El zumbido monótono e ininterrumpido de las moscas, con- 
gregadas en torno a los cadáveres de la guerra, es un canto de la tierra, sin duda, un signo de que los procesos naturales siguen pese a todo con sus ciclos imparables, pero éstos son o serán en Necoclí ciclos despojados de la biodiversidad, sin seres humanos y sin pájaros cantores. Frente a este horror, el topónimo indígena parecería, en sí, aludir con nostalgia involuntaria a un lugar de otras épocas, integrado en su ecosistema, ajeno a la depredación ecocida del colonizador europeo. ${ }^{21}$

Mientras en «Necoclí» la amenaza de destrucción se proyecta todavía hacia el futuro, el segundo canto del libro, «Mapiripán», habla de una defunción:

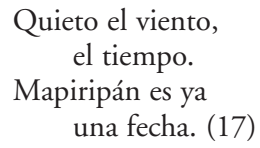

Si la memoria de un pueblo o una comunidad indígena se pierde míticamente en el pasado precolombino y teje los acontecimientos dentro de la red de su intemporalidad, aquí el tiempo histórico ha vencido al mito, reduciendo Mapiripán a una fecha concreta (la fecha de su defunción), y a un nombre que perdurará con toda la fragilidad desafiante de lo que la poesía nombra.

El canto de las moscas es una letanía, un catálogo de lugares muertos o moribundos («Entre el cielo y el suelo / yace / pálida Barrancabermeja. / Diríase / la sangre desangrada» [33]). Nutriéndose, como siempre, de lo muerto, los procesos naturales continúan sembrando sus ciclos en «ojos florecidos» (29), en las bocas de los muertos que aparecen en las corolas (81), en el pájaro negro que "husmea / las sobras de / la vida» (105). La tierra y la naturaleza prosiguen, aparentemente indiferentes al sufrimiento humano: el río de Dabeiba es dulce, pero las rosas rojas que lleva no son rosas sino sangre (25); hay otros ríos rojos (de nuevo, se entiende, de sangre), repletos de garzas blancas (73); y la tierra posee los restos humanos con la plácida laboriosidad de siempre: «Esto es la boca que hubo, / esto

21 "Ante el desenfreno destructor y el irrespeto al entorno natural de la mente eurocéntrica, la literatura ecologista hispanoamericana presenta como alternativa la visión de las culturas precolombinas del continente, destacando, en mayor o menor grado, sus propuestas de comunión natural entre todo lo que, además del hombre, habita este planeta» (Paredes y McLean, 27). 
los besos. / Ahora sólo tierra: tierra / entre la boca quieta» (37). Pero también sufre la tierra: si el ser humano vivía en comunión con su entorno, su repentina ausencia desencadena una serie de trastornos en el ecosistema, como la huida (también simbólica) de los pájaros cantores y como la solitaria, quemada flor del páramo que aguanta tenazmente de pie en "Vista hermosa» (una vista ya vista por nadie salvo el hablante), sugiriendo, en irónico contraste con el topónimo, los alcances ecológicos del horror:

$$
\begin{aligned}
& \text { El alto tallo } \\
& \text { espectral, } \\
& \text { quemada, yerta, } \\
& \text { solitaria } \\
& \text { flor del páramo. } \\
& \text { Así } \\
& \text { Vista Hermosa. (53) }
\end{aligned}
$$

\section{El sentido de arraigo (Ernesto Cardenal, José Emilio Pacheco)}

En Writing for an Endangered World, Lawrence Buell indaga «el lugar del lugar» en la literatura y la cultura contemporáneas, y defiende el sense of place, el sentido de arraigo que tenemos los seres humanos, como un factor central en la defensa de los ecosistemas amenazados: «mientras más se sienta un sitio como lugar, mientras con más fervor se aprecie, más grande será la preocupación potencial por la violación o incluso por la posibilidad de violación de ese sitio" (2001: 56). ${ }^{22} \mathrm{El}$ modelo tradicional del lugar consiste en un punto céntrico: alejarse del centro significa adentrarse progresivamente en lo ajeno, enajenarse. Es precisamente este modelo el que ha disminuido en la dispersión de la vida moderna. Sigue presente, sin embargo, en la mitificación de comunidades todavía incontaminadas, como el Montegrande de Gabriela Mistral, y en las reinvenciones de una edad de oro en poetas como Teillier. Algunos, como Raymond Williams (1985), tildan la idealización y mitificación de las comunidades orgánicas del pasado de alienante y escapista; pero esta idealización resulta espiritual

22 Los «ecocríticos» han hecho hincapié en esta necesidad de recuperar un sentido de arraigo en la literatura. Así, John Elder habla del "proceso de localización» en la poesía, mediante el cual «la poesía también deviene una manifestación del paisaje y del clima, de la misma manera que la flora y la fauna del ecosistema. Una voz humana deviene la voz de un lugar» (Elder, 39). 
y culturalmente necesaria, quizá un acto de auto-defensa instintiva en una sociedad urbana que está conduciéndonos por un callejón sin salida:

La idealización de las comunidades supuestamente orgánicas del pasado, como la idolización de los pueblos aborígenes que supuestamente han evitado los males de la modernidad, puede servir a menudo como una máscara para las opresiones del presente. Pero el mito de una vida mejor ya pasada no es menos importante por ser mito en vez de historia. Los mitos son imágenes necesarias, relatos ejemplares que ayudan a nuestra especie a dar sentido a su lugar en el mundo. Los mitos duran mientras cumplen alguna función útil. El mito de la vida natural que manifiesta los males de nuestra propia condición es tan antiguo como Edén y Arcadia, tan nuevo como el poema «Going, Going» de Philip Larkin y como la última adaptación en Hollywood de Jane Austen o Thomas Hardy. Tal vez haya que recordar lo que «se está yendo, se está yendo» como un mecanismo de supervivencia, como un control sobre nuestro instinto de auto-avanzamiento. (Bate, 25-26)

No obstante, la idealización no es la única forma de enfrentarse poéticamente al lugar, como señaló José Emilio Pacheco en su definición de la poesía como atención enfocada. Al mexicano le interesa una mirada capaz de dar cuenta de nuestra participación en la complejísima red de la vida, una participación siempre situada. De ahí se llega poéticamente a la superación de un concepto simplista y anti-ecológico de la autonomía del ser humano. No se trata de buscar lo pintoresco de un lugar; interesa, más que una simple descripción, la comprensión.

La poesía de Ernesto Cardenal explora, de manera ejemplar, las innumerables relaciones que conforman la red de la vida. Cántico cósmico (1992) es una vasta obra de celebración de la vida, y especialmente de la vida humana, pero siempre como parte de procesos cósmicos y microcósmicos complejísimos. Ya en 1963, en Gethsemany, Ky., una serie de textos escritos desde las experiencias de Cardenal en el monasterio trapense dirigido por el poeta Thomas Merton en Kentucky, se percibía la atención enfocada y ecológicamente despierta del nicaragüense:

Ha llegado al cementerio trapense la primavera, al cementerio verde de hierba bien rozada con sus cruces de hierro en hileras como una siembra, donde el cardenal llama a su amada y su amada responde a la llamada de su rojo enamorado.

Donde el reyezuelo recoge ramitas para su nido y se oye el rumor del tractor amarillo al otro lado de la carretera, rozando el potrero. 


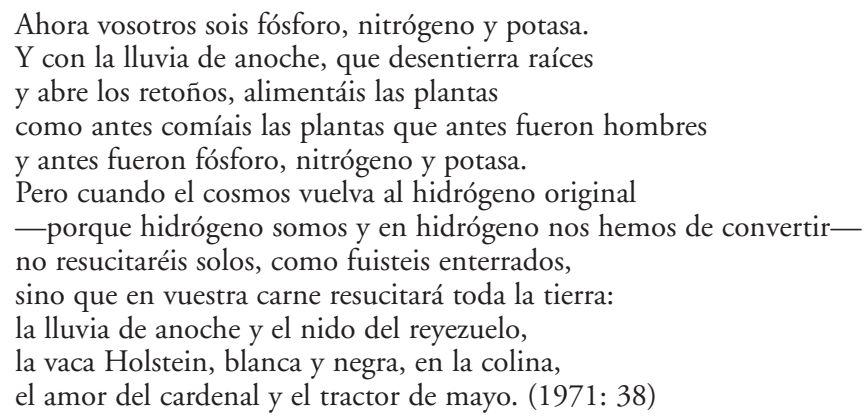

Vida y muerte, amor y muerte, se entretejen aquí como en tantos poemas pero partiendo de una visión concreta del lugar y también de un conocimiento de los comportamientos ornitológicos y de los procesos bioquímicos que funcionan por debajo y más allá de lo meramente pintoresco. La escena poetizada presenta una intrincada convivencia de la comunidad humana con la naturaleza no humana: el tractor ha sido humanizado para señalar su pertenencia al entorno (es un tractor amarillo, un "tractor de mayo" cuyo ruido es un "rumor» y cuyo tacto es suave mientras pasa «rozando» el potrero). Al apostrofar a los muertos, el yo del poema muestra que ellos en realidad siguen vivos, alimentando plantas que antes fueron hombres, participando plenamente en los grandes ciclos de la vida y la muerte, que son siempre ciclos de vida.

Enfocar la atención implica ir más allá de la descripción, entender los procesos subyacentes y estructurales. Significa también darse cuenta de la historicidad de los lugares. Para Buell, esta conciencia de la historicidad da una nueva dimensión al sentido de arraigo, abriéndolo no (sólo) a las herencias míticas sino al proceso de cambios que ocurre en cualquier lugar a lo largo del tiempo: «los lugares en sí no son entidades estables y autónomas, sino que están siendo constantemente formados y reformados por fuerzas tanto internas como externas. Los lugares tienen historias» (2001: 67).

Esta visión de la historicidad de los lugares, presente en poetas como Eliseo Diego, Eugenio Montejo y Jorge Teillier, ${ }^{23}$ permite también un

23 En Crónica del forastero (1968), Teillier intercala fragmentos de prosa referidos a otros tiempos, para poder ir y venir entre el pasado y el presente, volviendo a los orígenes del pueblo a finales del siglo XIX, a la ebullición ideológica de los años treinta, y al desgaste de la tierra y la extinción de las especies en el presente. 
desarrollo en el contexto urbano, sobre todo cuando la expansión de las ciudades ha supuesto la absorción - y frecuentemente la erradicaciónde pequeñas comunidades antes autónomas. Así, en El silencio de la luna, José Emilio Pacheco se empeña en desenterrar, dentro del espacio homogéneo de la Ciudad de México, las huellas de lugares que han sido sumergidos u olvidados por la urbanización: en "Entre paréntesis», el hablante cumple con la voluntad de un amigo muerto al esparcir sus cenizas «en lo que fue / el bosque de su recuerdo", aunque ahora los árboles no sean más que «puntos suspensivos, decoración / entre las casas desiguales» (1996: 139). Asimismo, "La Barranca del Muerto» empieza con un epígrafe que explica que en el siglo XIX pasaba por la barranca del título (ahora una avenida de la Ciudad de México) un arroyo nacido en las montañas. El hablante busca un lugar que ya no existe, una casa ya destruida que existía entre otras «casas de un solo piso o dos cuando mucho, / no grandes torres de altivez y de vidrio / o muros de concreto y soberbia insultante» - es decir, entre casas habitables, partes de una comunidad, que se encontraban, además, «muy cerca / de la Barranca del Muerto, / cuando era de verdad una barranca / con un hilo de agua / más turbio e inconfiable que mi empañado recuerdo" (145). La relativa pequeñez de las casas sugiere mayor intimidad, la posibilidad de una vida comunitaria acompañada al menos por el remanente natural del arroyo. «Cómo volver a ese lugar que ya no está?», se pregunta el hablante; pero aunque la vuelta real sea imposible, y aunque el lugar no se encuentre, el acto de buscarlo y de nombrarlo habla en sí de la falta y de la necesidad de un espacio particular donde poder vivir y convivir, y lo restituye al menos verbalmente, estableciéndose el poema como un pequeño desafío frente a la grandiosa y alienante impersonalidad del espacio urbano. El recuerdo «empañado» del hablante: ¿aludirá a las lágrimas que empañan sus ojos mientras recuerda, traumatizado por la pérdida?, ¿o bien se refiere a la memoria que se difumina, al último frágil vestigio de un pasado que cae irremediablemente en el olvido? Como en las palabras de Rilke citadas arriba, nombrar lo desaparecido permite conservarlo, quizá de la única manera posible: un recuerdo borroso, el trazo de unos nombres sobre el papel.

También Ernesto Cardenal efectúa esta especie de arqueología poética, indagando los procesos históricos subyacentes. Homenaje a los indios americanos (1970) va y viene entre el pasado y el presente de diversos pueblos indígenas, pero al comienzo de Oráculo sobre Managua (1973) el acercamiento 
a una zona periférica de la capital nicaragüense resulta particularmente interesante, contraponiendo o - mejor dicho, quizá- yuxtaponiendo un presente degradado a los restos de las culturas que antes poblaban la zona y que han sido conservados en capas geológicas al pie de los volcanes:

Detrás de la fábrica de Hilados y Tejidos (si ha quedado la fábrica tras el terremoto) y junto al cauce de desagüe, cerca del lago, entre basuras, bacinillas rotas, están o estaban las huellas, impresas en estrato volcánico.

Tal vez sin tejido textil, y ni siquiera cerámica, ocuparon esta área de Managua junto con el bisonte.

Vivían de la caza y la pesca y la recolección de alimentos.

Tiscapa, Asososca, Nejapa

las lagunas actuales eran un solo volcán humeante

y una vez cayó ceniza como una nieve negra

y quedaron las huellas en la corriente de lodo volcánico

que iba hacia el lago y bajo la ceniza se solidificaba:

huellas de gente en una misma dirección — hacia el lago-

huellas huyendo del volcán

unas hundidas más (indica que algunos llevaban cargas)

no corriendo (los pasos son cortos y regulares)

y hay huellas de venado cola-blanco nutria lagartijas

y un pájaro llamado guan (Penelope purpurascens)

y huellas de un bisonte... Sobre ellas cayó la lluvia negra. (1973: 7-8)

Descifrar las huellas, tener conciencia del pasado, es estar despierto a las posibilidades futuras de un lugar, y a la vez a todo lo que ha servido para configurar su presente. Las explotaciones e injusticias de hoy no existen en una burbuja; no estamos solos en la historia, sino entrelazados fatalmente con los que nos han precedido en un lugar y una cultura. Las distintas capas geológicas muestran el desarrollo de una región sujeta a los caprichos de la naturaleza, pero que ha sido capaz de crear el esplendor de la cultura maya y de conservar, entre la pómez de la última capa, restos de cerámica: «Monos / jaguares rojos con fondo blanco, incensarios. Y encima / trozos de Coca Colas y llantas Goodyear y bacinillas» (9).

Desde este panorama histórico, leído a través de las rocas, la descripción del suburbio de Acahualinca emerge contextualizada como parte de un larguísimo proceso de evolución histórica:

Allí empieza Acahualinca, las casas de cartón y latas donde desembocan las cloacas ... . 


\author{
Calles oliendo a cárcel \\ ese olor característico de las cárceles, a \\ mierda y orines rancios \\ casas de bolsas de cemento latas de gasolina ripios trapos viejos \\ Allí acaban las cloacas. \\ En la costa del lago los niños juegan haciendo hoyitos \\ con un palito a quién saca más moscas de su hoyito \\ En el agua algodones, papel de inodoro, algún condón. \\ Cerca el rastro. Sobre sus desperdicios zopilotes. (9-10)
}

Las calles huelen a espacios cerrados e inmundos, a cárceles. Aquí también suena el canto de las moscas, y también espera un pájaro negro: el zopilote. La miseria escandaliza porque la modernidad está omnipresente en este suburbio periférico, en la basura procedente del centro y en las cloacas que desembocan en la laguna envenenada de Acahualinca, tan poéticamente atroz en su color "verde-tierno", donde mujeres viejas se agachan para recoger tripas entre los desechos y lavarlas junto al desagüe y venderlas luego en el Mercado Central, así reciclando y repartiendo su insalubridad por toda la población de Managua.

Introduce el hablante, entre paréntesis, un irónico inciso: «(la luna riela sobre la mierda)». El verso de Espronceda y el mundo de belleza que evoca chirrían en este nuevo contexto degradado, aunque a la vez apunten hacia la terrible pero innegable belleza de lo contaminante en nuestros días: el verde-tierno del agua, los meandros arcoirisantes del petróleo en los charcos, el porfiado rojo de las latas de Coca Cola. Una imagen tópica de la naturaleza nicaragüense - «sobre techos de cartón y ripios un lago de tarjeta postal»— escandaliza por su contraste con la pobreza, así como cuando la poesía nicaragüense, encarnada en un Darío preciosista y su poema "Allá lejos» — penúltimo texto de Cantos de vida y esperanza; el primero de la madurez del poeta en que habla de Nicaragua-, se yuxtapone a palabras de los habitantes de Acahualinca:

\footnotetext{
Allá lejos, después de estos chiqueros, en el malecón

Darío con su camisón de mármol contra otro azul de postal

(también poluto)

"con la fuerza de la diarrea

se le brota el botón del culito»

«Toda la noche es un solo juy juy

si la voltean de costado el ruidaje de las tripitas

haga de cuenta y caso que vacían una tinaja». (11-12)
} 
Las contradicciones están a la vista, y la crítica de Cardenal echa raíces en las capas geológicas e históricas que antes desveló. Las rocas preservan el recuerdo de los que huían (en vano) de los periódicos desastres naturales; pero el desastre actual de Acahualinca, de este barrio afincado en la mierda y la basura, es un desastre humano, la creación consentida de un sistema injusto. El poema señala con ironía a los gobiernos que se desdoblan en gestos simbólicos, cada vez que los periódicos desastres naturales salen en primera página, mientras que los habitantes de Acahualinca son los «damnificados de un sismo permanente»: «no vendrán aviones / trayendo alimentos enlatados a esta gente / medicamentos, casas de campaña, agua potable». Los antepasados dejaron sus huellas en la roca: huellas que mostraron el lento desarrollo cultural que terminaría en la civilización maya; aquí, en cambio, hay un retroceso al infierno para los pobladores de Acahualinca. Sus huellas en el barro contaminado son crueles parodias de las que se dejaron siglos atrás:

Lentamente la corriente en dirección al lago

la corriente de mierda de Managua

y en ella huellas de pies desnudos

como los de aquellos que por allí fueron huyendo

a $10 \mathrm{mts}$. de profundidad como si fuera ahora en lodo fresco. (12)

En 1984 Cardenal publica Vuelos de victoria, un libro teñido por la euforia de la victoria sandinista de 1979, pero también por una curiosa fusión del discurso revolucionario con el ecologista. El poema «Nueva ecología», con entusiasmado voluntarismo, relaciona directamente la degradación ecológica de Nicaragua con Somoza, y constata y predice la recuperación de una armonía no sólo social sino también ecológica gracias a la llegada del nuevo régimen. Las culpas se enumeran con el nombramiento explícito de lugares dañados y especies desaparecidas por la codicia e insensibilidad de los seguidores del dictador:

Los somocistas también destruían los lagos, ríos, y montañas.

Desviaban el curso de los ríos para sus fincas.

El Ochomango se había secado el verano pasado.

El Sinecapa secado por el despale de los latifundistas.

El Río Grande de Matagalpa, secado, durante la guerra,

allá por los llanos de Sébaco.

Dos represas pusieron al Ochomogo,

y los desechos químicos capitalistas

caían en el Ochomogo y los pescados andaban como borrachos. 
El río de Boaco con aguas negras.

La laguna de Moyuá se había secado. Un coronel somocista robó las tierras de los campesinos, y construyó una represa, la laguna de Moyuá que por siglos estuvo bella en ese sitio.

(pero ya volverán los pescaditos).

Despalaron y represaron.

Pocos garrobos al sol, pocos cusucos.

La tortuga verde del Caribe la vendía Somoza.

En camiones exportaban los huevos de paslama y las iguanas.

Acabándose la tortuga caguama.

El pez-sierra del Gran Lago acabándolo José Somoza. (1984: 31-32)

Despalaron, represaron y contaminaron los ríos. El símbolo de esta situación a nivel nacional es, para Cardenal, el río Chiquito de la ciudad de León. Chiquito de nombre, casi humanizado en su frágil diminutivo, se convertirá en el poema (parafraseando a Alberto Caiero) en un río más grande que cualquier Amazonas, Paraná u Orinoco:

¡Y pobre el Río Chiquito! Su desgracia,

la de todo el país. Reflejado en sus aguas el somocismo.

El Río Chiquito de León, alimentado de manantiales de cloacas, desechos de fábricas de jabón y curtiembres, agua blanca de fábricas de jabón, roja la de las curtiembres; plásticos en el lecho, bacinillas, hierros sarrosos. Eso nos dejó el somocismo. (32)

Pero el daño ha sido superado. Añade el hablante, entre paréntesis, el verso: «(Hay que verlo otra vez bonito y claro cantando hacia el mar)». El poema, aunque en estos versos centrales hable de los destrozos del somocismo, se inició con la idea de la recuperación: «a poco del triunfo» ya se ven más coyotes y cuajipales por San Ubaldo, más conejos y culumucos en la carretera, y se ha triplicado la población de pájaros, notablemente la de los piches. Volverá a esta nota optimista en la última estrofa, así enmarcando y desactivando estructuralmente los daños mencionados. El hablante da una declaración de propósitos ecologistas («Vamos a descontaminar el lago de Managua») y una profecía —el tiempo, me temo, la habrá ridiculizado - acerca del éxito de estos propósitos («Recuperaremos los bosques, ríos, lagunas»). Personificados de nuevo, los pez-sierra y tiburones de agua dulce vuelven a respirar, aliviados después de la persecución somocista, y los cusucos «andan muy contentos con este gobierno». El poema termina con una última muestra, ahora totalizadora y llena de eufórica 
ingenuidad, de la fusión de las dos revoluciones. La distancia entre el ser humano y su entorno se borra. Todos somos parte de un mismo mundo. Es inútil intentar desgajar lo «humano» de lo «natural»:

La liberación no sólo la ansiaban los humanos.

Toda la ecología gemía. La revolución

es también de lagos, ríos, árboles, animales. (32)

\section{¿Conclusión?}

La alienación moderna nace de la pérdida del oikos: «la casa y la morada importan a los seres humanos porque sabemos lo que es la alienación y el estar sin domicilio. Otras especies moran perpetuamente, están siempre en casa en su ecosistema, su territorio» (Bate, 73). Si la recuperación de un sentido de arraigo significa el esfuerzo por volver a habitar y ser parte de ecosistema(s) más o menos sostenible(s), los beneficios podrían ser dobles: desde una perspectiva exclusivamente humana, la recuperación del arraigo eliminaría la experiencia moderna de la alienación; y en términos ecológicos, esta recuperada conciencia del lugar implicaría una nueva comprensión del entorno natural y de nuestra imbricación inevitable en él, y por tanto (es de esperar), un nuevo respeto hacia la vida y un cambio de actitud en nuestras prácticas más ecocidas. "El arte», decía Bate, "es el lugar de exilio donde lamentamos nuestra casa perdida sobre la tierra» (73). Si es cierto que el artista siente este exilio, esta alienación, de una manera particularmente aguda; más específicamente, si es cierto — como quería Pound- que los poetas son las «antenas de la raza» (digamos, mejor, de la cultura), no sería descabellado pensar que los lugares en la poesía nos están hablando de algo superior a la poesía y que nos atañe directamente en nuestras vidas. Abrámonos a los lugares; echemos raíces, por todas partes raíces, raíces que nos reconecten con la tierra, y con los pueblos, y también con las ciudades donde las fuerzas cíclicas siguen palpitando si sabemos abrir los ojos, y los oídos, y sentirlas y rescatarlas. En las páginas que siguen, hablaré de cinco de los poetas hispanoamericanos que con más empeño han luchado por volver a habitar, cada uno a su manera, poética y vitalmente la tierra. 



\section{CAPÍTULO 3. \\ DEL PÁJARO SIMBÓLICO AL PÁJARO REAL: \\ EL DESCUBRIMIENTO DEL (NUEVO) \\ MUNDO Y EL ADVENIMIENTO \\ DE LA ECOLOGÍA EN LA POESÍA \\ DE NERUDA}

La poesía moderna se construyó, desde sus comienzos, sobre el conflicto entre ciudad y campo. Crecían explosivamente los grandes centros urbanos y mientras tanto el campo, poco a poco, fue perdiendo protagonismo en el quehacer económico de las naciones y en su imaginario cultural. Algunos escritores, como los románticos ingleses, espantados por la modernización ideológica e industrial, se refugiaron en el espacio regenerador de la Naturaleza y descubrieron, lejos de la gran ciudad, la plenitud del ser. Otros, como Baudelaire, fijaron la pauta de lo moderno en la novedad del espacio urbano: espacio tematizado pero a la vez condicionador de gran parte de las innovaciones formales y de la visión general emergente en los nuevos poetas; espacio deslumbrante precisamente por su novedad, es decir, por su diferencia tan radical respecto a las formas de vida anteriores, en las que la agricultura había funcionado como motor principal de la sociedad.

Para los poetas urbanos que fueron urdiendo los varios ismos de la literatura moderna, la naturaleza ofrecía todavía un repertorio de imágenes fundamentales. Pero la vida urbana fue alejándolos de la vivencia de la naturaleza y el repertorio se convirtió, para muchos autores, en una colección de 
imágenes recogidas más del legado cultural que de la experiencia directa. La realidad del campo se fue esfumando del imaginario poético; de hecho, toda la realidad observada fue escamoteada en las tendencias más desrealizadoras de la poesía moderna. (No tenían, evidentemente, nuestra suerte de hoy, en que la naturaleza se nos ofrece en diarios documentales, como un espectáculo capaz de competir con los culebrones. Claro, como diría Fredric Jameson, en nuestro mundo postmoderno - mundo de la modernización completa - la tensión entre ciudad y campo se ha disuelto: vivimos en un espacio social homogeneizado en que la Naturaleza ha desaparecido (Jameson, 366). Es decir: el campo existe en función de la ciudad, sólo como espacio de ocio, escape de fin de semana o destino de vacaciones).

Creo, de todos modos, que la imaginación poética oscila siempre entre dos polos: por un lado, el mundo de lo ya leído, el museo imaginario de la experiencia cultural, que se reelabora al antojo del autor en su obra; y por otro, la experiencia — lo visto, sentido, gustado y oído - recogida y reelaborada por el autor, sin transformarse necesariamente en el realismo plano tan de moda hoy en día. Que las piezas del puzzle poético sean retazos de realidad: no imágenes muertas, metáforas ya demasiado manoseadas. Que el símbolo conserve su dualidad básica: la realidad palpada y, a la vez, la inquietante sugerencia de otras realidades.

El péndulo, como se ve, viene y va entre los polos, pero tiende —en su radicalidad moderna - hacia los extremos. Sólo hay que pensar en las imágenes naturales que dominaron en el modernismo y en tantos vanguardistas hispanoamericanos. Dentro de los "paisajes culturales» de Darío y su séquito, engalanados con cisnes y búhos y pavos reales, la enajenación frente a la Naturaleza fue enorme. En busca de lo otro, lo exótico y lo «bello», los poetas cerraron ojos, oídos y todos los sentidos. Huidobro, por su parte, despreció la animalia mitológica del modernismo: «Ignoro si otros poetas, al igual que yo, tienen horror a los términos mitológicos, y si también rehúyen los versos con Minervas y Ledas» (Huidobro, 686). Pero su naturaleza resultó igualmente «literaria». «Su fauna y su flora propias» (653), la realidad que buscaba supuestamente independiente de la «madre Natura", fue hecha, en realidad, a base de simples reelaboraciones de la tradición poética. Basta con volver a mirar sus pájaros: símbolos sin una pizca de existencia «real». Colocados en un mundo de artefactos modernos (lo nuevo) o mutilados en guerras de alta tecnología, siguen siendo los mis- 
mos pájaros literarios, en los mismos papeles simbólicos de siempre. Lo "poético», como un naipe, se baraja, corta y vuelve a repartir.

Para hablar de Neruda, para comprender las raíces y la evolución pasmosa de su poesía (hasta, digamos, 1954), de obra maestra en obra maestra, vale la pena detenerse aún más en Darío y Huidobro. A finales de Cantos de vida y esperanza, un libro en el que el cuestionamiento de la experiencia modernista se va haciendo progresivamente más angustioso, justo antes de la primera herida mortal de sus formas («Lo fatal»), la realidad palpitante de la vida — un retazo de naturaleza apresado por la memoria — irrumpe intempestivamente en la poesía dariana: «Buey que vi en mi niñez echando vaho un día / bajo el nicaragüense sol de encendidos oros / ... / Pesado buey, tú evocas la dulce madrugada / que llamaba a la ordeña de la vaca lechera» (Darío, 304). Enrique Lihn, en una durísima relectura hecha para el centenario del nacimiento de Darío en 1967, rescató la sustancia real de este poema, “Allá lejos”, y del "pesado buey” que [Darío] vió en su niñez en Nicaragua mucho más enterado de sí mismo y del mundo que los centauros —artefactos parlantes de la Bella Época» (Lihn, 64). Éste es, sin embargo - comprensiblemente, tal vez-, el Darío que Huidobro no toleraba. Lo dijo Gerardo Diego, al hablar de la admiración de su amigo por el gran fundador modernista: "Cierto - el "nicaragüense sol de encendidos oros" venía con frecuencia a sus labios como ejemplo del error en poética, de la "albarda sobre albarda", contrario a la perfecta economía creativa de su técnica» (Costa, 21). Había, por supuesto, mil ejemplos más notorios de adjetivación mortífera (de nuevo: el adjetivo, cuando no da vida, mata) en Darío, pero se entiende muy bien por qué fue éste el que volvía a los labios del chileno: él, como Darío, era un gran barajador de poéticas ya elaboradas, de símbolos machacados más allá de toda sugerencia, y hasta sus últimos años la realidad — sobre todo, horror de los horrores, la realidad americana — le seguiría siendo tabú.

Entre la tradición poética y la realidad: la naturaleza en Veinte poemas y Residencia en la tierra

La primera poesía de Neruda muestra este mismo repertorio de imágenes desgastadas. Abundan los pájaros genéricos, despojados de toda realidad extrapoética, reducidos a sus cualidades históricamente simbólicas 
—y, por tanto, "poéticas»: previsibles en su significación- como la libertad, el canto, el paso del tiempo y la belleza. En Veinte poemas de amor y una canción desesperada (1924), surge algún atisbo huidobriano que brilla con ingeniosidad creacionista: «Una gaviota de plata se descuelga del ocaso» (1999: 193). Más interesantes son, me parece, las imágenes surreales, esquirlas de realidad pesadillesca que transmiten urgencias nuevas en Neruda: "Los pájaros nocturnos picotean las primeras estrellas» (184). Pero también se nota, en algunos de los Veinte poemas, que el poeta va más allá de la simple redisposición de los símbolos prestigiosos. Las imágenes del pájaro de repente se concretan: «Para que tú me oigas / mis palabras / se adelgazan a veces / como las huellas de las gaviotas en las playas» (181); «He aquí la soledad de donde estás ausente. / Llueve. El viento del mar caza errantes gaviotas» (185). Son imágenes (y excepciones) que convencen visualmente como fragmentos de lo real observado, chispas de vida cargadas de sugerencia simbólica.

Las palomas y las golondrinas que pueblan las páginas de Residencia en la tierra fueron estudiadas con minuciosidad por el que sigue siendo, quizá, el gran crítico de Neruda, Amado Alonso, quien hizo hincapié en toda la observación anterior que debió de haber existido (según él) detrás de las imágenes: «Supongamos en el poeta una reiterada contemplación de las palomas, una repetida meditación poética sobre ellas, y sobre su forma, vuelo, arrullo, tacto, calor interior, movimientos del cuello y de la cabeza, pasos, plumaje, la vida encerrada en aquellas líneas estrictas, y, además, ciertas sugerencias venusinas tradicionales en la poesía" (Alonso, 221). Es mucho suponer. Yo postularía más bien una reiterada contemplación y repetida meditación poética sobre palomas verbales, palomas-símbolos de la gran tradición. La paloma real y contemplada apenas se asoma en las imágenes nerudianas; importan muchísimo más las sugerencias «venusinas» y, en general, toda la simbología poética y bíblica, eminentemente positiva, que rodea a este pájaro (por muy a-poético que nos resulte hoy: cuánto se echa en falta, en español, la diferenciación inglesa entre el pigeon urbano y la campestre y simbólica dove). Alonso insiste en que Neruda supera las equiparaciones programáticas de la tradición: «no hay un sistema de equivalencias racionales de tipo alegórico»; el poeta tiene "su nomenclatura simbólica peculiar» (220). El propio Neruda, por su parte, asediado por las preguntas del crítico, accedió en algún momento a descifrar o diseccionar su imagen, y comentó que «la paloma me parece la expresión más acabada 
de la vida, por su perfección formal» (228). En efecto, la simbología de la paloma se reduce más o menos a esto: el aura de perfección perceptible en cada una de sus apariciones en Residencia en la tierra. El logro estético de la imagen tiene menos que ver con su variedad que con la forma dinámica de relacionarse con su entorno en cada poema.

Las sugerencias venusinas se dejan ver en dos imágenes embellecedoras: «la paloma redonda / hace sus nidos blancos frecuentemente en ti» (1999: 270); "Oh niña entre las rosas, oh presión de palomas» (319). Más común, sin embargo - y seguramente más eficaz-, es el efecto discordante que Neruda provoca con imágenes expresionistas que hieren la "perfección formal» de la paloma, sumergiéndola en una realidad degradada y de pesadilla: "La paloma está llena de papeles caídos, / su pecho está manchado por gomas y semanas / por secantes más blancos que un cadáver / y tintas asustadas de su color siniestro» (309); hay una "paloma muerta, con un número» (320), y hay "water-closets blancos despertando / con ojos de madera, como palomas tuertas» (300). Otras imágenes, como la de «la paloma de sangre que está solitaria en mi frente» (292) y de «la paloma amarillenta que duerme en el olvido» (343), reflejan el desgaste que la realidad hostil le va imponiendo al hablante, como ese «agua de los muertos [que] me golpea / como palomas ciegas y mojadas» (337). En todos estos ejemplos (cada uno estremecedor), la realidad urbana que empieza a filtrarse en la poesía nerudiana se ilumina (y se oscurece) en el roce con el símbolo de la paloma, que ya está allí como un gran enigma al comienzo del libro, en "Galope muerto»: "Ahora bien, de qué está hecho ese surgir de palomas / que hay entre la noche y el tiempo, como una barranca húmeda?» (258). De lo que no está hecho, desde luego, es de palomas reales; ${ }^{24}$ sí, en cambio, de esperanzas y deseos y aspiración a la belleza, a la perfección.

24 Compárese la realidad palpable de la paloma en el soneto de Darío ya mencionado, «Allá lejos». Después de referirse al buey, el hablante rescata a la paloma que también vio en su infancia, "paloma de los bosques sonoros, / del viento, de las hachas, de pájaros y toros / salvajes»; la paloma y el buey "sois la vida mía», dice, y en el último terceto ancla la trascendencia del poema en este símbolo real, observado y recordado: «y tú, paloma arrulladora y montañera, / significas en mi primavera pasada / todo lo que hay en la divina Primavera» (1952: 305). 
La imagen de la golondrina tiene una función análoga. Este otro pájaro de prestigio poético llega cargado de connotaciones tradicionales asociadas con la vitalidad y la belleza de la primavera y, en su vertiente más negativa, con el implacable paso del tiempo. Surge, de nuevo, la duda: ¿la imagen se ha lexicalizado, es decir, visualmente ha muerto? ¿Seguimos viendo las golondrinas reales? ${ }^{25}$ Cuando habla, en "Tango del viudo", de «la golondrina que durmiendo y volando vive en tus ojos», o cuando se lamenta de «tantas golondrinas muertas» (337), el pájaro parece combinar los atributos de vitalidad y belleza, ambos amenazados en un mundo deshumanizado. Asimismo, cuando en "Oda a Federico García Lorca» habla de las "golondrinas verdes [que] hacen nido en tu pelo" (332), la irrealidad daliana - ¿o es, acaso, más cercana al nonsense cómico de Edward Lear? ${ }^{26}$ - vuelve a connotar una vitalidad (¿acentuada por el adjetivo?, ¡o se refiere, más bien, a un verde inquietante, putrefacto?) asociada ahora con la creatividad de la imaginación poética de Lorca.

En otra imagen, la golondrina funciona en un contexto erótico: "siento arder tu regazo y transitar tus besos / haciendo golondrinas frescas en mi sueño» (259). Amado Alonso vuelve a insistir en la base observada de la imagen:

El vuelo veloz y quebrado de este pájaro veraniego, que rasa la tierra o la tersa superficie de los ríos tocándola a veces con el intermitente leve tacto de la punta de sus alas, y las líneas estilizadas de su negro plumaje, que le hacen asemejarse a una flecha de fresca sombra yendo y viniendo por el aire bajo y ardoroso del verano, entran como elementos dominantes en una imagen que representa el delicioso escalofrío de los besos. (Alonso, 232-233)

Puede ser. Es evidente, en todo caso, que Alonso sí ha visto una golondrina y se ha esforzado por representar su realidad. Pero Neruda, y nosotros -lectores de Residencia en la tierra-, ¿realmente visualizamos el

25 A propósito: ¿qué ocurre, exactamente, con las «oscuras golondrinas» de Bécquer? ¿Su oscuridad es un truco simbólico para cargarlas de ominosidad? ¿Es la realidad escamoteada, contemplada parcialmente — olvidando el pecho blanco, olvidando el rojo collar? ¿O Bécquer, ornitólogo deficiente — los pájaros particulares brillan por su ausencia en sus versos (compáreselo, por ejemplo, con los románticos ingleses)—, confundió las golondrinas con vencejos, éstos sí siempre oscuros, chillones, crepusculares y ominosos?

26 Uno de los limericks más conocidos de Lear dice: «There was an old man with a beard / Who said: "It is just as I feared — / Two owls and a hen / Four larks and a wren / Have all laid their eggs in my beard"”. 
pájaro golondrina en estos versos, o se nos viene a la mente sólo la imagen desrealizada de la tradición poética?

Una última imagen, procedente del penúltimo texto del libro, sirve tal vez para aclarar estos mecanismos nerudianos:

He aquí violetas, golondrinas, todo cuanto nos gusta y aparece en las dulces tarjetas de larga cola por donde se pasean el tiempo y la dulzura. (344)

Las violetas y las golondrinas -imágenes tradicionales (y dulces) de la belleza, que indudablemente han decorado innumerables tarjetas- son paradigmas de lo que el hablante, desde una distancia claramente crítica, afirma que «nos gusta». El buen gusto y la belleza consagrada consuelan al lector, ofrecen una catarsis fácil, permitiéndole evadirse momentáneamente de la áspera realidad. Se podría comparar unos versos de Veinte poemas: "Historias que contarte a la orilla del crepúsculo, / muñeca triste y dulce, para que no estuvieras triste. / Un cisne, un árbol, algo lejano y alegre» (188). El cisne y el árbol ayudan a superar a la tristeza; Darío, en su prólogo a Prosas profanas, había anunciado su célebre repudio de «la vida y el tiempo en que me tocó nacer» y pobló las páginas del libro con cisnes — nunca vistos realmente - como emblemas de mundos lejanos y esplendorosos. Neruda nunca perdió este gusto por las imágenes tradicionalmente placenteras. Su cisne es un remanente modernista; no el que conoció en su infancia y que décadas después, en sus memorias, rescataría a la luz; ${ }^{27}$ el mismo, eso sí, que sirve — paradójicamente- como remate al conocidísimo manifiesto «Sobre una poesía sin pureza» (1935), la gran consagración de una poesía que se sitúa firmemente en la realidad y que se construye

27 «En el lago Budi perseguían a los cisnes con ferocidad. Se acercaban a ellos sigilosamente en los botes y luego rápido, rápido remaban... Los cisnes, como los albatros, emprenden difícilmente el vuelo, deben correr patinando sobre el agua. Levantan con dificultad sus grandes alas. Los alcanzaban y a garrotazos terminaban con ellos» (1988: 30). Sobre esta caza escribió Augusto Winter, el primer mentor poético de Neruda, «La fuga de los cisnes», que algunos han llamado el primer poema ecológico de Chile: «Reina en el lago de los misterios tristeza suma: / los bellos cisnes de cuello negro de terciopelo, / y de plumaje de seda blanca como la espuma, / se han ido lejos porque del hombre tienen recelo / [...] / El lago amaban donde vivían como señores / los nobles cisnes de regias alas; pero al sentir / cómo implacables los perseguían los cazadores, / buscaron tristes donde ignorados ir a vivir» (Molina y Araya, 321-322). 
fragmentariamente a partir de lo observado. Empieza el texto diciendo que "es muy conveniente, en ciertas horas del día o de la noche, observar profundamente los objetos en descanso" y ver en los objetos todas las huellas del ser humano. Termina, en cambio, con una defensa de la imaginería estética tradicional: "Y no olvidemos nunca la melancolía, el gastado sentimentalismo, perfectos frutos impuros de maravillosa calidad olvidada, dejados atrás por el frenético libresco: la luz de la luna, el cisne en el anochecer, "corazón mío" son sin duda lo poético elemental e imprescindible. Quien huye del mal gusto cae en el hielo» (2001: 381-382, la cursiva es mía). Aquí, el cisne poético sigue ofreciendo su consuelo supuestamente intemporal (gracias a su pureza, por mucho que Neruda hable de estos "perfectos frutos impuros»), como también lo han ofrecido las palomas y las golondrinas, chispas ideales de belleza, vitalidad y pureza en un mundo sometido a una lenta e implacable desintegración. ${ }^{28}$

Creo que se ve aquí el sentido básico de los pájaros de las Residencias. En esta época Neruda se va acercando a la materialidad del mundo que lo rodea. De hecho, la corriente realista de la "otra vanguardia» de inspiración anglosajona, que Pacheco (1979) encuentra en poetas centroamericanos y mexicanos como Salomón de la Selva, Salvador Novo y José Coronel Urtecho, tuvo quizá a su gran protagonista en Neruda: ${ }^{29}$ éste sabe

28 Más tarde, claro, cuando la realidad — que se incorpora fragmentariamente en las Residencias - se plasma en una visión unitaria fundada en la política, Neruda rechazará a los cisnes por sus asociaciones aristocráticas. En "Canto a Stalingrado», reflejan el escapismo traidor de Inglaterra en su política de No Intervention durante la guerra civil española: «España desangraba su inmenso árbol de sangre / cuando Londres peinaba, como nos cuenta Pedro / Garfias, su césped y sus lagos de cisnes» (1999: 394); y en el «Nuevo canto de amor a Stalingrado", el poeta puro que desprecia el realismo y la politización de la nueva poesía de Neruda, es comparado con un "cisne encuadernado", atrapado en las tradiciones de lo que el propio Neruda, breves años antes, había designado como «lo poético elemental e imprescindible»: "Yo sé que el viejo joven transitorio / de pluma, como un cisne encuadernado, / desencuaderna su dolor notorio / por mi grito de amor a Stalingrado» (396).

29 En una carta que escribió desde el Lejano Oriente en 1930, Neruda señaló las lecturas cuya resonancia se percibe en poemas residenciarios como "Caballero solo», "Ritual de mis piernas» y "Tango del viudo»: "Leo casi solamente en inglés, toda clase de cosas, especialmente los nuevos ingleses (hace 3 días ha muerto el más grande entre ellos, D.H. Lawrence), que tienen esto de curioso, que no se preocupan de ser ingleses "nuevos" (a excepción de Joyce) sino de relatar directamente, con cierta virilidad y descuido exteriores que es bastante agradable e inesperado para hombres como yo cuya sola noción literaria ha sido modificar la forma, problema cutáneo que me parece sin sentido" (Aguirre, 78; la cursiva es, por supuesto, mía). 
(después, por motivos políticos, fingirá no saberlo) que en un mundo fragmentado la realidad y, por extensión, el realismo son necesariamente surreales. Dentro de estos primeros tanteos realistas-surrealistas de Neruda, la imagen pura de los pájaros sirve como contrapunto al mundo moderno; ofrece una estructura "poética» en torno a la cual pueden articularse (y además, ser aceptadas como poesía) las impurezas de la vida urbana; y significa la esperanza —o la memoria - de una vida mejor, que sobrevive a duras penas, ella también contaminada por la degradación imperante.

\section{La armonía de la Tierra americana y sus hijos}

«La lámpara en la tierra», primera sección del Canto general, presenta una génesis cósmica del continente americano, una mitificación —en el poema inaugural, "Amor América (1400)»— del amor y de la armonía como ejes de la vida en la América precolombina. En los seis poemas de esta sección, la actitud de Neruda hacia la naturaleza ha cambiado radicalmente. El poeta se ha puesto a estudiar la realidad americana - la realidad que observa, y la realidad observada que encuentra en libros sobre la naturaleza- y se olvida de los tópicos de la tradición poética. Como en la «Silva a la agricultura de la zona tórrida" de Andrés Bello (pero con infinitamente más poesía), se da nombre aquí a una multitud de especies autóctonas de las Américas: árboles como el jacarandá, la araucaria, el ceibo y el ombú; reptiles y mamíferos como la iguana, el guanaco, el caimán y la anaconda; pájaros como el tucán, el colibrí, el quetzal y el cóndor. Cada especie muestra la grandiosidad, el vibrante colorido y la enorme diversidad de la naturaleza americana; cada una se enciende poéticamente con la deslumbrante imaginería nerudiana: «la araucaria de lanzas erizadas / era la magnitud contra la nieve» (1999: 419-420); «el guanaco fino como el oxígeno / en las anchas alturas pardas / iba calzando botas de oro»; "como el círculo de la tierra, / está la gigante anaconda / cubierta de barros rituales / devoradora y religiosa» (420-421); "volaba encima del mundo / el cóndor, rey asesino, / fraile solitario del cielo, / talismán negro de la nieve, / huracán de la cetrería» (422).

Todas estas especies son parte de una tierra fuertemente feminizada. La naturaleza y la mujer se fundieron en la poesía nerudiana desde sus comienzos. Si los Veinte poemas comienzan con imágenes naturales de una mujer 
erotizada y fértil («Cuerpo de mujer, blancas colinas, muslos blancos, / te pareces al mundo en tu actitud de entrega»), Canto general empieza con una visión de la tierra americana como un ser femenino y maternal: «amada de los ríos» y "madre de los metales», sus ríos son «ríos arteriales». Carolyn Merchant ha mostrado, en The Death of Nature, cómo la imagen predominante para la naturaleza, antes del Renacimiento, fue la de la madre nodriza: sus ríos venas, su rocío sudor, e incluso sus terremotos flatulencia (Merchant, 24-25). Neruda se re-apropia de la mirada premoderna o primitiva en múltiples referencias a la corporalidad de la tierra (Centroamérica es la "dulce cintura de América», [1999: 600]), y sobre todo a sus aspectos maternales: América es el «nuevo útero del mundo» (456); Arauco es «un útero frío» (486); una mina salitrera en Chile, «un útero infernal» (610).

De la misma manera, los indígenas precolombinos son retratados, desde el primer poema, como hijos de la tierra: «El hombre tierra fue, vasija, párpado / del barro trémulo, forma de la arcilla» (417). Esta identificación del indígena con la naturaleza se prolonga en el personaje de Caupolicán, «árbol duro de la patria» con «ojos implacables de la tierra» (487); y la educación de Lautaro consiste fundamentalmente en su integración en el mundo natural: «Educó la cabeza en las espinas. / Ejecutó las pruebas del guanaco. / Vivió en las madrigueras de la nieve. / Acechó la comida de las águilas. / Arañó los secretos del peñasco» (490). Pero no sólo los indígenas, sino también los libertadores y los demás luchadores por la libertad americana son parte de la naturaleza, hijos de la Madre Tierra: «Aquí viene el árbol, el árbol / de la tormenta, el árbol del pueblo. / De la tierra suben sus héroes / como las hojas por la savia» (478). De ahí la descripción del libertador San Martín: "Cuesta diferenciar entre los nudos / de ceibo, entre raíces, / entre senderos señalar tu rostro, / entre los pájaros distinguir tu mirada» (508); y Sandino, por su parte, «era un árbol que se enroscaba / o una tortuga que dormía / o un río que se deslizaba. / Pero árbol, tortuga, corriente / fueron la muerte vengadora, / fueron sistemas de la selva, / mortales síntomas de araña» (543). El propio poeta, que también se perfila como protagonista y héroe de su obra, ${ }^{30}$ hace hincapié en el contacto privilegiado con la tierra que él mismo poseyó desde la primera infancia:

30 Según Juan Villegas: «Como el héroe mitológico descrito por Campbell el personaje nerudiano ha logrado descubrir y poseer el elixir mágico y ha vuelto a su pueblo, como nuevo Prometeo, con el fuego anunciador de la redención» (1976: 84). 
«Lo primero que vi fueron árboles, barrancas / decoradas con flores de salvaje hermosura» (807). El papel central del hablante - ya en la cosmogonía inicial afirma que "yo estoy aquí para contar la historia», y se describe como «incásico del légamo» (417-418)— proviene justamente de esta relación intrínseca e intemporal con las profundidades de la tierra y de la historia americanas. El telurismo le permite saltar por encima de los límites temporales y unirse fraternalmente - mejor dicho, quizá, paternalmente- con los vencidos de la historia. Por eso, interrumpe su poema sobre Hernán Cortés para dirigirse a los tlaxcaltecas: "Hermano aterrado, no tomes / como amigo al buitre rosado: / desde el musgo te hablo, desde / las raíces de nuestro reino» (451).

La celebración de la América precolombina en esta primera sección del Canto general tiene, sin embargo, sus ambigüedades. Juan Villegas ha destacado la presencia de animales malignos en el poema "Algunas bestias»: los caimanes y los hocicos "saliendo del légamo" serían parte de "la noche original con su simbolismo de caos, terror e infortunio, las «tinieblas del universo", y el pantano sería "la zona del mal en la dualidad telúrica del bien y el mal» (Villegas, 199). Sin embargo, el propio hablante también pertenece a ese mundo primigenio del légamo («incásico del légamo»), y las connotaciones parecerían, al menos en esta imagen autorreferencial, ser positivas. En sus libros anteriores, Tentativa del hombre infinito (1925) y luego Residencia en la tierra, los «animales del sueño» - murciélagos, peces, caracoles e insectos: criaturas reptantes y legamosas, muchas de ellas surgidas del pantano- - intensificaron la angustia con su carga pesadillesca; ahora, en Canto general, los animales culturalmente más desprestigiados conforman un "bestiario» de insultos para los conquistadores y tiranos de Hispanoamérica: éstos son tigres, halcones y serpientes, cuervos, hurones, reptiles y arañas, chacales y cerdos, buitres, hienas, roedores y lobos, víboras, gusanos y moscas. Pero las analogías funcionan sólo en parte: en el mundo de la naturaleza, la noción del bien y del mal carece de sentido, y Neruda sigue (a veces) considerando la naturaleza (la precolombina, por lo menos) como un todo armonioso. Lo había dicho Quirón, en el «Coloquio de los centauros» dariano: «Ni es la torcaz benigna, ni es el cuervo protervo: / son formas del Enigma la paloma y el cuervo» (Darío, 205). Lo que veía el centauro con el panteísmo más bien teórico y literario de Darío, lo reafirma Neruda con el suyo, ya visceralmente sentido. Su primera representación del hombre americano es clave: 
El hombre tierra fue, vasija, párpado del barro trémulo, forma de la arcilla, fue cántaro caribe, piedra chibcha, copa imperial o sílice araucana.

Tierno y sangriento fue, pero en la empuñadura de su arma de cristal humedecido, las iniciales de la tierra estaban escritas. (1999: 417)

El hombre indígena es parte de la tierra, y su mezcla de amor y violencia («tierno y sangriento fue»), aparentemente paradójica, es un índice de su naturalidad y su participación en los ciclos del ecosistema que habitaba, pero que estaba a punto de perder:

Nadie pudo

recordarlas [las iniciales de la tierra] después: el viento

las olvidó, el idioma del agua

fue enterrado, las claves se perdieron

o se inundaron de silencio o sangre. $(417)^{31}$

Esta misma naturalidad se deja ver en «El corazón de Pedro de Valdivia», que celebra sin reticencias un acto de canibalismo ritual después de la muerte del conquistador de Chile, mediante la voz de un yo curioso - ¿es el propio protagonista-cronista quien habla: un «Pablo Neruda» capaz, como en otros textos del libro, de ir y venir en el tiempo?-:

Qué hermosa fue la sangre del verdugo

que repartimos como una granada, mientras ardía viva todavía.

Luego, en el pecho entramos una lanza y el corazón alado como un ave entregamos al árbol araucano.

Subió un rumor de sangre hasta su copa.

Entonces, de la tierra

hecha de nuestros cuerpos, nació el canto de la guerra, del sol, de las cosechas, hacia la magnitud de los volcanes.

31 ¿Nadie pudo recordarlas después? La poesía mapuche de Elicura Chihuailaf y Leonel Lienlaf muestra que ni las iniciales de la tierra ni el idioma del agua se perdieron del todo. Más bien, tuvieron que esconderse o callarse para sobrevivir. 
Entonces repartimos el corazón sangrante.

Yo hundí los dientes en aquella corola

cumpliendo el rito de la tierra. (494-495)

El rito no se condena porque es parte $-\mathrm{o}$ lo percibimos como parte- de la vida natural, "tierna y sangrienta», de los indígenas. Sin embargo, Neruda no presenta el mundo precolombino como un modelo. Su concepto del tiempo es más progresista que cíclico, aunque procure mostrar el progreso como un movimiento esencialmente ligado a los procesos evolutivos de la naturaleza: por eso, después de hablar de los sacrificios humanos de los mayas ("y escrutabais en los cenotes, / arrojándoles novias de oro, / la permanencia de los gérmenes»), se refiere inmediatamente a los conocimientos en Chichén Itzá, donde «el pensamiento amenazaba / la sangre de los pedestales, / desmontaba el cielo en la sombra, / conducía la medicina, / escribía sobre las piedras» (430). El pensamiento (así lo desveló, también, el árbol bíblico del conocimiento) permite ver la existencia del bien y del mal, y a la vez superarla; por eso, sugiere el poema, la etapa de los sacrificios humanos estaba a punto de terminar cuando llegaron los españoles. Porque aunque la violencia sea natural, el hombre como especie pensadora, al reconocer el sufrimiento como un mal, descubre - o puede descubrir, en el más alto grado de la civilización — la posibilidad de vivir en sociedad pacíficamente sin tener que enajenarse de la tierra.

\section{Imperialismo ecológico en Canto general}

Los primeros versos de Canto general aluden a la conquista española como exterminadora del "Amor América» precolombino: "Antes de la peluca y la casaca / fueron los ríos, ríos arteriales». La dicotomía es impactante: los conquistadores se presentan metonímicamente — son la peluca y la casaca-, con los atributos de su civilización (frente, se diría, a la «barbarie» indígena), pero éstos son a la vez signos de su alienación, elementos enmascaradores de una naturaleza perdida. Una dicotomía clásica —en la línea de Las Casas, por ejemplo— enfrentaría los apéndices de los europeos con la desnudez o la escasísima vestimenta de los indígenas, pero frente a la humanidad o la inhumanidad Neruda contrapone pri- 
mero los ríos arteriales, ríos que corren por el cuerpo de América, y en seguida las cordilleras, la humedad, la espesura, el trueno y las "pampas planetarias». Es decir, antes de la llegada del hombre europeo, estaba la naturaleza cósmica como un gran organismo, en el cual los indígenas no eran protagonistas centrales sino una simple parte integral e inseparable del ecosistema. En este sentido, más que un inicial enfrentamiento de la civilización y la barbarie, hay un choque de cosmovisiones radicalmente opuestas: el antropocentrismo anti-natural, por un lado; y por otro, un "geocentrismo" en el que el ser humano no se encuentra, ni se considera, ni se comporta como el señor y amo de su mundo. La integración de los indígenas en su entorno significó que su derrota también supondría, inevitablemente, una derrota de la tierra.

En las últimas décadas, se ha empezado a releer la conquista de América desde perspectivas ecológicas que ya estaban presentes, me parece, en la poesía nerudiana de Canto general. Alfred Crosby, por ejemplo, escribe sobre el «imperialismo ecológico» y la «expansión biológica de Europa», examinando los cambios en la naturaleza que acarreó la llegada de los europeos:

Norteamérica, la Sudamérica meridional, Australia y Nueva Zelanda están muy lejos de Europa pero gozan de climas similares al suyo, y la flor y fauna europeas, incluyendo los seres humanos, pueden sobrevivir en estas regiones si la competencia no es demasiado dura. En general, la competencia ha sido bastante blanda. En la pampa, los caballos y bovinos ibéricos hicieron retroceder al guanaco y al ñandú; en Norteamérica, las lenguas indoeuropeas han arrollado a los algonquinas, muscogeas (o kreek) y otras lenguas amerindias; en las antípodas, el diente de león y el gato doméstico del Viejo Mundo han ganado terreno frente a la «hierba de los canguros»y los kiwis. ¿Por qué? Tal vez los europeos hayan triunfado debido a su superioridad en armamento, en organización y en fanatismo, pero ¿̨por qué diantres nunca se pone el sol en el Imperio del diente de león? Tal vez el éxito del imperialismo europeo haya tenido un componente biológico, un factor ecológico. (Crosby, 18-19)

Elinor Melville (1994) ha hablado de este factor ecológico en términos de la plaga de ovejas y de otros animales que arrasó con los ecosistemas precolombinos de México, pero la verdad es que desde muy temprano, y no sólo entre las culturas indígenas, existía la conciencia de que la Conquista significó una lucha para vencer no sólo al indígena sino al ecosistema que lo sostenía. Lo había dicho en los años cuarenta el novelista chileno Mariano Latorre: «la historia del Chile austral, su pasado, su presente y su por- 
venir, no es otra cosa que la conquista de la selva y del indio pertinaz que aún vive en sus reducciones» (Latorre, 5). Es una visión que corresponde estrechamente a la de Neruda, en que el indio y la selva constituyen una misma entidad asolada por el imperialismo europeo. Escribe Latorre:

El arcabuz y la espada, en la primera época, el sable y el fusil en la pacificación de la Araucanía y en estos últimos tiempos, el hacha y la sierra, han conquistado la selva y han civilizado al indio araucano. Caían los árboles y morían los indios. El sendero de conquista lo marcaban los troncos derribados y los quilantares destruidos. $(7-8)^{32}$

Ya en las primeras crónicas, sobre todo en las que ilustran lo que Beatriz Pastor ha llamado el «discurso del fracaso» (las últimas cartas de Colón y Cortés, la crónica de Cabeza de Vaca), se describe las maneras en que la naturaleza se tornaba hostil y tomaba venganza contra los invasores. En su lectura de los cantos XXXV y XXXVI de La Araucana, Pastor ve este discurso del fracaso en la emblemática conquista del sur de Chile que emprendió Alonso de Ercilla bajo las órdenes de Don García: «el episodio de la expedición austral se organiza como una representación condensada del desarrollo de todo un siglo de conquista americana» (1983: 540). Ahí está el discurso mitificador - las promesas de riqueza, la idea de lo que Don García llama "otro nuevo mundo», la apelación a la providencia, la vida paradisíaca de los indígenas, etc.- - pero también el fracaso y la desmitificación: los guías indígenas les mienten, las promesas de Don García no se cumplen, y terminan los europeos luchando menos por el enriquecimiento que por la supervivencia (542). Sobre todo, me interesa señalar que la naturaleza es aquí un antagonista infinitamente más poderoso que el hombre indígena en sus intentos de rechazar la invasión:

\author{
Nunca con tanto estorbo a los humanos \\ quiso impedir el paso la natura \\ y que así de los cielos soberanos, \\ los árboles midiesen el altura, \\ ni entre tantos peñascos y pantanos
}

32 El ritmo de destrucción de los bosques nativos no ha dejado de aumentar y llegó a su apogeo bajo el régimen pinochetista. No es casual el título de Quiroga Martínez (1994): El tigre sin selva: consecuencias ambientales de la transformación económica de Chile: 1974-1993. 
mezcló tanta maleza y espesura, como en este camino defendido, de zarzas, breñas y árboles tejido. (Ercilla, 925)

Asimismo, "el cielo en contra conjurado» asalta a los europeos con "espesas nubes lóbregas», granizo y tempestades; los soldados piden socorro «en las hondas malezas sepultados» o bien «en húmidos pantanos atascados»; ruedan por cuestas, pierden sus caballos, y al final deambulan hambrientos, "descalzos y desnudos, sólo armados, / en sangre, lodo y en sudor bañados» (925-926). De esta manera, la tierra combatiente humilla a los invasores, sometiéndolos a un castigo simbólico por su irrupción violenta en cada uno de los ecosistemas de América.

Neruda toma y desarrolla este discurso ecológico incipiente. Si la tierra americana - desde una perspectiva geocéntrica - es una madre para sus hijos indígenas, la conquista antropocéntrica y eurocéntrica (o lo que llaman las ecofeministas androcéntrica) se describe como la violación y tortura de un cuerpo femenino: «Cuba, mi amor, te amarraron al potro, / te cortaron la cara, / te apartaron las piernas de oro pálido, / te rompieron el sexo de granada, / te atravesaron con cuchillos, / te dividieron, te quemaron" (1999: 449). Más tarde, en imágenes violentamente sexuales, muestra Neruda la penetración de Valdivia y sus tropas en tierras mapuches:

$$
\begin{aligned}
& \text { Valdivia entró la lanza goteante } \\
& \text { en las entrañas pedregosas } \\
& \text { de Arauco, hundió la mano } \\
& \text { en el latido, apretó los dedos } \\
& \text { sobre el corazón araucano. (470) }
\end{aligned}
$$

Si los conquistadores y sus herederos (los tiranos) se comparan repetidamente en Neruda con animales violentos, habría que destacar que la violencia de los animales - como la de los indígenas, tiernos y sangrientos - es una violencia natural, parte integral de los grandes ciclos armoniosos, mientras que la de los hombres «civilizados» es consciente, y por tanto mala, y por tanto siempre una violación. En contra de esta violación, la tierra americana (como la de Ercilla) se convierte en «tierra combatiente» para oponerse a los españoles: «Primero resistió la tierra. // La nieve araucana quemó como una hoguera de blancura / el paso de los invasores» (467). Su lucha, sin embargo, es vana: 


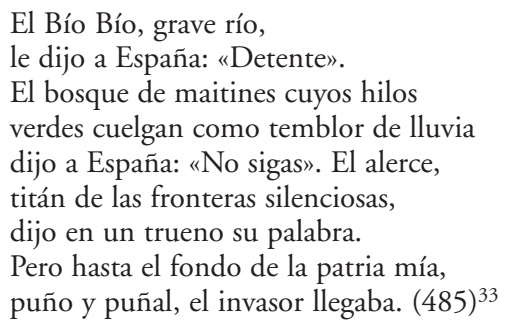

Ahora bien, no son sólo los soldados europeos los que luchan contra la naturaleza americana. La explotación de la tierra, y sobre todo la minería, también se retrata como una violación, como siempre lo fue de acuerdo con el telurismo premoderno:

Mientras la tierra fuera considerada viva y sensible, los actos destructivos en su contra podrían ser considerados una ruptura con el comportamiento ético humano. Para la mayoría de las culturas tradicionales, los minerales y los metales maduraban en el útero de la Tierra Madre, las minas eran comparadas con su vagina, y la metalurgia fue un adelantamiento humano del nacimiento del metal vivo en la matriz artificial del horno - un aborto prematuro del ciclo natural del crecimiento del metal. Los mineros ofrecían ritos propiciatorios a las deidades del suelo y del mundo subterráneo, celebraban sacrificios ceremoniales, observaban una estricta limpieza y abstinencia sexual, y ayunaban antes de violar la santidad de la tierra viva en el momento de excavar una mina. (Merchant, 4)

La época moderna empezó a ver el mundo con ojos muy distintos; el concepto de una Tierra Madre venerable se trocaba por la noción de un mecanismo inerte que los hombres podían explotar a su antojo. El cambio

33 Esta visión de la naturaleza en lucha contra el invasor no se limita a la época de la Conquista. En "Poema del momento extranjero en la selva", uno de los Poemas nicaragüenses de Pablo Antonio Cuadra, la flora y fauna de la selva rechaza a los quinientos marinos norteamericanos: "Pero hemos dicho que la selva es un viejo animal sobre la tumba de nuestros muertos / Hemos dicho que en el árbol de la noche el silencio empolla gavilanes furiosos. / Oigo voces. / Túngala, grita el sapo / Túngala clama el sapo-buey / Top, top, top, atestigua la iniquidad / el gran pájaro del sotocaballo. / Y vemos llegar al Pálido, / al Ojeroso-del-Alba con sus nubes de mosquitos zumbando y saliendo de las cuencas de su calavera / Y oímos sonar sus diminutos clarines / de pantano en pantano. / ¡Ah, vosotras!, neblinas húmedas / — grita_- ¡Ah!, nubes húmedas / nubes de inextinguible estridencia / Finas espadas de la fiebre / Anófeles / ínfimas águilas del pequeño escudo pisoteado / "e plúribus unum” / ¡Ah! / ... presenciamos / el retiro precipitado de 500 norteamericanos / pálidamente derrotados» (Cuadra, 150-151). 
de visión corresponde, claro, a los inicios del capitalismo y el consiguiente auge de la minería, y es retratado por Neruda como un sacrilegio. El poema "Minerales», de la primera sección de Canto general, contrapone la relación respetuosa de los indígenas con la tierra y las piedras preciosas («La turquesa / [...] / nacía apenas para las alhajas / del sol sacerdotal, dormía el cobre / en sus sulfúricas estratas») con la avaricia violadora de los españoles:

\author{
Madre de los metales, te quemaron, \\ te mordieron, te martirizaron, \\ te corroyeron, te pudrieron \\ más tarde, cuando los ídolos \\ ya no pudieron defenderte. (1999: 426)
}

La tierra se convierte, para los mineros explotados a lo largo de la historia americana, en un infierno, como el de la "criatura sin rostro» que se dirige al poeta desde «un útero infernal» en las salitreras chilenas (610). La convivencia del hombre americano dentro de la cíclica armonía de la Tierra Madre se había perdido definitivamente.

\title{
Crímenes ecológicos en el siglo XX
}

La perspectiva ecologista de Neruda, presente en esta visión de la Conquista y la Colonia, abarca también la defensa de los animales, como se percibe en la penúltima sección del libro, "El gran océano». Mientras «Leviathan» (799-801) ofrece una imprecación del sangriento exterminio de la ballena (precursora del Don't kill the whale actual), "Las aves maltratadas» habla de «la garuma de los mares», un pájaro que anida en los arenales de la pampa. El poema denuncia el ensañamiento del hombre y su violación de los ritmos naturales, ambos provocados por las demandas insaciables del capitalismo y de la gran urbe, que extienden sus tentáculos a todo lo largo del país:

\footnotetext{
Llegaron en el alba, con garrotes y con cestos, robaron el tesoro, apalearon las aves, derrotaron nido a nido la nave de las plumas, sopesaron los huevos y aplastaron aquellos que tenían criatura. Los levantaron a la luz y arrojaron contra la tierra del desierto, en medio del vuelo y del graznido y de la ola
} 


\begin{abstract}
del rencor, y las aves extendieron toda su furia en el aire invadido, y cubrieron el sol con sus banderas: pero la destrucción golpeó los nidos, enarboló el garrote y arrasada fue la ciudad del mar en el desierto.

Más tarde la ciudad, en la salmuera vespertina de nieblas y borrachos oyó pasar los cestos que vendían huevos de ave de mar, frutos salvajes de páramo en que nada sobrevive, sino la soledad sin estaciones, y la sal agredida y rencorosa. (799)
\end{abstract}

Estos poemas confirman la idea de María Magdalena Sola de que Neruda, «llevado por su fervor de naturalista y su peculiar "bucolismo", marcó la avanzada en lo que hoy se llama ecología y conservación del ambiente» (Sola, 133). Abundan las ambivalencias en esta postura: "Tomadas por sí solas, las denuncias de Neruda contra los estragos de la minería, la pesca y el comercio sobre la naturaleza podrán confundirse con el bucolismo", pero "Neruda no es tan simple; en esta misma obra, hay diversos ejemplos de alabanza al poder humano para producir riqueza, pero ha de ser en bien de todos, dentro del sistema socialista. La desplanificación, el egoísmo y el desmedido afán de lucro del capitalismo como sistema son para él las raíces de este mal» (131-132).

En el tercer poema de la sección «Que despierte el leñador», Neruda celebra la reconstrucción de la Unión Soviética después de la segunda guerra mundial en términos inconscientemente contradictorios, que dejan patentes los costos ecológicos del crecimiento del nuevo país comunista. Las palabras, como siempre, traicionan al ideólogo. Sólo así podemos comprender la ironía salvaje de los versos siguientes: «Y un canto de martillos alegra el bosque antiguo / como un nuevo fenómeno azul» (la cacofonía es canto; el bosque sufre alegremente la tala; todo conforma un mundo tan dudosamente ideal como las azules lejanías de Darío). Las imágenes también se rebelan: «los ingenieros hacen temblar el mapa / de las llanuras con sus números / y las cañerías se envuelven como largas serpientes / en las tierras del nuevo invierno vaporoso» (he aquí la burocratización de una naturaleza que tiembla, acaso atemorizada; las siniestras cañerías que reemplazan a las serpientes reales; y el «nuevo invierno vaporoso», una premonición 
del smog que hoy conocemos tanto). Y como último ejemplo de estas contradicciones, habría que fijarse en las extrañas yuxtaposiciones (fábricas y canciones), el contraste tal vez implícito entre las flores de la selva y las escuelas, y el papel de víctima del zorro, sacrificado en el proceso industrializador y tildado de «salvaje», quizás en un guiño a la antigua dicotomía de la barbarie y la civilización, como si Neruda pudiera realmente justificar la extinción de un animal en aras del progreso:

Desde aquí miro extensas zonas de hombre,
geografía de niños y mujeres, amor,
fábricas y canciones, escuelas
que brillan como alhelíes en la selva
donde habitó hasta ayer el zorro salvaje. (688-689)

Estas contradicciones textuales delatan un conflicto que el propio Neruda quizá no advirtiera aún a mediados del siglo: la lógica y los intereses de los sistemas industrializados y del ecologismo son intrínsecamente opuestos. El hombre natural, cuya infancia fueron «zapatos mojados, troncos rotos / caídos en la selva, devorados por lianas / y escarabajos, dulces días sobre la avena» (807), al hacerse comunista adoptó una postura política que el tiempo ha mostrado incompatible con el ecologismo; lo es, seguramente, en su esencia más profunda, es decir, su esencia más profundamente moderna y antropocéntrica. Sólo años después, en la poesía conscientemente ecologista de Fin de mundo (1968), pudo darse cuenta Neruda de que el maniqueísmo de sus ideas políticas resultaba ecológicamente insostenible. En todas partes del mundo moderno (y bajo todos los regímenes, capitalistas y comunistas) cocían habas. Quizá corresponda repetir los versos de este libro ya citados en el capítulo anterior:

Venecia desapareció

debajo de la gasolina,

Moscú creció de tal manera

que murieron los abedules

desde el Kremlin a los Urales

y Chicago llegó tan alto

que se desplomó de improviso

como un cubilete de dados.

Vi volar el último pajaro

cerca de Mendoza, en los Andes.

Y recordándolo derramo

lágrimas de penicilina. (2000: 454) 


\section{CAPÍTULO 4. \\ EL DESPERTAR AMERICANO DE GAIA: ECOLOGISMO, ECOFEMINISMO YTRADICIONALISMO EN GABRIELA MISTRAL}

\section{La Diosa redescubierta}

La recuperación de Gaia en la imaginería científica y popular de las últimas dos décadas forma parte de una búsqueda más amplia por una «Diosa» prepatriarcal, a quien habría que rescatar — se dice- como urgente antídoto al vacío espiritual de nuestros tiempos secularizados. Títulos como Lost Goddesses of Early Greece (1978) de Charlene Spretnak, The Goddess: Mythological Images of the Feminine (1981) de Christine Downing, When God was a Woman (1976) de Merlin Stone, The Goddesses in Everywoman de Jean Shinoda (1984), Eros and the Womanliness of God (1986) de Ingrid Shafer, The Reflowering of the Goddess (1990) de Gloria F. Orenstein y Goddess: Myths of the Female Divine (1994) de David Leeming y Jake Page son sintomáticos tanto del alcance de esta búsqueda de nuevas respuestas como de la moda a veces un tanto epidérmica que ha suscitado.

Según los entusiastas de la Diosa, ella inaugura «una nueva fase de espiritualidad» (Matthews, 23); surge de nuestros sueños individuales y colectivos y tiene «una vida propia que rompe con las normas establecidas por siglos de dominación masculina de Dios en nuestra organización social y en nuestras formas de pensar», de tal manera que nosotros, al examinar aquella 
vida, «tal vez podamos ayudar a restablecer el equilibrio dentro de nosotros y en nuestro mundo» (Leeming, 4). Así, la búsqueda de la Diosa corresponde no sólo a una nueva forma de combatir la tierra baldía y el caos de la vida (post)moderna, sino a una visión que culpabiliza a las estructuras sociales y religiosas del sistema patriarcal por el desequilibrio imperante. En este sentido, se vincula con ciertas corrientes del movimiento feminista:

Muchas mujeres han redescubierto la necesidad que tenemos de la diosa en una cultura que nos aparta de la mujer, de las mujeres y de nosotras mismas. Estar alimentada solamente de imágenes masculinas es estar gravemente desnutrida. Estamos hambrientas de imágenes que reconozcan lo sagrado en lo femenino y la complejidad, riqueza y poder nutritivo de la energía femenina. (Downing, 15)

En la década de los cincuenta, en Lo sagrado y lo profundo, Mircea Eliade dio protagonismo a la imagen primordial (y universal) de la Tierra Madre, cuya veneración en sociedades primitivas había supuesto una sacralización no sólo de la naturaleza, sino también de la mujer: «la fecundidad femenina tiene un modelo cósmico: el de la Terra Mater, la Genetrix universal» (1992: 124). Los restos de esta religión de la tierra seguían vivos, decía Eliade, en las sociedades modernas, salvo para una pequeña minoría, integrada sobre todo por "los hombres de ciencia» (130). No cabe duda de que el rumano subestimó la profundidad de las raíces que el cientificismo ha echado en la cultura popular. Como destaca Carolyn Merchant en The Death of Nature (1990), desde los comienzos de la modernidad la naturaleza mecanizada de Descartes desataba una desacralización feroz de la imagen maternal y nutricia de la tierra y a la vez descartaba con sorna la supuesta sabiduría telúrica de las mujeres (de ese desprecio, comenta Merchant, surgió la persecución de las «brujas»).

Las buscadoras (¿y los buscadores?) de la Diosa procuran volver a tiempos premodernos y muchas veces a épocas precristianas y hasta pregrecolatinas, en las que la naturaleza viva del animismo o del panteísmo conservaba su sabor distintivamente femenino. Como dice Downing, «el primer objeto de culto religioso fue la Gran Madre», una diosa que aseguraba la nutrición de los seres humanos y la continuidad de los grandes ciclos naturales (1999: 21), y en cuyo honor las relaciones sexuales y el parto fueron considerados como actos sagrados (27). Gaia, la Madre Tierra de los griegos, fue la primera diosa del panteón olímpico, antes de ser 
desplazada por Deméter, Temis y Perséfona y luego abandonada en el olvido. El trigésimo de los «himnos homéricos», escrito en el séptimo o sexto siglo antes de Cristo, está dedicado a ella — «Gaia, Madre de todos»—, y la celebra como nodriza del mundo y madre paradójica, hoy benévola y mañana inmisericorde:

Voy a cantar a Gaia, madre universal, de sólidos cimientos, la más augusta, que nutre en su suelo todo cuanto existe. Cuanto camina por la divina tierra o por el ponto, o cuanto vuela, se nutre de tu exuberancia.

Por ti se vuelven prolíficos y fructíferos, soberana de ti depende dar la vida o quitársela a los hombres mortales... (Bernabé, 299) ${ }^{34}$

Aunque este himno luego se desvíe hacia una concepción claramente patriarcal del mundo (los favoritos de Gaia son hombres que gobiernan en una ciudad de hermosas mujeres), se ven en él los vestigios de esa religiosidad anterior para la cual la Diosa fue rectora del mundo.

Rescatada de los tiempos prehoméricos, la figura de Gaia resume los atributos más apreciados por investigadoras actuales de la Diosa; sobre todo cuando se reconoce - es la opinión de muchas- que las diosas posteriores (Afrodita, Hera, Atenea y Cía.) están «demasiado contaminadas por las influencias patriarcales de la Grecia clásica como para que sean de suficiente ayuda a aquellas de nosotras que buscamos a las diosas como remedio para liberarnos de los estereotipos femeninos de inspiración patriarcal» (Downing, 32). La conclusión es previsible: las «mentiras que contó Homero" provocan, en las mujeres de hoy (feministas y ecofeministas), una "comprensible» decepción e indignación (34).

\section{La hipótesis de Lovelock}

Gaia, entonces, es el gran modelo occidental de la Diosa, la encarnación mítica de una necesidad sentida, quizá, por todas (¿por todos?), porque «ella es la respuesta a ese anhelo profundo por regresar al hogar que ninguna madre (ni amante como sustituto de la madre) puede satisfacer» (Downing, 168).

34 He reemplazado la palabra Tierra, en la traducción de Bernabé, por el nombre original en griego: Gaia. Su traducción resulta hoy redundante. 
O, en palabras de Claudio Guillén, Gaia «es una metáfora romántica que responde a nuestra necesidad de unidad» (Joseph, 57). Por eso, fue evidentemente un acierto el nombre que escogió el científico James Lovelock - siguiendo un consejo del novelista William Golding — para bautizar en 1979 a su innovadora y pronto célebre teoría como Gaia. ${ }^{35}$ La hipótesis de Gaia de Lovelock vuelve a considerar la Tierra como un gran organismo (o algo que funciona, al menos, como un organismo), afirmando que la vida es un fenómeno a escala planetaria y que el concepto de evolución de Darwin —en que «organismos mejor adaptados que otros tienen más probabilidad de dejar descendencia» - resulta insuficiente, puesto que la relación entre el entorno y los seres vivos no es unilateral sino recíproca: «es necesario añadir que el crecimiento de un organismo afecta a su medio ambiente físico y químico, por tanto la evolución de las especies y la evolución de las rocas están estrechamente ligadas como un proceso único e indivisible» (Lovelock, 1995: 78). Desde la perspectiva de Gaia, homo sapiens es una especie más entre otros tantos millones de organismos y, como todos ellos, está imbricado en complejísimas redes de interdependencia con la naturaleza viva y no viva.

Según Downing y Guillén, Gaia satisface una necesidad espiritual intrínseca en los seres humanos. En cuanto a Lovelock, parte de su experiencia personal (en los años sesenta trabajó en la NASA) para llegar a conclusiones parecidas: «Cuando la especie humana ha podido contemplar desde el espacio la refulgente belleza de su planeta lo ha hecho con un asombro teñido de veneración que es el resultado de la fusión emocional de conocimiento moderno y de creencias ancestrales» (1985: 7). ${ }^{36}$ Eliade dijo que los «hombres de ciencia» eran los que más habían perdido el sentido religioso de la Naturaleza; pero después de la visión del orbe azul, deslumbrantemente vivo entre los

35 La alternativa, por lo visto, fue un nombre algo menos atractivo: «Sistema Universal de Tendencia Biocibernética/ Homeostasis» (Joseph, 25).

36 Esta motivación de Lovelock puede sonar caprichosa. Pero Leonardo Boff, que sigue al inglés en sus referencias a Gaia, transcribe testimonios igualmente maravillados de diversos astronautas. Destaca la versión de Gene Cernan: «Yo fui el último hombre en pisar la luna en diciembre de 1972. Desde la superficie lunar miraba con temor reverencial hacia la Tierra sobre un trasfondo de azul muy oscuro. Lo que yo veía era demasiado hermoso para ser captado, demasiado lógico, lleno de finalidad, para ser el fruto de un mero accidente cósmico. La gente se sentía interiormente obligada a alabar a Dios. Dios tiene que existir por haber creado aquello que yo tenía el privilegio de contemplar. [...] Desde allá arriba no se distinguen las barreras del color de la piel, de la religión y de la política que allá abajo dividen al mundo" (Boff, 1996a: 250-251). 
demás planetas «muertos», los científicos — mejor dicho, ciertos hombres y mujeres de ciencia - han vuelto a acercarse a la mística y han recuperado la noción de una Tierra Madre. Lovelock procura hablar "en nombre de Gaia» para defenderla (1995: 13), pero advierte que ella, como la diosa del himno homérico, "no es una madre cariñosa y tolerante con las malas conductas, ni tampoco es una damisela frágil y delicada en peligro por las acciones humanas». Al contrario, la capacidad de autorregulación de Gaia y su «objetivo inconsciente» de preservarse como un planeta adaptado para la vida son tales que «si la humanidad sigue en el camino actual, será eliminada» con la misma falta de piedad que mostraría un misil nuclear balístico (228). Nuestra depredación ecológica, susceptible al castigo de la Diosa, tiene sus raíces, según Lovelock, en el antropocentrismo y el humanismo modernos que han establecido al ser humano como propietario del planeta; la hipótesis de Gaia, en cambio, afirma que «el estado estable de nuestro planeta incluye al hombre como parte de o socio en una entidad muy democrática» (1985: 170).

Para Darwin, la competitividad entre las especies era el eje básico de la evolución. Lovelock extiende esta idea de la evolución a las partes no vivas del planeta: los minerales, los océanos y el clima. Por otra parte, ve el proceso de la selección natural como algo que depende tanto de la cooperación como de la competencia entre las especies. Las investigaciones de la microbióloga estadounidense Lynn Margulis — la aliada más importante de Lovelock en la divulgación de sus teorías - han servido para legitimar científicamente algunas de las ideas aparentemente más peregrinas y utópicas del inglés:

La simbiosis — la asociación mutuamente provechosa de dos o más organismos de diferentes especies- es un patrón universal de conducta microbiana. A nivel del microcosmos, la cooperación simbiótica es al menos tan importante como la competición por «la supervivencia del más fuerte»; para competir — para entrar al juego en primer lugar- tienes que cooperar. Nosotros creemos ahora que la visión doctrinaria de una "Naturaleza con dientes y garras ensangrentados» es ingenua e incompleta. La simbiosis significa supervivencia. (Joseph, 31$)^{37}$

37 Peter Bowler lamenta la oposición extrema entre el darwinismo exacerbado de la gran mayoría de los científicos contemporáneos y la visión de Lovelock y sus seguidores: «Los ecologistas radicales estimulan activamente la idea de que la Tierra debe ser tratada como un sistema femenino, orgánico, que alimenta a toda la vida, incluida la nuestra. [...] Sin embargo, paradójicamente, la ciencia se ha comprometido cada vez más firmemente con un modelo de la naturaleza basado en la lucha individual, filosofía de que el diablo se lleva al que se queda rezagado, que poco apoyo ofrece para relaciones interespecies armoniosas y apoya abiertamente la competencia como mecanismo de progreso dentro de las especies» (1998: 401). 


\section{Ecofeminismo}

Estas ideas de Lovelock se acercan a la mirada holística de la llamada "ecología profunda» ${ }^{38}$ y de algunas líneas del ecofeminismo. En un texto clásico dentro de esta tendencia, la holandesa Maria Mies y la india Vandana Shiva consideran al ser humano como una especie capaz, en principio, de mantenerse dentro de la red de la vida, pero sólo "por medio de la cooperación, el cuidado mutuo y el amor» (Mies, 15). Ahora bien, el "sistema mundial patriarcal-capitalista», en su afán competitivo y dominador, ha violado egoístamente esta red en su explotación de la naturaleza y al mismo tiempo, a lo largo de la modernidad, ha suprimido y oprimido a la mujer. Opuesto a este doble abuso, el ecofeminismo surge también como un movimiento de autocrítica frente a las tendencias más masculinizadoras del feminismo, que han defendido el derecho y la capacidad de las mujeres de competir en iguales términos con los hombres en la sociedad capitalista:

En tanto que feministas empeñadas activamente en la liberación de las mujeres de la dominación masculina, no podíamos ignorar, no obstante, que los procesos de "modernización" y "desarrollo" y el "progreso" son los causantes de la degradación del mundo natural. Veíamos que los desastres y el deterioro ecológicos tenían mayores repercusiones para las mujeres que para los hombres y, también, que las mujeres eran en todas partes las primeras en protestar contra la destrucción del medio ambiente. Como activistas de los movimientos ecologistas, llegamos a ver claramente que la ciencia y la tecnología no eran neutras en relación con el género y, al igual que muchas otras mujeres, empezamos a comprender que existía una estrecha conexión entre la relación de dominio explotador entre el hombre y la naturaleza (modelada por la ciencia reduccionista moderna a partir del siglo XVI) y la relación de explotación y opresión entre hombres y mujeres que impera en la mayoría de las sociedades patriarcales, incluidas las sociedades industriales modernas. (9-10)

La liberación de las mujeres, desde la perspectiva de Mies y Shiva, está intrínsecamente relacionada con la lucha por defender el planeta. Parte de esta lucha consiste en recuperar la sabiduría transmitida de generación en generación por las mujeres en sociedades premodernas,

38 Véase, por ejemplo, Deep Ecology: Living as if Nature Mattered, de Bill Devall y George Sessions (1985). 
fruto de su relación con la naturaleza, y que ha sido — a lo largo de la modernidad - suprimida. Así, se podría librar a las mujeres y a la naturaleza de la destrucción del sistema patriarcal (30) y el Primer Mundo volvería a descubrir el carácter sagrado de la vida y de la Tierra. Aunque esta propuesta pueda parecer próxima a un "espiritualismo de lujo», explotable con fines comerciales en el nuevo mercado de productos esotéricos, corresponde en realidad a algo todavía considerado natural por las mujeres del llamado Tercer Mundo, que nunca han dejado de vivir en estrechísimo contacto con la tierra:

Ellas no necesitan matizar el término Madre Tierra poniéndolo entre comillas, porque para ellas la Tierra es un ser vivo que garantiza su propia supervivencia y la de sus semejantes. Respetan y celebran el carácter sagrado de la Tierra y se resisten a que sea transformada en materia prima muerta para la economía industrial y la producción de mercancías. (34). ${ }^{39}$

Ver el papel de la Tierra Madre en Gabriela Mistral permitirá una lectura matizada del atrevimiento universalizador de Mies y Shiva, pero antes conviene recordar que las palabras, como siempre, tienden trampas. Patrick Murphy, en el capítulo «Sex-Typing the Planet: Gaia Imagery and the Problem of Subverting Patriarchy» de su libro Literature, Nature, and Other: Ecofeminist Critiques, pregunta si la nueva personificación del planeta como Gaia realmente se opone, como pretende, a la ideología patriarcal de dominación de la tierra, o si más bien — gracias a sus implicaciones metafóricas - reinscribe inadvertidamente elementos de la misma ideología y del mismo sistema que aspira a subvertir (1995: 59). Según Murphy, la imagen de Gaia, aunque ésta sea una diosa procedente del matriarcado anterior, nos llega ya contaminada por la mitología patriarcal grecolatina (como en el himno homérico mencionado arriba). Por eso lamenta que, en vez de referirse al planeta Tierra con la neutralidad del término organismo, se haya vuelto a un nombre que reafirma la visión patriarcal de la mujer en sus papeles de madre, nodriza y protectora. Al combatir el antropocentrismo moderno, Lovelock ha caído en la trampa de los nombres e «inconscientemente refuerza el androcentrismo

39 Sobre el ecofeminismo en el mundo latinoamericano, véase la compilación de Margarita Velázquez (1996). 
al caracterizar el lado femenino de la dualidad como pasivo» (60). Esta puesta en duda de la imaginería de Gaia servirá para comprender las motivaciones profundas y también las consecuencias de su uso en la poesía de Gabriela Mistral, y tal vez para iluminar algunos riesgos del discurso ecofeminista.

\section{Conversaciones sobre la tierra: el telurismo de Gabriela Mistral}

En un artículo de 1931, "Conversando sobre la tierra», Gabriela Mistral enfrentó el problema de la «enajenación del suelo» en Hispanoamérica, su "pérdida lenta y sorda" en manos de inversores capitalistas extranjeros que hallaban en las tierras del Sur un negocio enormemente prometedor. Desde una lógica mercantilista masculina, «tienen perfecta razón los hombres de negocios nuestros al invitarlos, y ellos la tienen también al instalarse regaladamente» (1978: 94). Sin embargo, Mistral procura hablar en nombre de "esa masa a la que pertenezco en cuanto a persona sin tierra", pero que forma parte de un país que va dejando, poco a poco, de pertenecerle; lamenta la crisis cultural y económica que esta pérdida supone para los latinoamericanos, puesto que la tierra es — dice- el sostén fundamental tanto de la cultura como del bienestar material de un país (y un continente): «Las cosas visibles y las invisibles descansan sobre ella, desde la más pesada, como el metal vulgar que es el hierro, hasta la fina como la canción regional; la santa nutridora hace salir de ella lo mismo el clásico café que el pensamiento de Hostos» (95). Tan profunda es esta relación entre la tierra y los seres que la habitan, que existe una «alianza perdurable del alma, cuerpo y suelo», cuya pérdida conduce a la locura. Mistral declara haber visto este enloquecimiento en campesinos franceses cuyas tierras fueron replantadas con pinos y encinas, y afirma que lo mismo ocurriría en su región natal: «arrásenle al viñatero de mi valle de Elqui la viña que poda, que riega y vendimia, y se quedará como un demente sin saber qué hacer de sí por un largo tiempo"; y aunque luego aprenda por necesidad otro oficio, «el alma no se soldará con él, y se morirá como el peón de viña al que le robaron en la parra la vida» (96).

Anticipando los planteamientos del ecologismo profundo y del ecofeminismo, Mistral exalta el vínculo del ser humano con su lugar de origen, 
sacralizando la tierra como un ser femenino que es la «santa nutridora» de sus habitantes. La relación de la mujer con la tierra es infinitamente más íntima que la de los hombres: mientras éstos se alejan de ella, interesándose por la aventura física y por acciones, bonos y valores — «la aventura acostada en papeles numerados» (97) - , las mujeres prefieren quedarse con el predio, la granja y las cosechas seguras. Por eso, «el mundo habría sido puro nomadismo y fuego fatuo de aventura incansable si no le ponen al Adán la Eva al costado y en ella la responsabilidad de los hijos». Este papel maternal y hogareño influye en todo el desarrollo cultural de un lugar: «la mujer crea sobre la tierra pesada de la que está segura, las costumbres que traen también su plomo adentro» (98).

Para confirmar esta dicotomía esencialista — las diferencias biológicas de cada sexo, en vez de las diferencias culturales propias del género- entre el hombre nómada y la mujer casera, Mistral busca paralelos en los pueblos «primitivos» europeos y americanos. Cuando éstos «asignaban al hombre el fuego y el aire como elementos suyos y señalaban a la mujer la tierra como su lote, tenían razón redonda, y acertaban en pleno, y más acertaron dando a la costra cultivada nombres femeninos, como Ceres o Pomona o Diosa del Maíz» (97): son tres de las diosas predilectas de la poeta, primas hermanas de la Gea (Gaia) de su obra posterior.

\section{La Gea americana}

Ya en Desolación (1922) Mistral se refería a la tierra como un personaje vivo, asociado fundamentalmente con la maternidad: «No había visto antes la verdadera imagen de la Tierra. La Tierra tiene la actitud de una mujer con un hijo en los brazos (con sus criaturas de los anchos brazos). Voy conociendo el sentido maternal de las cosas. La montaña que me mira, también es madre, y por las tardes la neblina juega como un niño por sus hombros y sus rodillas» (2001: 133). La femineidad de la tierra no se limita aquí a las formas onduladas y fértiles de los valles, sino se extiende al áspero contorno rocoso (muchas veces, tradicionalmente, relacionado con la masculinidad) de la montaña: por eso, "dicen que el cordillerano / mamó leche de dos pechos, / el uno blando y florido, / el otro taimado y recio" (2001: 602-603); y son frecuentes en Mistral las referen- 
cias a la Cordillera como una madre - "iCordillera de los Andes, / Madre Yacente y Madre que anda!» (364)_, en cuyos "pechos de amargura» la joven poeta se crió (119). La vida — como en la Gaia de Lovelock— no se restringe a los seres vivos del planeta, sino que incluye a las piedras y a las rutas, ambas nombradas como madre en el Poema de Chile (1967) y ambas protagonistas en la intrincada red de la vida planetaria. ${ }^{40}$ Lo ha señalado Fidel Sepúlveda: "Para una ecología que se ciñe al estudio y la defensa de los seres vivos [es decir, no una ecología al estilo Lovelock], la piedra, el fuego de la entraña de la tierra, en rigor no tienen cabida. Pero en Gabriela Mistral, la entraña pétrea y su emergencia están vivas. No sólo eso, sino que como cordillera, se signa con el título de matriarca» (1995: 61).

En su recorrido del país, junto con un muchacho indígena y un pequeño ciervo, el yo-fantasma de Poema de Chile presenta una visión animista de la "Tierra Mama» (2001: 731), en que todos los seres vivos y no vivos hablan con ella y entre sí. No sólo la cordillera y la ruta son madres; también lo son las palmas (612-613) y las araucarias (665), mientras que los animales y las plantas más pequeñas son nombrados y tratados como hermanos. Todos los seres son miembros de una gran familia, como se podrá ver en el siguiente diálogo —entre el yo y el niño- de "A veces, mama, te digo»:

\author{
¿Con quién hablas, dime, cuando \\ yo me hago el que duerme... y oigo? \\ Será con los animales, \\ la hierba o el viento loco. \\ - Porque todos están vivos \\ y a lo vivo les respondo. \\ También contesto a lo mudo, \\ por ser mis parientes todos. (583)
}

Ahora bien, esta comunicación familiar con la naturaleza sólo es posible si se establece con ella una relación de armonía, y no de explotación, como señala el yo al hablar de su propia infancia:

40 El cobre sale de la tierra «hermoso / como nunca se lo vieron / las piedras que eran sus madres» (2001: 571); «Te traje por andurriales, / dejando a la bien querida, / la Madre y Señora Ruta, / madre tuya y madre mía» (575). 
Me tenía una familia

de árboles, otra de matas,

hablaba largo y tendido

con animales hallados.

Todavía hablo con ellos

cuando te vas escapado.

Pero ellos contestan sólo

cuando no les haces daño.

No los hostigó mi Santo

Francisco y les dijo hermanos. (584)

La alusión a San Francisco, santo patrono de los ecologistas, ${ }^{41}$ es una muestra del sincretismo espiritual y cultural de la poeta, que le permite acompañar al santo con reiteradas alusiones a diosas grecolatinas como Cibeles, Ceres, Deméter y sobre todo —en sus últimos años—a Gaia o, como Mistral la escribe, Gea; ${ }^{42}$ una Gea "personificada — si no divinizada- desde una concepción próxima al animismo de los pueblos andinos y no del todo ajena a ciertos aspectos del franciscanismo y de las doctrinas espiritualistas a las que Mistral fue siempre aficionada» (Daydi-Tolson, 198).

La primera mención de Gea en la poesía mistraliana (en 1954, en Lagar) supone una americanización radical del mito griego. En su «Alocución a la poesía», de más de un siglo antes, Andrés Bello había invitado a la "Divina Poesía» a trasladarse desde una Europa demasiado "culta», donde la naturaleza imprescindible para la escritura ya no existía, hacia tierras americanas todavía vírgenes:

41 «El espíritu revolucionario más grande de la historia de Occidente, San Francisco, propuso lo que consideraba una visión cristiana alternativa de la naturaleza y de la relación del hombre con ella: intentó sustituir la idea del señorío sin límites del hombre sobre la creación por la idea de la igualdad de todas las criaturas, entre ellas el hombre. Fracasó. Tanto nuestra ciencia actual como nuestra tecnología actual están tan teñidas por la arrogancia cristiana ortodoxa hacia la naturaleza que no se puede esperar de ellas una solución para nuestra crisis ecológica. Puesto que las raíces de nuestro problema son en tan gran medida religiosas, el remedio debe ser también religioso en su esencia, llámeselo así o no. Debemos volver a pensar y sentir nuestra naturaleza y nuestro destino. El sentimiento profundamente religioso, pero herético, de los franciscanos primitivos ante la autonomía espiritual de todas las partes de la naturaleza señala una dirección posible. Yo propongo a Francisco como santo patrono de los ecologistas» (Lynn White: 14).

42 Las alusiones a Gea se encuentran en Lagar $(2001$ : 442; 461; 551) y en los libros póstumos Poema de Chile (566, 610, 649, 705, 724, 731) y Lagar II (1991: 65-67, 89, 94). 


\author{
Divina Poesía \\ tú de la soledad habitadora, \\ a consultar tus cantos enseñada \\ con el silencio de la selva umbría, \\ tú a quien la verde gruta fue morada, \\ y el eco de los montes compañía; \\ tiempo es que dejes ya la culta Europa, \\ que tu nativa rustiquez desama, \\ y dirijas el vuelo adonde te abre \\ el mundo de Colón su grande escena. (1978: 21; cursiva mía)
}

A su manera, Mistral efectúa una apropiación paralela de lo europeo, pero esta vez no es el exceso cultural sino la barbarie de la guerra lo que la impulsa. En "Caída de Europa», un poema dedicado a Roger Caillois durante la Segunda Guerra Mundial, el yo mira hacia la tierra europea como a una vieja madre afligida: "acribillada / de fuegos y ahogada de humareda / arde la Vieja Madre que nos tuvo / dentro de su olivar y su viña» (2001: 442). Si la Europa de Andrés Bello había perdido sus grutas verdes y sus montes poéticos, la de Mistral ya no «tiene» a sus hijos americanos en su naturaleza de viñas y olivares; después de procrearlos y luego, desde lejos, tenerlos o controlarlos política, económica y culturalmente, la sombra protectora de Europa ha sido rasgada, acaso definitivamente, por la Guerra, y ya no se sabe si realmente sigue siendo madre para ellos:

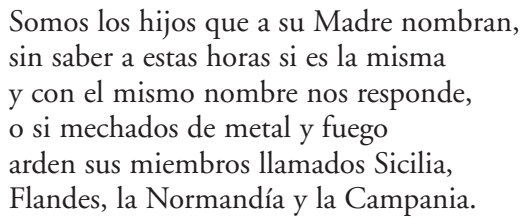

Pendiente de noticias de la Guerra que llegaban siempre tardías y confusas, el yo teme que la mutilación o desmembramiento termine en la muerte de la Vieja Madre. En este contexto surge la alusión a una Gea que también — como la poesía en Bello- ha tenido que trasladarse al otro lado del Atlántico. Mientras la Madre Europa «en aflicción espera, / mirando fija un cielo de azabache / que juega a rebanarle la esperanza / y grita "No eres" a la Vieja Noche»,

Solamente la Gea americana vive su noche con olor de trébol, 
tomillo y mejorana y escuchando el rumor de castores y de martas y la carrera azul de la chinchilla. (443)

En América hoy, decía Bello, como en Europa ayer, hay una naturaleza digna de ser poetizada: "También propicio allí respeta el cielo / la siempre verde rama / con que al valor coronas; / también allí la florecida vega, / el bosque enmarañado, el sesgo río, / colores mil a tus pinceles brindan». Del mismo modo, sólo en América hoy — dice Mistral— podrá la antigua Gea griega seguir existiendo en paz. Para ambos autores, la tierra americana y la cultura que surge de ella son el futuro, herederas y sucesoras de las tierras y culturas europeas que han entrado definitivamente en la decadencia.

En Poema de Chile, el yo se dirige a la «larga Gea chilena» (609), encarnando en ella los poderes maternales y a la vez la capacidad autorregulatoria que atribuye Lovelock a la Gaia de sus teorías:

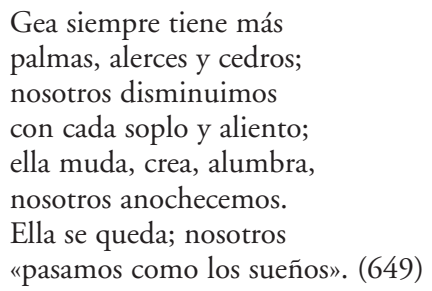

Vale la pena recordar que la vigencia de este contraste entre la fugacidad del ser humano y la renovación cíclica y sempiterna de la tierra se ha ido gastando con el paso de los años, sobre todo en el contexto de la deforestación galopante que existe hoy en Chile y en toda Latinoamérica. En términos de Lovelock, se podría decir que aunque Gaia sobrevivirá, el alerce, el cedro y el ser humano, manifestaciones diferentes de la vida (y frente a las cuales, se diría, Gaia permanece indiferente), están todos amenazados con la extinción.

En una nota que añadió en 1945 a su libro de canciones de cuna, Ternura (1924), Mistral defendía la complicidad femenina con Gea, comentando la extraña ausencia de la mujer en la historia oficial de la música — siendo ella mucho más propensa al canto que el hombre en la vida cotidiana-, y concluyendo que su invención musical había sido canalizada tradicionalmente hacia las canciones que componía y cantaba mientras mecía al niño sobre sus rodillas o en la cuna. Este acto de cantar, en medio de la naturale- 
za y sobre todo en noches llenas de ruidos y vida oculta, trasciende la relación entre madre e hijo y se carga de telurismo. La canción de cuna es «un coloquio diurno y nocturno de la madre con su alma, con su hijo, y con la Gea visible de día y audible de noche»; mientras canta la mujer, «no sólo oye respirar al chiquito; siente también a la tierra matriarca que hierve de prole» (1986: 106-107). Presos del canto, se quedan dormidos no sólo el niño, sino también esa tierra matriarca y al final ella misma: las identidades de madre, niño y naturaleza terminan así fundiéndose, impregnándose una de la otra.

\section{La maternidad omnipresente}

Que los hombres estén excluidos de esta complicidad con Gea, se percibe claramente en la visión negativa que adopta Mistral hacia la caza. En varios momentos de Poema de Chile, el yo reprende al niño indígena por su inclinación depredadora que es, según ella, típicamente masculina. ${ }^{43}$ Cuando el niño se queja porque ella estorba su persecución de los animales, la «Mama» establece una división tajante:

— ¡Cada bicho me lo asustas

y yo regreso sin nada!

- ¡Ay, tienes tiempo sobrado

para hacer la villanada!

Los hombres se sienten más

hombres cuando van de caza.

Yo, chiquito, soy mujer:

un absurdo que ama y ama,

algo que alaba y no mata,

tampoco hace cosas grandes

de ésas que llaman hazañas. (2001: 653)

43 Mistral ve la caza no como un acto de complicidad con el entorno (la visión, por ejemplo, de poetas como Gary Snyder y Ted Hughes), sino como una actividad esencialmente dañina para los ciclos naturales, algo incontrolable que desembocará en la explotación insostenible (como hoy se dice) y la extinción de las especies perseguidas: «¿Cómo es — pregunta_, chiquito, / que todavía hay hermana chinchilla? / Las hostigan y las cogen. / Quien las mira las codicia, / los peones, los chiquillos, / el zorro y la lobería" (2001: 577). No obstante, las quejas más vehementes del yo surgen cuando el niño pretende cazar a una castora con críos: «-Óyeme, indito, oye, Mío: / nunca mates lo que es madre / que amamanta bajo el cielo, / da su leche y acarrea / semillas y "comederos" (692). El gran tema, como siempre en Mistral, es la defensa de la maternidad. 
Por un lado, el hombre: un ser vanidoso que mata, por gusto o ambición, en el curso de sus hazañas; por otro, la mujer: un ser que ama, cuya relación pacífica con la tierra corresponde a la imagen de una Gea regida por la armonía. Esta dicotomía se presenta, para Mistral, en el comportamiento distinto de los dos progenitores con los niños. Las madres van enseñando al niño, en las canciones de cuna y en paseos por el campo, los procesos de la naturaleza: «En esas canciones tú me nombrabas las cosas de la tierra [...]. Tú ibas acercándome, madre, las cosas inocentes que podía coger sin herirme; una hierbabuena del huerto, una piedrecita de color; y yo palpaba en ellas la amistad de las criaturas» (1976: 11); los padres, en cambio, están «demasiado llenos de afanes para que puedan llevarnos de la mano por un camino o subirnos las cuestas», y andan «en la locura heroica de la vida» (12).

El protagonismo de Gea y de las otras manifestaciones de la Tierra Madre está vinculado en Mistral a la celebración de lo maternal que atraviesa, como obsesión, toda su obra, multiplicándose en diversas formas y permeando todo lo que toca. Hay textos en que la poeta celebra a su madre todavía viva (1976: 11); otros, posteriores, en que llora a la madre muerta (2001: 313); en varias ocasiones, lamenta su propia condición de «mujer estéril» (45) y al hijo que supuestamente nunca tuvo - «Un hijo, un hijo, un hijo! Yo quise un hijo tuyo / y mío, allá en los días del éxtasis ardiente»- (94); sueña con dar el pecho a un «hijo hermoso» (103); inventa un hablante-madre para las canciones de cuna de Ternura; dedica las ganancias de su libro Tala «a los niños españoles dispersados a los cuatro vientos" durante la Guerra Civil (426); imagina un encuentro póstumo con el amante muerto como si ella fuera madre y él su hijo: «Te acostaré en la tierra soleada con una / dulcedumbre de madre para el hijo dormido» (81); elogia el papel de madre sucedánea que desempeña la maestra rural (su propia profesión), que es "más madre que las madres» (125); y por último, habla —en el octavo mandamiento de su «Decálogo del artista»— del proceso de la escritura poética como si fuera un parto: «Darás tu obra como un hijo, poniendo en ella tu sangre de mil días» (153). ${ }^{44}$

44 Y en el poema "El suplicio», también de Desolación: «Tengo ha veinte años en la carne hundido / - y es caliente el puñal - / un verso enorme [...] // Como un hijo, con cuajo de mi sangre / se sustenta él, / y un hijo no bebió más sangre en seno / de una mujer» (2001: 48). 
Esta omnipresencia de lo maternal fue un factor determinante, sin duda, para el Premio Nobel que recibió Mistral en 1945, después de seis años de guerra en una Vieja Europa hambrienta de paz y vida familiar. No es extraño, por tanto, que en el prólogo a la traducción francesa de su obra, publicada el año siguiente, Paul Valéry haya destacado y celebrado esta particularidad de su obra: «Esta mujer canta a los niños como nadie lo había hecho antes de ella. Mientras tantos poetas han exaltado, celebrado, maldecido o invocado a la muerte, o edificado, ahondado, divinizado la pasión del amor, pocos hay que parezcan haber meditado en el hecho trascendente por excelencia, la producción del ser vivo por el ser vivo» (Oyarzún, 11).

\section{Ecofeminismo y tradicionalismo}

Pionera del ecofeminismo en su equiparación de mujer y tierra y en su rechazo de los comportamientos anti-ecológicos masculinos, Mistral define el abismo que separa a la mujer del hombre en términos estrictamente biológicos o esencialistas. Patricia Pinto Villarroel, en un estudio de Poema de Chile cuyas conclusiones valen para toda la obra de la poeta, advierte en ella «una fuerte dosis de acatamiento al rol tradicionalmente asignado a la mujer — madre dadora de vida y conservadora de ella - y de apropiación de roles tradicionales adscritos al varón - poseedor del saber, custodio celoso de éste, dueño del poder— (1989: 36). Es posible, pero habría que recordar que su saber no es el saber de los hombres, sino una sabiduría telúrica específicamente femenina. Por otro lado, ese tradicionalismo (tan comentado) resulta especialmente llamativo en la introducción a Lecturas para mujeres, el libro de textos escolares que Mistral preparó como encargo de la Secretaría de Educación de México en el año 1924. Allí cuestiona las nuevas libertades ganadas - mediante una larga y laboriosa luchapor la mujer occidental: «la participación, cada día más intensa, de las mujeres en las profesiones liberales y en las industriales, trae una ventaja: su independencia económica, un bien indiscutible; pero trae también cierto desasimiento del hogar, y, sobre todo, una pérdida lenta del sentido de la maternidad». En su defensa de este amenazado sentido de la maternidad, Mistral rema a contracorriente, encontrando «los mejores tipos de mi sexo» en las mujeres antiguas, más austeras y «más leales a los fines verdaderos de la vida». Porque al fin y al cabo - y en esta línea se va guiando 
en su selección de lecturas escolares—, «sea profesionista, obrera, campesina o simple dama, su única razón de ser sobre el mundo es la maternidad, la material y la espiritual juntas, o la última en las mujeres que no tenemos hijos» (1976: XV-XVI).

Aquí está el gran "problema» no sólo de la actitud de Mistral, sino de las consecuencias de una ideología ecofeminista basada en una vinculación visceral entre la mujer y la tierra. No es casual que ella haya resucitado a esa Gea, cuya reencarnación finisecular en Lovelock suscitó las reticencias de Patrick Murphy. La poesía de Mistral confirma esas dudas: Gea representa míticamente una ideología que refuerza y celebra las diferencias - que son, para la poeta, no culturales sino esenciales - entre el hombre racional y explotador y la mujer intuitiva y tierna. Mistral conserva los papeles impuestos por el patriarcado, pero invierte la valoración y la jerarquización habituales en la modernidad. Para el feminismo clásico, los papeles tradicionales relegaron a la mujer a su animalidad más instintiva, atándola irremediablemente a la tierra y perdiéndola si no lograra cumplir con su incontestable vocación maternal. La pregunta está abierta y se plantea, teóricamente, con los tópicos seculares de lo masculino y lo femenino: ¿debería la mujer irse masculinizando y acompañar al hombre (a codazos) en su carrera andro y antropocéntrica hacia la destrucción? ¿ O debería el hombre renunciar a esa carrera y feminizarse, asumiendo los papeles cooperadores de la mujer, para que juntos abandonen el capitalismo suicida y contribuyan a la formación de un nuevo mundo, sin duda ecológicamente más feliz? 



\section{CAPÍTULO 5. INDICIOS DEL FIN EN LA POESÍA MEXICANA. JOSÉ EMILIO PACHECO: ENTRE EL APOCALIPSIS Y LA CATÁSTROFE}

\section{Quinientos años de degradación ecológica}

Pocos países sufren los estragos del deterioro ecológico con tanta virulencia como México, y si los proyectos desarrollistas de la modernidad conducen en todas partes a un callejón sin salida, raras veces se ha contemplado el fin del camino con tanta nitidez como en los poetas José Emilio Pacheco (Ciudad de México, 1939) y Homero Aridjis (Michoacán, 1940), ambos residentes en la capital mexicana, probablemente la ciudad más contaminada del mundo. Junto con Nicanor Parra y Ernesto Cardenal, son dos de los grandes protagonistas de la nueva poesía ecologista en Hispanoamérica.

Cuando llegaron los españoles a la cuenca de México en 1519, se encontraron con lo que era, probablemente, el área urbana más grande y más habitada del planeta (Ezcurra, 34), rodeada por montañas verdes de pinos y encinas. Sobre los cinco lagos del valle los aztecas habían construido las ciudades de Tenochtitlán y Tlatelolco, y habían elaborado el sistema de las llamadas chinampas, islas de tierra artificialmente erguidas sobre los lagos y los canales, irrigadas por las aguas y fertilizadas por las plantas acuáticas. Estas chinampas lograron una gran productividad y die- 
ron de comer a los numerosos habitantes de la zona, haciendo la región casi autosuficiente, aunque el maíz, los frijoles y otros productos esenciales fueran importados desde las provincias como tributo de guerra.

La Conquista supuso un trastorno ecológico radical. La ciudad que se construyó sobre las ruinas de Tenochtitlán renegó del pasado lacustre: el agua, para los españoles, era un estorbo, así que taparon canales, quitaron las chinampas y elevaron sobre el suelo húmedo las calles requeridas por la nueva civilización ecuestre. Iniciaron, a la vez, la deforestación de la Nueva España: se necesitaba madera para la construcción de la nueva ciudad y para la minería (como combustible, para apuntalar los socavones, etc.), y también había que despejar tierras para la ganadería extensiva. Elinor Melville habla de "la plaga de ovejas» que trajo la conquista de México; pero fue, en realidad, una plaga de todo un bestiario de animales desconocidos: «la presencia de pollos, cerdos, burros, cabras, ovejas, vacas, caballos y mulos es el testimonio de una revolución ecológica desencadenada por la invasión europea» (Melville, XI). El alcance de esta revolución se revelaba en las primeras catástrofes ecológicas de la zona: los 25 millones de indígenas que habitaban el centro de México a la llegada de Cortés se redujeron a 2,6 millones después de las epidemias de 1545-1548, y sumaron sólo un millón a comienzos del siglo siguiente (Ortiz, 155). Por otro lado, la tala de bosques en los montes más cercanos y la sustitución de canales por calles obstruían el drenaje de la ciudad y provocaron en 1553 , 1580 y 1604 inundaciones tan grandes que el virreinato se veía obligado a emprender obras hidráulicas de gran alcance: en 1608, el Tajo de Nochistongo, un canal de drenaje de 15 kilómetros, abrió la cuenca de México a la adyacente cuenca de Tula. Así empezó una lucha con y contra el agua que se ha ido agudizando sin pausa hasta el presente.

El siglo XX vio una intensificación vertiginosa de los problemas ecológicos en México. Por un lado, la deforestación se propagó a lo largo del país; por otro, la capital se convirtió en «el paradigma del desastre urbano, el arquetipo de los crecientes problemas ambientales y sociales de las ciudades del tercer mundo» (Ezcurra, 1). La industrialización de los años cuarenta impulsó a una población empobrecida a abandonar las provincias para buscarse la vida y la riqueza en la capital. Las estadísticas sobrecogen: hubo 700.000 habitantes en la Ciudad de México en los tiempos de la Revolución; hoy hasta 20 millones viven y malviven en una megápolis des- 
mesurada, desbordante, hipercefálica. Siguen llegando, cada día, hasta 1.500 nuevos y esperanzados inmigrantes, pero llegan a una ciudad herida, quizá de muerte, por la explosión demográfica.

Crece la población y crece la contaminación. En 1940, circulaban 150.000 vehículos motorizados por las calles de la ciudad; hoy son más de cuatro millones. La presencia cotidiana del smog, acentuada por la inversión térmica en el invierno, multiplica las enfermedades respiratorias, sobre todo entre niños y ancianos, deja huellas corrosivas en los monumentos y las fachadas de los edificios, ${ }^{45} \mathrm{y}$ ha ocultado, tal vez para siempre, los antes imponentes volcanes de Popocatépetl e Iztac Cíhuatl. Los problemas del agua han llegado a un punto crítico: la deforestación de las laderas de la cuenca las ha incapacitado como captadoras y filtradoras del agua pluvial y como alimentadoras de los acuíferos; por otro lado, la desviación y entubamiento de los ríos y el inmenso sistema de abastecimiento y drenaje contribuyen a la desecación del valle. México D.F. se está quedando sin agua; además, disminuidos los acuíferos subterráneos, la ciudad se hundió hasta nueve metros en el siglo XX y los fundamentos de muchos edificios padecen una precariedad tal que están a la merced de cualquier terremoto. Por otra parte, el agua que llega bombeada a la capital, desde distancias de hasta cien kilómetros, extiende la desecación más allá de los límites de la zona metropolitana; mientras tanto ésta devuelve, con venenosa reciprocidad, sus aguas residuales a las provincias que la rodean (Romero Lankao, 236-241).

La deforestación y la erosión de los suelos afecta todo el país, acarreando las consecuencias locales y globales conocidas de sobra, pero la situación resulta particularmente exacerbada en la selva de Lacandón en Chiapas, donde la explotación humana y ecológicamente insostenible ha conducido al estado de sublevación permanente de las fuerzas zapatistas bajo el mando del subcomandante Marcos. Habría que destacar las múltiples especies de animales y plantas, amenazadas tanto por la tala de bosques como por la contaminación, que pierden su hábitat y corren

45 «Haciendo un recorrido por las calles del centro, como 5 de Mayo, Palma y Tacuba, se puede apreciar que las esculturas de ángeles no tienen espada, que les faltan pies y manos a los santos, y que hay pájaros ya sin alas adornando edificios. En la catedral el rostro de san Agustín, en la torre poniente, está desfigurado. Además, las tres esculturas de Manuel Tolsá «Fe, Esperanza y Caridad», situadas sobre el reloj, las balaustradas y todas las esculturas de la torre oriente ya no tienen cara» (Ortiz, 289). 
grave peligro de extinción. Como siempre, la posible desaparición de un animal funciona como un poderoso acicate para un público ecológicamente indiferente o ciego, pero la respuesta de los conservacionistas suele ser insuficiente, como si la amenaza a especies aisladas no fuera un síntoma de una enfermedad más amplia, la de todo el ecosistema, que incide también, de manera lógicamente preocupante, en los seres humanos. La defensa de la naturaleza y la preocupación por las condiciones de vida cada vez más degradantes de los seres humanos son las dos caras de una misma situación: el desarrollo escandalosamente insostenible y una mirada política a cortísimo plazo que ha echado a perder los indudables avances en otros aspectos de la vida. ${ }^{46}$

\title{
José Emilio Pacheco: fugacidad, sufrimiento y metapoesía
}

En un poema de Irás y no volverás (1973), José Emilio Pacheco - reflexionando, como siempre, sobre cómo, por qué y para quién escribepone en boca de Prometeo el siguiente consejo poético:

\author{
Y recuérdalo bien: hay otros temas \\ ¿Por qué obstinarse \\ en la fugacidad y el sufrimiento?
}

La ironía del texto se aclara en los versos siguientes: «Sus cadenas / resonaron de nuevo cuando el buitre / reanudó su tarea entrañable» (1986: 128).

46 «En los balances de nuestro trato con el desarrollo y la modernidad, no pueden perderse de vista los mastodónticos argumentos del desastre, pero tampoco las poco espectaculares cifras pequeñas, nuestros centavos, que a lo mejor no resultan ni cifras pequeñas ni tan humildes centavos. Hay que hablar de agua potable, de tanques de gas, de desagüe, de WC, de ropa barata producida en serie, de medios de comunicación masivos que además de baratijas electrónicas dan a la muchedumbre algo más de información y de lenguaje que la santería y los remotos púlpitos del pasado. La utopía de la gente moderna no fue nunca el paisaje de grandes ciudades con rascacielos ni de planetarios conjuntos industriales, sino de pobreza decente, al mínimo decente. [...] Muchos millones de mexicanos sí han logrado ese desarrollo; han logrado menor malestar, menor miseria, mayor dignidad que sus antecesores. Que los Apocalipsis del desarrollo adinerado y burocrático, que las catástrofes de la modernidad especulativa y salvaje de las élites, no les quite los grandes trofeos de su progreso propio, ni su desarrollo desde abajo, de su modernidad a contracorriente» (Blanco, 402). 
Evidentemente, para Prometeo, sometido a un tormento sin término, el sufrimiento es permanente y la experiencia de la fugacidad desconocida. Para Pacheco, no; y en este pequeño poema, el mexicano cuestiona y replantea su poética, que es, en gran medida, un asedio monotemático a estos dos motivos: sufrimiento y fugacidad. ${ }^{47}$ Había defendido el protagonismo del primero en "Dichterliebe», ${ }^{48}$ al afirmar que «la poesía tiene una sola realidad: el sufrimiento", citando los antecedentes de Baudelaire y Ovidio y garantizando así — confiado en la condición eternamente sufriente del ser humano«la supervivencia amenazada» de la poesía, ese «arte que nadie lee pero que al parecer / todos detestan» (77): un arte detestable, quizá, por insistir en temas que es más cómodo ignorar, pero resistente precisamente porque esos temas incómodos se niegan a desaparecer. Por otro lado, en "Contraelegía» se recalca la importancia de lo fugaz: «Mi único tema es lo que ya no está / Y mi obsesión se llama lo perdido / Mi punzante estribillo es nunca más» (125). Dos grandes temas y tópicos de la poesía: fugacidad y sufrimiento, el dolor metafísico frente a la precariedad de la existencia y el dolor físico del hambre, de la enfermedad, del envejecimiento y de la muerte.

Para tratar estos temas, Pacheco pronto se desprende de la solemnidad de sus primeros libros y se deja contagiar por las corrientes — «dominantes» en los años sesenta y setenta- de lo conversacional, lo antipoético y lo prosaico. ${ }^{49}$ «El mundo tiene hartura de la solemnidad de los profetas», dice un texto suyo de 1966, y efectivamente, la voz siempre atenta y crítica de Pacheco tiene plena conciencia de la relatividad de sus opioniones y de su incapacidad de distanciarse mentalmente del entorno. Por eso, su crítica es siempre, al menos en parte, una autocrítica, y rehúye la grandilocuencia y las grandes verdades del veedor omnisciente: «No lanzo cargos / desde ninguna altura pues yo también / soy parte y soy producto de la cloaca» (1983: 104). Es una poesía que se sabe obra de una época y de un país concretos,

47 Según Hugo Verani, la preocupación central de Pacheco sería «la fugacidad de lo vivido y el desgaste progresivo del mundo" (1993: 10).

48 En torno a este breve poema giró una curiosa polémica — no del todo inútilentre Hugo Rodríguez-Alcalá y Gabriel Zaid. Véanse los números 15, 16 y 18 de la revista Hispamérica (1976-1978).

49 Entre los precursores en esta línea, el más importante para Pacheco fue Ernesto Cardenal, a quien alude y cita en varias ocasiones, sobre todo en el significativo epígrafe de No me preguntes cómo pasa el tiempo (1969), el primer libro de lo que la crítica suele llamar la "segunda» —y más característica - etapa de su poesía. 
y contaminada por todos sus vicios y virtudes. Y aunque el yo se haga viajero y escriba desde y sobre el extranjero, ${ }^{50}$ su crítica de otros países siempre despierta analogías con la situación en su mundo; vuelve siempre contra lo suyo y contra sí mismo. No hay en Pacheco, por tanto, la confianza justiciera de un libro político como Canto general (por citar el mayor, quizá, en su género). Al contrario: «nada me ampara sino la lealtad a mi confusión» (1986: 63); «la incertidumbre es todo lo que tengo» (114).

Los temas de sufrimiento y fugacidad y esta actitud constantemente crítica y autorreflexiva del hablante convergen en el otro gran tema de Pacheco: la obra poética en sí y la defensa de su importancia y relevancia en el mundo actual. El poema, como todo lo humano, es pasajero: «Acaso nuestros versos duren tanto / como un modelo Ford 69 / - y muchísimo menos que el Volkswagen» (1986: 90); y la función del poeta no es más que la de ofrecer un «testimonio / del momento que pasa» (143). Pero evidentemente, si la poesía es efímera, las críticas que lanza no servirán para cambiar — ni efímeramente- el mundo. Por eso, aunque preocupado por el sufrimiento y la injusticia, el poeta se da amplia cuenta de la ineficacia de sus denuncias: aunque anhele un mundo sin víctimas, "cómo lograrlo no está en mi poder; / escapa a mi pequeñez, a mi pobre intento / de vaciar el mar de sangre que es nuestro siglo» (213). Sus «paginitas» y «hojitas» son inútiles: «no hacen peso en la balanza, / contra el horror creciente de este mundo»; intentan conjurar el sufrimiento ajeno —que «me duele tanto»- pero no las leerán «los aludidos, los muertos ni los pobres / ni tampoco / la muchacha martirizada». Circularán entre los mismos lectores, entre la media docena de elegidos de siempre. Lo único que le queda al poeta, por tanto, es lamentar su impotencia: «Y yo qué hago y yo qué puedo hacer» (1983: 57).

Y sin embargo, la poesía de Pacheco no es unilateralmente pesimista: va más allá —intenta, al menos, ir más allá — de la constatación implacable del dolor, del paso del tiempo y de la inutilidad del acto poético. Se intuye, en momentos, la esperanza de mejores tiempos. Así, Enrique Sainz encuentra un vaivén dialéctico en «esta experiencia agónica del poeta que

50 Sobre el tema del viaje y la figura del extranjero en Pacheco, véase el estudio de María Luisa Fischer (1998). 
percibe y padece la descomposición de un mundo y que entrevé la aparición de otro", o "entre las imágenes del caos y la caducidad, por un lado, y de la posibilidad de una plenitud anhelada, por otra parte» (1988: 147148). Y aunque la fugacidad domine la vida, en la misma "Contraelegía» citada arriba («Mi único tema es lo que ya no está», etc.), el hablante continúa: «Y sin embargo amo este cambio perpetuo / este variar segundo tras segundo / porque sin él lo que llamamos vida / sería de piedra» (1986: 125). El paso del tiempo permite que existan momentos, aunque breves, de plenitud; sin él, el sufrimiento (como el de Prometeo) podría eternizarse.

La visión que tiene Pacheco de la poesía también oscila, contradictoriamente, entre el desprecio y la exaltación; entre la perspectiva, quizá, de los que detestan y no leen la poesía y la de los que quisieran aferrarse a ella y confiar en ella como algo capaz, en su misma pequeñez, de resistir el flujo interminable y destructor de la existencia:

\author{
(La perra infecta, la sarnosa poesía, \\ risible variedad de la neurosis, \\ precio que algunos pagan \\ por no saber vivir. \\ La dulce, eterna, luminosa poesía.) [1986: 76]
}

Esta dulce, luminosa eternidad es la que busca Pacheco en sus llamadas «aproximaciones»: versiones de obras de diversos países y tiempos que él traslada (o aproxima) al contexto mexicano de su época, expurgando con libertad lo anacrónico y resaltando o rehaciendo los elementos aparentemente más universales e intemporales. Porque la poesía, o por lo menos alguna poesía, es capaz de vencer el paso del tiempo. Por eso, hasta en el espacio sórdido de un "hotel barato de una noche» (uno de esos onenight cheap hotels de Eliot) y en otro idioma (en inglés: "How beautiful you are, my dearest, how beautiful. I The curves of your thighs are like jewels...»), la lectura de El cantar de los cantares consigue trascender los siglos y emocionar al hablante: «En pleno Apocalipsis aún resuena / el eco de un deseo tan hondo / como para sobrevivir miles de años» (116). En efecto, la poesía, como la «belleza incomparable» de la música de Mozart, «justifica el mundo» y erige su humilde pero orgulloso desafío «contra el naufragio y contra el caos que somos» (1983: 61). 
Si Pacheco titubea en su valoración de la poesía, hay que recordar que está escribiendo en tiempos aparentemente prosaicos, "cuando la ciencia aspira a disfrutar / del monopolio entero de la magia» (1986: 78); en tiempos post-románticos y post-vanguardistas que parecerían haber sepultado las aspiraciones trascendentales y originarias de la poesía. Lilvia Soto ha asociado la obra del mexicano con lo que John Barth bautizó como «la literatura del agotamiento" (Verani, 108): cuando ya se ha escrito e innovado y experimentado tanto, sólo le queda al escritor reformular y recomponer lo ya hecho. Infaliblemente, por mucho que pretendas inventar, «cada vez que inicias un poema / convocas a los muertos» (1986: 143). O en palabras de José Miguel Oviedo: «la poesía de Pacheco, escéptica de su propio valor, hipercrítica, se apoya en una convicción iconoclasta, escribir la poesía no puede ser sino reescribirla, repetirla insinuando alguna variante que le dé alguna justificación y actualidad» (Verani, 54). ${ }^{51}$

\title{
La impronta moderna: aceleración de lo fugaz, proliferación del dolor
}

El leitmotif obsesivo de lo fugaz domina la poesía de Pacheco. Todo pasa, todo muere, todo acaba en polvo. Lo reitera el poema "La granada», cuando la voz de la fruta —orgullosa en su «húmeda perfección»— celebra la brevedad de su esplendor, la inminencia de su fin y la promesa de renacer en el perpetuo reciclaje de su especie, la dialéctica eterna entre la caducidad y la plenitud:

\author{
«... Seré putrefacción \\ o bien, devorada, \\ me haré sin duda carne de tu carne. \\ En ambos casos \\ (¿es necesario repetirlo?)
}

51 La crítica (Fischer, Soto, Michael J. Doudoroff) ha hecho hincapié en el uso de la intertextualidad en Pacheco. Me parece acertada la siguiente apreciación de Doudoroff: «Para mí, el aspecto más interesante de la intertextualidad es la manera en la que Pacheco ha neutralizado las fronteras entre la experiencia de la literatura y cualquier otro tipo de experiencia. Esto no quiere decir que vele o confunda "realidad" e "ilusión", sino que concilia todos los actos verbales, todos los textos, con un grado idéntico de estatus sin importar el origen de la experiencia a la que se refieran» (Verani, 167-168). 
regresaré a la tierra en forma de polvo

y desde ese polvo

(tú no)

reconstruiré mi perfección de granada». (1983: 46)

Son tópicos, ya se sabe (el propio hablante, entre paréntesis, lo reconoce): la mortalidad del individuo, la permanencia de los ciclos naturales. Realmente, ¿es necesario repetirlo?

Pero es algo más que una simple repetición. No me preguntes cómo pasa el tiempo, ese primer libro de la segunda y definitiva etapa de Pacheco, habla desde el título de una conciencia heracliteana, ${ }^{52}$ pero el epígrafe de Cardenal sitúa la preocupación en el contexto específicamente contemporáneo de las inquietudes metafísicas generadas por la modernidad y encarnadas en el mundo de la radio, los automóviles, la televisión y la música pop:
Como figuras que pasan por una pantalla de televisión
y desaparecen, así ha pasado mi vida.
Como los automóviles que pasaban rápidos por las carreteras
con risas de muchachas y música de radios...
Y la belleza pasó rápido, como el modelo de los autos
y las canciones de los radios que pasaron de moda.

El primer verso del libro insiste en este contexto: «Pertenezco a una era fugitiva, mundo que se desploma ante mis ojos» (1986: 59). Todas las eras son, sin duda, fugitivas; pero ésta más, muchísimo más. Aunque el tempus fugit haya marcado la poesía occidental desde siempre, se está fugando el tiempo hoy más rápido que nunca: para los modernos, en la célebre frase de Marx — canonizada como imagen de la modernidad por Marshall Berman (1983)—, "todo lo sólido se evapora en el aire». La misma lógica del capitalismo lo exige: el turnover incesante, el ritmo vertiginoso de la oferta y la demanda, la programada fugacidad del producto que mañana será desecho, todo se convierte en una gran metáfora rodante del tempus fugit, o en palabras de Pacheco: «un progreso bicéfalo (creador / y destructor al mismo tiempo / - y como el mismo tiempo) / al que no es fácil renunciar» (1986: 183).

52 Véanse los poemas «Don de Heráclito» (1986: 43), «Siempre Heráclito» (124), «Sol de Heráclito» (206) y el breve, magnífico «Río de las mariposas»: «Entre los nadadores distinguimos / a Heráclito el Oscuro / que hizo una señal de despedida» (136). 
Por otro lado (y por supuesto), a la par de la aceleración desbocada del tiempo, se ha multiplicado el sufrimiento en esta era de grandes relatos y grandes matanzas: de la guerra mecanizada, de Hiroshima y de Auschwitz. El salto cuantitativo en la capacidad destructora del hombre se constata con brutal franqueza en «Los vigesémicos»:

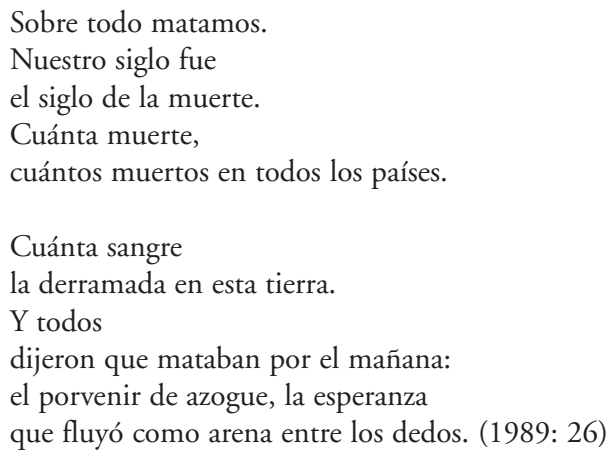

Así, los grandes temas de la fugacidad y del sufrimiento se escapan de su eterna y tópica reiteración. Son hoy nueva y doblemente relevantes, y servirán como la base para la problemática ecológica en Pacheco.

Crisis ecológica y la fractura de las analogías

Uno de sus primeros poemas «ecologistas», "Conversación romana», destaca el esfuerzo del autor por enmarcar su crítica de lo contemporáneo en un contexto más amplio; por proyectarse más allá de la contingencia y acercarse a lo que ayer no más se anhelaba como una poesía "universal». "Algo se está quebrando en todas partes», dice el hablante, pero los restos de la Roma moderna que observa — signos del desgaste ecológico- se imbrican sutilmente en el texto entre los restos monumentales de la ciudad imperial; la basura de hoy no es más que un reflejo cíclico de otra civilización que también, en su momento, se quebró: «Hay hierbas, / adventicias semillas en el mármol. / Desechos en las calles sin memoria: / plásticos y botellas y hojalata» (1986: 90). La historia se repite; una misma lógica la recorre y explica: las ruinas de hoy son las mismas ruinas de ayer. 
La búsqueda de analogías históricas o literarias es frecuente en Pacheco, cuyos retratos de un presente degradado pretenden así ser — parcialmente, por lo menos - arquetipos de la condición básica de la existencia (lo fugaz, lo sufriente). Los críticos han comentado esta tendencia alegórica (o analógica), que «nos hace sentir que el asunto, a pesar de su especificidad, apunta a temas y problemas esenciales» (Debicki, 236); o bien, en palabras de Thomas Hoeksema: «Sin una dimensión alegórica para universalizar el momento presente, se perdería la perspectiva de los acontecimientos contemporáneos. La naturaleza transformadora de la alegoría evita que Pacheco sea un crítico social» (Verani, 98). Ambos estudiosos -Andrew Debicki y Hoeksema - respaldan sus ideas con un verso de Baudelaire, que Pacheco traduce e intercala al comienzo de ""The Dream is Over"», un poema sobre la «muerte» de un lago canadiense:

—En el Erie no queda vida natural

-Como en México

(Todo ante mí se vuelve alegoria) [1986: 112]

«Le Cygne» (El cisne) de Baudelaire habla de la pérdida del antiguo esplendor parisino y del impacto de la modernidad en el espacio urbano como correlatos objetivos de las emociones del hablante y, a la vez, de la experiencia intemporal de la melancolía:

\footnotetext{
Paris change! mais rien dans ma mélancolie

N'a bougé! palais neufs, échafaudages, blocs,

Vieux faubourgs, tout pour moi devient allégorie,

Et mes chers souvenirs sont plus lourds que des rocs. (1981: 111)
}

París cambia, pero la melancolía del poeta permanece, y todo lo que observa, lo viejo y lo nuevo, lo lleva a trascender alegóricamente la contingencia. En una de sus frases más célebres, postuló Baudelaire que la poesía moderna tenía que hacer convivir lo eterno e inmutable (la base poética intemporal) con lo efímero y fragmentario (los rasgos de la época): "la modernité, c'est le transitoire, le fugitiv, le contingent, la moitié de l'art, dont l'autre moitié est l'éternel et l'immuable» (Calinescu, 57). Ahora bien, si la inclinación intemporal es frecuente en Pacheco, creo que la analogía de un poema como "“The Dream is Over"» funciona más bien a un nivel espacial: el hablante-viajero habla de otros lugares pero a la vez se refiere, analógicamente, a lo suyo: a lo mexicano; o bien, por extensión, 
a lo global. En efecto, el deterioro ecológico ofrece pruebas insistentes de que la situación actual desborda los hallazgos alegóricos y analógicos entre pasado y presente; el poeta reconoce que hemos entrado en una zona desconocida y la confianza en acceder a lo eterno y lo inmutable empieza a difuminarse en su obra. Para Hoeksema, la alegoría «evita que Pacheco sea un crítico social», es decir, que se pierda en la contingencia. Pero no es eso. Si no se pierde, es más bien por su lucidez al indagar las insuficiencias de lo alegórico, por su aguda conciencia de las aporías de nuestra época.

Las dos secciones de «Por Vietnam» ilustran bien, en sus contradicciones, esta creciente pérdida de confianza tanto en la eternidad de las leyes naturales como en la capacidad analógica de la dulce, eterna, luminosa poesía:

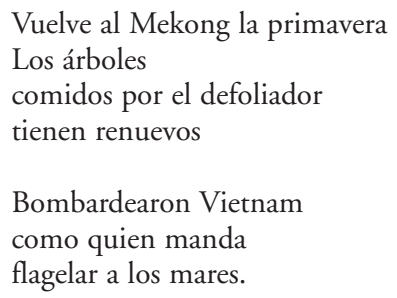

Como volvieron las golondrinas literarias de ayer, vuelve hoy la primavera en Vietnam a pesar de la brutalidad de los bombardeos y la agresión ecológica de las armas químicas. La violencia del hombre -incluso la violencia inestimablemente dañina del hombre moderno- es impotente frente al poder cíclico de la naturaleza: siempre habrá renuevos; desafiar la vida e intentar aniquilar un país es tan inútil como «flagelar a los mares». La dialéctica de muerte y vida, destrucción y resurrección, sigue intacta. Pero la segunda sección desconstruye esta especie de optimismo a largo plazo:

2

Dijeron que iban a defender el mundo occidental y que la revolución no pasaría

Hoy sus huesos blanquean los arrozales y entre el fango otoñal brillan las ruinas de sus latas y plásticos indestructibles. (1986: 139-140) 
La dialéctica se resquebraja. Los huesos entre los arrozales polvo serán - polvo rencoroso - pero las ruinas de esta modernidad, los desechos de Occidente, son «latas y plásticos indestructibles». No serán nunca polvo, sino muerte permanente, escarnio de los ciclos naturales. Es precisamente lo transitorio, fugitivo y contingente lo que se ha convertido en lo eterno e inmutable, como el envase de otro texto de Pacheco, que «dura segundos en la mano que lo desgarra: permanece siglo tras siglo en los sepulcros de desechos» (232).

Esta misma explosión de la dialéctica natural se encuentra en un poema posterior, «Orquídeas». No se trata aquí de un elemento artificial añadido a la naturaleza, sino de una especie sustraída a ella. Las flores representan "lo salvaje, lo vivo, / lo perdurable por efímero», pero la demanda insaciable del capitalismo — que las requiere como ornamentos para una «sala elegante» (como requiere también, siempre, más comida, mayores beneficios) - acarrea la explotación y la destrucción de su entorno natural y prepara su futura (y próxima) extinción:

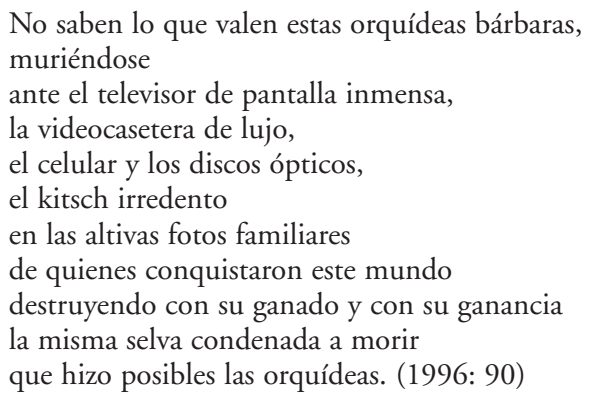

Se han invertido, definitivamente, los papeles: la barbarie natural está condenada a muerte; la civilización artificial será eterna en sus despojos.

\section{El reino de la ironía}

El mundo ha cambiado - lo estamos destruyendo - y al ritmo de la destrucción cambian, también, la visión y la poesía de ese mundo. Pero aunque las analogías comiencen a hacer agua y la confianza en lo inmutable se quiebre, Pacheco sigue yuxtaponiendo pasado y presente para resaltar, mediante el contraste irónico, el horror de lo que hoy ocurre. El poema 
"Idilio» reproduce, estructuralmente, los efectos disonantes de la modernización tecnológica. La mayoría del texto se entrega a la representación de un espacio paradisíaco (la naturaleza, la mujer amada, los inicios de la primavera, el olvido de las penas, la recuperación de la libertad: en fin, «el mundo / volvía a ser un jardín»), que en los últimos versos se encuentra violentamente negado: suena un "tañido funerario», interrumpe en el bosque "un olor de muerte», las aguas del mar «se mancharon de lodo y de veneno» y unos guardias ahuyentan a los amantes del «terreno prohibido / de la fábrica atroz / en que elaboran / defoliador y gas paralizante» (1986: 111112). De nuevo, salta a la vista la denuncia contra la guerra de Vietnam, pero lo que me interesa destacar es la insustentabilidad — para Pachecode los recursos poéticos tradicionales del idilio pastoril y del espacio arcádico. Al comentar este poema, Andrew Debicki vuelve a insistir en el sentido alegórico del texto: «La irrupción de los guardias y la pérdida del ambiente positivo representan en cierto sentido una nueva versión de un episodio mítico, la pérdida del paraíso terrenal» (Debicki, 233). Es posible que sea así; pero resulta más interesante, me parece, ver en este texto cómo la degradación ecológica se escapa de la analogía y va imponiendo cambios, tanto temáticos como estructurales, a la poesía. Los ciclos de siempre están rotos; hay mitos supuestamente eternos que han caducado.

«Lago Ontario» repite la estructura binaria de «Idilio». Empieza con una descripción embellecedora de un lago «que zozobra en el firmamento», arraigado en la intemporalidad — hay gaviotas «en permanente desbandada»-y resplandeciente con el $a z u l$ del ideal modernista. Pero el locus amoenus se revienta, hundiéndose al final en la realidad mortífera, indiferente al lirismo, de la contaminación:

\author{
Todo es azul mientras lo navegamos \\ todo belleza y calma \\ Hasta que al acercarnos a la ciudad \\ surgen las manchas pardas casi negruzcas \\ y los áisbergs de espuma sucia \\ de los letales detergentes (1986: 174).
}

Desde una perspectiva realista, ya no se puede idealizar un lago contaminado; desde la lucidez poética, ya no se puede seguir empleando un lenguaje y una imaginería anacrónicos. El péndulo de la poesía moder- 
na, que iba y venía - para Octavio Paz- entre la analogía y la ironía, vira definitivamente hacia ésta. ${ }^{53}$

«El infierno del mar» enfrenta explícitamente estos traumas. El mar se ha contaminado y sus connotaciones simbólicas, supuestamente perennes, han entrado en crisis. El hablante comienza autoimprecándose por haber empleado, él también, los tópicos "trascendentes» (mar-eternidad, mar-genetrix, etc.) y el lirismo — ¿o es cursilería? - de la forma femenina del sustantivo, al poetizar sobre el (la) mar: «Tú también, como todos, lo llamaste espejo de la eternidad, contrario de la tierra, camino que une, abismo que separa. $\mathrm{O}$, si la relación fue más estrecha, te refieres a ella como la mar, agua madre que en su interior gestó a todos los seres». La visión tradicional literaria ya no se sostiene; sólo hay que mirar la contaminación del mar para ver cómo se agotaron los símbolos heredados: «Si con Eurípides has creído que el mar lava la suciedad de este mundo, observa lo que desde esta orilla le arrojamos: plomo, cobre, mercurio, cianuro. Zarpa y verás los grumos de petróleo que han empedrado sus senderos. La muerte viscosa cubre de oscuridad la vida, infama el vuelo de las aves, en su lobreguez corroe a los peces» (1986: 229-230). La realidad viola la pureza de los ciegos lirismos. Paz sostuvo, en 1983, que la poesía de Pacheco «se inscribe no en el mundo de la naturaleza sino en el de la cultura» (Verani, 16). Pero «El infierno del mar» revela las aporías de los símbolos de raigambre puramente literaria y de una mirada «cultural» que va filtrando - y obnubilando - la «realidad» natural. Ver al mar compuesto de plomo, cobre, mercurio y cianuro vuelve obsoleta la imagen de Eurípides.

La constatación de esta nueva realidad del deterioro ecológico lleva a Pacheco a otorgar cada vez mayor importancia a la observación y la representación de la naturaleza. No sorprende, por tanto, encontrar una visión plenamente romántica en "Las ostras», del libro El silencio de la luna, donde la definición del arte como "atención enfocada» ilustra bien la nueva tendencia menos culturalista, y más atenta al entorno natural, de su poética:

53 Ironía y analogía son, para Paz, «los dos extremos que desgarran la conciencia del poeta moderno". Irreconciliables, "la primera es la hija del tiempo lineal, sucesivo e irrepetible; la segunda es la manifestación del tiempo cíclico: el futuro está en el pasado y ambos en el presente». Mientras la analogía se inserta en el tiempo del mito, "la ironía es la herida por la que se desangra la analogía» (1999: 482-484). En estos poemas de Pacheco, la fractura de la analogía y la herida abierta de la ironía son patentes. 
Pasamos por el mundo sin darnos cuenta,

sin verlo,

como si no estuviera allí o no fuéramos parte

infinitesimal de todo esto.

No sabemos los nombres de las flores,

ignoramos los puntos cardinales

y las constelaciones que allá arriba

ven con pena o con burla lo que nos pasa.

Por esa misma causa nos reímos del arte

que no es a fin de cuentas sino atención enfocada.

No deseo ver el mundo, le contestamos.

Quiero gozar la vida sin enterarme,

pasarla bien como la pasan las ostras,

antes de que las guarden en su sepulcro de hielo. (1996: 97)

Recuperar la curiosidad, abrir ojos, oídos y todos los sentidos hacia el entorno y volver a aprender los nombres de las cosas, son preámbulos necesarios para recuperar el respeto por el mundo y quizá, así, encontrar algún modo de remediar y poner fin a nuestra autodestrucción. Atribulado por la ciega indiferencia de los que prefieren gozar la vida sin enterarse del desastre inminente, el poeta se re-apropia de la voz profética que antes denunciaba. Es una cuestión de vida y muerte, se diría; y además, como en el último párrafo de «El infierno del mar», se trata simplemente de leer los signos para enterarnos de lo que viene:

Durante siglos pudimos injuriar [el mar] y saquear impunemente lo que sus olas resguardaban. Hoy al matarlo estamos muriendo. Cuando haya muerto el mar no tendremos oxígeno. El apocalipsis no bajará del cielo ni el mundo acabará con un sollozo. El infierno del mar se adueñará de nosotros y —última ironía y regreso a las fuentes- moriremos boqueando como peces fuera del agua. (1986: 230)

La visión bíblica del apocalipsis no sirve para describir el previsible cataclismo ecológico; tampoco sirve la imagen de los hombres huecos de Eliot, que cantaron a un mundo que en vez de estallar, se disolvía en un sollozo («This is the way the world ends / This is the way the world ends / This is the way the world ends / Not with a bang but a whimper»). Las referencias culturales consagradas, con la excepción del Infierno, ya no funcionan en este mundo atrozmente transformado. 


\section{Poesía apocalíptica y catastrofista: ¿en busca de un nuevo mundo?}

El apocalipsis no bajará del cielo, pero las últimas décadas han visto una notable resurgencia de la literatura apocalíptica. Como dice Lois Parkinson Zamora: «Nuestro sentido moderno del apocalipsis es más histórico que religioso: la palabra se emplea una y otra vez en referencia a los acontecimientos recientes de orden nuclear, bélico, ecológico, demográfico» (1994: 11). En términos estrictos, según esta autora, habría que distinguir la visión apocalíptica de la visión catastrofista, porque existe en aquélla siempre una tensión entre el pesimismo y el optimismo. Al fin y al cabo, las pestes y las tormentas de la Biblia representaron no sólo un castigo para los enemigos de Dios, sino también el preludio de un mundo nuevo y, por tanto, un consuelo para los creyentes. Así, «el Apocalipsis no sólo es una visión de condenación: para sus lectores originales era todo lo contrario, una luminosa visión del cumplimiento de la promesa de Dios, de justicia y de salvación común» (13).

Para un poeta religioso como Ernesto Cardenal -mentor de Pacheco en sus comienzos prosaicos-, esta visión binaria de un pesimismo encaminado hacia el optimismo se despliega en el célebre "Apocalipsis», que proyecta el discurso bíblico sobre las amenazas de la Guerra Fría:

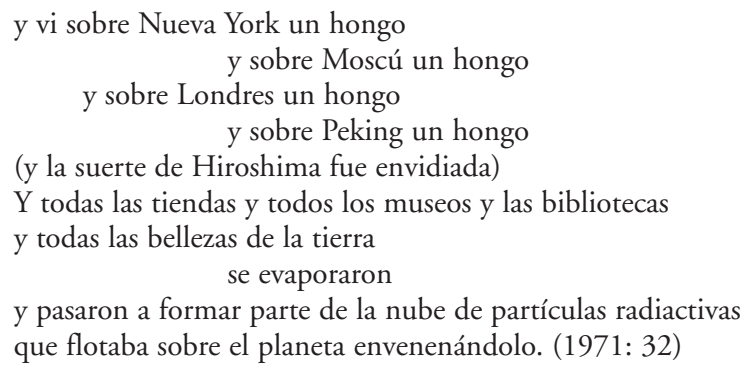

La larga enumeración de este cataclismo ecológico, erizada con solemnidad profética y con el lenguaje y la imaginería de San Juan, abre paso al final a otra enumeración - también solemne, pero ahora jubilosa- del nuevo mundo erguido entre las ruinas: $~ Y Y$ vi en la biología de la Tierra una nueva Evolución / Era como si hubiera surgido en el espacio un Planeta Nuevo»; la "especie nueva» producida por la Evolución es un solo orga- 
nismo armónico, una especie de Gaia compuesta no de individuos sino de hombres libres, y disfruta de un auténtico regreso al estado edénico: «y la Tierra estaba de fiesta / (como cuando celebró la primera célula su Fiesta de Bodas) / y había un Cántico Nuevo / y todos los demás planetas habitados oyeron cantar a la Tierra / y era un canto de amor» (35-36).

Pacheco, que carece del respaldo de la fe cristiana, ofrece una visión bastante más oscura, acaso más catastrofista que apocalíptica. En «El infierno del mar», lo que quedaba después de la asfixia por falta de oxígeno - el apocalipsis ecológico- fue un «regreso a las fuentes» que ya no cuenta, evidentemente, con la especie humana (1986: 230). Asimismo, en «Séptimo sello»—un poema que alude desde el título al Apocalipsis de San Juan y al clímax de la destrucción vengativa de Dios- el «último hombre» contempla un fin de mundo que ha sido provocado por las aberraciones consabidas: la contaminación y el consumo insostenible del agua, la deforestación, el envenenamiento de la atmósfera y la extinción no sólo (implícitamente) del mundo animal, sino también de la especie humana. A diferencia del poema de Cardenal, el relato bíblico ha sido despojado del desenlace optimista. La catástrofe no desemboca en ninguna promesa de redención, en ninguna esperanza de un mundo que brotará de las ruinas:

\author{
Y poco a poco fuimos devorando la tierra \\ Emponzoñada ya hasta su raíz \\ no queda un árbol ni un vestigio de río \\ El aire entero es podredumbre \\ y los campos océanos de basura \\ Soy el último hombre \\ Sobreviví a la ruina de mi especie \\ Puedo reinar sobre este mundo \\ pero de qué me sirve. (132)
}

La poesía de Pacheco mostró, desde muy temprano, su rechazo al antropocentrismo moderno que ha sido responsable por el desprecio y abuso del entorno natural. La «ebriedad de creernos, por mandato de Dios, amos eternos» (62) nos ha conducido a un estado de violencia y destrucción que ya en los años setenta podía interpretarse como la llegada del apocalipsis al "gran teatro del mundo»:

Cada noche del año atroz 1976 deja su cargamento de muertos en Beirut, Belfast, Buenos Aires, Montevideo, Santiago, Sudáfrica... Se abre la tierra, se desploman ciudades, los volcanes florecen de lava, el mar borra las poblacio- 
nes de la orilla, crece el desierto, aumenta el hambre, la violencia se adueña de los agonizantes centros urbanos. Seguimos viviendo el tiempo de los asesinos.

«No son signos del juicio final; se trata nada más de los terrores del milenio», dicen quienes observan como si estuvieran a salvo. "El mundo ha sido siempre el mismo; sólo que ahora estamos mejor informados. Vendrán tiempos mejores. No hay problemas». (223)

Las voces complacientes de siempre ignoran el alcance de la crisis (no quieren enterarse) y niegan la amenaza ecológica. Pero como hemos visto arriba, para Pacheco el mundo ya no es el mismo; el sufrimiento ha cambiado de manera no sólo cuantitativa, sino también cualitativa. Hoy sufre también la tierra, y estamos jugando con fuego, forjando la previsible extinción de la especie humana.

\section{Malpaís: los estertores de México D.F.}

«Malpaís», la cuarta sección del libro Los trabajos del mar (1983), lleva la poética del apocalipsis o de la catástrofe a la Ciudad de México. El primer poema se refiere a esta "ciudad de las montañas» en que los volcanes Iztacíhuatl ("caravana de nieve»), Popocatépetl ("cúpula helada») y el "azul y enorme» Ajusco han sido tapados por el «telón irrespirable» del smog, y en que la deforestación del valle circundante va convirtiendo todo en "asfalto o asfixia». En las últimas estrofas emerge una visión de un nuevo mundo posterior a la catástrofe: renacerán los volcanes y «el mar de fuego lavará la ignominia». Sin embargo, aunque brote entre las rocas alguna planta, «la nueva vida en el desierto de muerte» no contará con la presencia humana, sino sólo con esos «astros de ira, soles de lava, / indiferentes deidades, / centros de todo en su espantoso silencio, / ejes del mundo, los atroces volcanes» (1983: 71-72).

Los tres poemas siguientes ofrecen sendos avisos contra la catástrofe inminente: «Strada dell' Abbondanza» muestra la ciudad de Pompeya asolada (como la de México) por el crimen y la injusticia en «la víspera / del estallido del Vesubio» (73); «Recuerdos entomológicos (1982)» interpreta una plaga de hormigas como un indicio del fin: "Como otros animales se anticipan / a terremotos y desbordamientos, / en vísperas de crisis y escaseces / se multiplican las hormigas, cargan / con cuanto pueda preservar su especie» (74); por último, «Crónica mexicáyotl» vuelve a dar la palabra a 
los indígenas mexicanos derrotados en la Conquista: en libros anteriores, el lamento de los «vencidos» (su herencia una «red de agujeros») se imbricaba con el de las víctimas de Tlatelolco en 1968 (1986: 65-72); ahora el fin de su civilización se ofrece como una analogía de la próxima desaparición de México D.F. (1983: 75). ${ }^{54}$

Después de un breve texto que retrata a los gobernantes como monstruos — sanguinarios ladrones que «construyeron el sufrimiento»- los poemas finales de "Malpaís» se refieren a los restos de vida natural que sobreviven en la ciudad. En "Paseo de la Reforma», un fresno aparentemente eterno, un "monumento / a la belleza del mundo» que dejaba respirar y daba sombra a los ciudadanos, ya no aguanta la contaminación:

[...] ha muerto asfixiado
y masacrado con otros mil
por el gas venenoso que echan
los autobuses
en la innoble y letal colonia
penitenciaria
que hasta hace poco llamamos
ciudad de México. (77)

Los estragos de la crisis ecológica han hecho tanto daño a la vida urbana - una existencia carcelaria, asfixiante - que la ciudad (que hasta hace poco llamamos ciudad de México) pierde definitivamente su identidad, su nombre. Es el escalón anterior a su desaparición total. En el último poema de la sección, "Ecuación de primer grado con una incógnita», el fin vuelve a asomarse: en "el último río de la ciudad», el yo encuentra un pez casi muerto que boquea, «envenenado por el agua inmunda, letal / como el aire nuestro», una «última voz / de la naturaleza en el valle» que no logra, sin embargo, transmitirle su "palabra inexpresable»; sólo habla «el idioma / omnipotente de nuestra madre la muerte» (78). Es nuestra madre la muerte, que avanza, apoderándose de todo lo que hay en la ciudad, y cuyo abrazo se burla a mandíbula suelta de cualquier promesa de nuevos mundos.

54 En el espacio microcósmico de la ciudad, las estrategias analógicas y alegóricas siguen funcionando: hay ciudades y culturas que sí se han extinguido en el pasado. La extinción del hombre y la desaparición definitiva de la vida en el planeta son, en cambio, fenómenos nuevos que desbordan las analogías que nos ofrece la historia. 
Del antiguo binomio desaparece el elemento vida; se derrumba la dialéctica. Nos queda tan sólo un apocalipsis sin dios; un apocalipsis sin hombre.

\section{Conclusión}

La ciudad de México encarna todos los horrores de la contaminación urbana, pero una vez más, en Los trabajos del mar, Pacheco vuelve sus ojos al otrora símbolo de pureza y eternidad: «el mar sepulcro de las letrinas del puerto, / nunca mereció ser este charco que huele a ciénaga, / a hierros oxidados, a petróleo y a mierda» (20). Ni el mar ni la tierra ni el aire se merecen la destrucción a la que han sido sometidos. Y en la visión del poeta mexicano el planeta, como la Gaia que imaginaba Lovelock, se vengará del agresor. En efecto, los múltiples abusos de la ebriedad del hombre moderno - que ha terminado, según el canon postmoderno de Lyotard, fragmentándose en una incredulidad ideológica quizá paralizante- conducen al aniquilamiento indiferenciado de todo, incluyendo al ser humano. El catastrofismo de Pacheco no podría ser mayor: «ya progresamos hacia el fin del mundo» (20). 



\title{
CAPÍTULO 6. NOSTALGIA Y MILITANCIA EN HOMERO ARIDJIS: LA ESCRITURA EN UN MUNDO POLUTO
}

\author{
El esplendor de la naturaleza
}

Homero Aridjis, poeta, novelista, dramaturgo y ensayista, se ha convertido en una de las figuras públicas más importantes de la defensa del medio ambiente mexicano, notablemente en su papel de fundador y codirector del Grupo de los Cien, una organización de escritores, artistas y científicos que luchan desde los años ochenta contra la contaminación de la Ciudad de México y en defensa de especies amenazadas como la mariposa monarca, las tortugas marinas y la ballena gris. El desarrollo de una vertiente ecologista surge en la obra de Aridjis en los años setenta, y llega a su culminación en Tiempo de ángeles (1994); a la vez, novelas como La leyenda de los soles (1993) y ¿En quién piensas cuando haces el amor? (1996) denuncian la hiperurbanización e hipercontaminación de la capital mexicana en tremebundas visiones apocalípticas del futuro.

En los primeros libros de poesía de Aridjis, el mundo natural es un espacio rebosante de vitalidad y la fuente de la trascendencia. La naturaleza arde, sueña y canta. Todo — animal, montaña, árbol y espesura — posee su significado particular; todo participa en el gran himno sagrado de lo vivo:

$$
\begin{aligned}
& \text { El verano en lo cálido es un nido } \\
& \text { un reino que arde soñoliento } \\
& \text { una animalia verde y viva }
\end{aligned}
$$


bestias sagradas por el rigor del sol montañas móviles con sueños y organismos plantas del aire con las hojas meciendo en sus cimas un insecto

ramas que suben y bajan temblando soleadas sobre la sombra sobre el río espesuras que el azul penetra abren aquí un ojo allá una flor

en la raíz más honda y en la oreja más alta un alboroto intenso un crecimiento ávido se derraman como una acción de gracias

cada criatura cada sombra cada eco levantan hacia el día que comienza un canto trémulo de delgados himnos. (1994: 151)

El poeta ha tocado lo trascendente en esta explosión vital del amanecer. Las connotaciones religiosas de la acción de gracias y de los delgados himnos son rasgos característicos de esta época de Aridjis y se repiten en cantos a la creación fundadora del espacio originario, pero también a la creación permanente que sigue multiplicando sus dones, «una creación en el movimiento / que juega en el esplendor de la animalia pura / y navega armoniosamente por el alma / de esta arca de lo vivo» (167-168). El vocablo animalia, aquí como en el poema de arriba, evoca la armonía esencial de la naturaleza: los animales forman un solo organismo, deslumbrante en su pureza edénica.

Guillermo Sucre destacó en estas primeras obras de Aridjis una falta de "historia" o "geografía" bien definidas y localizables», afirmando que la mirada del poeta se centraba en «el esplendor mismo del universo, y no su mero inventario». Por eso, su poética podía resumirse en dos versos: «El único milagro es el de la Creación / lo demás es anecdótico»; y Sucre añade: «entendemos que la Creación simultáneamente alude a la poesía y a la naturaleza» (1975: 360-361). Ciertamente, la mirada del poeta lo conduce a una comunión mística con el universo: «Y siendo de la sustancia del misterio / nuestro ser abre los ojos / para ver la inmensidad sagrada»; y la mano con la que escribe es «movida por el ser eterno». Así, el contacto del poeta con el mundo natural lo adentra en el espacio de la creación continua, permitiéndole traspasar las fronteras de la contingencia y acceder al umbral de lo sagrado. 
Esta relación se revela también en la imaginería natural, de estirpe romántica, con la que habla el poeta del proceso creador. Él escribe con la misma naturalidad del árbol, zarandeado por la tormenta, que deja caer su fruta:

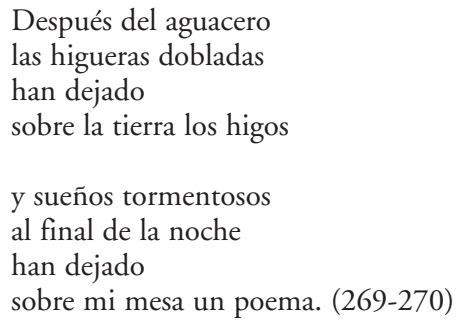

Las imágenes naturales y cósmicas se incorporan también a la visión del amor como camino hacia la trascendencia, una fusión de dos cuerpos y su total integración en el universo: «nubes grises bajo nubes claras visten el cielo / y como ríos que confluyen y entran y salen uno de otro / nuestros cuerpos se revuelven en el lecho común // y sobre ella o yo no sé qué espuma soy qué onda / el sol sobre la espalda es leve» (162).

\title{
La pérdida del esplendor
}

Sin embargo, la abstracción y la intemporalidad señaladas por Sucre pronto se pierden en Aridjis, y el esplendor de la naturaleza empieza a adoptar formas particulares y asentarse en una geografía y una historia propias. Lo sagrado adquiere nombre y el yo se convierte en un protagonista enraizado en un tiempo y un lugar determinados, en el pueblo de Contepec y el Cerro Altamirano de la infancia del poeta, espacios recordados y recreados como un paraíso:

\author{
Éste es el puente \\ por el que yo pasaba \\ a lo lejos se veía la montaña \\ alta de amor \\ y el río que alejándose \\ todavía no se ha ido
}


tal vez en mi ser

se hallaba el paraíso

o detrás de los árboles

era verdad la vida. (217-218)

Un poema posterior, «Autorretrato a los 16 años», sitúa al yo adolescente explícitamente «entre los pinos del Altamirano» y celebra la libertad de esos días, anteriores a la caída de la madurez y a la atracción ineludible de la urbe, que «no tienen nombre ni fecha, / ignoran la jaula de las horas, / son iguales a un deseo / que puede figurarse ayer o mañana». La integración del joven en la naturaleza de su entorno es intensa, semejante a una relación de amor físico, y lo marcaría para siempre: «Lampiño, flaco, pelilargo, / él hace el amor con todo: / con la calandria, con la encina, / con la mariposa, con la distancia». Es un amor que afila sus sentidos, que le revela el lenguaje de los animales («En el cerro brama la cierva, / se oye el tauteo de la zorra») y le enseña a ver e impregnarse del mundo del bosque: «sus ojos entran en la maleza, / ebrios de lluvia verde. / El sol amarillea su cara, / pinta sus manos de poniente, / él deja su sombra entre los pinos» (360). La compenetración es absoluta, y sin embargo el lenguaje impone un divorcio irreparable: el uso de la tercera persona abre un abismo entre la adolescencia (lejana y maravillada) y el presente del hablante, que éste intenta obviar al rescatar en la memoria $-\mathrm{y}$ recomponer en la escritura - las huellas de la plenitud juvenil.

Como en su primera etapa, el amor y la palabra poética, que el yo sigue ejerciendo en su madurez, son experiencias arraigadas en el mundo natural, aquí en el espacio concreto de la infancia. Así se puede ver en la enumeración de lugares, seres y fenómenos, destacados en toda su inmediatez, de «Aquí esta el cerro Altamirano»:

\author{
Aquí está el cerro Altamirano \\ aquí está la víbora de cascabel \\ aquí está la Cañada del Pintor \\ aquí está el jilguero vibratorio \\ aquí está la mujer parada \\ aquí está el hombre que entra en la mujer \\ aquí está la casa de la voz \\ aquí la lengua que habla. (313)
}

Sucre veía en Aridjis el esplendor mismo del universo, y no su mero inventario; pero ahora el esplendor surge precisamente de esta especie de inven- 
tario tejido en torno a los lugares de la infancia, y recreado - a través del tamiz de la memoria - por un hablante mayor que hurga en las raíces de su mirada y su voz. Un acontecimiento cotidiano — un rayo de sol que cayó, años atrás, entre las ramas de un fresno- puede hacerse presente, trascender su instantaneidad y cobrar sentido epifánico para el poeta-adulto: «Por esa luz sin nombre / por el anhelo de hacerla mía / he caminado desde entonces / he trabajado" (253).

En cierta medida, Aridjis pertenece a la familia de poetas modernos — como Rilke, Dylan Thomas y Jorge Teillier- que han vuelto, desde la nostalgia soñadora de su madurez, en busca de los lares y lugares de la infancia, idealizados ya por el paso del tiempo y la conciencia de la pérdida. Así, afirma no querer "más que aquel día contigo en mi tierra perdida» (171); o dice, en prosa poética: «El hombre que en un momento tormentoso de su vida [...] dormido sueña con la casa natal y se ve niño otra vez [...] comprende que sólo en sueños podrá volver a la casa paterna» (277). Sin embargo, la pérdida del mundo infantil de Contepec y de los bosques del Cerro Altamirano no se debe sólo a la fatalidad de la distancia temporal, sino concreta y brutalmente a la destrucción material de ese mundo. En Quemar las naves (1975), el mismo libro en que se da nombre por primera vez a los lugares sagrados de la infancia del poeta, se intercala el anuncio — "Profecía del hombre»— de un inminente cataclismo ecológico: nubes contaminadas, ríos muertos, aves, peces, ballenas y elefantes en peligro de extinción, montes talados, y seres que caminan enmascarados y solitarios por una "ciudad sin aire», en la que el sol se parece a "una yema arrojada en el lodo» (224).

Dos décadas después, Aridjis escenifica la destrucción del entorno de Contepec en un poema sobre la mariposa monarca, una especie que invierna en los bosques de oyamel del centro de México (entre ellos el del Cerro Altamirano $)^{55}$ antes de migrar cada abril al sur de los Estados Unidos. La defensa de la mariposa monarca ha sido un foco principal de la labor ecologista del Grupo de los Cien, y se entiende perfectamente que la emotividad de esta lucha tiene, para Aridjis, una motivación doble: la tala del oyamel destruye no sólo el hábitat de la mariposa monarca, sino

55 Estas mariposas monarcas tienen un protagonismo notable (desde el título) en la novela autobiográfica de Aridjis, La montaña de las mariposas (2000). 
también, simultánea e inextricablemente, el espacio —elevado en sus recuerdos y poemas al rango de un paraíso- de su infancia.

Durante la noche, los bosques de mi pueblo aguardan escarchados las luces del amanecer. Las mariposas monarcas, como hojas cerradas cubren el tronco y las ramas de los árboles. Superpuestas una sobre otra forman un solo organismo. [...]

Es mediodía. En el silencio perfecto se escucha el ruido de la motosierra que avanza hacia nosotros tumbando árboles y segando alas. El hombre, con sus mil hijos desnudos y hambrientos, viene gritando sus necesidades y se lleva puñados de mariposas a la boca. (1997: 32)

La carga intimista de la primera persona (son «los bosques de mi pueblo»), la armonía y unidad de las mariposas dormidas («un solo organismo») y la perfección del silencio se contraponen nítidamente a la estridencia del hombre moderno - armado con su motosierra- que irrumpe en el bosque matando mariposas. El choque entre las necesidades del hombre - el hambre y el frío de esos mil hijos, fruto de la explosión demográfica- y las de la naturaleza no humana termina, previsiblemente, con la masacre de ésta y con la violencia grotesca del agresor que se lleva, gritando, "puñados de mariposas a la boca». Las tintas están cargadas contra semejante barbarie ecológica, pero el poema no rehúye el reclamo del humanismo antropocéntrico (el ser humano, como centro del universo, dispone de la naturaleza a su antojo; la muerte de otra especie no vale nada al lado de los intereses del hombre) y su repudio de un ecologismo que proclama la armonía desjerarquizada entre todos los seres vivos.

\section{Una poética despojada de sus raíces. Entre la ironía, la elegía y el silencio}

«Aquí está el cerro Altamirano» concluyó con los versos: «aquí esta la casa de la voz / aquí la lengua que habla». La ecología es la ciencia del oikos, de esa morada en que las diversas especies conviven y cíclicamente se prolongan en el tiempo. En el caso de Aridjis, el oikos de la naturaleza de su infancia fue desde el comienzo la raíz y fuente de su poesía, la «casa de la voz». Resultaba, por tanto, inevitable que la amenaza al entorno infantil 
traumatizara su mirada y lo impulsara a cambiar de poética. La destrucción presente y futura ensombrece el recuerdo del pasado, como se ve, con toda la fuerza de la nostalgia, en un texto que no sólo lamenta la pérdida, sino a la vez anticipa la infinita pobreza e incertidumbre del poeta-hablante que está siendo desprovisto de sus raíces:

Arrasado el bosque de tu infancia, ¿adónde voltearás

para hallar tus pasos que no hicieron camino en el día verde?

Cortados los oyameles de tus años de niño, ¿adónde escucharás

la voz del poema, que como serpiente herida, volaba entre las ramas?

Caídos los muros de tu casa, ¿adónde descansarás

cuando la tiniebla invada las cavernas de tu cuerpo?

Talado y quemado el cerro de tu pueblo, ¿a qué cima llegará

la mariposa Monarca, imagen de la resurrección del invierno? (1994: 435)

Aridjis va a arraigar su nueva poética en estos temas de desarraigo y destrucción, y su obra se irá haciendo progresivamente más ecologista en sus denuncias y exigencias, en sus ironías y en su representación catastrofista de paisajes arrasados por el hombre.

En el ensayo «El milenio del sol», Aridjis examina cómo el concepto de la naturaleza ha sido reformulado por los escritores y artistas del siglo $\mathrm{xX}$, testigos de la crisis ecológica mundial:

Ciertamente la observación del mundo natural, como fue expresada en el Himno a la Tierra homérico y en Las Églogas de Virgilio, en los trovadores, en Gonzalo de Berceo y en los libros de horas medievales, ha cambiado, de acuerdo con la situación lamentable a la que ha llegado el mundo natural en este fin de milenio. El paisaje que se plasma en la literatura contemporánea ya no es el de un ambiente de cuento de hadas o de una Arcadia legendaria, es el que nos ofrecen las posibilidades estéticas de la contaminación y las de la observación del deterioro global. El escenario idílico de los tiempos primordiales, cantado por los poetas de Oriente y Occidente, y descrito por los autores de novelas pastorales, se quedó en la memoria de los hombres como el sueño de un paraíso abolido. (2000a: 8 )

Los símbolos supuestamente intemporales de la naturaleza se cargan de temporalidad y se quiebran. El bosque encantado de los cuentos de hadas también se ha contaminado y se ha ido derribando al ritmo de la tala de árboles en el Cerro Altamirano. La visión paradisíaca del mundo natural desaparece como presencia en Aridjis y volverá, a partir de ahora, sólo como recuerdo —el sueño de un paraiso abolido - o en el momento de su pérdida, contrapuesto abruptamente a la avaricia insaciable del hombre contemporáneo. 
La representación del Nuevo Mundo como una especie de Edén —un tópico desde las primeras exclamaciones colombinas - siguió, hasta hace muy pocas décadas, intacta y seductora para muchos escritores hispanoamericanos (piénsese, por ejemplo, en el Carpentier de Los pasos perdidos). Aridjis presenta, con cruda tristeza, el fin definitivo de esta utopía. La Amazonia -espacio paradigmático de la pureza en el discurso ecologizante contemporáneo- se convierte en «el desierto más grande del mundo», un "paraíso en ruinas» en que "el último jaguar corría entre los tocones», perseguido por la muerte (1997: 56). Otro poema, «Nueva expulsión del paraíso", contrasta las formas rituales aztecas — cuya función fue la de prolongar los ciclos y conservar la relativa armonía con el entorno- con el holocausto de los animales eliminados en masa para saciar, cada día, nuestras multitudinarias necesidades humanas. Lo único sagrado para el hombre contemporáneo es el apetito. En nombre del apetito se mata al prójimo, sea éste hombre, animal o la tierra misma:

No es la piedra de los sacrificios, es el rastro donde el hombre degüella a los carneros.

Es el burdel de terneras abiertas en canal, en las vidrieras de la mañana.

Es el paisaje de huesos blancos, de muslos y médulas, de corazones y costillas.

Es la carnicería de conejos pelados, corriendo sin patas, de cabeza en el garfio.

Es el cerdo sobre las brasas, mirándonos con ojos blancos cocidos hablándonos con el hocico cosido.

Es el altar del apetito donde el hombre sacrifica a la vaca, al gallo y al cordero.

Es esta hembra del hombre que se llama hambre, hambre de muerte. (1984: 430-431) 
La ironía grotesca que articula este contraste entre la ritualidad azteca de antaño y el materialismo actual, acentuada por el tono aparentemente impasible del yo en su exposición de los diversos rostros de la muerte, se convierte en una de las columnas vertebrales de la poesía de Aridjis. El deslumbramiento de la Creación fue un factor central en su poesía temprana; el proceso creador se somete ahora al desgaste corrosivo de la ironía y la parodia. Así, un hablante que se autodenomina "hombre lobo" puede declarar que «lo que Dios hizo en seis días, / yo lo deshago en uno» (447); y la misma parodia del Génesis bíblico se reitera en una escueta «Descreación»:

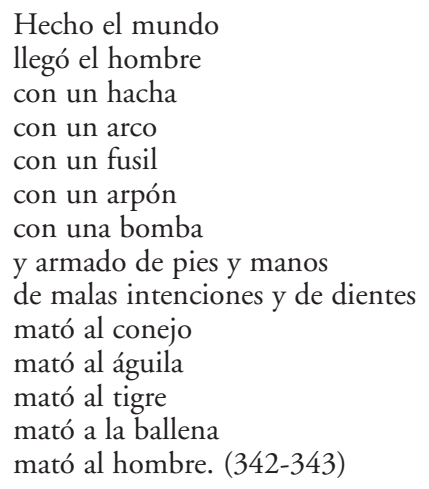

Inexorablemente, el círculo de la destrucción se vuelve, al final, contra el propio hombre-destructor. Afanado en la «descreación», éste termina descreándose a sí mismo.

La conciencia que tiene Aridjis de estar reescribiendo, como ecologista, no sólo la poesía paradisíaca de su primera etapa sino también textos del canon literario y religioso, vuelve a notarse en su curiosa representación de los ríos. El poema llamado, precisamente, "Los ríos» comienza con un compendio del imaginario fluvial de la tradición, resumiendo una serie de explicaciones geográficas e interpretaciones mitológicas, y exponiendo el simbolismo religioso y ritual que han tenido los ríos en distintas culturas. La segunda parte del poema retrata, en contraste, la transformación de los ríos mexicanos que antes bajaban rutilantes a Tenochtitlán, y en los que «hoy van mugiendo entubados, menguados, / pesados de aguas negras, crecidos de mierda / [...] / avanzando a tumbos por la ciudad desflorada, / desembocando en los lagos letales, / y en el marcado mar, que no los ama» (398). Pero el contraste entre mito 
y realidad, entre rito y actualidad, no se limita a esta oposición entre tiempos premodernos y la (post)modernidad actual. Aridjis sabe que tampoco los grandes poetas modernos - del siglo XIX y comienzos del siglo XX- han experimentado semejante crisis ecológica y la crisis simbólica que ella desencadena en el arte. Por eso, en "Ríos de poetas», el Tajo de Pessoa, el Neva de Pushkin, el Sena de Apollinaire y el Guadalquivir de Lorca también se contraponen tajantemente a los suyos: «me hacen pensar en los ríos / entubados, pútridos, muertos / de esta ciudad que un día / con sus naves hundidas, / se ahogará en su sed» (449).

Antes toda la naturaleza entonaba su «canto trémulo de delgados himnos» (151); ahora - y si no es ahora, será en el futuro próximo que esta poesía presenta-, el planeta despoblado de especies ha caído en el silencio y el poeta asume el papel de recuperar los lenguajes perdidos u olvidados y de leer los signos de un pasado que palpita por debajo de las ruinas del presente. La suya es lo que Octavio Paz llamó la otra voz de la poesía, "la del hombre que está dormido en el fondo de cada hombre» (1999: 702), la que puede ayudarnos a sobrevivir. "Ya he indicado», escribió Paz, "que si naciese un nuevo pensamiento político, la influencia de la poesía sería indirecta: recordar ciertas realidades enterradas, resucitarlas y presentarlas. Ante la cuestión de la supervivencia del género humano en una tierra envenenada y asolada, la respuesta no puede ser distinta» (704). Por eso, en el poema "Animalia», cuyo título remite a los primeros textos celebratorios de Aridjis, las preguntas retóricas se impregnan de una nostalgia elegiaca por las realidades enterradas:

\author{
¿Qué dijeron los loros en la selva \\ antes de emprender el vuelo hacia la noche? \\ ¿Qué dijeron las tortugas marinas \\ antes de fenecer sobre la arena? \\ ¿Qué dijo el venado cola blanco \\ antes de ser cazado entre las zarzas? \\ $\mathrm{El}$ águila real, el puma, el zopilote, \\ la nutria, el quetzal, el mono araña, ¿qué dijeron? \\ Su silencio es lo único que oímos, su silencio. (1994: 431)
}

En este silencio de muerte, el poeta va escarbando y rescatando los restos del pasado. Sólo a él y a los ángeles — cuyo lenguaje es el de los sueños, de las "palabras interiores» y de la poesía (1997: 7) — les será permitido superar el silencio y retener el pasado, acceder a lo perdido con una imaginación sensorial cargada de sinestesias: «Él caminaba por la selva per- 
turbada, / oía la fragancia de las plantas suprimidas, / palpaba el gorjeo de los pájaros extintos, / veía los follajes de las vegetaciones calcinadas» (125).

Pero si el poeta en su papel angelical procura, a veces, aferrarse nostálgicamente al pasado, también formula nuevos lenguajes, adecuados para un mundo nuevo y terriblemente cambiado. Así lo muestra «Palabras que reemplazan las palabras»: si se altera la realidad —en vez de ríos llamados atoyatl, hay calles de cemento; en vez de los árboles teocotl, postes de luz pública-, el lenguaje no tiene más remedio que adaptarse a ella (1994: 313) y el poeta, en vez de leer el libro de la naturaleza, tiene que aprender a descifrar el lenguaje de la ciudad contaminada: «leo sobre el mar de coches / las letras de plomo / que forman en el espacio de la mañana / el vaticinio del fin próximo / de la vieja Tenochtitlán» (318). Al interpretar estos nuevos códigos, podrá recuperar el antiguo papel de poeta-profeta, anunciando y denunciando la catástrofe venidera que vislumbra.

Consciente del fin inminente, Aridjis se ha convertido en un poeta de la decadencia — de la nueva, tangible decadencia ecológica de Occidente-, y ha vuelto a interesarse por los crepúsculos de los simbolistas (ahora ensuciados o ensangrentados por el smog) y por «los seres en sus últimos momentos» (301). En la selva desértica, mientras vuela una guacamaya en vana búsqueda de árboles donde posarse, el ángel ecológico observa un páramo de destrucción embellecido por el crepúsculo: «el ángel, parado al borde de una barranca, / veía, sediento, el fin del día sanguinolento» (1997: 55).

Dentro de este mundo degradado, el ser humano - nutrido con su «smog de cada día» (1994: 435)—, se ha contaminado irremediablemente; al fin y al cabo, el aniquilamiento del mundo no es más que una materialización del vacío espiritual del hombre: «El hacha del espíritu / es la que derriba más árboles» (434). Mientras la naturaleza y el lenguaje cambian, cambia también el amor. En «Poema de amor en la ciudad de México», la contaminación aún no impide la fusión de los cuerpos y el vivo esplendor del acto sexual: «Entre paquetes humanos y embotellamientos de coches, / por plazas, mercados y hoteles, / conocimos nuestros cuerpos, / hicimos de los dos un cuerpo» (397). Pero es un caso aislado: el amor sufre el mismo desgaste que su entorno. Así, en "Canción de amor en la ciudad poluta» los amantes abrazados no son más que «sombras amarillas» dentro de la multitud (1998: 54); y en un texto de "Lugares y dioses rotos» —un título que insinúa una destrucción tanto ecológica como espiritual—, se ofrece una 
imagen curiosa de seres mutilados, física y emocionalmente incapacitados para amar en un mundo contaminado:

\author{
No me des de esta fruta \\ que se come con los labios; \\ con esa media boca \\ que te queda, \\ el amor es la muerte. (1994: 466)
}

Por último, en otro poema catastrofista, «Descenso a la ciudad poluta» —una bajada al infierno ecológico de México D.F.—, todo el panorama de ruinas de la capital se remata con una visión del fin del mundo en la que el tráfico atascado se ha transformado en una procesión (funeraria) de coches y donde el beso de los amantes emana, grotescamente, de una boca «metálica y viscosa»:

\author{
Antes de que desciendas a la ciudad poluta \\ mira el cielo amarillo que te envuelve \\ como un vasto sarape desgarrado, \\ mira allá abajo la amiba que te espera \\ comiéndose a sí misma. \\ Antes de que desciendas al lugar donde la luz se olvida, \\ mira la mañana ebria de ruidos, \\ la catedral hundida como un barco gris, \\ las estatuas Fe, Esperanza y Caridad \\ volver hacia ti el rostro cacarañado. \\ Mira a la gente de sombra descolorida, \\ los cerros pelones que saludan tu arribo, \\ los perros, los niños y las margaritas \\ sufrir la muerte amarga de la lluvia y el aire. \\ El día aquí es un árbol marchito descuajado, \\ el beso aquí es una boca metálica y viscosa, \\ el tiempo aquí es una larga procesión de coches \\ camino al funeral del hombre. (463-464)
}

\title{
Epílogo: las novelas apocalípticas
}

Paralela a esta poesía ecológica, la narrativa de Aridjis ha ido desplegando sus preocupaciones apocalípticas en retratos pesadillescos del mundo 
venidero. Ya en 1982, en las tres novelas cortas de Playa nudista, se asoman los motivos centrales de su narrativa posterior: «Playa nudista», situado en Holanda, retrata el automatismo sexual en una sociedad atrozmente materialista; "Noche de independencia» ofrece una visión igualmente alienada de la Ciudad de México; y «El último Adán» presenta un terrible inventario de un mundo devastado por un holocausto nuclear. Como en algunos de los poemas comentados, la destrucción se representa como una irónica desconstrucción de la creación genésica:

Era la descreación anónima, el despojo radical, el rencor tenaz que rápidamente borraba de sus ojos al venado y a la orca, al cóndor y al quetzal, al delfín y al elefante, al colibrí y al oso, al tigue y al papagayo, a la abeja y al león, al pingüino y a la jirafa, al fresno y al álamo, al girasol y a la buganvilla, a la mujer y al hombre, al agua y al aire, al fuego y la tierra. (1982: 172)

En las novelas La leyenda de los soles (1993) y ¿En quién piensas cuando haces el amor? (1996), Aridjis ha retratado la Ciudad de México en el año 2027, en los últimos días de lo que para el calendario azteca es la era del "Quinto Sol» y que supuestamente acabará, según la mitología indígena, en una sucesión de terremotos. La ciudad "fuera de quicio» (1996: 22) se encuentra asolada por el colapso ecológico y social: la corrupción de los políticos y la policía, el crimen descontrolado en las calles, el narcotráfico, los secuestros y asesinatos, las violaciones, las perversiones y la omnipresente prostitución atemorizan a unos ciudadanos estupidizados por los medios de comunicación, enajenados del mundo natural y totalmente incapaces de relacionarse los unos con los otros. Hay sociedades de Violadas Anónimas y de Neuróticos Anónimos, la gente habla y habla sin escuchar (42) y ya nadie se interesa por las bibliotecas, las librerías y el teatro (111).

La falta de agua domina la vida ciudadana. La leyenda de los soles comienza con la frase: «En la ciudad de México no había agua» (1993: 11). Resultaba normal que «de los lavabos no saliera más que un ahogo» y que hubiera que hacer cola para comprar agua (17-18). La situación se había deteriorado hasta tal punto que era más fácil preparar un café con champaña, tequila o vino tinto que con agua (21). A la vez, el aire se había hecho irrespirable: a través del «manto cafesoso de la contaminación» (24), el sol brillaba como una "clara de huevo podrido» (30) o como una "yema viciosa» (112). En la ciudad moribunda, la naturaleza había sido reemplazada con burdas imitaciones artificiales: los parques estaban llenos de 
árboles de metal y pájaros autómatas. Pero la destrucción cometida por el hombre se extendía también al campo. Se leían, en los periódicos, los últimos obituarios por «la extinción del lobo mexicano, el fin de la palmera nakax en Sian Ka'an, la desaparición de una orquídea en Los Tuxtlas, la muerte del Río de las Mariposas. Por esas muertes no se podía dar el pésame a nadie. Esas criaturas no tenían dueño» (1996: 48).

La extinción de los animales es un tema constante en estas novelas. En un escaparate, la protagonista y narradora Yo Sánchez encuentra el último mono araña del Desierto Lacandón (213), y en el Parque de Conservación Ecológica ve un mamífero «ebrio de contaminación»: la última jirafa del planeta (87). Y en La leyenda de los soles, la media hermana del jefe de la Policía, general Carlos Tezcatlipoca, es una "ecoguerrillera» que ha formado una reserva para animales en peligro de extinción. Antes de matarla - y con ella a todos sus animales-, el general comenta a un cómplice suyo que «pertenecemos a la generación humana que verá viva por última vez a la Laúd, la especie de tortuga marina más grande que se conoce. La consideraba extinta, allí hay una. Ahora la fusilaré delante de tus ojos» (1993: 70).

En ambas novelas, la degradación tiene alcances planetarios: hay noticias sobre guerras ecológicas, sobre hambrunas en el desierto más grande del mundo (la Amazonia); noticias «sobre las exequias simbólicas del mar Mediterráneo, sobre ríos biológicamente muertos, sobre emergencias ambientales en El Cairo, Atenas y Santiago, sobre terremotos y erupciones volcánicas en Colombia, Perú, Estados Unidos, China, Japón, Irán, Grecia, Turquía, Italia y Portugal» (85).

Pero el tono de las novelas no es unilateralmente catastrofista. El desmoronamiento final de la ciudad, anunciado por pajarracos negros, por la llegada de los temibles tzitzimitl y tzitzimime de la mitología azteca y por los terremotos, ofrece al menos - fiel a la tradición del apocalipsis bíblico- la posibilidad de una regeneración posterior en la era del Sexto Sol. Al final de La leyenda de los soles, los protagonistas-amantes — el pintor Juan de Góngora y la fotógrafa Bernarda Ramírez - vuelven a ver los volcanes Popocatépetl e Iztac Cíhuatl, antes tapados por el smog, "con su limpidez original» y en la punta de un cerro «vieron la figura azul de una mujer que tenía los brazos extendidos hacia el Sol, como si quisiera tomar de él el calor y el esplendor de la mañana. En su mano se posaba un pájaro dorado de plumas luminosas» (198). El evidente simbolismo de este 
personaje supone un mensaje esperanzador para la nueva era. Del mismo modo, en el último párrafo de ¿En quién piensas...?, mientras la ciudad se derrumba a su alrededor, Yo Sánchez por fin reconoce que está enamorada — en la Ciudad de México de 2027, nadie ama_, y en seguida la naturaleza despierta a su alrededor: «en ese momento de destrucción masiva, de confusión general, de estremecimientos y estruendos, animados por las luces confundidas, todos los pájaros se pusieron a cantar, creyendo que era el alba» (1996: 273). Es decir: el amor bastará para desandar lo andado, para recuperar lo perdido.

Tanto Juan de Góngora como Yo Sánchez deben luchar, a lo largo de las novelas, en contra de las secuelas espirituales y anímicas de la contaminación. El primero llega a entender que «la pérdida gradual de suelo, de aire y de agua a su alrededor era la pérdida de su propio yo" (1993: 17), y va explorando esta relación entre el entorno y la intimidad en la pintura: «En los postreros días del mundo, voy a pintar el cuadro de mi vida, el cuadro de mí mismo, la vista del Valle de México. Pintar ese sueño abolido será mi última obra» (20). Señalé antes la preocupación de Aridjis por encontrar un nuevo lenguaje poético para los tiempos de la crisis ecológica; Juan de Góngora se enfrenta con el mismo dilema: «Por esa avenida venía un río, ¿cómo pintar ahora su ausencia, su cuerpo entubado, su carga de aguas negras?, ¿cómo pintar la desesperación de un río, el grito silencioso de la Naturaleza en agonía? - se preguntó, delante de su cuadro - ¿ ¿Cómo pintar la soledad del último conejo teporingo que se extingue en la falda de un volcán? " (164).

Para representar el silencio, se puede emprender — como en tantos poemas de Aridjis - un rescate (nostálgico) de las voces perdidas, pero también cabe la posibilidad de afinar el oído a los nuevos y disonantes ruidos del presente. El habla cotidiana de la gente, en el año 2027, ha cambiado: «Antes aquí las gentes platicaban de las tolvaneras de febrero, de los aguaceros de mayo, de la luna de octubre y de los fríos de diciembre, ahora hablan de las partículas suspendidas, de las inversiones térmicas y de las concentraciones de ozono. Un nuevo vocabulario ha entrado en su lenguaje cotidiano» (42). Este nuevo vocabulario se manifiesta también en la invasión de anglicismos y del spanglish. Tanto Juan de Góngora (133) como Yo Sánchez se escandalizan ante los letreros de las tiendas y los bares, «ejemplos lucientes de la contaminación del idioma»: 
Chicken Rápido, Century Veintiuno; Speak con Propiedad: Escuela de Spanglish; Latinoamerican Institute: Conserve la Tradition; Parking aquí; Pregnant? Nueve Meses sin Intereses; Café Mejor Lazy que Crazy; Jóvenes Encueradas, Mujeres sin Panties, No Cover; Golden Music. Dancing Topless A Toda Madre; Come: Rumberas Brasileñas; Regálate Esta Noche: Go Out Con Niña Cubana; Suisida, Goce el Último Sigh del Milenio. (1996: 235)

Sin embargo, aunque el lenguaje cambie y se contamine, hay también una extraña belleza en los paisajes de destrucción, heredera de la imaginería deslumbrante del apocalipsis bíblico. Como diría Yeats, a terrible beauty is born en la ciudad agonizante. Los sentidos se despiertan, fascinados por las «posibilidades estéticas de la contaminación» (28), y hay una curiosa paradoja en la repulsión y atracción sentidas por Yo Sánchez hacia estos nuevos paisajes: "Caminamos juntos bajo un cielo terriblemente sucio, no desprovisto de belleza, no carente de horror» (164).

Estas novelas de Aridjis caminan así por los mismos terrenos transitados en su poesía y ofrecen un escaparate privilegiado para expresar, mediante los personaje-portavoces, las inquietudes ecológicas y eco-literarias del autor. La promesa de una regeneración posterior a la catástrofe permite un desenlace optimista en La leyenda de los soles y ¿En quién piensas...? El tono de la poesía ecológica de Tiempo de ángeles y otros libros resulta, en cambio, más lírico y a la vez menos esperanzador. No debe sorprendernos: hay pocos panoramas, desde un punto de vista ecológico, menos esperanzadores que el que ofrece México en estos días. 


\section{CAPÍTULO 7. LA COMICIDAD ECOPOÉTICA DE NICANOR PARRA}

A comienzos de los años ochenta, después de publicar sus dos libros de Sermones y prédicas del Cristo de Elqui, Nicanor Parra (1914) empezó a encaminar su antipoesía hacia temas ecologistas. La hoja de Ecopoemas de 1982, y de 1983 tanto la caja de tarjetas postales Chistes par(r)a (des)orientar a la (policía) poesía como la antología Poesía política, contienen una buena muestra de una línea "ecopoética» que sigue hoy protagonizando gran parte de la producción de Parra, como se puede ver en Pichanga (1992), un disco del grupo de rock Congreso cuyas canciones se han hecho sobre los ecopoemas, así como en Mai Mai Peñi (Discurso de Guadalajara) de 1991 y en "Aunque no venga preparrado", un discurso que leyó en 1997, al recibir en Valdivia el Premio Luis Oyarzún por la Armonía con la Naturaleza.

Las preocupaciones ecologistas de otros poetas chilenos como Neruda o Teillier son fácilmente explicables: ambos recrean el espacio infantil como un lugar más o menos idealizado, integrado armónicamente en el mundo «natural» que el hablante maduro, instalado ya en la gran ciudad, intenta rescatar poéticamente en su obra. Cuando el espacio de la infancia se ve no sólo alejado temporalmente, sino además contaminado, deforestado y despoblado, la denuncia desde perspectivas ecologistas resulta más que previsible. Así ocurre tanto en Fin de mundo de Neruda como en Crónica del forastero de Teillier, ambos de 1968. El caso de Parra es diferente. Ni el espacio provinciano de la infancia ni la naturaleza tienen gran 
importancia en su obra y sus caminos hacia la ecología resultan, en este sentido, bastante anómalos.

\title{
La naturaleza en la poesía popular de Parra
}

La obra antipoética de Parra es eminentemente urbana en su perspectiva, su lenguaje y su contenido. Es curioso observar, sin embargo, cómo una imaginería procedente de la naturaleza forma parte integral de la poesía "popular» — de raíces campesinas pero con barniz surrealistade La cueca larga (1958):

\author{
Algunos toman por sed \\ Otros por olvidar deudas \\ Y yo por ver lagartijas \\ Y sapos en las estrellas. [...] \\ El vino puede tomarse \\ En lata, cristal o greda \\ Pero es mejor en copihue \\ En fucsia o en azucena. [...] \\ Si me dieran a elegir \\ Entre diamantes y perlas \\ Yo elegiría un racimo \\ De uvas blancas y negras. (1983: 53-54)
}

La oposición que estructura cada una de estas estrofas otorga una clara jerarquía a los elementos naturales: el vino se bebe mejor en una flor que en los recipientes artificiales; las uvas son superiores al esplendor cultural de las joyas, y las oníricas lagartijas y sapos son preferibles a las preocupaciones materiales de las deudas.

Fuera de la poesía popular de Parra — sus coplas, cuecas y villancicos - hay, en la estremecedora "Defensa de Violeta Parra», escrita en los años sesenta (un antipoema inhabitual por su gran emotividad positiva), un despliegue de referencias a la flora y fauna chilena que es insólito en la antipoesía, pero más que apropiado para esta celebración de la hermana menor, una poeta y cantante popular tan arraigada en el mundo campesino. Ella es un «árbol lleno de pájaros cantores» $\mathrm{y}$ va «liberando pájaros cau- 
tivos / entre las ramas» (161). El hablante enumera diversos pájaros chilenos - la bandurria, la tenca, el zorzal, la codorniza, la charagüilla y la gaviota de agua dulce - en un esfuerzo por abarcar y definir a Violeta, su «ave del paraíso terrenal» (162), o bien, su «Violeta de los Andes / Flor de la cordillera de la costa» que habla «la lengua de la tierra» (163).

\section{No hay vuelta atrás}

La primera sección de Poemas y antipoemas (1954) incluye varios poemas situados en un ambiente campesino, pero un tono irónico desactiva la nostalgia rutinaria de tanta poesía provinciana preocupada por volver como dirá, décadas más tarde, Teillier - a los «lares». Sin la ironía, «Defensa del árbol» —el primero de los monólogos dramáticos tan característicos en Parra- podría leerse como un poema ecologista: el hablante reprocha a un niño por lanzar piedras a un árbol. Sin embargo, la personificación excesivamente sentimental de los árboles ("Quien no hace nunca daño a nadie / no se merece tan mal trato. / Ya sea sauce pensativo / ya melancólico naranjo»), la patente desproporción entre la supuesta ofensa —el «gravísimo pecado» del niño - y la reprimenda ("Creo que no hay en todo Chile / niño tan malintencionado. / ¡Por qué te entregas a esa piedra / como a un puñal envenenado...!») y la pedantería del tono son signos de un razonamiento disparatado. Y al ser el hablante de poca confianza, se pone en duda la alabanza y defensa que él hace de «la gran persona que es el árbol»:

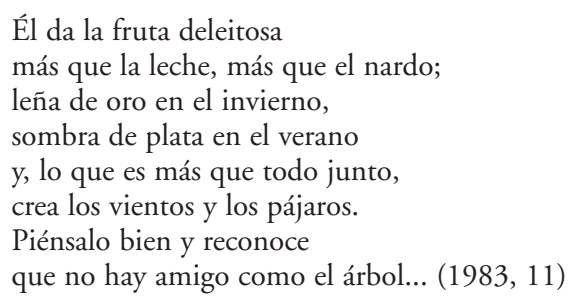

De la misma manera, en los poemas más celebrados de esta sección — «Hay un día feliz», "Es olvido» y «Se canta al mar»— la nostalgia está minada por un discurso hiperbólico, ridículo en su ingenuo sentimentalismo. El primero de estos textos cuenta una visita al pueblo natal en que «todo está como entonces»: «las golondrinas / en la torre más alta de la 
iglesia; / el caracol en el jardín, y el musgo / en las húmedas manos de las piedras» (14); pero la recuperación del pasado se hunde de nuevo en el absurdo cuando el hablante saluda "personalmente» a las ovejas que vuelven al establo, o cuando incorpora el tópico lírico del ruiseñor (un pájaro, recuérdese, inexistente en Chile) al espacio idílico, colocándolo además, de modo sin duda estrambótico, sobre la mesa del comedor: «Todo está igual, seguramente, / el vino y el ruiseñor encima de la mesa». El final del poema habla de la pérdida definitiva de los lares: todo es igual, «isólo que el tiempo lo ha borrado todo / como una blanca tempestad de arena!» (16). En realidad, la ironía que siente el lector, frente al desvarío discursivo del hablante, ya ha bastado en sí para borrarlo.

En la gran mayoría de sus antipoemas, Parra rehúye la idealización del espacio provinciano: los que celebran la armonía natural y los que buscan volver al paraíso perdido son, en esta poesía, personajes que deliran. Así, la visión idílica del Cristo de Elqui, el disparatado predicador que el antipoeta resucita como su alter ego en los años setenta, termina traicionándose a sí mismo cuando, al enumerar los lugares habitados por el Espíritu Santo, vira de las maravillas naturales a las creaciones de la modernidad:

La presencia del Espíritu Santo se percibe con toda nitidez en la mirada de un niño inocente en un capullo que está por abrir en un pájaro que se balancea sobre una rama

dificulto que alguien pueda poner en duda la presencia del Espíritu Santo en un pan recién sacado del horno en un vaso de agua cristalina en una ola que se estrella contra la roca

¡ciego de nacimiento tendría que ser!

hasta un ateo tiembla de emoción ante una sementera que se inclina bajo el peso de las espigas maduras ante un bello caballo de carrera ante un volkswagen último modelo. (1993: 221)

La celebración de un mundo «natural» impregnado en todas partes por el Espíritu Santo se acerca al animismo precristiano, pero Parra des- 
construye la descripción idílica al introducir elementos eminentemente "culturales»: el caballo de carrera — caballo desnaturalizado para satisfacer la avaricia humana - y el volkswagen último modelo — símbolo de la tecnología contaminadora-.

En cuanto a la vuelta al pasado, Parra rechaza la mitificación de la Edad de Oro tan frecuente en otros poetas. "Soliloquio del Individuo» acaba con un «no» rotundo — «Pero no: la vida no tiene sentido»—: una negación categórica a la posibilidad de encontrar la perfección futura o de regresar a un pasado mejor (1983: 52); y en Versos de salón, son seres desquiciados los que hablan de "dar la última mirada / en dirección del paraíso perdido" (75) o de comprar boletos para «recorrer los lugares sagrados» (74).

La vuelta atrás no funciona porque la antipoesía de Parra se ha hecho irremediablemente urbana; entrega la voz a hablantes que han sido atrapados por la gran ciudad y definitivamente desarraigados del campo. Poemas y antipoemas comienza con los versos "Una vez andando / por un parque inglés» (9), y a lo largo del libro los personajes irán desplazándose por este mismo paisaje urbano de parques y jardines, calles y cementerios. ${ }^{56}$ Por otro lado, resulta significativo que en un poema escrito a comienzos de los años setenta, "Moscas en la mierda», el hablante increpa "al señor —al turista— al revolucionario», preguntándoles si han visto alguna vez nubes de moscas en torno a "una plasta de mierda» y cuestionando, implícitamente, el valor de las «verdades» e intereses de los que no han experimentado, como él, la miseria en la infancia: "porque yo nací y me crié con las moscas / en una casa rodeada de mierda» (1985: 21).

La idealización de una infancia pobre — vivida entre la mierda - sería una falsificación y Parra no se permite los escapismos fáciles. Incluso cuando rememora a los profesores de la infancia, la alienación de los niños res-

56 En palabras de Federico Schopf: «El espacio de esta realidad —en los antipoemas- es abrumadoramente urbano. Las vastas extensiones del océano, los grandes ríos y volcanes, las playas desiertas, selvas australes, tormentas y lluvias, el cielo infinito, los planetas, los cuatro puntos cardinales que - según Huidobro- son tres: el sur y el norte, no existen - o casi no existen- en la antipoesía. La naturaleza aparece encerrada en el espacio urbano y, en general, reducido a "parques y jardines», es decir, a ornato municipal. Es una naturaleza cultivada, regulada — violentada - en su crecimiento y extensión por criterios de utilidad pública: es adorno, lugar de esparcimiento, dudoso pulmón de oxígeno» (2000: 159). 
pecto a su entorno natural es patente. No hay encuentros epifánicos como el de Neruda, relatado en sus memorias, con los pájaros o con ese coleóptero gigante que era el titán de los insectos de Chile; al contrario, lo único que interesaba a los alumnos eran los partidos de fútbol, y en sus clases los profesores - «enciclopedias rodantes» que los volvían locos con "preguntas que no venían al caso»- redujeron la naturaleza a una serie enajenante de datos que había que memorizar para los exámenes:

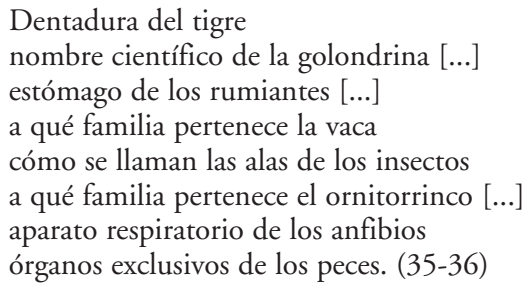

Por eso, los personajes antipoéticos, aunque anden perdidos y neurotizados por la ciudad, no sueñan con el regreso a la provincia. En «El túnel», el hablante vuelve a regañadientes al campo para cuidar a sus tías, obligado así a abandonar los placeres de la universidad y la vida galante. Pero el mundo natural pronto lo decepciona: "las horas de regocijo que pasé debajo de los árboles / tornáronse pronto en semanas de hastío / en meses de angustia [...] / tornáronse en años de ruina y de miseria / ¡en siglos de prisión vividos por mi alma [...]!» (1983: 36-37). No existe ni paz ni descanso en el campo; lejos del mundanal ruido, sólo hay hastío, angustia, ruina, miseria y encarcelamiento, atributos normalmente asociados desde una perspectiva bucólica- con la alienación urbana. Tanto el campo como la ciudad enajenan, pero al menos ésta seduce con sus ritmos galopantes, con su deslumbrante repertorio de estímulos.

No hay vuelta atrás para los personajes antipoéticos y crece su indiferencia hacia todo el mundo natural: «Un pequeño burgués es lo que soy / ¿Qué me importan a mí los arreboles!» (67). De hecho, la relación entre el hombre y la naturaleza no humana empieza a caracterizarse como un antagonismo violento. Las alusiones oníricas de "Sueños» son reveladoras en este sentido. Se come a los animales («sueño que estoy comiendo pejerreyes»), se pelea con ellos («sueño que estoy luchando con un perro») y se los mata («sueño que estoy matando una serpiente»), y la única imagen natural positiva en esta enumeración onírica resulta más bien equívoca: «Sueño 
con pajarillos voladores» (73). La redundancia del adjetivo voladores es sólo aparente, porque deja ver que este hablante está tan escindido del mundo natural que nunca ha visto "pajarillos» en libertad y hasta le sorprende el hecho de que vuelen. Como esos niños urbanos que conocen las vacas sólo como curiosas figuras de la pantalla, se siente infinitamente más cercano a los "platillos voladores» (que aparecen dos veces en Versos de salón) que al extraño ser alado que es un pájaro.

El espíritu anti-bucólico y anti-telúrico de Parra se reafirma en alusiones irónicas a la lírica tradicional. En uno de los "telegramas» de Obra gruesa (1969), el hablante dice que «Yo me arrodillo y beso la tierra / a la vez que me como un churrasco» (1983: 172), en una evidente degradación del gesto religioso y telúrico. Igualmente absurdo, se supone, es el "poeta lírico" de Hojas de Parra (1985), que "se arrodilla / ante un cerezo en flor / y comienza a rezar un padrenuestro» (1985: 88). Otro poema de este libro también apunta al anacronismo de la lírica tradicional:

\author{
SIETE \\ son los temas fundamentales de la poesía lírica \\ en primer lugar el pubis de la doncella \\ luego la luna llena que es el pubis del cielo \\ los bosquecillos abarrotados de pájaros \\ el crepúsculo que parece una tarjeta postal \\ el instrumento músico llamado violín \\ y la maravilla absoluta que es un racimo de uvas. (26)
}

Cada uno de estos siete temas - que son, huidobrianamente, seisdesnaturaliza los tópicos mediante la cursilería del lenguaje (el pubis de la doncella), analogías poco convincentes (la luna como el pubis del cielo), símiles o definiciones de escandalosa ingenuidad formulados desde una experiencia primordialmente urbana (el crepúsculo que parece una tarjeta postal, el instrumento llamado violín), la hipérbole (la maravilla absoluta de las uvas) y la adjetivación improbable en un mundo ecológicamente degradado (los bosquecillos abarrotados de pájaros). Por otro lado, la comunión con la naturaleza convence al antipoeta tan poco como la lírica, y ambas son el objeto de burlas crudas como la de «Coitus interruptus», una versión antipoética del mito de Leda y Júpiter: «ella que era aficionada a las aves / se enamoró locamente del cisne / y se le abrió de piernas al instante» (119). 
En los jardines y parques de la gran ciudad la naturaleza no humana no está, sin embargo, totalmente ausente: hay palomas, ratas, ratones y moscas; hay cipreses que obsesionan a los personajes (1983: 175) y aromos (mimosas) que a veces representan una efímera esperanza $(111 ; 122)$. Pero la ciudad es un espacio anti-natural, compuesto de "flores artificiales» (43) y de una atmósfera envenenada (46). Asimismo, aunque el protagonista no añore el campo, se representa a veces en imágenes de árboles que connotan una carencia profunda: «Pero yo soy un niño que llama a su madre detrás de las rocas, / soy un peregrino que hace saltar las piedras a la altura de su nariz, / un árbol que pide a gritos se le cubra de hojas» (32) $;{ }^{57} \mathrm{y}$ camina por un mundo en que «los árboles no son sino muebles que se agitan: / no son sino sillas y mesas en movimiento perpetuo» (31). Este contraste entre los bosques del campo y el paisaje urbano, donde los árboles sólo sobreviven como productos culturales, se repite otra vez en Poemas y antipoemas - "me abría paso a través de un bosque de sillas y mesas» (34) - y años después se recuperará en los ecopoemas. Pero más allá de estos pocos vestigios bucólicos, es evidente que le interesa a Parra representar un mundo desnaturalizado más que idealizar o lamentar una perdida experiencia infantil de lo natural. Al fin y al cabo, se trata de un antipoeta. No es ni Neruda, ni Mistral, ni Teillier.

\section{Contra la polarización:}

$\mathrm{Ni}$ socialista ni capitalista / sino todo lo contrario

Desde los comienzos de los años sesenta, Parra empezó a distanciarse de los grandes polos políticos e ideológicos de la guerra fría. En «Acta de independencia", un poema de 1963, un hablante al menos parcialmente autobiográfico (tiene la edad del autor) se declara "país independiente» en abierta rebelión contra la Iglesia Católica y el Comité Central (122). La renuncia de Parra a «definirse» ideológicamente en su poesía (y también en su vida) provocó reacciones furibundas en Chile, sobre todo después de los

57 «Qué podemos hacer, árbol sin hojas, / fuera de dar la última mirada / en dirección del paraíso perdido!» (1983: 75); «No me quejo de nada: tuve todo / Pero sin darme cuenta / como árbol que pierde una a una sus hojas / fuime quedando solo poco a poco» (110). 
eslóganes provocadores — pero tal vez previsores - de Artefactos (1972), que proponían alianzas inverosímiles como «Cuba sí / Yanquis también» y «La izquierda y la derecha unidas / jamás serán vencidas». Parra terminó políticamente aislado, primero bajo la Unidad Popular y más tarde bajo la dictadura pinochetista, pero esta vocación de disidente y el terco distanciamiento respecto a los extremos políticos se convertirán después en el fundamento de su pensamiento ecologista.

Jonathan Porritt, en su libro Seeing Green: The Politics of Ecology Explained, definió la postura verde como una oposición a todas las fuerzas políticas de la modernidad desarrollista:

La política de la Edad Industrial, de la izquierda, la derecha y el centro, es como una autopista de tres carriles, con vehículos distintos en los distintos carriles, pero todos encaminados en una misma dirección. Los verdes sienten que el error consiste en la dirección en sí más que en la elección de cualquiera de los carriles. Según nuestra percepción, la autopista del industrialismo conduce inevitablemente al abismo: de ahí nuestra decisión de abandonarla y buscar otra dirección totalmente diferente. (1984: 43)

Parra estaría de acuerdo, sin duda, con esta imagen de Porritt, aunque en un Chile escindido (durante los años setenta y ochenta) en dos grandes bloques políticos los carriles —contemplados desde el «balcón ecológico» del poeta- fueron sólo dos: los del socialismo y del capitalismo autoritario. Ilustra su visión al hablar de ambas ideologías como «la cara y la cruz de una moneda» o como hermanos siameses, "en el sentido que los dos andan buscando lo que se llama el paraíso en la tierra» mediante el desarrollo tecnológico. En efecto, «a estas alturas podemos decir que son igualmente depredadores. Los crímenes ecológicos del socialismo son tan graves o más que los propios crímenes del capitalismo» (Morales, 123).

En «Cristo de Elqui se defiende como gato de espaldas», Parra se dirige en esta misma línea, mediante su alter ego, a Volodia Teitelboim, hoy el flamante Premio Nacional de Literatura y en ese entonces presidente del Partido Comunista Chileno, en respuesta a las acusaciones — que llegaron a ser tan habituales como ridículas - sobre su hipotética colaboración con el régimen pinochetista: «Yo partidario de la Dictadura? / no me haga reír amigo Volodia» (1983a: 198). El Cristo-antipoeta afirma compartir las críticas de Teitelboim respecto al desempleo, la pobreza, la tortura y el autoritarismo, pero añade otro problema: el «record mundial en contaminación 
atmosférica / algo que a Ud. le tiene sin cuidado lo sé / como buen industrialista decimonónico». A continuación, enumera los principales problemas ambientales de Chile:

\author{
Y la ruina de bosques en el sur \\ y la extinción de las materias primas \\ y la erosión \\ y la muerte del mar \\ el DDT ya llegó a la tierra de los pingüinos \\ a las nieves eternas del Aconcagua \\ a las propias entrañas de las madres chilenas \\ hay que decir las cosas como son \\ estamos a un paso del Apocalipsis. (199-200)
}

El Cristo de Elqui acusa a Teitelboim por su complicidad en esta degradación ecológica y en la amenaza nuclear: "[Uds] saben que son capaces / de barrer el planeta 40 veces / con las armas atómicas que tienen / y continúan fabricando + // ¡una vergüenza que no tiene nombre!»; y lo critica también por su pensamiento maniqueísta, la implacable ceguera ecológica de la Guerra Fría: «Entretanto qué hacen Uds caramba / repetir al pie de la letra la bufonada capitalista» (200). Termina la carta-respuesta con una nueva alusión a la ideología comunista de Teitelboim — condenándola como obsoleta- y con una reescritura verde del artefacto, mencionado arriba (La izquierda y la derecha unidas / jamás serán vencidas), que tanto escandalizó en 1972:

lo siento mucho camarada Bolodia
no soy yo
son Uds. los que se quedaron atrás

SOCIALISTAS Y CAPITALISTAS DEL MUNDO UNÍOS antes que sea demasiado tarde. (201)

Es una equiparación que se repite en varios textos de la época: «Capitalismo / contaminación del hombre x el hombre / socialismo burrocrático / todo lo contrario» (150); o bien, «ni socialista ni capitalista / sino todo lo contrario: / ecologista» (1993: 369).

La parodia - o reformulación - de los eslóganes es constante en la ecopoesía: «Tercer y último llamado: / PEATONES DEL MUNDO 
UNÍOS» (1983a: 157). En la misma línea, Parra va aprovechando la forma textual de la fe de erratas para expresar el cambio que se propone dirigir desde el enfrentamiento político entre izquierdas y derechas hacia una denuncia ecologista: «dice: proletarios del mundo uníos / debe decir / peatones del mundo uníos» (155); «Dice: / proletarios / versus / burgueses / léase: / pacíficos peatones / versus / asesinos del volante» (152). También rebautiza palabras claves de la lucha política con el prefijo «eco»: ecompañero, ecompromiso, econstitución y ecoprogresista (149).

La caída del bloque soviético significó, para Parra, el fin definitivo de las grandes ideologías modernas y el triunfo sobre la sociedad teórica por la sociedad empírica, es decir, por "la ley de la selva» del capitalismo (Marras, 376). Ahora bien, esto no implica una actitud de laissez faire. Al contrario, intensifica sus ataques contra el desenfreno consumista. El consumismo es una "serpiente / que se traga a sí misma X la cola» (1983a: 154) y está a la raíz de todos los males ecológicos: «EXPLOSIÓN DEMOGRÁFICA / SAQUEO DE LA NATURALEZA / COLAPSO DEL MEDIO AMBIENTE / vicios de la sociedad de consumo / que no podemos seguir tolerando: / ¡hay que cambiarlo todo de raíz!» (154). Hay que cambiarlo todo, porque el capitalismo no conlleva ni armonía ni estabilidad: es más, «aquí no se respeta ni la ley de la selva». La metáfora no funciona; la violencia depredadora de la sociedad capitalista — su violación de las leyes naturales- carece del equilibrio cíclico aunque violento de los ecosistemas selváticos.

\section{¿Soluciones de parche o ecología utópica?}

Santiago de Chile es una de las ciudades más contaminadas del planeta y el asma que sufre Parra lo ha hecho doblemente sensible a los problemas de esta mega-ciudad, sobresaturada de coches, donde "ya no se puede respirar» (Zerán, 261). ${ }^{58} \mathrm{La}$ urgencia de la situación se trata en un ecopoema que deja en segundo plano incluso a los problemas apremiantes de la

58 El dato biográfico puede parecer innecesario. Y sin embargo, ¿no se siente la palpitación del asma, también "biográfica», en los ritmos poéticos de Gonzalo Rojas y en la prosa de Lezama Lima? 
pobreza: «Ya no pedimos pan / techo / ni abrigo / nos conformamos con un poco de aire / EXCELENCIA!» (1983a: 156); y también en una llamada hiperbólica al activismo violento: «Ecompañero peatón / haga patria: / mate un chofer al día / antes que los choferes lo maten a Ud. / el $90 \%$ del monóxido de carbono / que va a dar a nuestros pulmones / es exhalado x estos murciélagos» (160).

Parte de la denuncia ecopoética tiene que ver con la amenaza a la naturaleza no humana. Vuelve la imagen del bosque de sillas y mesas: «Recuerdos de infancia: / los árboles aún no tenían forma de muebles / y los pollos caminaban crudos x el paisaje» (163); y por primera vez desde su «Defensa de Violeta Parra», Parra procura establecer una relación estrecha con su entorno: "Qué será lo que dice / cuando mueve las hojas / El árbol dice algo / cuando mueve las hojas» (Carrasco, 233). Y en nombre de la poesía, reclama protección para los últimos cisnes de cuello negro, que hay que defender «a patadas / a combos / a lo que vaya: / la poesía nos dará las gracias» (1983a: 158).

En otras ocasiones, Parra reitera su inquietud por la explosión demográfica, «la madre de todos los males sociales o de casi todos los males sociales de la época», afirmando que la culpa corresponde a la Iglesia Católica (Marras, 383). Insiste, sin embargo, en una solución religiosa al problema:

\section{EXPLOSIÓN DEMOGRÁFICA: \\ Solución \\ Seguir el ejemplo del Padre Eterno \\ que tuvo sólo un hijo \\ O el de Nuestro Señor Jesucristo \\ que no tuvo ninguno. (Zerán, 267).}

O bien, en la distribución de condones tan anatemizada por la Iglesia: «un tanque vale alrededor de un millón de $\$ \$ \$$ / con esa plata se podrían comprar / 10.000.000 de condones / para los países del Tercer Mundo / que son los + afectados x la / Explosión Demográfica» (1983a: 153).

El discurso ecopoético se acerca en diversas ocasiones a lo apocalíptico o al catastrofismo. Al fin y al cabo, desde la perspectiva de Parra se trata realmente del «problema de la supervivencia» (Morales, 127). Varios poemas anticipan un fin venidero: "Porvenir / una bomba de tiempo» (1993: 360); «hurry up! / eternidades hay pero no muchas // el planeta ya no da 
para +» (368); o bien se sitúan en contextos posteriores a la destrucción global: «basta de profecías apocalípticas / ya sabemos QUEL MUNDO SEACABÓ» (1983a: 157); "Buenas noticias / la tierra se recupera en un millón / de años / Somos nosotros los que desaparecemos» (163).

Según Iván Carrasco, Parra ha emprendido una «verdadera cruzada» en Chile, y va por todas partes "predic[ando] su credo ecologista" como un «moderno gurú» (Carrasco, 234). En este sentido, ha nacido un contenido nítidamente utópico en la ecopoesía (235) que supone, en cierto modo, una superación de la antipoesía aunque en realidad, como sugiere Carrasco, el de Parra sigue siendo un discurso contestatario: en este caso, su ecopoesía sería una especie de anti-antipoesía. Lo cierto es, sin embargo, que Parra va y viene entre la visión utópica (Marras, 382), algo inverosímil en un poeta tan crítico y desmitificador, y el interés por las «soluciones de parche» (380). ${ }^{59}$ El problema puede ser, en el fondo, una cuestión de pragmatismo. La apropiación (ocultamente incrédula) de un discurso utópico, ¿no sirve, en términos pragmáticos, para promover una conciencia ecológica generalizada y formar así la base para intentar lograr la supervivencia del planeta?

Sabiéndose un personaje importante en el ecologismo chileno —él se autodefine como "uno de los fundadores, por lo menos "puertas adentro" del movimiento» (Zerán, 265)—, Parra ha adoptado dos lemas, de raíz utópica, que ha ido repitiendo en numerosos poemas y entrevistas a lo largo de las últimas décadas. El primero tiene ciertos ecos de la carta que Seattle, jefe de los indios Suquamish, dirigió en 1856 al gobernador de Washington cuando éste le ofreció comprar sus tierras. Seattle aceptó la oferta ("pues sabemos que, de no hacerlo, el hombre blanco vendrá con armas y tomará nuestra tierra»), pero a la vez mostró su incredulidad por la noción de compraventa de la tierra, porque «una cosa sabemos: que la Tierra no le pertenece al hombre. Es el hombre el que pertenece a la Tierra» (Boff, 1996a: 276). El texto de Parra, por su parte, dice: «el error consistió / en creer que la tierra era nuestra / cuando la verdad de las cosas / es que nosotros somos de la tierra» (1983a: 158; 1993: 367). Aquí sí existe ese regreso al pasado que fue siempre ridiculizado en la antipoesía, como

59 Lo que llama en otra parte, con cierto desprecio, la "ecología municipal» que se preocupa sólo por descontaminar el aire (Piña, 51). 
al final de «Soliloquio del individuo». La vida — siempre que sea una vida «ecológicamente sustentable»— ha vuelto a tener sentido.

El segundo de los lemas o eslóganes corresponde al comienzo de la llamada "Propuesta de Daimiel», el manifiesto o declaración de principios redactado por el marxista valenciano Josep Vicent Marqués en 1978 para la Federación del Movimiento Ecologista del Estado Español (Varillas, 87). Parra repite el texto palabra por palabra, pero vertiéndolo en la forma de versos:

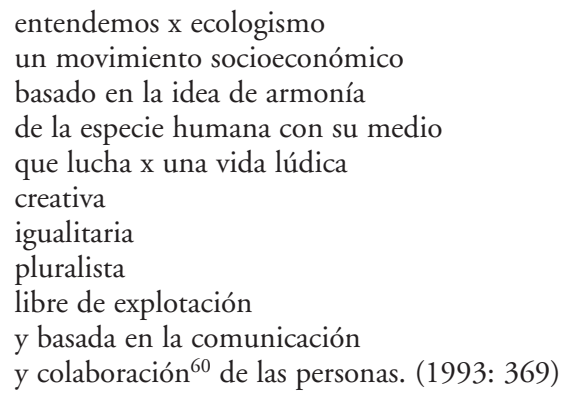

\section{Entre la agresión, el didactismo y la arenga política}

La obsesión parriana por conseguir una comunicación real con el lector es evidente desde los comienzos antipoéticos. Ya en «Advertencia al lector», el hablante termina con una amenaza: «iY yo entierro mis plumas en la cabeza de los señores lectores!» (1983: 28). Esta agresividad tiene que ver con el intento de borrar la separación entre arte y vida, y de abrir caminos para la poesía en la existencia cotidiana. Por eso, en "Manifiesto", Parra rechaza a los poetas burgueses que hablan con «signos cabalísticos» incomprensibles. Ahora bien, para ser un «poeta popular» en los años sesenta, ya no bastaba recrear las tradiciones de la poesía popular tradicional como en La cueca larga, sino que había que fundar la obra poética en «el lenguaje de todos los días» (154) y luego aprovechar las estrategias de los mass media - o cualquier otra estrategia - para llegar al lector. La agresividad parria-

60 «Cooperación» dice el texto de Marqués. 
na vuelve a aparecer cuando el poeta habla de sus intenciones en Artefactos (1972). Buscaba con ellos el mismo "pinchazo a la médula» que producen los grandes avisos luminosos cuando uno entra de noche en una ciudad moderna: «se trata de tocar puntos sensibles del lector con la punta de una aguja; de galvanizarlo de manera que el lector mueva un pie, mueva un dedo o gire la cabeza [...]; se trata de penetrar, de romper, de sacar al lector de su modorra y pincharlo» (Morales, 100-101).

Los Artefactos en sí, publicados como una caja de tarjetas postales, invitan a una participación activa del lector: éste, en principio, debería enviarlos a los amigos, permitiendo así que la poesía circule por el mundo e incida en la vida. En teoría, por lo menos. La segunda caja, Chistes par(r)a (des)orientar a la poesía (policía) [1983], vuelve al formato de Artefactos, pero aparte de su discurso abiertamente anti-Pinochetista, denuncia los peligros ecológicos y procura pinchar, penetrar, galvanizar y romper al lector, sacándolo de su modorra y convirtiéndolo en un ecologista comprometido. Con este mismo afán didáctico, Parra llegó a preparar un texto que pretendía ser el «Himno oficial del movimiento ecológico ("Los siete chanchitos")»:

1) Industrial y poeta capitalista naturalmente:

CHANCHO CON CHALECO

2) Agricultor sin inquietud ecológica qué duda cabe:

CHANCHO CON CHALECO

3) Ingeniero

se ríe de la ecología

prototipo del

CHANCHO CON CHALECO

4) Comunista marxista leninista

maoísta castrista jochiminista pinochetista refractario a la información ecológica lo siento mucho:

CHANCHO CON CHALECO

5) Sacerdote que fuma como murciélago sin la menor consideración X el prójimo 
que me perdone Su Santidad:

IMPERDONABLE

CHANCHO CON CHALECO

6) Profesor y conferenciante

excritor

para mal de sus pecados

autoexcluido del Frente Ecológico

no tiene vuelta:

CHANCHO CON CHALECO

7) AUTORIDAD CIVIL O MILITAR

indiferente a la realidad ecológica

debe ser desenmascarada públicamente

mono de nieve

CHANCHO CON CHALECO

nauseabundo chancho con chaleco. (1983a: 165-166)

Parra también aceptó un papel de activista más allá de su escritura. El reportaje "Auténticamente parriano", publicado en 1983 en la revista Hoy, transcribe un discurso suyo que fue pronunciado durante unas Jornadas Surrealistas en el Instituto Chileno-Francés de Cultura. Si el surrealismo, en sus orígenes, quiso espantar al burgués, cambiar la vida y borrar esa división — tan molesta para Parra - entre arte y vida, estas «jornadas surrealistas» organizadas por el establishment y celebradas en tiempos de la dictadura eran otra cosa, algo que hacía falta sabotear. Con esa intención la crítica ecologista, anti-eurocéntrica, anti-imperialista y anti-dictatorial de Parra funde las barreras en un delirio deliciosamente surrealista. Literatura, política y vida son una y la misma cosa:

Al poeta le pidieron que hablara. Y habló. Dijo entonces:

Qué bueno que la Francia inmortal-inmoral-inmortal, lo que sea, patrocine foros o forros hipotéticamente culturales en este último rincón del mundo. Como quien lanza serpentinas de colores a los mendigos del río Mapocho. Gracias en nombre de los afectados. Pero qué bueno sería también que el nunca bien ponderado gobierno francés se decidiera a cumplir sus compromisos nucleares y electorales con los ecologistas. En otras palabras, que ponga fin inmediato a la proliferación de armas nucleares en su territorio. Segundo: que desactive las ya existentes; y tres: que suspenda la venta sucia de armas atómicas o convencionales a los milicos del Tercer Mundo. NO al pragmatismo nuclear norteamericano. NO al formalismo nuclear ruso y $\mathrm{NO}$ también, caramba, al surrealismo nuclear francés. NO. NO. NO. NO. NO. NO. 
De pie, con el puño cerrado, mientras poco a poco todo el auditorio coreaba NO con él. Ahí terminaron las Jornadas Surrealistas. ("Auténticamente...», 13)

\section{Pichanga: la ecopoesía cantada}

La música permite una divulgación entre públicos a menudo cerrados para la poesía. No debería sorprender, por tanto, que Parra colaborara en Pichanga: Profecías a falta de ecuaciones (1992) con el grupo de rock Congreso, que puso música a algunos de sus ecopoemas como parte de una campaña internacional a favor de los Derechos del Niño.

El texto-canción «Recuerdos de infancia» habla de una infancia transcurrida en la miseria. Como siempre, los que peor sufren la degradación ecológica son los más pobres:

\section{No teníamos agua potable \\ Carecíamos de servicios higiénicos \\ Andábamos descalzos \\ Lo único que teníamos: piojos, baratas...}

Otro texto, el bolero «Días atrás un árbol me preguntó», presenta una visión elegiaca de un mundo natural diezmado. El hablante personifica tanto al árbol como a los pájaros, situándose lejos ahora de las ironías de los primeros antipoemas; pero el árbol ha quedado definitivamente huérfano de sus pájaros cantores (y cantautores). "Volverán de un momento al otro», dice el hablante. Pero no: «En este país ya no quedan pájaros / ni mariposas / ni chanchitos de tierra». La exterminación de las especies es imparable:

\footnotetext{
Días atrás un árbol me preguntó qué pasará con los señores pájaros hace tiempo que no los oigo cantar y yo le dije no se preocupe los pájaros cantautores andan en gira artística $\mathrm{X}$ ahí Volverán de un momento al otro

para que se deje de preguntas estúpidas Sabe mejor que nadie que en este país ya no quedan pájaros
} 
ni mariposas

ni chanchitos de tierra...

Volverán de un momento al otro. ${ }^{61}$

El propio yo padece la pérdida del entorno natural. Ya no sueña con árboles como antes, sino con partidos de fútbol y miserables programas televisivos. El panorama resulta desolador y la salida más que dudosa. En palabras de Parra: «la problemática está muy a la vista, pero la solucionática no se ve por ninguna parte» (Zerán, 266). En fin: hemos llegado a una situación de «desastre total».

Si en los últimos años, desde Santiago y los grandes centros culturales de Chile, se ha visto un movimiento inaudito de curiosidad por la cultura y la «oralitura» indígenas, Parra tituló su "Discurso de Guadalajara» Mai Mai Peñi — un saludo mapuche-, para reafirmar la idea de una «vuelta a las raíces» en su poesía. No se trata, insiste, de un indigenismo ingenuo: «La palabra mapuche la uso en forma metafórica para indicar el distrito propio, el distrito nativo en oposición al discurso ajeno o enajenado de origen europeo exclusivo, de origen americano, norteamericano exclusivo» (Zerán, 82). Evidentemente, esta defensa de lo local se perfila como la única posibilidad — desde una perspectiva ecologista — de frenar la depredación del capitalismo transnacional. En el poema-canción «No se diga que somos hispanoamericanos», Parra vuelve al problema onomástico — los cien nombres de América (Rojas Mix, 1991) — de siempre. Da la palabra al pueblo mapuche (mapu: tierra; che: gente) y a través de ella vuelve a insistir en la necesidad de una poesía autóctona: «No se diga que somos hispanoamericanos / Somos mapuches, gente de la tierra / Por favor, un poquitito de sentido común / Esto se llamó siempre Mapu / Con qué derecho cambiamos el nombre a las cosas».

Desde luego, los lemas tantas veces repetidos no podían faltar en Pichanga. «El error consistió» combina las palabras parafraseadas del jefe Seattle con la vieja imagen antipoética de los árboles transmutados en muebles:

El error consistió

en creer que la tierra era nuestra

Cuando la verdad de las cosas

61 Una versión ligeramente diferente se publicó en Zerán (1995: 67). 


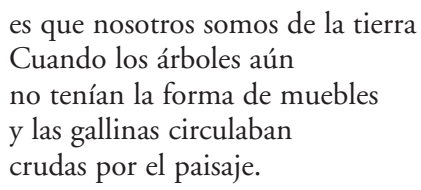

Y por último, sobre un fondo de niños ecologistas que increpan al abuelo fumador con la melodía de Frère Jacques, surge la voz del antipoeta, ahora ecopoeta, apropiándose de nuevo —en nombre de los «niños de Chile»— de las palabras de Josep Vicent Marqués:

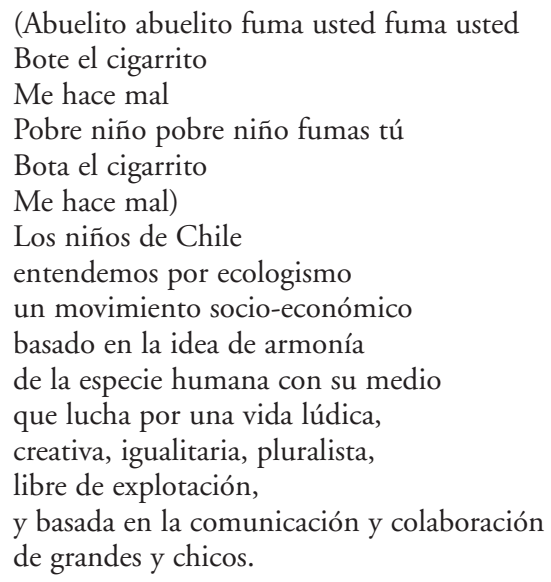

\section{La verdadera seriedad es cómica... y ecológica}

En su introducción a la antología Chistes par(r)a (des)orientar a la (policía) poesía, María Nieves Alonso y Gilberto Triviños niegan la percepción, compartida por gran parte de la crítica, de la esencial negatividad de la antipoesía y destacan «los elementos positivos, utópicos, proféticos de varios textos parrianos», entre ellos los ecopoemas (1989: 15). Aunque la negatividad exista a flor de texto en gran parte de la obra de Parra, creo que detrás de ella sí se puede rescatar un sentido más positivo: la ironía y la perspectiva crítica que subyacen bajo los ataques a la incomunicación humana y a la falta del sentido del humor, a la tendencia de dejarse doblegar por las vicisitudes de la vida y de pasar por el 
mundo con el ceño fruncido (¡cuántos personajes antipoéticos llevan este epíteto como estigma de su rendición frente a la vida!), muestran implícitamente - y por contraposición - el valor de la risa y de la comunicación. Los personajes antipoéticos se neurotizan y enloquecen porque no saben digerir los tropiezos y caídas de la vida, porque han perdido el contacto con el otro y la capacidad de reírse de sí mismos. En cambio, la risa - a pesar o más allá de los golpes en la vida, tan fuertes - es una apuesta por la vida y abre las puertas a la comunicación con los demás. Lo dijo Parra a Antonio Skármeta en 1968: "Yo pienso que el poeta debe ser un especialista en vías de comunicación. El humor facilita el contacto. Recuerde que es cuando se pierde el sentido del humor cuando se empiezan a sacar las pistolas» (Skármeta, 38). Por eso, como dijo en un discurso de 1962, la verdadera seriedad es cómica.

El ecocrítico norteamericano Joseph W. Meeker ha examinado la estrecha relación entre el género de la comedia y la ecología, en contraposición a la tragedia, que es parte y producto de esta cultura occidental que nos lleva, gracias a su exaltación del ser humano como una especie superior, al ecocidio. El héroe trágico es un ser excepcional, capaz de superar las limitaciones de su entorno y de luchar y sacrificarse en nombre del Bien, de Dios, de la Civilización o de la Patria. En una de las analogías biológicas que tanto gustan a Meeker, se equipara el comportamiento de este héroe (fruto de sus altos ideales) con el de especies pioneras como la rata, la anguila o la carpa, especies lo suficientemente duras, flexibles y agresivas para abandonar su entorno y (pese a los riesgos; acaso heroicamente) invadir, colonizar y radicalmente alterar ecosistemas ajenos. ${ }^{62}$

62 «Las especies ecológicamente pioneras, como los pioneros humanos, son criaturas capaces de vivir sin algunas de las necesidades normales experimentadas por otros de su género. Son individuos heroicos que construyen sus hogares donde nadie más quiere vivir, y sus vidas se encaminan hacia horizontes desafiantes y peligrosos. Arriesgan sus vidas para poder conquistar nuevos territorios, y su supervivencia depende de sus cualidades individuales de fuerza, agresividad y a menudo crueldad. Las especies pioneras son los solitarios del mundo natural, los héroes trágicos que se sacrifican para satisfacer misteriosos impulsos internos que sólo ellos son capaces de oír. Es posible que esto suene a antropomorfismo, pero no lo es. No estoy sugeriendo de ningún modo que las plantas y los animales posean cualidades humanas, sino que mucha elaborada filosofía acerca del comportamiento humano ha sido una simple racionalización de pautas de comportamiento natural relativamente comunes que se pueden encontrar en muchas especies de plantas y animales» (Joseph W. Meeker, «The Comic Mode», en Glotfelty, 161). 
Si la tragedia es producto de los sistemas metafísicos de la cultura occidental, estructurados en torno a las polarizaciones de siempre - el bien y el mal, civilización y barbarie, etc.-, Meeker afirma que la comedia, en cambio, es casi universal. No termina en el sacrificio y la muerte, sino en una vuelta a la normalidad, una reconciliación de los conflictos y la conservación del ecosistema. El héroe cómico es un «ser inferior» carente de grandes ideas, que refleja al ser humano más instintivo, más cercano a su ser animal, libre de ataduras metafísicas e interesado sobre todo por los placeres y necesidades básicas de la existencia, por la comida, el sexo y el juego; un ser muy poco dispuesto a arriesgarse la piel por una «idea». Dice Meeker: «más apropiados a nuestros días son los presupuestos relativamente modestos del espíritu cómico. El ser humano es parte de la naturaleza y sujeto a todas las limitaciones y fallos naturales». En la tragedia, el héroe o idealista procura salir de su ambiente natural y superarlo; en la comedia, se trata simplemente de salir del paso: "mientras que el héroe trágico sufre o muere por sus ideales, el héroe cómico sobrevive sin ellos». Puede ser débil, estúpido e indigno, pero se aferra a la vida y la vida continúa (157158). Por eso, en tiempos de crisis ecológica, la comedia es una esperanza: «en el actual dilema ambiental, la humanidad es como una especie pionera heroicamente enfrentada a las consecuencias de su propio comportamiento trágico, con una necesidad creciente de aprender de los héroes cómicos más estables de la naturaleza: los animales» (164).

En su libro más reciente sobre el tema, The Comedy of Survival: Literary Ecology and a Play Ethic, una libre reescritura de trabajos anteriores, Meeker ofrece dos paradigmas de su postura cuyas relaciones con Parra los hacen dignos de mención. Uno de ellos es Lisistrata, de Aristófanes («maestro absoluto» en la primera etapa antipoética de Parra: recuérdese el final de "Advertencia al lector»), una obra en que la guerra propagada por los hombres - héroes trágicos en potencia - en nombre de los altos ideales de la patria, la dignidad y el honor, termina cuando los personajes femeninos - heroínas cómicas: mujeres de Atenas, Esparta y de todas las partes de Grecia involucradas - declaran una huelga sexual hasta que se reestablezca la paz. Logran su propósito y la obra concluye ecológicamente, con una recuperación del equilibrio y el triunfo del ser instintivo, gobernado primordialmente por sus necesidades físicas. 
El segundo paradigma es Hamlet, una obra que ha fascinado a Parra en los últimos años (incluyó una versión del célebre «Ser o no ser» en Hojas de Parra). Poco antes de su muerte, Octavio Paz escribió: «Hamlet sigue poblando nuestros insomnios y cavilaciones. No ha sido nuestro santo ni nuestro demonio: ha sido nuestro espejo y, a veces, nuestro cómplice. Lo será más y más, sobre todo ahora que, después de la caída de las falsas certidumbres del socialismo totalitario y del derrumbe de las metahistorias, nos internamos en lo desconocido» (2000: 651). Para Meeker, este tipo de cavilación, tan propio de nuestra época incrédula, es fruto de la coexistencia en Hamlet (y en nosotros) de formas trágicas y cómicas de comportamiento: «Hamlet, como la mayoría de la gente del siglo XX, no está seguro si vive en un universo moral gobernado por valores metafísicos fijos o en un ambiente biológico que comparte con los demás animales». Por eso es incapaz de actuar, de cumplir el «deber» de la venganza exigido por el fantasma de su padre y exigido también, literariamente, por el género mismo de la tragedia, tan necesitado de la sangre derramada. Por eso Hamlet rehúye la violencia y se distrae en actos de "agresividad redirigida" —asemejándose así en su comportamiento, dice Meeker, a muchos animales cuando se enfrentan con otros de su especie- y en ataques verbales de una violencia meramente simbólica. Hasta el final de la obra Hamlet se porta como un héroe cómico, haciendo todo lo posible para evitar un combate mortal y mostrándose dispuesto a sufrir la humillación antes que la muerte. La "cultura" le dice que debe matar, pero algo en su instinto le dice que no: «En cada momento Hamlet intenta convertir actos en palabras, violencia en debate, asesinato en juego. Así invierte los procesos habituales de la acción trágica, que suele moverse de la palabra al hecho, del debate a la batalla, de las amenazas al asesinato. Es un maestro de la agresividad redirigida». Si al final sus intentos de permanecer un héroe cómico fracasan, es porque no le queda a Hamlet otra salida cuando Laertes lo traiciona, desencadenando la irremediable matanza final (1997: 37-49).

La visión de Meeker permite ver que el ecologismo de Parra tiene raíces muy anteriores a los ecopoemas de los años ochenta, porque estas cavilaciones hamletianas, espejo de nuestro desamparo ideológico tras la caída de las "falsas certidumbres» de la modernidad, han estado siempre presentes en la antipoesía y ofrecen una clave importante, me parece, para explicar de dónde realmente surge su vertiente ecopoética. Las falsas certidumbres han sido implacablemente desconstruidas por la antipoesía y ninguno de los hablantes, personajes o alter egos del antipoeta podría ser considera- 
do un ser superior, carne de tragedia. Al contrario, son seres acomplejados, desamparados y neuróticos, y en eso estriba lo que Eduardo Llanos ha llamado el «realismo psicológico» de Parra, algo ausente en sus grandes predecesores (Neruda, Huidobro, de Rokha) que no registraban sus contradicciones, sino que cultivaban «la cosmética consoladora de autorretratarse como un ser coherente». Como afirma Llanos, esta coherencia fue, en el fondo, una forma de enajenación (2001: 101-102).

Los personajes de Parra no son, en su gran mayoría, seres felices: los deberes religiosos y políticos siguen lacerándoles. Pero lo que me interesa aquí es la forma (siempre contradictoria, es decir, humana) en que ellos encarnan la inoperancia de esos deberes e ideologías, a veces superando o al menos sobrellevando su vacío ideológico y espiritual mediante la risa (aunque las heridas no les dejen de doler), o bien dejándose vencer y sometiéndose por tanto al repudio irónico del antipoeta que los observa desde detrás del texto, que acaso los compadece, pero que no los puede aceptar.

Un caso sintomático sería el poema «Padre nuestro» (1983: 125):

Padre nuestro que estás en el cielo

lleno de toda clase de problemas

con el ceño fruncido

como si fueras un hombre vulgar y corriente

no pienses más en nosotros.

Comprendemos que sufres

porque no puedes arreglar las cosas.

Sabemos que el Demonio no te deja tranquilo

desconstruyendo lo que tú construyes.

Él se ríe de ti

pero nosotros lloramos contigo:

no te preocupes de sus risas diabólicas.

Padre nuestro que estás donde estás

rodeado de ángeles desleales

sinceramente: no sufras más por nosotros

tienes que darte cuenta

de que los dioses no son infalibles

y que nosotros perdonamos todo.

No es cierto que éste sea un poema "tragicómico", como suelen decir los críticos: si el hablante comparte el llanto con el dios impotente del ceño frun- 
cido, es porque se ha dejado doblegar por la angustia metafísica; asimismo, el lector del poema que, después del primer impacto cómico, termina acongojado, también se ha dejado doblegar. El antipoeta, en cambio, se separa del hablante y se hermana con el demonio, participa en sus "risas diabólicas» y le ayuda a desconstruir lo que el dios construye. El antipoeta no puede simpatizar con la solemnidad desvertebrada: por eso, su poema no resulta tragicómico — es decir, la comedia no existe sólo para acentuar aun más lo trágico-, sino comitrágico, porque el sentimiento trágico que podría nacer del desamparo no se consolida; al contrario, sirve para hacer aun más vital la catarsis de la risa. Es la forma de salir del paso de la comicidad ecológica.

Muchos de los personajes antipoéticos carecen, en su soledad, de un sentido del humor, y es la risa del autor la que se escucha en sordina, entre bastidores, detrás o debajo de sus frenéticos, neuróticos monólogos, de su deambular enajenado por una ciudad en la que nadie les habla (así en poemas como "El peregrino», de Poemas y antipoemas). Pero hay otros personajes que muestran en carne propia la lucha entre risa y llanto, y que tal vez ayuden a encarnar el tipo de héroe cómico y ecológico que comentaba Meeker. Así en «Los dos compadres», cuando los personajes emprenden su viaje a Roma para ver al Papa, la comicidad los salva repetidamente de la metafísica y de la grave solemnidad que ésta acarrea. Más importantes que los grandes dilemas del más allá son la conversación entre amigos, la risa y los placeres cotidianos:

¡Y qué Santo Padre es ése!

Cómo que qué Santo Padre:

El Santo Padre de Roma.

¿El Santo Padre de Roma?

¡El Santo Padre de Roma!

No me haga reír compadre.

Ríase no más compadre.

¿No ve cómo se enojó?

Sabe una cosa compadre

Hablando se ven las cosas:

Lo invito a tomar un trago.

¿Verdad que murió en la cruz?

¡Claro que murió en la cruz!

¿Fumémonos un cigarro?

¡Fumémonos un cigarro! 


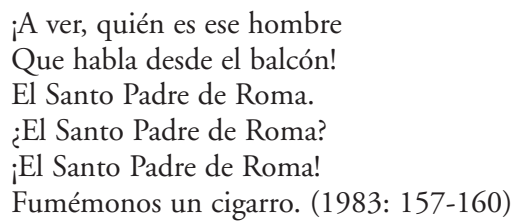

Los efectos humorísticos van más allá de la simple desacralización o banalización de ese cristianismo en crisis que hundió al hablante de «Padre nuestro». En la amistad y en la capacidad de disfrutar biológicamente de la vida, como diría Meeker, reside la posibilidad de combatir la angustia en nuestro mundo de las incredulidades postmodernas y de librarnos de la camisa de fuerza del cristianismo.

Otro ejemplo curioso es «Un hombre», también de Obra gruesa. En un ardiente elogio de este poema, el crítico y sacerdote José Miguel IbáñezLanglois ha escrito: «La condición humana es una breve anécdota. La transferencia de los fines, la fuga de los objetivos, lo que la vida hace con nosotros al margen de nosotros mismos entre risas y llantos vacíos, la alienación tragicómica de la voluntad... Es una parábola, no una alegoría»; y destaca, más allá del pesimismo del poema, «la piedad conmovida y reverencial por la condición humana» (1975: 258-259). ${ }^{63}$ Es cierto que el aturdimiento del protagonista, la forma aparentemente inhumana en que abandona, olvidándola, a su madre "gravemente enferma", en que se olvida de haber visto a su mujer con otro hombre y, por último, en que se olvida de buscar ayuda para su amiga atropellada, pueden ser signos de una alienación trágica o tragicómica. También pueden ser, sin embargo — si uno ve el poema no como un texto mimético, sino como parábola o alegoría (creo que da lo mismo)—, signos de la capacidad humana para adaptarse a las circunstancias y superar el sufrimiento, sobreviviendo y asumiendo una forma más cómica y más ecológica de la existencia. Estamos otra vez ante lo comitrágico. En la dialéctica de risa y llanto, tan común

63 Álvaro Salvador, por su parte, interpreta el poema como un paradigma de la postmodernidad según la interpretación de Fredric Jameson: «El poema queda reducido a una serie de meros presentes carentes de toda relación en el tiempo, transmitidos con una rara “intensidad", llena de cargas de afectividad, esporádicas y no relacionadas. El carácter temporal de la narración clásica o moderna desaparece o se diluye ostensiblemente. Es lo que podríamos llamar un ejercicio de discontinuidades» (1993: 269). 
en Parra, triunfa la risa. Llora el protagonista por su madre enferma y su mujer infiel, pero la conversación y las risas con el amigo de juventud, luego el baile y las risas con la muchacha joven y, por último, la invitación a cenar con el amigo pesan más que el llanto:

Se sienta a comer

Bebe como un condenado

Ríe

Lo hacen recitar

Recita

Se queda dormido debajo de un escritorio. (1983: 180)

Curiosamente, la insensibilidad y la inhumanidad de estos reiterados olvidos, que nos llegan a horrorizar - y el horror se percibe incluso en la voz hasta ahora conscientemente "objetiva» del hablante- constituye en realidad lo humano del personaje. Porque éste, fiel a su humanidad más esencial (y no metafísica), no ha sido doblegado por la desgracia: el contacto humano y los placeres biológicos y compartidos — la comida, la bebida, el baile, la risa (¿por qué tiene que ser, como quiere Ibáñez-Langlois, una risa «vacía»?) y hasta la lectura de poemas - le permiten sobrellevar el dolor y aferrarse a la vida. "Bebe como un condenado", dice el hablante del texto. Pero ojo: a diferencia de los héroes trágicos, capaces de dejarse morir del dolor o matar por honor a la esposa infiel y a su amante, éste es un héroe o antihéroe cómico. Un condenado a la supervivencia. 


\section{NOTA FINAL}

Este libro es fruto del proyecto En defensa del planeta: ecología en la poesía hispánica, auspiciado por una Beca de Investigación de la Fundación Caja de Madrid y dirigido por el Dr. Luis Sainz de Medrano.

Primeras versiones de algunos capítulos o fragmentos de capítulos del libro han sido publicadas con anterioridad en las siguientes publicaciones:

\section{Capítulo 1:}

«Ecocrítica, ecocriticism, ¿otra moda más en las aulas?». Babab. Marzo de 2001: www.babab.com/no07/ecocritica.htm.

«Sobre el mestizaje de los orígenes o una defensa de la edad de oro». Salamandra. Intervención surrealista, imaginación insurgente, critica de la vida cotidiana 11-12, Madrid, 2001-2002: 154-157.

\section{Capítulo 2:}

"Criaturas del desarraigo, o en busca de los lugares perdidos: alienación y ecología en la poesía hispanoamericana». América Latina Hoy 30, Salamanca, 2002: 43-77.

\section{Capítulo 3:}

«Del pájaro simbólico al pájaro real: descubrimiento del mundo y advenimiento de la ecología en la poesía de Neruda». En Néstor Ponce (coord.), Lectures d'une oeuvre: "Residencia en la tierra" / "Canto general» de Pablo Neruda, París, Éditions du Temps, 2000: 44-60. 


\section{Capítulo 5:}

«Los indicios del fin: la poesía ecologista de José Emilio Pacheco». Literatura y Lingüistica 13, Santiago de Chile, 2000-2001: 125-144.

\section{Capítulo 7:}

«Raíces y práctica de la ecopoesía en Nicanor Parra: de Poemas y antipoemas a Pichanga. En Ángel Esteban, Gracia Morales y Álvaro Salvador (eds.), Literatura y música popular en Hispanoamérica, Granada, Método Ediciones, 2002: 355-365.

«¿Por qué ecopoesía?». En VV.AA., Ciclo Homenaje en torno a la figura y obra de Nicanor Parra. Coloquio Internacional de escritores y académicos, Santiago de Chile, División de Cultura/Ministerio de Educación, 2002: 59-73. 


\section{BIBLIOGRAFÍA}

Aguirre, Margarita, Pablo Neruda Héctor Eandi, Ed. Sudamericana, Buenos Aires, 1975.

Alameda Ospina, Raúl, «Cambiamos o desaparecemos», en VV.AA., Biodiversidad, recursos naturales en la guerra del siglo XXI, Disloque, Santafé de Bogotá, 1998, 89-98.

Alonso, Amado, Poesía y Estilo de Pablo Neruda, Edhasa, Barcelona, 1979.

ARAújo, Joaquín, XXI: Siglo de la ecología, Espasa, Madrid, 1996.

ARIDJIS, Homero, Playa nudista / El último Adán, Argos Vergara, Barcelona, 1982.

- La leyenda de los soles, FCE, México, 1993.

- Antología poética (1960-1994), FCE, México, 1994.

— ¿En quién piensas cuando haces el amor?, Alfaguara, México, 1996.

- Tiempo de ángeles, FCE, México, 1997.

- Ojos de otro mirar, El Tucán de Virginia, México, 1998.

- La montaña de las mariposas, Alfaguara, México, 2000.

— «El milenio del Sol», Revista de México, 588-589: 8-10, $2000 a$.

"Auténticamente Parriano», Hoy, Santiago, 6-12 de julio: 13. 1983.

BATE, Jonathan, The Song of the Earth, Picador, Londres, 2000.

Baudelaire, Charles, Les Fleurs du Mal, Presses Pocket, París, 1981.

BELlO, Andrés, Silvas americanas y otros poemas, Ramón Sopena, Barcelona, 1978.

Bernabé Pajares, Alberto, (intro., trad. y notas), Himnos Homéricos. La "Batracomiomaquia», Gredos, Madrid, 1988.

Berman, Marshall, All that is Solid Melts into Air: The Experience of Modernity, Verso, Londres, 1983.

Blake, William, Selected Poetry, Oxford University Press, Oxford, 1994.

Blanco, José Joaquín, «Sonámbulos del progreso», en Pablo Pascual y José Woldenborg, coord., Desarrollo, desigualdad y medio ambiente, Cal y Arena, México, 1994, 389-403. 
Bloom, Harold, The Western Canon: The Books and Schools of the Ages, Papermac, Londres, 1995.

Boff, Leonardo, "La ecología como nuevo espacio de lo sagrado», Fernando Mires et al., Ecología solidaria, Trotta, Barcelona, 1996, 93-103.

- Ecología: grito de la tierra, grito de los pobres, Trotta, Madrid, 1996a.

Bowler, Peter J., Historia Fontana de las ciencias ambientales, FCE, México, 1998.

Bradley, John, ed., Atomic Ghost. Poets Respond to the Nuclear Age, Coffee House Press, Minneapolis, 1995.

Brailovsky, A.E., y Dina Foguelman, Memoria verde: historia ecológica, Sudamericana, Buenos Aires, 1990.

Buell, Lawrence, The Environmental Imagination: Thoreau, Nature Writing, and the Formation of American Culture, The Belknap Press, Cambridge, MA., 1995.

- Writing for an Endangered World: Literature, Culture, and Environment in the U.S. and Beyond, The Belknap Press of Harvard University Press, Cambridge, MA., y Londres, 2001.

CALINESCu, Matei, Cinco caras de la modernidad: modernismo, vanguardia, decadencia, kitsch, postmodernismo, Tecnos, Madrid, 1991.

CARDENAL, Ernesto, La hora cero y otros poemas, El Bardo, Barcelona, 1971.

- Oráculo sobre Managua, Ediciones Carlos Lohlé, Buenos Aires/México, 1973.

- Vuelos de victoria, Visor, Madrid, 1984.

- Cántico cósmico, Trotta, 2. ${ }^{a}$ ed., Madrid, 1993.

CARRANZA, María Mercedes, El canto de las moscas (versión de los acontecimientos), Nuevas Ediciones de Bolsillo, Barcelona, 2001.

CARRASCO, Iván, Nicanor Parra: La escritura antipoética, Universitaria, Santiago, 1990.

Carson, Rachel, Silent Spring, Penguin Classics, Londres, 2000.

CASAL, Julián del, Poesías completas y pequeños poemas en prosa en orden cronológico, Ediciones Universal, Miami, 1993.

Chinuailaf, Elicura, De sueños azules y contrasueños, Huerga y Fierro, Madrid, 2002.

ClaUde, Marcel, Una vez más la miseria: ¿Es Chile un país sustentable?, LOM Ediciones, Santiago, 1997.

Coleridge, Samuel Taylor, A Coleridge Selection, MacMillan, London, 1963.

Colón, Cristóbal, Diario de Colón, prólogo de Gregorio Marañón, Ediciones Cultura Hispánica, Madrid, 1968.

Costa, René de, ed., Vicente Huidobro y el creacionismo, Taurus, Madrid, 1975.

Crosby, Alfred W., Imperialismo ecológico: la expansión biológica de Europa, 9001900, Grijalbo, Barcelona, 1988. 
Cuadra, Pablo Antonio, Poesía. Selección 1929-1962, Ediciones Cultura Hispánica, Madrid, 1964.

Darío, Rubén, Poesías completas, FCE, México, 1952.

Daydi-Tolson, Santiago, "Las patrias de Gabriela Mistral», Revista Chilena de Literatura 27-28, 1986, 197-202.

Debicki, Andrew, Poetas hispanoamericanos contemporáneos: punto de vista, perspectiva, experiencia, Gredos, Madrid, 1976.

Deitering, Cynthia, «The Postnatural Novel: Toxic Consciousness in Fiction of the 1980s», en Cheryll Glotfelty y Harold Fromm, eds., The Ecocriticism Reader: Landmarks in Literary Ecology, The University of Georgia Press, Atenas y Londres, 1996, 196-203.

Devall, Bill, y George Sessions, Deep Ecology: Living as if Nature Mattered, Peregrine Smith, Salt Lake City, 1985.

Downing, Christine, La diosa: imágenes mitológicas de lo femenino, Kairos, Barcelona, 1999.

ELDER, John, Imagining the Earth: Poetry and the Vision of Nature, 2. a edición, University of Georgia Press, Atenas, 1996.

ELIADE, Mircea, Lo sagrado y lo profano, Labor, Barcelona, 1992.

Elmore, Peter, «Zoología fantástica y doméstica: el bestiario poético de Antonio Cisneros», Hispanic Journal, 19, 2, 1998, 253-261.

ErCilla, Alonso de, La araucana, Cátedra, Madrid, 1993.

Ezcurra, Exequial et al., The Basin of Mexico: Critical Environmental Issues and Sustainability, United Nations University, Nueva York, 1999.

FERRY, Luc, El nuevo orden ecológico: el árbol, el animal y el hombre, Tusquets, Barcelona, 1994.

FisCHER, María Luisa, Historia y texto poético: la poesía de Antonio Cisneros, José E. Pacheco y Enrique Lihn, Lar, Concepción, 1998, 69-124.

FORNS-BROGGI, Roberto, «¿Cuáles son los dones que la naturaleza regala a la poesía latinoamericana?», Hispanic Journal, 19, 2, 1998, 209-238.

FOUCAULT, Michel, Las palabras y las cosas: una arqueología de las ciencias humanas, Siglo XXI, 21. a ed., México, 1991.

GALEANO, Eduardo, "La ecología en el marco de la impunidad», en Fernando Mires et al., Ecología solidaria, Trotta/Fundació Alfonso Comín, Madrid, 1996, 55-62.

GIFFord, Terry, Green Voices: Understanding Contemporary Nature Poetry, Manchester University Press, Manchester, 1995.

Glotfelty, Cheryll, y Harold fromm, eds., The Ecocriticism Reader: Landmarks in Literary Ecology, The University of Georgia Press, Atenas y Londres, 1996.

HART, Stephen M., "Vallejo's "King of Swords": The Portrayal of Nature in "El libro de la Naturaleza" ", Hispanic Journal 19, 2, 263-270. 
Hedstrom, Ingemar, y José Francisco GÓMeZ H., El desafío ecológico en América Latina, El Buho, Bogotá, 1991.

HISPANIC JOURNAL, número especial sobre «Ecology in Latin American and Caribbean Literature», Indiana University of Pennsylvania, 19, 2, 1998.

Huidobro, Vicente, Obras completas, Zig-Zag, Tomo I, Santiago de Chile, 1964. Huysmans, Joris-Karl, Contra Natura, 2. a edición, Tusquets, Barcelona, 1997. IbáÑ̃ez Langlois, José Miguel, Poesía chilena e hispanoamericana actual, Nascimento, Santiago, 1975.

IXQUIC, Revista Hispánica Internacional de Análisis y Creación, número dedicado a la literatura ecológica, Australia, 2, Melbourne, 2000.

Jameson, Fredric, Postmodernism, or, The Cultural Logic of Late Capitalism, Verso, Londres, 1991.

Joseph, Lawrence E., Gaia: la tierra viviente, Cuatro Vientos, Santiago, 1992.

Kroeber, Karl, Ecological Literary Criticism: Romantic Imagining and the Biology of the Mind, Columbia University Press, Nueva York, 1994.

LARRAIN, Ana María, «Nicanor Parra: Yo prefiero seguir buscándole el cuesco a la breva", Revista de Libros (El Mercurio), 14, julio: 1, 1991, 4-5.

LARREA, Juan, «Vicente Huidobro en vanguardia», Revista Iberoamericana, 106107, 1979, 213-273.

LATORRE, Mariano, La literatura de Chile, Instituto de Cultura Latinoamericana, Buenos Aires, 1941.

LeEming, David, y Jake Page, Goddess: Myths of the Female Divine, Oxford University Press, Oxford, 1994.

LiENLAF, Leonel, Se ha despertado el ave de mi corazón, Universitaria, Santiago, 1989

LiHn, Enrique, Escrito en Cuba, Ediciones Era, México, 1969.

Llanos Melussa, Eduardo, "Antipoesía y ecología psíquica», Praxis. Revista de Psicología y Ciencias Humanas, 3: 3, Santiago, 2001, 97-109.

- Antología presunta: 1976-2002, FCE, Santiago, 2003.

LOVELOCK, James, Gaia, una nueva visión de la vida sobre la tierra, Orbis, Barcelona, 1985.

- Las edades de Gaia: una biografia de nuestro planeta vivo, Tusquets, Barcelona, 1995.

MARRAS, Sergio, América Latina (marca registrada), Universitaria, Santiago, 1992.

MARTA SOSA, Joaquín, La ecología literaria como responsabilidad del escritor, Equinoccio, Caracas, 1989.

MatTHews, Caitlin, Las Diosas: al reencuentro con la divina femineidad, EDAF, Madrid, 1992.

Meadows, Dennis, et al., The Limits to Growth, Pan Books, Londres, 1983. 
MeEker, Joseph W., The Comedy of Survival: Literary Ecology and a Play Ethic, University of Arizona Press, Tucson, 1997.

Melville, Elinor G.K., A Plague of Sheep: Environmental Consequences of the Conquest of Mexico, Cambridge University Press, Cambridge, 1994.

Merchant, Carolyn, The Death of Nature: Women, Ecology and the Scientific Revolution, Harper Collins, San Francisco, 1990.

Mies, Maria y Vandana SHIVA, Ecofeminismo: Teoría, crítica y perspectivas, Icaria, Barcelona, 1993.

Mires, Fernando, El discurso de la naturaleza: ecología y política en America Latina, Departamento Ecuménico de Investigaciones, San José (Costa Rica), 1990.

- «La nueva ecológica: el sentido político de la ecología en América Latina», en Mires et al., Ecología solidaria, Trotta/Fundació Alfonso Comín, Madrid, 1996, 13-37.

Mistral, Gabriela, Lecturas para mujeres, Porrúa, México, 1976.

- Recados para América, Edición de Mario Céspedes G., Santiago, EPESA, 1978.

- Desolación, Ternura, Tala, Lagar, Porrúa, México, 1986.

- Lagar II, Dirección de Bibliotecas, Archivos y Museos, Santiago, 1991.

- Poesías completas, Andrés Bello, Barcelona, 2001.

Molina NúNEZ, Julio, y Juan Agustín ARAYA, eds., Selva lírica, Soc. Imp. y Lit. Universo (hay edición facsimilar en LOM Ediciones, 1997), Santiago, 1917.

Montes, Hugo, y Mario Rodríguez, Nicanor Parra y la poesía de lo cotidiano, Editorial del Pacífico, Santiago, 1970.

Morales, Leonidas, Conversaciones con Nicanor Parra, Universitaria, Santiago, 1990.

MuÑOZ PRADAS, Francesc, «Explosión demográfica y crisis ecológica», en Fernando Mires et al., Ecología solidaria, Trotta/Fundació Alfonso Comín, Madrid, 1996, 63-77.

MurPhy, Patrick D., Literature, Nature, and Other: Ecofeminist Critiques, State University of New York Press, Nueva York, 1995.

Neruda, Pablo, Confieso que he vivido: memorias, 10. ${ }^{\text {a }}$ edición, Seix Barral, Barcelona, 1988.

- Obras completas I. De "Crepusculario" a "Las uvas y el viento", 1923-1954, Galaxia Gutenberg/Círculo de Lectores, Barcelona, 1999.

— Obras completas III: De "Arte de pájaros» a "El mar y las campanas", 1966-1973, Galaxia Gutenberg/Círculo de Lectores, Barcelona, 2000.

- Obras completas IV: Nerudiana dispersa I, 1915-1964, Galaxia Gutenberg/Círculo de Lectores, Barcelona, 2001.

Ortiz Monasterio, Fernando, et al., Tierra profanada: historia ambiental de México, Instituto Nacional de Antropología e Historia, México, 1987. 
Oyarzún, Luis, "Gabriela Mistral en su poesía», Anales de la Universidad de Chile, 106, 1957, 11-14.

PACHECO, José Emilio, «Nota sobre la otra vanguardia», Revista Iberoamericana, 106-107, 1979, 327-334.

- Los trabajos del mar, Cátedra, Madrid, 1983.

- Tarde o temprano, 2. a edición, FCE, México, 1986.

- Ciudad de la memoria (Poemas 1986-1989), Era, México, 1989.

- El silencio de la luna (poemas 1985-1993), Era/Casa de Poesía Silva, México, 1996.

PAREDES, Jorge, y Benjamín MCLEAN, «Hacia una tipología de la literatura ecológica en español», Ixquic, Revista Hispánica Internacional de Análisis y Creación, 2, 2000, 1-37.

PARKINSON ZAMORA, Lois, Narrar el apocalipsis: la visión histórica en la literatura estadounidense y latinoamericana contemporánea, FCE, México, 1994.

ParRA, Nicanor, Artefactos, Ediciones Nueva Universidad, Santiago, 1972.

- Obra gruesa, Andrés Bello, Santiago, 1983.

- Poesía política, Bruguera, Santiago, 1983a.

- Chistes par(r)a (des)orientar a la (policía) poesía, Galería Época, Santiago, $1983 b$.

- Chistes par(r)a desorienta a la (policía) poesía, edición de María Nieves Alonso y Gilberto Triviños, Visor, Madrid, 1989.

- Pichanga: Profecías a falta de ecuaciones (disco grabado por el grupo de rock Congreso), Alerce, Santiago, 1992.

- Poemas para combatir la calvicie: muestra de antipoesía, FCE, México, 1993.

— "Qué sería de este país sin Vicente Huidobro», La Época, 12 de septiembre, 78B, Santiago de Chile, 1993a.

- "Aunque no venga preparrado», en Páginas en blanco, Ediciones Universidad de Salamanca, Salamanca, 2001, 409-436.

Pastor, Beatriz, Discurso narrativo de la Conquista de América, Casa de las Américas, La Habana, 1983.

PaZ, Octavio, Obras completas I, Galaxia Gutenberg/Círculo de Lectores, 2. a edición, Barcelona, 1999.

-Obras completas II, Galaxia Gutenberg/Círculo de Lectores, 2. a edición, Barcelona, 2000.

PeSSOA, Fernando, Poemas escolhidos, 2. ${ }^{a}$ edición, Biblioteca Ulisseia de Autores Portugueses, Lisboa, 1988.

Pinto Villarroel, Patricia, «La mujer en Poema de Chile: entre el decir y el hacer de Gabriela», Acta Literaria, 14, 1989, 11-24.

PIÑA, Juan Andrés, «La antipoesía no es un juego de salón», en Conversaciones con la poesía chilena, Pehuén, Santiago, 1990, 13-51. 
Pogue Harrison, Robert, Forests. The Shadow of Civilization, The University of Chicago Press, Londres, 1993.

PORRITT, Jonathan, Seeing Green: The Politics of Ecology Explained, Blackwell, Oxford, 1984.

Proust, Marcel, Por el camino de Swann. En busca del tiempo perdido, Unidad Editorial, Madrid, 1999.

QUiroga MARTínez, Rayen, ed., El tigre sin selva: consecuencias ambientales de la transformación económica de Chile: 1974-1993, Instituto de Ecología Política, Santiago, 1994.

Riechmann, Jorge, Ética y ecología: dos meditaciones, documentos de Trabajo de la Fundación 1. ${ }^{\circ}$ de Mayo, Madrid, 1997.

- ed., Necesitar, desear, vivir: sobre necesidades, desarrollo humano, crecimiento económico y sustentabilidad, Libros de la Catarata, Madrid, 1998.

- Todo tiene un límite: ecología y transformación social, Debate, Madrid, 2001.

— «La ilusión del origen», Salamandra. Intervención surrealista-Imaginación insurgente-Crítica de la vida cotidiana, Madrid, 11-12, 2001a, 148-153.

RiLKE, Rainer Maria, Cartas a un joven poeta, Alianza, Madrid, 1999.

Rivera Villegas, Carmen M., "Voces ecológicas en la poesía puertorriqueña», Hispanic Journal 19, 2, 1998, 239-252.

Rojas Mix, Miguel, Los cien nombres de América: Eso que descubrió Colón, Lumen, Barcelona, 1991.

Romero Lankao, Patricia, «Ciudad de México: Problemas socioambientales en la gestión del agua», en Antonio Yúnez-Naude, Medio ambiente: problemas y soluciones, El Colegio de México, México, 1994, 235-270.

SAINZ, Enrique, "Fin de siglo», Casa de las Américas 196, 1988, 147-149.

Sainz de Medrano, Luis, Pablo Neruda: cinco ensayos, Bulzoni, Milán, 1996.

SALVADOR, Álvaro, «La antipoesía entre el neovanguardismo y la posmodernidad», en Luis Sainz de Medrano (ed.), Las vanguardias tardias en la poesía hispanoamericana, Bulzoni, Roma, 1993, 259-270.

SCHOPF, Federico, De la vanguardia a la antipoesía, LOM, Santiago, 2000.

Scigaj, Leonard M., Sustainable Poetry: Four American Ecopoets (A.R. Ammons, Wendell Berry, W.S.Merwin, Gary Snyder), University Press of Kentucky, Lexington, 1999.

Sepúlveda Llanos, Fidel, "Gabriela Mistral: una ecología estética», Aisthesis, Santiago, 28, 1995, 60-71.

ShOWALTER, Elaine, ed., The New Feminist Criticism: Essays on Women, Literature and Theory, Pantheon, Nueva York, 1985.

SiCARD, Alain, El pensamiento poético de Pablo Neruda, Gredos, Madrid, 1981. 
SkÁrmetA, Antonio, «El apogeo del antipoeta», Ercilla, Santiago, 14 de agosto, 1968, 34-39.

Sola, María Magdalena, Poesía y política en Pablo Neruda (análisis del "Canto general»), Ed. Universitaria (Universidad de Puerto Rico), Río Piedras, 1980. SuCRE, Guillermo, La máscara, la transparencia, Monte Ávila, Caracas, 1975.

TAPIA, F., y M. TOHARIA, Medio ambiente: ;alerta verde? (Gestión ambiental contra desarrollo insostenible), Acento, Madrid, 1995.

Teillier, Jorge, Crónica del forastero, Imprenta Arancibia Hnos., Santiago de Chile, 1968.

- Prosas, Editorial Sudamericana, Santiago de Chile, 1999.

- El árbol de la memoria. Antología poética, Huerga y Fierro, Madrid, 2000.

Thomas, Edward, Selected Poems, Faber y Faber, Londres, 1964.

Tournier, Michel, El espejo de las ideas, El Acantilado, Barcelona, 2000.

Unamuno, Miguel de, Antología poética, Espasa-Calpe, Madrid, 1992.

VARILLAS, Beningo, y Humberto DA CRUZ, Para una historia del movimiento ecologista en España, Miraguano, Madrid, 1981.

VelázQUeZ, Margarita, coord., Género y ambiente en Latinoamérica, UNAM, Cuernavaca, 1996.

Verani, Hugo, sel. y pról., La hoguera y el viento: José Emilio Pacheco ante la crítica, Era, México, 1993.

VILLEGAS, Juan, Estructuras miticas y arquetípicas en el "Canto general» de Neruda, Planeta, Barcelona, 1976.

VON DEM Bussche, Gastón, "Visión de una poesía», Anales de la Universidad de Chile, 106, 1957, 176-194.

White, JR., Lynn, «The Historical Roots of Our Ecologic Crisis», en Cheryll Glotfelty y Harold Fromm (eds.), The Ecocriticism Reader, University of Georgia Press, Atenas, 1996, 3-14.

White, Steven F., El mundo más que humano en la poesía de Pablo Antonio Cuadra: un estudio ecocrítico, Asociación Pablo Antonio Cuadra, Managua, 2002.

Williams, Raymond, The Country and the City, The Hogarth Press, Londres, 1985.

Zerán, Faride, Al pie de la letra: Entrevistas de fin de siglo, Grijalbo, Santiago, 1995. 


\section{ÍNDICE}

CAPÍTULO 1. DESDE EL ECOLOGISMO HACIA UNA ECOCRÍTICA ……………………………………..... 9

El hombre contra los bosques .............................................. 9

Nace el ecologismo ........................................................... 11

El ecologismo en Latinoamérica............................................ 13

La ecocrítica: ¿otra moda más en las aulas?.............................. 16

Atrapado en una red: el adelgazamiento del yo ....................... 18

El lugar de la tradición o la tradición del lugar ........................ 18

El lugar sacralizado: un regreso a la Edad de Oro..................... 22

En busca de la Armonía ........................................................... 26

La respuesta indígena, los ecoteólogos y el ecofeminismo......... 28

Apocalypse Now y la conciencia tóxica …............................... 31

La ecocrítica en Hispanoamérica............................................. 34

CAPÍTULO 2. CRIATURAS DEL DESARRAIGO, O EN BUSCA DE LOS LUGARES PERDIDOS: ALIENACIÓN Y ECOLOGÍA EN LA POESÍA HISPANOAMERICANA ...... 37

El desarraigo de los decadentes: de Huysmans a Julián del Casal

El desarraigo creacionista de Vicente Huidobro ...................... 44

Lenguajes universales y lenguajes arraigados (Gabriela Mistral, Jorge Teillier)....................................................................... 48

Topónimos en la poesía (Pablo Neruda, María Mercedes Carranza)

El sentido de arraigo (Ernesto Cardenal, José Emilio Pacheco). 63 ¿Conclusión? 
CAPÍTULO 3. DEL PÁJARO SIMBÓLICO AL PÁJARO REAL:

EL DESCUBRIMIENTO DEL (NUEVO) MUNDO Y EL ADVENIMIENTO DE LA ECOLOGÍA EN LA POESÍA DE NERUDA

Entre la tradición poética y la realidad: la naturaleza en Veinte poemas y Residencia en la tierra.

La armonía de la Tierra americana y sus hijos ........................ 81

Imperialismo ecológico en Canto general................................ 85

Crímenes ecológicos en el siglo XX

CAPÍTULO 4. EL DESPERTAR AMERICANO DE GAIA: ECOLOGISMO, ECOFEMINISMO Y TRADICIONALISMO EN GABRIELA MISTRAL

La Diosa redescubierta

La hipótesis de Lovelock 95

Ecofeminismo

Conversaciones sobre la tierra: el telurismo de Gabriela Mistral 100

La Gea americana 101

La maternidad omnipresente. 106

Ecofeminismo y tradicionalismo 108

CAPÍTULO 5. INDICIOS DEL FIN EN LA POESÍA MEXICANA. JOSÉ EMILIO PACHECO: ENTRE EL APOCALIPSIS Y LA CATÁSTROFE

Quinientos años de degradación ecológica.

José Emilio Pacheco: fugacidad, sufrimiento y metapoesía.

La impronta moderna: aceleración de lo fugaz, proliferación del dolor

Crisis ecológica y la fractura de las analogías

El reino de la ironía

Poesía apocalíptica y catastrofista: ¿en busca de un nuevo mundo?....

Malpaís: los estertores de México D.F. 
CAPÍTULO 6. NOSTALGIA Y MILITANCIA EN HOMERO ARIDJIS: LA ESCRITURA EN UN MUNDO POLUTO .... 133

El esplendor de la naturaleza.................................................. 133

La pérdida del esplendor ..................................................... 135

Una poética despojada de sus raíces. Entre la ironía, la elegía y el silencio

Epílogo: las novelas apocalípticas

CAPÍTULO 7. LA COMICIDAD ECOPOÉTICA DE NICANOR PARRA

La naturaleza en la poesía popular de Parra............................ 150

No hay vuelta atrás ............................................................. 151

Contra la polarización: ni socialista ni capitalista / sino todo lo contrario

¿Soluciones de parche o ecología utópica? ............................... 159

Entre la agresión, el didactismo y la arenga política ................ 162

Pichanga: la ecopoesía cantada ............................................. 165

La verdadera seriedad es cómica... y ecológica ........................ 167 

Este libro se terminó de imprimir en los talleres gráficos de Litocián, s.l. de Zaragoza,

el día 22 de marzo de 2004

$$
25
$$


a vastedad de la naturaleza americana ha dejado huellas poderosas en su literatura. No sorprende, por tanto, que los poetas de Hispanoamérica hayan sido particularmente sensibles al despertar de una conciencia ecológica, cuestionando y lamentando el creciente desarraigo de la sociedad, la formación descontrolada de espacios urbanos ecológicamente insostenibles y la contaminación de la tierra, del aire, de los ríos y de los mares.

El deterioro ecológico ha dejado su impronta no sólo en la poesía sino también en la mirada de sus lectores. En años recientes ha surgido una ecocrítica que busca métodos y enfoques interdisciplinares capaces de compaginar la critica literaria con la conciencia de la precariedad de los ecosistemas y del papel casi siempre dañino, aunque en escasas ocasiones reparador, que dentro de ellos desempeña el ser humano -y el escritor-. ¿Cómo se relaciona el sujeto poético con su entorno? ¿Hasta qué punto comparte la bybris moderna de creerse amo y señor del mundo, legitimado para explotar la tierra a su antojo? ¿Cuáles son las huellas textuales del desarraigo? ¿La tala de los bosques implica una correlativa deforestación cultural? ¿Implica el antropocentrismo moderno más que nada un androcentrismo, en su sometimiento simultáneo de la tierra y la mujer (portadora de una sabiduría telúrica)? ¿Existe también una contaminación del lenguaje, una corrosión interior de símbolos poéticos (mar-tierra-aire) que se creian intemporales?

Este estudio ofrece una lectura ecocritica de varios poetas hispanoamericanos -entre ellos Pablo Neruda, Gabriela Mistral, José Emilio Pacheco, Homero Aridjis, Nicanor Parra y Ernesto Cardenal- que se han adentrado, en busca de salidas, en el callejón de la crisis ecológica.
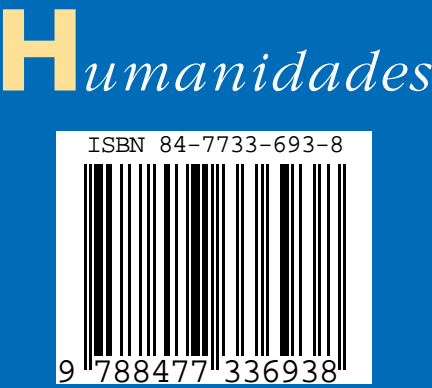